Ben Dorfman (ed.)

\title{
Dissent! Refracted
}

Histories, Aesthetics and Cultures of Dissent

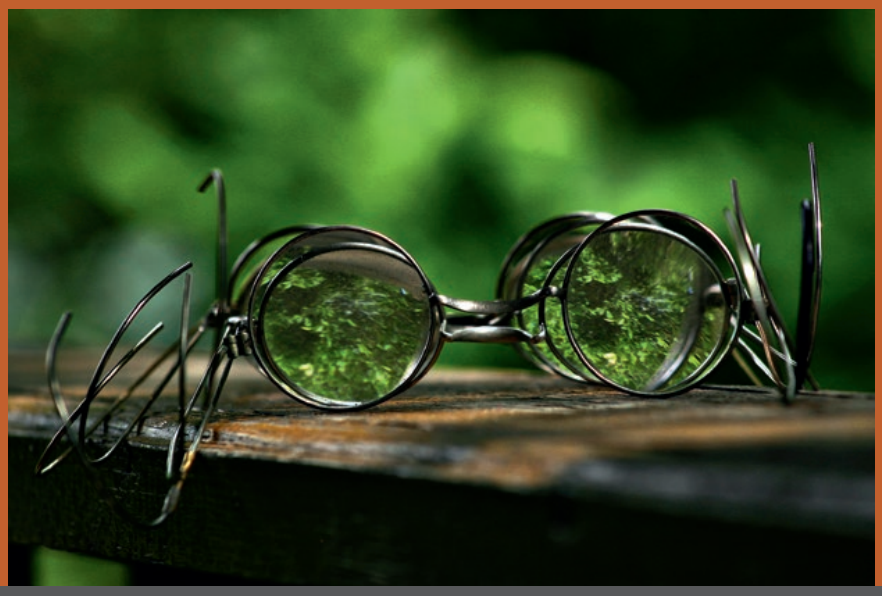




\section{Ben Dorfman (ed.)}

\section{Dissent! Refracted}

This collection of essays addresses the ongoing problem of dissent from a broad range of disciplinary perspectives: political philosophy, intellectual history, literary studies, aesthetics, architectural history and conceptualizations of the political past. Taking a global perspective, the volume examines the history of dissent both inside and outside the West, through events in the twentieth and twenty-first centuries both nearer to our own times as well as more distant, and through a range of styles reflecting how contested and pressing the problem of dissent in fact is. Drawing on a range of authors and international problematics, the contributions discuss the multiple ways in which we refract memories of dissent in cultural, historical and aesthetic context. It also discusses the diverse ideas, images and phenomena we use to do so.

\section{The Editor}

Ben Dorfman is Associate Professor of Intellectual and Cultural History at the Department of Culture and Global Studies, Aalborg University (Denmark). 
Dissent! Refracted 


\title{
POLITICAL AND SOCIAL CHANGE
}

\author{
Edited by Martin Bak Jørgensen and Óscar García Agustín
}

\section{VOLUME 3}

Zu Qualitätssicherung und Peer Review der vorliegenden Publikation

Die Qualität der in dieser Reihe erscheinenden Arbeiten wird vor der Publikation durch einen Herausgeber der Reihe sowie durch einen externen, von der Herausgeberschaft ernannten Gutachter im Blind-Verfahren geprüft. Dabei ist der Autor der Arbeit dem Gutachter während der Prüfung namentlich nicht bekannt.
Notes on the quality assurance and peer review of this publication

Prior to publication, the quality of the work published in this series is reviewed by one of the editors of the series and blind reviewed by an external referee appointed by the editorship. The referee is not aware of the author's name when performing the review. 
Ben Dorfman (ed.)

\section{Dissent! Refracted}

Histories, Aesthetics and Cultures of Dissent 


\section{Bibliographic Information published by the Deutsche}

The Deutsche Nationalbibliothek lists this publication in the Deutsche Nationalbibliografie; detailed bibliographic data is available in the internet at http://dnb.d-nb.de.

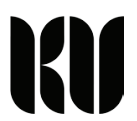

An electronic version of this book is freely available, thanks to the support of libraries working with Knowledge Unlatched. KU is a collaborative initiative designed to make high quality books Open Access for the public good. More information about the initiative and links to the Open Access version can be found at www. knowledgeunlatched.org.

Open Access: The online version of this publication is published on www.peterlang.com and www.econstor.eu under the international Creative Commons License CC-BY-NC-ND 4.0. Learn more on how you can use and share this work: https://creativecommons.org/licenses/by-nc-nd/4.0/.

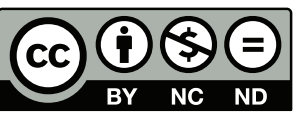

All versions of this work may contain content reproduced under license from third parties. Permission to reproduce this third-party content must be obtained from these third-parties directly.

\section{Library of Congress Cataloging-in-Publication Data}

Names: Dorfman, Ben, editor.

Title: Dissent! Refracted : histories, aesthetics and cultures of dissent /

Ben Dorfman (ed.).

Description: 1 Edition. | New York : Peter Lang, 2016. | Series:

Political and social change; Volume 3

Identifiers: LCCN 2016005555 | ISBN 9783631673737

Subjects: LCSH: Dissenters. | Government, Resistance to.

Classification: LCC JC328.3 .D583 2016 | DDC 306.2-dc23

LC record available at http://lccn.loc.gov/2016005555

Cover Image:

freeimages.com/Griszka Niewiadomski.

ISSN 2198-8595

ISBN 978-3-631-67373-7 (Print)

E-ISBN 978-3-653-06629-6 (E-Book)

DOI 10.3726/978-3-653-06629-6

(c) Peter Lang $\mathrm{GmbH}$

Internationaler Verlag der Wissenschaften

Frankfurt am Main 2016

Peter Lang Edition is an Imprint of Peter Lang GmbH.

Peter Lang - Frankfurt am Main · Bern · Bruxelles · New York ·

Oxford $\cdot$ Warszawa $\cdot$ Wien

This publication has been peer reviewed.

www.peterlang.com 
Has there ever been a society which has died of dissent? Several have died of conformity in our time.

Jacob Bronowski 



\section{Acknowledgements}

This book is a result of the conference "Dissent: Histories and Meanings of Opposition Since 1968," held January $16^{\text {th }}-17^{\text {th }}, 2014$ at Aalborg University in Denmark. The conference was multidisciplinary, incorporating historians, philosophers, sociologists, political scientists, cultural studies scholars, critical theorists, literary scholars, art historians, architecture scholars, and activists. The conference addressed problems of resistance, opposition, and social change from perspectives contemporary and historical as well as theoretical and empirical in nature. This is the second of two volumes from the conference. The first, The Politics of Dissent (Óscar Garcia Agustín and Martin Bak Jørgensen, eds.), addresses contemporary dissent movements. This volume picks up on further themes of aesthetics, memory, intellectual history, representation, senses of time and problems of history. Combined, the volumes should take readers to multiple locales in the field of dissent, offering present-day as well as historically-based critiques.

Neither the conference volumes nor the conference itself would have been possible without Óscar Garcia Agustín's and Martin Bak Jørgensen’s work as coorganizers, nor that of Sandro Nickel, our other co-organizer. Óscar and Martin's work as editors of the series in which the volumes appear has also been invaluable.

In addition to the series editors and the conference's organizers, I'd like to express my thanks to the Department of Culture and Global Studies and the Faculty of Humanities at Aalborg University. Both provided invaluable support for this project, and Department Chair Marianne Rostgaard deserves particular appreciation for her interest in the work. I should also thank Patrick Thomas Casey, copyeditor and style commentator for the project, for his close attention to detail. The work benefitted greatly from his engagement.

Of course, no investigative or expressive act is arrived at without the influence of others. For the many friends, family and colleagues contributing to my intellectual development, I am grateful. I offer special thanks to my parents, Eve Kenyon and Bruce Dorfman, for imbuing me, each in their own way, with a spirit of dissent.

Ben Dorfman Aalborg, June 2015 



\section{Contents}

Ben Dorfman

Refractions: Dissent and Memory

Barbara J. Falk

The History, Paradoxes, and Utility of Dissent: From State to Global Action

Barbara Martin

History as Dissent: Independent Historians in the Late Soviet Era

and Post-Soviet Russia: From "Pamiat" to "Memorial".

Bent Sørensen

Dissent as Race War: The Strange Case of Amiri Baraka.

Hasmet M. Uluorta

The Tea Party: An Ethical All-American Performance

Stephanie Sapiie

Intellectual Identity and Student Dissent in Indonesia in the 1970s

Janina Gosseye \& John Macarthur

Angry Young Architects: Counterculture and the

Critique of Modernism in Brisbane, 1967-1972.

Verita Sriratana

"But That is Perhaps Why I Can Talk of Where I Want to be

Without Always Being Dragged Back to My Starting Point”:

Rethinking and $\operatorname{Re}(-)$ Membering Czech and Slovak Histories

of Violence and Dissidence through the Historical "Infranovel"

Ben Dorfman

Intellectuals and Dissent: Dennis Rodman, Memory Refractor

Kalle Pihlainen

Jean-Paul Sartre and the Post-1968 Ethic of Anti-Representationalism

Contributors 



\section{Ben Dorfman}

\section{Refractions: Dissent and Memory}

\section{By Way of Introduction...}

Ours hasn't been the only good time to write about dissent. The concept has broken like waves across Western history-1215, 1517, 1642, 1776, 1789, 1830, 1848, 1871, 1917, 1968, 1989 are all dates incomprehensible without the "no." In his well-known "Ten Theses on Politics," e.g., Jacques Rancière $(2010,42)$ notes dissensus - a related yet distinct concept - as "the manifestation of a distance of the sensible from itself." Stephen Corcoran $(2010,2)$, interpreting Rancière's work, suggests dissensus as not the "institutional overturning" we'd usually expect, but "an activity [cutting] across forms of cultural and identity belonging and hierarchies between discourses and genres." It's a mouthful. Still, Corcoran might be right: dissensus brings new identities and ideas into historical space. Dissensus elucidates "new subjects and heterogeneous objects" and their function on the "field of perception" (Corcoran 2010,2). Whether it's politically limited monarchs, Protestantism qua religious movement, democracy as the basis for the state, the beginnings or ends of socialism or the development of counter-cultural movements, it's clear that meaningful social phenomena and groundbreaking ideas have been products of dissent. As Rancière argues, processes of negotiating difference over time bring irruptions into the historical fabric; things take different directions than they otherwise would. I-we- keep the " $t$ " in "dissent," however, to remove senses of temporality ("dissensus" as opposed to "consensus," somehow-elongated processes of negotiation). Dissent is a moment; an act. It's a putting up of a hand and stopping things in their tracks. Legal scholar Cass Sunstein (2003) has posed dissent as not always "doing what others do." It seems to me, anyway, to be a good place to start.

Recent years have been filled with dissent. Generation X'ers will find it hard not to remember the dramatic events of the late ' 80 s and early ' 90 s. Momentum built slowly: Soviet dissidents in the '60s and '70s, movements like Charter 77, Poland's Solidarity, and intellectuals based around journals like the Hungarian Demokrata. These challenged the solidity of Eastern regimes that, truth be told, may never have been as solid as they might have either liked or seemed. 1989 broke like water through a dam, though - a tide flow of happenings washing over and under authoritarianism's gates, begging for the renewal of systems whose foundations had become arid ground. From protestors on both sides of 
the Berlin Wall shouting "Die Mauer muss weg!" to demonstrators jingling keys on Prague's Wenceslas Square to the hissing down of Ceausescu in Bucharest's Palace Square - to say nothing of events in China in the spring of that year-it was hard not to be impressed by the "no" leveled at ranges of monolithic regimes both within the West and without. The barricades in front of the Russian parliament in the summer of ' 91 may have been a capstone - the violent end to a form of politics ("real existing socialism") born out of opposition (to capitalism) yet which came to quell opposition as much as it supported it in its supposed opposition to a capitalistically mind washed mainstream. Meanings were unclear. Was communism a "defective form of recognition," as Francis Fukuyama (1992, xix) posed it? Were regimes founded in radical critique destined for totalitarian ends? Perhaps so. Still, the late 1980s and early 1990s demonstrated that people could bring change. That was regardless of the state, set of ideas, or particular political system against which people might pose themselves.

In many ways, these halcyon days unfortunately evaporated quickly. Postmodern malaise set in, and at least some have claimed we moved quickly towards cultures of apathy (Jacoby 1999; Jameson 1991). ${ }^{1}$ More than a few commentators have noted that the remaking of the "world order" (Huntington 1996) involved senses that the battles of dissent had been won. Opposition seemed to have done its chore and neo-liberal values simply became "correct" (Hobsbawm 1990). Of course one could choose between more laissez-faire American models and more social-democratic European approaches: the "third way," as Anthony Giddens (1998) phrased it—capitalism with a human face-was open to more than one interpretation. Still, one could rest. The barricades could come down. In the name of any ideology, there would be scant reason they should be put up again.

Still, dissent persisted. "Globalization" became a new locus of critique and the "Battle in Seattle" (1999) brought demonstrable levels of political conflict to the homeland of the Pax Americana. That's while protests from Genoa to Göteborg in 2001 - the early days of "altermodernity" (Hardt and Negri 2009) — marked the fact that not everyone accepted the new modes of socio-political management. Flows of borderless finance, multi- and international monetary institutions (the WTO, IMF and World Bank, primarily), senses that neo-liberal ideas should rule the roost unchecked and often opaque networks of global political power gained question-radically so (Zweifel 2006; Thompson 2010). The focus was on anything not conforming to "democratic norms" or offering itself to popular review (Teivainen 2008, 174). Still, an even greater wave of protests lay on the horizon.

1 Jameson's $(1991,6)$ precise vocabulary is "depthlessness." 
Here, I point to everything from Occupy to phenomena like Spain's Indignados to Brazil's Revolta da Vacina to anti-austerity movements almost anywhere austerity set in (see Agustín and Jørgensen 2015). Between the first wave of globalizationskeptical protests and a second, we gained an early twenty-first century interrogation of whether we had things arranged the way we ("we" - a global polity) wanted. Swathes of interlaced movements asked if global society had established socio-economic systems it not only took as just, but which were just in more than just the subjective sense of whether one imagines them to be or not. ${ }^{2}$

Now, regarding the more recent of these movements, Indignados, Occupy, and Revolta and other iterations of recent movements petitioning for social justice, financial crisis played a significant role. The 2007-8 burst of the American housing bubble depressed the world economy and brought hardship virtually everywhere the flows global finance went. This made income disparity and "fat cats" hot topics in Europe, America and many places beyond (Taibbi 2014; della Porta 2015 [indeed, "fat cats" and income disparity are major themes in the current American election cycle (Gearan 2015; Chozick 2015)]). More than economics mark what might be thought of as a second wave of early twenty-first century dissent, however. The world was wowed by the Arab Spring and Middle East protests between 2010 and 2013, e.g., as, from Tunisia to Egypt to Syria, discontent with the state of civil liberties, the entrenchment of dictatorial regimes but also, curiously, the desire to advance varieties of religious perspectives ("fundamentalism" is the easier word) brought down some regimes, caused self-reflection in others, and engendered still-unresolved civil wars in yet more (Lesch and Haas 2012; Moaddel and Karabenick 2013). Clearly, there are debates over the meaning of events like 9/11 or the bombings in London and Madrid; events marking the turn into the new century. There are similarly important discussions concerning the recent murder of cartoonists and editors at Charlie Hebdo and the attempted assassination in Copenhagen of Swedish illustrator Lars Vilks. ${ }^{3}$ Such events reveal a civilizational clash that is more than skin deep. When forces clash, however, implicit is always a "no." Distasteful though we might find certain modes of

2 Here, I point to justice not only as a matter of consent-a Rawlsian discussion-but an absolute meeting of human needs whether societies agree on those needs or not. See Rawls (1971); Boylan (2004).

3 George Packer (2015) in The New Yorker argued that the Charlie Hebdo killers were "soldiers in a war against freedom of thought and expression" driven essentially by power-thirsty ideologies. Gary Young (2015) in The Guardian, however, has wondered whether larger, global social currents contribute to the social polarization leading to extremist activity. They dissent, somehow, against each other's dissenting views. 
expression-and when it comes to the killing and threatening of artists and illustrators, distasteful they are-somebody is saying they don't like something. Indeed, somebody has indicated that they're not satisfied with the current conditions of global power. As Tom Rockmore $(2011,108)$ has put it, the push back against the West fits into a triangulation of mindsets-anti-colonialism, antiimperialism and anti-Americanism - with significant presence in the second half of the twentieth century (see also Tibi 2002). Of course, those forms of dissent have garnered dissent themselves. The demonstrations against the Charlie Hebdo killings are an example. Political leaders and broad populaces struck back against religio-political violence; demonstrations were broad and counter voices clear. Dissent, it seems, emerges where power flows. Dissent characterizes disputes over norms, worldviews and their institutionalization. That's even when worldviews are undergirded by the means to defend them and it's posited that it's dangerous if we don't. I.e., dissent can involve opposition to entrenched global power, but also its securitization as well. ${ }^{4}$

One could go on ad infinitum about recent sites of dissent. Sometimes, dissent is worn as a badge. Dissent becomes a sit of memorialization - that whether we discuss the heroes of civil rights, the pioneers of women's liberation or those risking all to fight Apartheid and the oppression of the poor (figures from Martin Luther King to Emmaline Pankhurst to Nelson Mandela to Cesar Chavez would be examples). Figures like Malala Yousafzai have become global celebrities protesting cultures of gender oppression in the developing world (Chozick 2015; Doeden 2015); voices such as Avijit Roy's have challenged us to broaden senses of the free speech/“clash of civilizations" paradigm beyond the "West" versus the "rest" (i.e., conflicts can be specific, regional and local as well [Dorfman 2016]). Potentially, one can dissent in silence. For example, if-if-we accept the 9/11 attacks, gruesome as they were, as a mode of protest, much of that was done quietly. Preparation was massive and covert. Years of subtle planning were involved. A flame of anger had to be long-stoked to create what may have been the early twenty-first century's defining event (Zarembka 2011; Calvert 2010). Still, results had to be seen. Statements had to be made. Voices of dissent needed to be heard and sights of it encountered. Concepts had to resonate and marks needed to be made in space and time. Dissent always has to pull its head over the surface and become known.

4 As Corey Robin (2011) puts it, dissent can be attached to the "reactionary mind": postures in fact defending entrenched interests, yet posing themselves as outside the maintstream in the attempt to inclulcate senses of threat, or, in fact, believing threats exist to values one in fact seeks to defend. 
We're thus confronted with consciousness of dissent. We're confronted with knowing dissent: auralizing it, visualizing it, addressing it; contemplating its presentation and forms. We're confronted by dissent's figuration-how dissent is put together, its modes of reception and knowledge about it cycles. Dissent winds through imaginations and plays in our views. Again, we know this. National narratives are formed around the importance of dissent. Every national independence is formed for "us" and against "others" (others often assumed to have the dominant position against which one dissents [de Buitrago 2012]). Constitutions have been born out of dissent-American and French democracy are primary examples of this. Democratic systems are built around and experience dissent themselves. That's as voice and counter-voice are part of liberal systems (see Rawls 1993), yet sometimes some wonder if liberal systems are what constitutes the best politics for all. "It's dangerous to be right in matters in which established authorities are wrong," Voltaire once said (1779, lxxxiii). Such are the sentiments infusing acts of "not doing what the others do." That's whether such acts are contemporary or historical, easy to see or, from time to time, demanding a bit more squinting so one can discern what's being dissented against, or the many fine dots on the global fabric where dissent is taking place.

We thus need to refract dissent. We have to see it and play with it like glass in a kaleidoscope or binoculars training on a ship we see from afar. We have to turn dissent into memory, engaging it as a practice playing out in a wide variety of locales, through many concepts and in accordance with an array of scripts. Dissent brings stories from multiple angles with few geographical bounds and out of multifarious socio-cultural traditions. Dissent can encompass American Tea Partiers decrying what they see as Washington's betrayal of libertarian principles-a supposed homage to the foundations of the republic yet expression of discontent with senses of franchise now. Dissent can include poet-artistes like Amiri Baraka angling against structures of racism any way they can. Dissent can be reproductions of censored publications, such as the samizdat of the Soviet Union and Eastern Bloc states, circulating quietly yet always in danger of capture and destruction. Dissent can include "angry young architects" and the countercultural postures of youth and intellectualism in Queensland universities in late 1960s and early 1970s. Dissent questions "existential" sensibilities, such as the conceptualization of opposition in literary and philosophical oeuvres like Jean-Paul Sartre's. Dissent includes the handling of resistance narratives such as those surrounding "Operation Anthropoid" - the action that killed Reinhard Heydrich in Czechoslovakia in 1942. As an issue, dissent can shine through in our expectation that public figures engaging international politics will play the role of sage-like intellectuals-that 
while we sometimes revile those engaged with the edges of critical thought at any rate. Dissent can support dictatorial regimes and oppose them, as happened with student dissent in Indonesia in the 1960s and '70s.

This book engages all of these issues and more. A selection of papers from a 2014 conference, Dissent! Refracted involves broad senses of how diverse the world of not "doing like the others" both can be and is. The current volume incorporates some of dissent's headline themes-dissidence in the now-defunct socialist world, the dissenting philosopher and the memory of reactions to Zeitgeist-defining upheavals such as the cultural battles of the ' 60 s and '70s, e.g. The book also strays from more-discussed paths, investigating the diverse sites and multiple modes of memory involved in not only in the recollection of dissident "no's," but understanding the processes of institutionalization and memorialization of the "no's" that have often come from our lips. This book is not a theoretical treatise. It presents views of dissent and varieties of its historical, cultural and philosophical refraction (i.e., it largely analyses different dissenting situations). Still, in accepting a wide range of politicized, counter-cultural, non-conformist, anti-imperialist, minority vocalizations and anti-hegemonic acts as part of not "doing what the others do," it offers a range of views on what dissent might be. Terry Eagleton (2003, 263) notes that one needn't be "besieged on all sides" to dissent. Powerful institutions and individuals can pose themselves as "dissenters" as much as minorities and outsiders. Still, dissent hovers over us as a figure-an idea, desire, and a want many of us engage. That's at the same time we're not always exactly sure how, or even why, we feel the urge to dissent that it often appears we do.

The first essay in this book, "The History, Utility, and Paradoxes of Dissent: From State to Global Action," by Barbara Falk, perhaps serves as a better introduction to the issue than has been provided here. Based on her wide-ranging scholarship in history, political theory, and international politics, Falk takes a broad view of dissent, moving through historical and contemporary instances of dissent's articulation and consideration. With stylistic clarity, Falk offers the view that there's no such thing as an uncritical view of dissent. Every oppositional action deserves to be critiqued as much as the objects of dissent themselves. This offers dissent as a multi-sided, open ended affair. It's fecund; dissent feeds off itself and demands we challenge expectations. In the end, though, Falk sides with Hannah Arendt. Politics isn't a separate sphere of life. Politics is life. Life can't breathe without the necessary oxygen of dissent and free thought. Falk offers broad insight into the multiple pathways dissent has taken in relation to a range of issues both familiar and unique, close to our own times as well as distant from the historical spaces we often consider our own. 
The next essay, Barbara Martin's "History as Dissent: Independent Historians in the Late Soviet Era and Post-Soviet Russia: From 'Pamiat" to "Memorial'" picks up an issue likely both familiar and unfamiliar to general readers: the question of dissident historians in the Soviet Union. The trope of dissenting intellectuals in the USSR in the second half of the twentieth century is familiar. It's a central part of Cold War narratives-oppressive socialist systems and unconventional thinkers yearning to be free. What may be less-known is the specific figure of the historian. The mid- to late-Cold War USSR represented an era rich in dissent; from Solzhenitsyn to Sakharov to the "refuseniks." The 1960s, '70s and ' 80 s provided headline names for global rights and the need for diverse thought. Martin, however, confronts an issue that has only begun to gain momentum: the fate of historians as indicative of countries' relation with political memory. Addressing Pamiat' and Memorial-the former a publication, the latter an organizationMartin articulates notions of legacy and public discourse central to this book.

The third essay, Bent Sørensen's "Dissent as Race War: The Strange Case of Amiri Baraka," addresses a similar period-the middle to late twentieth century. Sørensen shifts the scenery to America, however, where questions of what it meant to resist, perhaps especially for the Afro-American community, persist and continue to be asked. Baraka-LeRoi Jones in his first manifestation-was a controversial figure. The creator of the Black Arts Movement and author of controversial works such as Dutchman (1964), Baraka’s career reads like a résumé of the travails and victories of Black radicalism - challenging race conventions, teetering off the beaten path sometimes towards the offensive and sometimes coming home to more "acceptable" politics; all the while asking what those politics may be. Baraka's was a life spent challenging the boundaries of the society that surrounded him, yet reconciling with those boundaries as well. Sørensen deals with all of this. Baraka, Sørensen suggests, was the dissenter: the necessity of critique was Baraka's raison d'être and the primary lens through which he should be read. It's a point Sørensen tells us we shouldn't forget as race continues to be a central American issue even as memories of Baraka specifically might begin to fade.

The book stays in the U.S. with Hasmet Uluorta's "The Tea Party: An Ethical All-American Performance." Two points are worth noting here. First, dissent is not only "left-wing." Conservative appeals to the "nation" can be dissent, or at least be posed as such. Secondly, dissent involves psychological structures. Using a Lacanian analysis, Uluorta suggests Tea Partiers establish an "ethical AllAmerican": a point of irrefutable appeal intended to overcome general problems with identification and social belonging central to general publics regardless of their politics and how they're posed. It's a complex yet relevant thesis addressing 
battles for mainstream norms. Today, these battles dominate ongoing discussions in the U.S. media and public as electoral pluralities work through the turmoil of both their representative bodies and electoral cycles in which they will soon again decide on a head of state.

The book stays on the terrain of what might be posed as "non-traditional" histories of dissent with Stephanie Sapiie's "Intellectual Identity and Student Dissent in Indonesia in the 1970s." Sapiie takes us to a little discussed locale, at least for many Western audiences, in the boilerplate of Indonesian politics during the transformational period of the '60s and '70s. Again, we see an emphasis on the fact that dissent can emerge from more than just the left. As in Uluorta's piece, nationalists - conservative nationalists-are loci of dissent. On one hand, Sapiie argues, anti-Communism informed the early activism of student dissenters in Indonesia in the 1960s. However, there came a focus on intellectual production as the center of political discourse and activist expression. In this context, the Suharto regime tried to control dissenters as much as support them-support being an early key to the regime's success. The complexities of dissent and its relations with the state, Sapiie argues, bears remembrance in our own time.

For pieces five and six, we branch off into two further articles considering dissent from quite different angles. In "Angry Young Architects: Counterculture and the Critique of Modernism in Brisbane, 1967-1972," Janina Gosseye and John Macarthur narrate the experience of a specific example of the countercultural world in its salad days in the 1960s and '70s: architectural students from Australia's University of Queensland and their debates over aesthetics, politics, and the intersections between the two. This examples introduces an unusual dissent narrative. That's not in the sense that art and design students might be caught up in counterculture. Such things were hardly unheard of in the years of "tune in, turn on and drop out." It's more in the sense of framing political ideas within the considerations of aesthetic theory and the challenges to artistic convention occurring in countercultural forms important to the history of the late twentieth century. Through Gosseye and Macarthur's work, we understand a specific moment of dissent in a crucial era for the concept. We gain a sense of how the macrocosm of late-' 60 s and early-'70s counterculture manifested itself in more microcosmic senses.

Verita Sriratana, in her essay "'But That is Perhaps Why I Can Talk of Where I Want to be Without Always Being Dragged Back to My Starting Point': Rethinking and $\operatorname{Re}(-)$ Membering Czech and Slovak Histories of Violence and Dissidence through the Historical 'Infranovel,' also picks up on aesthetic issues. Sriratana addresses the representation and narrativization of dissent in relation to a quite different problem, however: Operation Anthropoid, or the Czech assassination 
of Heydrich. That's as discussed in Larent Binet's novel $H H h H$ (2010). $H H h H$ provides an account of the assassination interspersed with observations of the author's subjective writing and research processes. Sriratana makes several important points. Yes, dissent comes through political action. Though bringing massive reprisals, Heydrich's assassination was an important blow in the European-wide resistance to Nazi rule. There is no dissent without representation, however, and the narrative forms of dissent's depiction need to be thought through as carefully as anything else associated with the act. Binet's novel, and Sriratana's treatment of it, directly addresses such issues.

"Intellectuals and Dissent: Dennis Rodman, Memory Refractor," written by the current author, is this book's eighth essay, and it moves in different directions. Blending scholarship with feuilleton, this piece addresses the case of former American basketball star Dennis Rodman on his recent visits to North Korea. A bizarre affair, the issue butts against the themes of this book in two ways. First, the history of the intellectual, from Voltaire on, is decidedly bound to notions of dissent. Critique is expected as part of the intellectual's purview and, strangely enough, "intellectual" is what it seems many wanted Rodman to be-a social commentator "properly" involved in world affairs. It's an expectation he would disappoint. Secondly, in our expectations of him, the controversy around Rodman's North Korea visit evokes ghosts and names from times when politics, ideology and social philosophy was the stuff of mortal combat and positions on such things were popularly expected and mattered. Those are times problematizing the morality of dissent and what to do when we see the sunbeam of "intellectual dissent" past, yet it's bent to the left or right, as all beams of light necessarily are. Rodman becomes a strange locale for sensing history among us, yet, or simultaneously, asking what it is we want our historical figures to be.

The book concludes with Kalle Pihlainen's essay "Jean-Paul Sartre and the Post1968 Ethic of Anti-Representationalism.” Here, Pihlainen takes us onto the intellectual terrain of one of the twentieth century's great dissidents: Sartre, perhaps the grand don of "no" in the name of liberation and the intoxicating possibilities of counterculture. In the process of remembering dissent, Pihlainen argues, we again remember how closely the act is bound to intellectual figures and philosophical thoughtways. Dissent is the narrative we think it is; it's the romance of the radical against the machine. Pihlainen, however, describing a particular break in the history of Sartre's thought, makes the provocative claim that absconding ideologies of representation and what he characterizes as "representational violence" (insisting on decidability when one need not) is in fact the terrain of a true politics of dissent. We can tell a great number of histories of dissent: social, political and cultural. 
Pihlainen, however, through close philosophical analysis, tells both an intellectual and aesthetic history. Focusing on Sartre's study of Flaubert, Pihlainen shows how one of the ultimate figures in modern oppositional thought may have rethought his own concept of oppositional ideals. With that, Pihlainen challenges not only the ways we think about Sartre, but the established concepts of dissent embodied in broad sectors of a towering intellectual's oeuvre.

Again, this book addresses a diverse array of issues. Its essays span intellectual history, political history, social history, architectural history, literary aesthetics, and philosophical investigation. Dissent! Refracted's pieces work through novels, cultural commentary, archival work, policy analysis, and theoretical investigation. They theorize without always being explicitly theoretical and, without being explicitly theoretical, they theorize. What emerges is that regardless of where one looks on historical bases as well as in times we might call our own, dissent has presence. Dissent has a life. Dissent sparkles, shooting across the gaps of history like sunbeam refractions filling the space around us. Dissent comes to us like shades of color emerging from the far side of a crystal. That crystal, of course, is the distance time provides between ourselves and the historical past; it's the distance between those of us who did and the acts of those of us who will. That's whatever our will, and any "no's" we might use to articulate it, turn out to be.

\section{References}

Agustín, Óscar Garcia and Martin Jørgensen, eds. 2015. Politics of Dissent. Frankfurt am Main: Peter Lang.

Boylan, Michael. 2004. A Just Society. Lanham: Rowman \& Littlefield.

Brown-Nagin, Tomiko. 2011. Courage to Dissent: Atlanta and the Long History of the Civil Rights Movement. Oxford: Oxford University Press.

Calvert, Peter. 2010. Terrorism, Civil War, and Revolution: Revolution and International Politics. New York: Continuum.

Chozick, Amy. 2015. "Campaign Casts Hillary Clinton as the Populist It Insists She Always Has Been." The New York Times (April 21). http://www.nytimes. com/2015/04/22/us/politics/hillary-clintons-quest-to-prove-her-populistedge-is-as-strong-as-elizabeth-warrens.html.

Corcoran, Steven. 2010. "Editor's Introduction." In Dissensus: On Politics and Aesthetics, ed. Steven Corcoran, 1-25. New York: Continuum.

de Buitrago, Sybille Reinke, ed. 2012. Portraying the Other in International Relations: Cases of Othering, Their Dynamics, and Potential for Transformation. Newcastle upon Tyne: Cambridge Scholars. 
della Porta, Donatella. 2015. Social Movements in the Time of Austerity: Bringing Capitalism back into Protest Analysis. Cambridge: Polity.

Doeden, Matt. 2015. Malala Yousafzai: Shot by the Taliban, Still Fighting for Equal Education. Minneapolis: Lerner.

Dorfman, Ben. 2016 (forthcoming). "The Clash of Civilizations, Sub-Continent Style." In Opinions and Interventions: 13 Acts of Academic Journalism and Historical Commentary on Human Rights. Frankfurt am Main: Peter Lang.

Eagleton, Terry. 2003. Figures of Dissent: Reviewing Fish, Spivak, Žižek and Others. London: Verso.

Fukuyama, Francis. 1992. The End of History and the Last Man. New York: Penguin.

Gearan, Anne. 2015. 'Clinton to Middle Class: Deck is 'Stacked' to Favor the Top." The Washington Post (August 19). http://www.washingtonpost.com/ news/post-politics/wp/2015/08/19/clinton-to-middle-class-deck-is-stackedto-favor-the-top/.

Giddens, Anthony. 1998. The Third Way: The Renewal of Social Democracy. London: Polity.

Hardt, Michael and Antonio Negri. 2009. Commonwealth. Cambridge, MA: Harvard University Press.

Hobsbawm, Eric. 1990. "Goodbye to All That." Marxism Today. October: 18-23.

Huntington, Samuel. 1996. The Clash of Civilizations and the Remaking of the World Order. New York: Free Press.

Jacoby, Russell. 1999. The End of Utopia: Politics and Culture in an Age of Apathy. New York: Basic Books.

Jameson, Fredric. 1991. Postmodernism, or the Cultural Logic of Late-Capitalism. Durham, NC: Duke University Press.

Lesch, David and Mark Haas, eds. 2012. The Arab Spring: Change and Resistance in the Middle East. Boulder: Westview.

Moaddel, Mansoor and Stuart A. Karabenick. 2013. Religious Fundamentalism in the Middle East: A Cross-National, Inter-Faith, and Inter-Ethnic Analysis. Leiden: Brill.

Packer, George. 2015. “The Blame for the Charlie Hebdo Murders.” The New Yorker (January 7). http://www.newyorker.com/news/news-desk/blame-forcharlie-hebdo-murders.

Rancière, Jacques. 2010. “Ten Theses on Politics." In Dissensus: On Politics and Aesthetics, ed. Steven Corcoran, 27-44. New York: Continuum.

Rawls, John. 1993. Political Liberalism. New York: Columbia University Press.

Rawls, John. 1971. A Theory of Justice. Cambridge, MA: Harvard University Press. 
Robin, Corey. 2011. The Reactionary Mind: Conservatism from Edmund Burke to Sarah Palin. Oxford: Oxford University Press.

Rockmore, Tom. 2011. Before and After 9/11: A Philosophical Investigation of Globalization, Terror, and History. New York: Continuum.

Sunstein, Cass, R. 2003. Why Societies Need Dissent. Cambridge, MA: Harvard University Press.

Taibbi, Matt. 2014. The Divide: American Injustice in the Age of the Wealth Gap. New York: Spiegel and Grau.

Teivainen, Teivo. 2008. "Expanding the Boundaries of the Political: Globalization Protest Movements and the State." In New Perspectives on Globalization and Antiglobaization: Prospects for a New World Order?, ed. Henry Veltmeyer, 173-86. Farnham: Ashgate.

Thompson, A.K. 2010. Black Bloc, White Riot. Oakland: AK Press.

Tibi, Bassam. 2002. The Challenge of Fundamentalism: Political Islam and the New World Disorder. Berkeley: University of California Press.

Voltaire. 1779. The Age of Louis XIV. London: Fielding and Walker.

Young, Gary. 2015. "Charlie Hebdo: The Danger of Polarised Debate." The Guardian (January 11). http:/www.theguardian.com/commentisfree/2015/jan/11/ charie-hebdo-danger-polarised-debate-paris-attacks.

Zarembka, Paul. 2011. The Hidden History of 9/11. $2^{\text {nd }}$ ed. New York: Seven Stories.

Zweifel, Thomas D. 2006. International Organizations and Democracy: Accountability, Politics and Power. London: Lynne Reiner. 
Barbara J. Falk ${ }^{1}$

\title{
The History, Paradoxes, and Utility of Dissent: From State to Global Action
}

\begin{abstract}
This chapter provides a thematic introduction to the political philosophy and intellectual history of dissent, beginning with an examination of definitions, origin stories, and examples. The problematic relationship between dissent and violence is illustrated, along with a discussion of transnationality, historicity, and speed in contemporary dissent. Finally, the chapter concludes with an argument in favor of "leaderful" rather than "leaderless" movements of dissent in terms of maximizing the possibilities for effective and lasting political and social change.
\end{abstract}

Much of the politics and history of the world has been written from above. In the conventional understanding, grand programs for remaking politics and society, raw calculations of national interest, or decisions to invade territory or petition for peace all emerge from political elites. Even political ruptures and revolutions, where society overflows and renders "politics as usual" unpredictable, are often contained and described in narratives that privilege the few rather than the many. Still, it is dissenters rather than the pragmatic and status quo-oriented consensus of the powerful few that have played the most dramatic and sometimes surprising role in political, economic, and social transformation. Dissent is a double-edged sword. The mere existence and flourishing of dissent is a powerful source of legitimation in democratic societies-locales where free expression and unhindered public association are constitutionally guaranteed, highly valued, and the basis of political systems. Dissent provides, to paraphrase the words of American jurist Oliver Wendell Holmes, critical voices heard within a larger "marketplace of ideas"-alternative views and values not foreclosed (Healy 2013). This means that dissent can also be powerfully dangerous and delegitimizing, however, particularly when the object of critique is a reigning power elite or political system.

The purpose of this chapter will be to provide a thematic and by no means exhaustive introduction to the political philosophy and intellectual history of

1 The author wishes to sincerely thank Ben Dorfman and all those who worked on the Dissent! conference for the kind invitation to attend, and for encouraging me to "translate" my address into this chapter. Thanks also to Matthew Poggi and Bahar Banaei for indefatigable research assistance and for Jules B. Bloch for his usual careful scrutiny of my arguments. 
dissent. I will first look at definitions of dissent and provide a set of historical origins. Second, I will pose the contestable and recurring question of violence as necessarily part of the continuum of dissent and its repression. Third, I will look at the experience of dissidents in Central and Eastern Europe as one of the cases of successful dissent par excellence, yet with troubling features. Primary among these troubling features is who gets to be called a dissident and for what reason. It is an issue of paramount importance. Finally, I will move to a discussion of dissent today. I am especially interested in questions of transnationality, historicity, and speed. In conclusion, my meditations will leave off with some observations on the relationship of the few to the many, and the relationship between leadership and dissent.

\section{Definitions and Origins of Dissent}

The term "dissent" derives from the Latin verb dissentere; literally, to differ in sentiment. The Oxford English Dictionary (1987, vol. 1, 506) suggests a large tent of meanings, including difference of opinion or disagreement, withholding assent, as well as the action of thinking differently. In the history of political theory, dissent connotes both difference of opinion or sentiment with prevailing norms or legal-political structures, as well as disagreement with or even challenge to those norms or structures. Dissent implies both the possibility and the opportunity to engage with and criticize the status quo-literally, to "speak truth to power." Recognition of and knowledge about dissent is essential to effective social influence, but recognition can be granted to a pseudonym or an organization whose membership is not public_one might make this case about the "Anonymous" digital collective. The possibility of persecution, as Leo Strauss (1952) observed, has required many a great thinker to seek to avoid censorship and write between the lines to avoid incurring danger. Dissent usually implies externality-action apart from the centers of power; although one great form of institutionalized dissent is the judicial dissent in the Anglo-American tradition. Dissent should be intentional, not accidental; critical rather than laudatory; public rather than private (Collins and Skover 2013). ${ }^{2}$ Dissent is disruptive to be sure: not without

2 Ronald K.L. Collins and David M. Skover recently challenged twenty-two academics and public intellectuals-whom they call Informationis Personae-in the United States to answer a series of questions on judicial dissent, peaceful protest, civil and uncivil disobedience and political violence, particularly with reference to American examples. Interviews were conducted from 2004-2012 with the following individuals: Randy E. Barnett, Todd Gitlin, Sue Curry Jansen, Hans A. Linde, Jon O. Newman, 
reason do authoritarian regimes constrain or prohibit dissent. At the same time, however, dissent contributes to the texture of democracy: dissent enables selfgovernance, civic participation, and promotes diversity and tolerance. Finally, dissent is normatively positive-branding something as "dissent" is at least partly an exercise in legitimation (Collins and Skover 2013).

Dissent is also a category narrower than resistance. Resistance includes everyday activities, such as absenteeism from work, deliberately low productivity, or simply deliberate retreat into the private sphere. What makes resistance political, however, and perhaps transforms it into dissent, is its purposeful and public nature. Dissent requires entering public space and living "as if," in Václav Havel's (1991) famous formulation. Still, there is no clear-cut line between resistance and dissent. They are poles on a continuum.

Dissent is inherent in the canon of political thought. Dissent in its public and political form is part of what separates philosophy from political philosophy. The earliest protagonists and interlocutors of political philosophy were themselves dissidents. During his trial, Socrates' famous refusal to renounce his pursuit of the truth via his dialogical investigations initiated the canonic narrative of speaking truth to power. Indeed, even conservative Straussian methodology makes it clear that persecution was inherent in the art of writing and philosophizing - the pen was considered as dangerous to ancient and medieval authorities as the sword (Strauss 1952). To dissent was not simply to advance alternative ideas. It was also to challenge existing political structures. Put in twentieth century language, antipolitics inevitably becomes political (Konrad 1987; Falk 2003a).

Modern dissent, however, has at least three overlapping origin stories: first, with the rise and consolidation of the post-Westphalian state; second, with the emergence of religious dissent and the ensuing debate on toleration; and third, with a one-step forward, two-steps back (and violent) emergence of liberalism. ${ }^{3}$

Steven H. Shiffrin, Nadine Stroessen, Noam Chomsky, Steven K. Green, Sut Jhally, Catherine A. MacKinnon, Martha C. Nussbaum, Faith Stevelman, Michael Walzer, Howard Zinn, Phil Donahue, Kent Greenawalt, Anita K. Krug, Ralph Nader, Frederick Schauer, Geoffrey R. Stone and Cornel West (Collins and Skover, 2013).

3 As a competing origin story, I would suggest that Marxism, as both an alternative explanation of history and praxis, "distorted" these intertwining trajectories of dissent because conflict was reduced to class conflict as a) materialist in basis and structural in origin; b) historically inevitable, and thus leading to revolutionary violence; c) resulting in a utopian future with a teleological drive to better humanity. In the process, liberal "rights" such as freedom of expression and conscience/belief were sidelined as both epiphenomenal and inconsequential. At the same time, the path to liberalism as 
However, we cannot speak of dissent in terms of organized communities or subcultures acting in concert against monarchical or nascent state authority before the English Civil War and, on the continent, before the conclusion of the Thirty Years War with the Peace of Westphalia (Hill 1980). Early views on toleration, beginning with Locke's Letter on Toleration (Epistola de Tolerantia), primarily concerned religious dissent. After all, prior to the Reformation and subsequent wars of religion that raged across the continent, diversity in belief was considered apostasy to be eliminated. Over time, the idea of protecting difference of opinion and enshrining that protection legally was intimately intertwined and logically connected to liberalism and republicanism. State sovereignty, originally a political answer to religious discord and a means of guaranteeing continuity from one monarch to another (Bodin), was later re-fashioned to ensure obedience to authority in exchange for protection (Hobbes), and finally became the mechanism that enabled legal relationships between and among states (Grotius). By the nineteenth century states would become both the targets and agents of reform, and sovereignty would be seen as vested with citizens, rights-bearing individuals who in France and America had already demonstrated their propensity to resist tyranny and foment revolution. At its core, dissent fundamentally depended upon the existence of minority communities who were willing to challenge sovereign authority over them.

Historically, I suggest that dissent in its distinctively modern character begins with toleration. This was not really an auspicious beginning, because, as thinkers as diverse as Wendy Brown (2006) and John Gray (1995) have argued, toleration does not connote a pre- or proto-liberal multicultural acceptance of the Other. Rather, the object of what was to be tolerated was considered a priori to be inferior. Still, in toleration there is a line of reasoning that wends from John Milton and John Locke through to Oliver Wendell Holmes, especially regarding the necessary relationship between toleration and freedom of expression. We believe in a Holmesian "marketplace of ideas" not because we relativistically think all ideas have some value (after all, does European fascism have some sort of positive provenance?) or because we skeptically cannot discern the good from the bad, but because acceptance of odious ideas or the individuals or groups that espouse them confirms that we have the ability to reason and to debate in the public sphere. We

a defining feature of political culture has hardly been peaceful: each previously unrepresented (or worse, unconsidered) group demanding enfranchisement or rights in the public sphere was met with violent and ideological backlash prior to and continuing even after political recognition-women and visible minorities are a case in point, and the same processes continue today with LGBTQ communities. 
know historically and currently that freedom of expression is absolutely critical to dissent. If not allowed, claiming such expression is the first and foremost activity of dissent. Dissent is as much about the process of free expression as it is about the actual content.

During and after the English Civil War, included among the belligerents and refugees of that conflict (using contemporary parlance) were the many marginal Protestant religious sects that left England and Scotland for the New World to establish, ironically, what turned out to be internally repressive communities in the name of religious freedom and tolerance. Not without good reasons were they called Puritans. As Albert Hirschman (1970, 106-10) suggests, they exited, taking both their voice and loyalty to America. ${ }^{4}$ Yet in their "Citty upon a Hill," to quote John Winthrop (1965), they intertwined utopian impulses toward God-given equality with a pragmatic commitment to a severe though effective ethic of hard work and individual responsibility-most particularly in one's lifelong accounting to the Almighty. These early dissenters were outsiders who sought religious autonomy and expression. Their questioning of religious belief nonetheless did not encompass a wider spirit of tolerance. American historiographical emphasis on the triumph of liberalism has tended to recast Puritanism as anticipatory liberalism (Rosano 2003, 33). Perhaps. Puritans dissented in the name of religious freedom. They were also, however, profoundly judgmental about each other and exclusionary towards others-think of the Salem witch trials as a means of dispensing justice, or attitudes of early settlers toward native communities, defined as savages occupying a terra nullius that could only belong to the banner-carriers of "civilization." Almost one hundred and fifty years elapsed between Winthrop penning his famous sermon, "Christian Charitie: A Modell Hereof," en route to the "New World" and the publication of Thomas Paine's 1776 pamphlet Common Sense. Winthrop excuses social and political inequality and hierarchy as evidence of divine providence. By the time Paine wrote, the public sphere was thick with discussion of man's inalienable rights-discourses that would underlie ideas of basic equality.

On the continent, meanwhile, a republic of letters formed a kind of virtual community of those privileged enough to be both literate and engaged. The free

4 Hirschman argues that American political culture has historically favored "exit" over "voice"-leaving behind the conflicts of the "old" world-and that this persisted through the idea of the frontier and the persistent widespread belief in upward mobility. In another sense, however, American dissenters exited the "old" world and then exercised "voice" through their utopian immigrant impulse, and "loyalty" to the new world they had created. 
circulation of ideas spread alongside social scandal and vituperative gossip in the salons of pre-revolutionary France, as well as among religious reformers who fled to Geneva, and in personal correspondence among a range of interlocutorsRousseau, Hume, and Voltaire, among others. Nascent capitalism played a role here. Jürgen Habermas (1994), for example, weaves together the many strands of the emerging public sphere: the explosion of literary and political broadsheets, reading societies, publishing companies, salons, as well as the cafés and coffee houses where the bourgeois could interact, argue, eat together, and imagine other possibilities of political and social organization. ${ }^{5}$ Perhaps ironically, it was the creative destruction wrought by capitalism which made this possible. It expanded the public body at the same time as it excluded and repressed others through the burdens of wage labor. Nonetheless, this central contradiction-between the liberal republican ideology of the modern state (best originally expressed in the American Constitution and Bill of Rights) and the economic exploitation and intensive/extensive growth that capitalism made possible-has provided fodder for the mill of dissent ever since. In the U.S. particularly, waves of dissentersfrom abolitionists to anarchists, from labor activists of the Communist Party of the United States of America (CPUSA) and the Civil Rights Movement to the Women's and Lesbian Gay Bisexual Transgender Queer Rights Movements-have sought the actual fulfillment of the promise of the American dream for everyone (as opposed to for elites privileged by economic and historical advantage [Kazin 2011; Kazin 2014]). Whether or not such dissenting movements either abhorred or advocated violence to achieve their results has long been a subject of debate and political prosecution in both Europe and the U.S.

\section{Violent and Non-Violent Dissent}

From its earliest origins, it was and still remains difficult to separate dissent from violence. Indeed, working at a military staff college for mid-career and senior officers, I jokingly tell students and colleagues that I research and write about "regime change from below;" that is, in order to distinguish my research from state-sponsored (and usually violent) regime change. In the public sphere, and particularly in the media, we often play fast and loose with the terminology of dissent, partially because we normatively choose to attach the label "dissent" and "dissident" to sub-state activism of which we approve. Indeed, we valorize dissent

5 Habermas' work, especially after its English translation, had a profound and continuing impact on the post-Cold War "turn" away from the state to civil society (Calhoun 1994; Cohen and Arato 1992; Seligman 1992; Keane 1998). 
and consider it worthy and deserving of the label when it is anti-authoritarian, inclusive, liberal in character. We also prefer it to be non-violent. Indeed, there is a burgeoning literature on not only the moral legitimacy of non-violence but on its superior efficacy as well, such as Jonathan Schell's The Unconquerable World: Why Peaceful Protest is Stronger than War and Erica J. Chenoweth and Maria J. Stephan's Why Civil Resistance Works: The Strategic Logic of Nonviolent Conflict (Schell 2005; Chenoweth and Stephan, 2013). There are moral, pragmatic, and compelling evidentiary arguments to endorse non-violent rather than violent dissent across differing geographic and historical contexts (Kurklansky 2006; Jahanbegloo 2014). Chenoweth and Stephan $(2013,10)$ argue that nonviolent campaigns offer a "participation advantage over violent insurgencies" because of lower "moral, physical, informational, and commitment barriers" to participation. Mobilization is easier; participation higher and more representative, disruption to the polity is greater while physical infrastructure is less harmed. The resulting transition is more durable with a lower probability of civil war.

Still, the full scope of dissent is much more problematic. Dissent, as suggested earlier, is part of a larger continuum that includes not only private rebellion, traditions of public passive resistance and civil disobedience (from Thoreau to Gandhi's satyagraha), but also violent sub-state activism as well. Concern for property, a counter-revolutionary zeal to protect privilege post-1789, and the emergence of laboring classes-urban, pauperized, and without voice-all resulted in an early equation of dissent with violence. ${ }^{6}$ Dissenters were called terrorists early and often. Not without reason did Marx see violence as a necessary accompaniment to every revolution -in the first volume of Das Kapital he memorably states, "...force is the midwife of every old society pregnant with a new one" (Marx in Tucker 1978, 436). Georges Sorel, in Réflexions sur la violence, theorized that violence was not only necessary to political will and direct action, but was also purifying (1910). John Keane (1996) reminds us that civil society contains uncivil society. In short, dissent and violence have, in the past and in the present, been regular bedfellows. One the one hand, violence can be seen as human failure: especially to the extent violence has accompanied revolutionary socio-political change-decolonization, superpower disputes, and insurgency and civil war-violence does often beget violence.

6 Arguably this equation reaches back much further, to the Luddites in England and even earlier medieval peasant rebellions across Europe. To equate dissent with violence was also to justify its oppression in the name of order, stability, and progress. See in particular Hobsbawm (1962) and Thompson (1980). 
Still, violence can yield results. Chenoweth and Stephan $(2013,11)$ note that while one in four nonviolent resistance campaigns since 1900 was a failure, more than one in four violent resistance campaigns have succeeded. What they call "violent insurgencies" are more likely to succeed when featuring widespread popular support and some form of external sponsorship (note how when the adjective "violent" is involved the predicate noun is often more pejorative.

The relationship of dissent to violence is a discomforting one. Collins and Skover $(2013,68-9)$ want to separate the two (specifically excluding violent behavior from dissent). They maintain that the rhetorical value of dissent is devalued by violence and that perpetrators of extreme violence may seek to overthrow rather than reform the systems they oppose. Still, they draw the same distinction as many of their interlocutors: that targeted harm to property is of a different scale and effect than harm to people, especially innocent people. The relative powerlessness of the person or group responsible for political violence, combined with an overall acknowledgement of the rule of law and acceptance of punishment are mitigating factors that also require careful consideration (Collins and Skover 2013, 70). One would be best advised to keep in mind Max Weber's $(1981,125-8)$ advice to those seeking politics as a vocation: to supplement an ethic of ultimate ends with an ethics of responsibility in order to temper possible illusions of ethical legitimation of violence for "higher" ends.

I would like to provide some context by looking at the example of Nelson Mandela and the African National Congress. In this case, the majority was powerless in favor of a minority, both of whom were racially defined. Mandela, it must be remembered, never gave up his commitment to violence while imprisoned. Following the Sharpeville massacre in 1960, the Apartheid government in South Africa declared a state of emergency. The African National Congress (ANC), then an illegal organization, moved from peaceful non-violent dissent to a strategy of targeted violence through the creation of Umkhonto we Sizwe (Spear of the Nation), the ANC's military wing. As undergraduates and anti-Apartheid activists in the early 1980s, fellow students and I used to debate the utility of force. It was difficult to square the impossible circle: we decried state-sponsored violence in Central America, opposed the madness of nuclear arms, yet still defended the ANC's tactics. This got to the point, though: the Apartheid regime tried to make the renunciation of violence a precondition of Mandela's release-a precondition to which he never assented (Meredith 2010; Sampson 2011). In the end, of course, Mandela's great achievement was the relatively peaceful end of Apartheid, the 1994 elections, his tenure as president, and the difficult process of reconciliation that followed (relatively peaceful events). As much of an emissary of peace as he 
became, however, perhaps the greatest illustration of Mandela's political genius was his understanding that by holding the violence card firm, the ANC could renounce violence on its own terms. ${ }^{7}$ That is, especially as the security and military apparatus of the Apartheid state always wielded the preponderance of power.

Many writers today-most notably Paul Collier-see civil wars and rebellions as effectively failed movements of dissent; movements ultimately driven more by greed than grievance (Collier and Hoeffler 2004; Collier 2007). To muddy the waters even further, some of the groups listed as "terrorists" by states and international organizations also provide health and social services-Hezbollah in Lebanon is a prime example. Moreover, organizations such as the Fuerzas Armadas Revolucionarias de Colombia (FARC) have degenerated from a rural protest movement based on Marxist premises to a large-scale drug export operation functioning on extortion rather than consent. Still, what if strategically targeted violence is as historically effective, at least at times, as peaceful dissent? What if avenues for peaceful dissent have led nowhere, leaving violence as one of the few options available aside from capitulation and acquiescence? Context, as the case of South Africa illustrates, matters. One might be tempted to suggest that revolutionaries and those whose intention is the wholesale replacement of a regime ought not be considered dissenters. This might make sense in democracies where the avenues for civil disobedience and dissent are plentiful. Much of global dissent occurs in undemocratic contexts, however, or where democracy is failing or tilting dangerously toward authoritarianism (for example, the Russian protest movement of 2012 and the 2014 Maidan protests in Ukraine). There, dissent only through word or peaceful demonstration might be too much to expect.

\section{Cold War as Dissent}

If one were to write a longue durée history of dissent, a special chapter in the volume would need to be devoted to the alternative civil societies, parallel polei, second or alternative cultures, and self-organized societies of Central and Eastern Europe during the Cold War (Konrád 1987; Benda 1988; Kuroń 1981; Skilling 1989; Skilling and Wilson 1991). In my opinion, authoritarian communist regimes were never as successfully totalitarian as Hannah Arendt (1976), or Carl Friedrich and Zbigniew Brzezinski (1965) suggested. Still, there was a fusion of party and state, combined with a command economy and rigid ideology that dictated a

7 Ultimately, this was achieved with what became known as the Pretoria Minute, after a meeting on August 6, 1990 the ANC signed an agreement suspending the armed struggle launched nearly thirty years previously (Meredith 2010, 413). 
narrow, controlled, and highly scripted form of mandatory political participation (one encapsulated by Václav Havel's [1991] greengrocer in his rote placement of the sign, "Workers of the World Unite," in the shop window). Homo Sovieticus lived in an ersatz public sphere, a world dictated by ideology, a world of appearances that, like living in Plato's cave, could be easily mistaken for reality. The greengrocer's action from Havel's prose, so minor and routine, signaled his base obedience, but also his complicity with the regime. When he removed the sign, he was not unlike the man in Plato's cave who steps out into the sunlight for the first time. Human virtues long suppressed-self-realization, freedom, authenticity, and an explosion of diversity in cultural, social, and political forms-were the necessary result.

The mechanics of text, the slow and artful nature of samizdat production and circulation was limited in one sense, but illustrated the unlimited potential and power of the written word (samizdat were hand-produced dissident pamphlets). Not unironically, samizdat privately disseminated through alternative networks provided a great illustration of Foucault's (1980) equation of power and knowledge, as well as Scott's (1990) more recent claim that forms of dissent are sometimes disguised or hidden. Before the Internet and the explosion of communications technologies, samizdat demonstrated that the circulation of ideas via the printed word was no mean feat. The circulation of text enabled many things at once, which at first seem very limited and local. As Jonathan Bolton (2012, 191) describes, samizdat helped birth the creation of a "circulatory system of a social grouping - a network of interlocking contacts, finite but unbounded... essential to a community's self-definition." The production of samizdat and the circulation of tamizdat, with concomitant debate and decision-making, eventually made possible the full articulation of an oppositional identity (Bolton 2012, 117; Kind-Kovács and Labov 2013).

Still, the normative labeling of dissidence, perhaps only possible through the lens of Cold War triumphalism, reflects the dominant liberal perspective of the victors rather than the vanquished. There is a heroic narrative-my own work is guilty of this as much as any other-of telling the tale of the dissidents of Solidarity and Charter 77 in a manner that privileges the anti-authoritarian, indeed liberal, character of alternative civil societies while assuming without question that the U.S. and its allies in Europe and elsewhere were on the side of the angels, even while they were engaging in a little regime change on the side or supporting dirty wars in the name of anti-communism (Falk 2003a). My current work, on the American communist party, is a personal and longer-term effort to peel back another layer of the onion. To understand how the construction of friends and 
enemies, both domestic and international, was part and parcel of the Cold War. Both East and West engaged in the demonization of internal enemies as dangerous Fifth Columns operating covertly on behalf of the external foe, and persecuted and prosecuted those rightly or wrongly associated with the other side to the point of occupational harassment, continual surveillance, imprisonment, deportation, and even death. Indeed, my current project looks at the many "true believers"the leaders of the CPUSA in the late 1940s and early 1950s that were put on trial for allegedly conspiring to teach and advocate the violent overthrow of the US government-as "dissidents" in their own right. Many American communists, at considerable personal risk, challenged the American state to end racial segregation, establish women's and tenants' rights, as well as advocating free medical care, progressive labor legislation, and fair employment practices decades before such policies were supported by mainstream groups or eventually implemented. Interestingly, it was not the CPUSA that advocated or implemented tactics of violence in twentieth-century America. Rather, political violence was the hallmark of anarchist assassins and bomb-makers much earlier in the century, or groups like the radical Weather Underground in the early 1970s. Not all CPUSA leaders were "clean"-we now know, thanks to declassified evidence and a range of scholars that many of the true believers who saw the USSR through rose-colored glasses did engage in espionage or act as willing accomplices or agents of influence in one manner or another (Klehr, Haynes, and Vassiliev 2009). We also know, however, by peeling back the layers of the onion of dissent in Central and Eastern Europe, that organizations such as Solidarity were funded covertly by the CIA (Fischer 2012). Movements were penetrated by those who willingly, or more often under some threat of reprisal, informed or, in the American parlance, "named names" to state security agencies (Stan 2009; Bruce 2010). In the former East Germany, the level of societal surveillance reached such heights and was of such variegated quality and utility, even by the Stasi's own standards, that it is impossible to be a purist and exclude those who informed from the category of dissent. Many cooperated not out of enthusiasm but for fear of the consequences if they did not (Bruce 2010, 148).

In the post-Cold War debate about whether what happened in Eastern Europe was a revolution or restoration, it seems now we can say the answer is both/and. In one sense, as many analysts of the region have pointed out, it was a revolution in the idea of revolution, divorcing all-encompassing social and political change from violence (Roberts and Garton Ash 2009; Falk 2013; Falk 2003a; Falk 2003b; Nepstad 2011). The relatively peaceful end of the Cold War and the dismantling of Apartheid in South Africa were true high points in a largely violent century. What 
happened in the East-Central Europe with the emphasis on local and independent decision-making and practices outside the long arm of the party-state, reaffirmed the transformative ideas of liberty, equality, and solidarity of the French Revolution and the later binding of freedom with democracy. Ironically, before 1989 the dissidents had no intention to overthrow the entire edifice of communism. Their goals were more modest-allowing for independent self-governing trade unions, or holding their governments to account for the human rights protections they had guaranteed would be respected in the Helsinki Accords. Nevertheless, the mere fact of systemic collapse does not erase or taint the legitimacy of their dissent.

In another respect, the fall of communism was the conclusion of a worldhistorical project, another heir to the Enlightenment. Dissidents and their movements in Central and Eastern Europe were also part of a longer continuum of what Adam Roberts and Timothy Garton Ash (2009) call "civil resistance" and Peter Ackerman and Christopher Kruegler (1994), along with practitioner Gene Sharp (1973; 2003; 2010), have called "strategic nonviolent conflict"- the use of "people power" to bring down imperial projects, authoritarian governments, and exclusionary policies, which includes the non-violent elements in Russias "First" revolution in 1905-1906, the Indian independence movement, the American Civil Rights Movement, mass public mobilization against the rule of Ferdinand Marcos in the Philippines and against General Augusto Pinochet in Chile in the 1980s, and the more recent "colored" revolutions in Serbia, Georgia, Ukraine and Burma (Nepstad 2011).

The regime-change of 1989-1991, however, also contained another powerful current of restoration and rehabilitation-Tsarist-style authoritarianism in Russia, or what Vladimir Putin euphemistically calls "managed democracy" (a rampant form of crony capitalism effecting the privatization of the wealth of nations into the hands of a few and enough state-directed persecution and violence to promote societal quiescence). Here, energy revenues reinvented a social contract and survivalist impulse: a decent life is possible if you keep your head below the parapet. Even as liberal urbanites who benefited from Russia's energy-fueled economic resurgence have increasingly disengaged their support for the regime-for a number of months in 2012 taking to the streets in protest-there remains a silent Russian majority, somewhat poorer and disconnected from Moscow, that sees in recent expansionist Russian foreign policy and nationalist and exclusionary domestic policy the resuscitation of great power and pride after two decades of post-Soviet shame. Sadly, the reality remains that the dissident experience of mid-to-late twentieth century Mitteleuropa is set comfortably in the past, whereas ongoing efforts to oppose authoritarianism in Ukraine, Belarus, Russia and Central Asia rest uneasily in the present. 


\section{Contemporary Dissent: Transnationality, Historicity, and Speed}

This continual experience of temporal and liminal dislocation brought by the end of the Cold War, combined with the tempo of social, economic, and cultural globalization and the explosion of late twentieth-century communications technologies, forces a further probing of the intersections of geography and culturebeyond the specific histories of dissent and dissidence in Europe and America. To what extent can we speak today of the transnational meaning and trans-historical relevance of these experiences of dissent to past and current movements outside the European, white-settler universe? What about the almost simultaneous emergence of multiple movements and sites of protest, and indeed the contemporary emergence of transnational movements of dissent, as witnessed in the anti-globalization movements of the late 1990s - the global environmental movement or the Occupy Movement, for instance? We used to speak of alternative civil societies bounded by state and regime borders. Now we speak of "transnational" or "global" civil society.

How well do concepts such as civil disobedience, the self-constitution of civil societies separate and apart from the state, Adam Michnik's idea of "new evolutionism," or Havel's suggestion of the "power of the powerless" conceptually stretch and meaningfully "travel" elsewhere (Havel 1991; Michnik 1985)? Why delete the question mark, when this is a question? Are we engaged in a form of Orientalist magical thinking when we interpret what is happening in the Arab Spring through the lens of prior European and American experience? Effectively, due to imperialism, the transformative reach of industrial and post-industrial capitalism, and post-Cold War globalization, the entire world has been conquered by the weight of European structures of domination, culture, and the Enlightenment. At the same time, groups such as Amnesty International and Human Rights Watch are not simply the handmaidens of "Western" conceptions of rights. After all, there are strong universalist arguments to be made about at least a de minimus list of rights immune from charges of cultural relativism, and the absolute "right to life, liberty and security of the person", to quote from the Canadian constitution, ought to be at the top of the list. ${ }^{8}$

8 Section 7 of the Canadian Charter of Rights and Freedoms, effective since 1982 as part of Constitution Acts 1867-1982 and the repatriation of the Canadian constitution from the United Kingdom, states "everyone has the right to life, liberty and security of the person and the right not to be deprived thereof except in accordance with the principles of fundamental justice." Supreme Court of Canada jurisprudence has put great emphasis on this section, and has interpreted in broadly and substantively. 
Regardless of my own specific, historically and geographically limited research, dissent, in the contemporary sense, is an unmistakably universal phenomenon. This is particularly true in view of the geography of dissent and significant levels of political protest over the last decade: Bahrain, Bulgaria, Burma, China, India, Iran, Israel, Greece, Hong Kong, Thailand, Russia, Spain, Syria, Tunisia, Ukraine, and the United States. Democratization and civil society recipes, as cooked up by aid agencies and NGOs, do not succeed when historically decontextualized, to be sure. Past experiences, under spatially and temporally different circumstances, with a working vocabulary of concepts and organizational tactics, require sensitive, constant, and specifically contextual cultural translation. Ideas about civil society organization, social mobilization, civic activism in the public sphere, non-violent resistance to authoritarianism in its many guises and historical cloaks, democracy, and human rights are not, in the twenty-first century, confined to Europe or its dominions overseas. Yes, a maddening level of conceptual stretching has and will continue to occur. Looking specifically at how the theoretical and practical innovation of the Central/ East European dissidents "traveled" in the post-communist world, I spent some time looking at the Middle East both just before and just at the beginning of the Arab Spring. I concluded, that to suggest democracy or human rights is incompatible with Islam or Arab cultures is a breathtakingly narrow_indeed an Orientalist—view (Falk 2013). Ideas about human rights, non-violent change through civic participation and resistance, and democracy are today the collective property of humanity. To assert otherwise is not cultural relativism. It is to excuse criminal behavior, to paraphrase Canadian women's rights journalist Sally Armstrong (2013).

Looking beyond the Middle East and North Africa, we see the further globalization of contemporary tactics and strategies of dissent, in places as far apart and diverse as Burma and Brazil, China and Cuba, India and Iran, Kenya and Kyrgyzstan. Contemporary communications technologies and social media have made possibilities for dissent much more rapid and globally networked. Much was made in the mainstream media about the role of social media in Iran's Green Movement and during the Arab Spring, Occupy Movement, and the recent waves of protest in Europe and Israel. Coordination was made possible with Twitter and Facebook; tactical creativity was shared through text messages; imagery was uploaded directly onto YouTube for global consumption. Yet social media, according to Krastev, has also contributed to "protest frustration." Here, social networks engage in a downward spiral of mutual incrimination and conspiracy theory-as occurred in Russia following the 2012 protests (Krastev 2014).

Moreover, those same technologies provide state institutions and apparatuses new platforms for control and repression, intersecting the knowledge potential of 
"big data" with levels of surveillance and resulting power that would make Orwell or Foucault shudder (Morozov 2011). Bentham's Panopticon is a global reality, and we are all captured in a diffuse web of power exercised in a regulatory and administrative manner. That provides all the more reason for the need to update and safeguard law and policy—nationally and transnationally-regarding freedom of expression. There are intrusions on our liberty today that John Stuart Mill could never possibly imagine in his construction of the harm principle-insidious invasions of privacy and tentacles of security governance that seem more at home in the realm of Aldous Huxley (Mill 1979). Where we situate ourselves with respect to this brave new world can be arrived at by our own mental shorthand answers to what we think about the revelations of Wikileaks or whether Edward Snowdon is to be decried as a traitor or celebrated as a whistle blower (Cole 2014).

As much as things change, it is nonetheless important not to think of the past as overly culturally and nationally bounded, trapped in technologies that were not far past Gutenberg when it came to the publishing and circulation of texts and ideas. When interviewing former dissidents in Czechoslovakia, Hungary, and Poland after the fall of the Berlin Wall and the collapse of communism, one of my questions focused on who or what influenced their views. Who and what did they read? Their answers were complex: they cited Thoreau, King, and Gandhi, as well as Arendt and Orwell. They were globally aware and well read. The lack of a consumer-oriented culture meant they devoted considerable time to reading. Yes, they were steeped in Marx and Lenin - more than a few began as revisionist, humanist Marxists—but in Locke and Hegel as well. Tellingly, and importantly, they read each other: despite the authoritarian, ideologically rigid, and constraining nature of the regime, via samizdat, tamizdat, smuggling (often with the able assistance of Western embassies and agencies) and personal travel, and with some determination and no small amount of personal risk, they had access to a lot of material. They established flying seminars and universities. Because of the actions of the Jan Hus Foundation in Czechoslovakia, you could earn credits toward an Oxford degree under the very noses of the authorities (Day 1999). Reflection and discussion were inseparable from action.

Indeed, historicity and historical awareness is absolutely essential for effective dissent in the twenty-first century. Much can be accessed via the Internet, but not in all states, given national firewalls such as those erected in China, Saudi Arabia, and Iran. Moreover, the presence of information does not equal accuracy or access; description does not equal analysis (measuring the effectiveness of dissent is a difficult proposition in any event). An accessible and usable past means knowing when innovation is urgently required, and when re-inventing the wheel is a waste of time. In the fall of 2011, I was fortunate enough to be in New York 
just as protestors began occupying Zucotti Park in lower Manhattan, giving both name and voice to the "99\%." After wading through the tented settlements, reading signs, talking to the earnest Occupiers while literally tripping over computer cords, wires, and journalists (by mid-October, there were as many journalists as occupiers), I found the "library" - a bunch of plastic bins in a corner of the park. In one of the bins was a copy of David Caute's (1979) magisterial analysis of McCarthyism, The Great Fear, alongside a "do it yourself" guide to commodity futures trading. Both were perhaps essential reading for understanding America's past episodes of repression as well as the greed and irrational exuberance that led to the global financial meltdown of 2008-9. Nobody was reading, though; they were busy doing. It bears remembering that Wall Street has a rich background as prime real estate for dissent, and that movements stressing participatory democracy, civil disobedience, non-violence, and social justice have been around for centuries in America. Many of the Occupiers, in the more than two hundred years' worth of old media content they generated, spoke of popular disenfranchisement and the over-privileging of elites (in these two respects, not unlike the Tea Partiers), as well as social justice, participatory democracy, and civic engagement. Based on my observation, they seemed determined to reinvent the wheel of dissent, something that has been rolling along nicely for centuries. Indeed, a book published at the same time, Michael Kazin's (2011) American Dreamers, advanced the thesis that the indigenous, Made-in-America Left-abolitionists, feminists, socialists, anarchists, and even communists - had changed the face of the country forever and made a lasting impact on American society and its values.

Learning from the past has never been more urgent. After Iran's "stolen elections" in 2009, I had the opportunity to learn from and meet with a group of Iranian student activists at the University of Toronto. They wanted to know more about Solidarity in Poland. Long before the Iranian blogosphere, Polish activists in Solidarność were communicating via a panoply of self-created free and independent media: newspapers, bulletins, magazines, posters, and political cartoons. What could these students learn from creating an independent civil society in the face of regime crackdown? In one sense the task of the Iranians in terms of communication was easier. The stakes were nonetheless much higher-imprisonment in Teheran's notorious Evin Prison and a potential death sentence are definitely harsher outcomes than those faced by any dissidents in the post-Stalinist era.

Because of the emphasis on speed in our current context-instant communication by smart phone, the myopic amnesia characteristic of the twenty-four hour cable news cycle, the short-term thinking of politicians, and the immediate gratification promised by easy credit and consumer capitalism - there is a bizarre 
expectation that dissent will somehow produce immediate results. Historically revisionist and mistaken readings of past episodes of dissent have informed policy makers and pundits alike in believing that a crowd toppling a few statues and/or forcing an ailing dictator to retire early might generate successful regime change or democratization on the quick and cheap. Perhaps this is why dissent increasingly takes the form of global street protest. Ivan Krastev (2014) has examined protests from 2011-2104, from "Occupy Wall Street" to Vladimir Putin's "Occupy Crimea," and suggests some disturbing trends for both the future of dissent and democracy. This new wave of politics-amplified through social media and global interconnectedness-offers more in terms of moral indignation than actual ideology or programmatic alternatives. In Canada, dissent has generated some corporate and political responsiveness: executives and think tanks suggest that "social license" is needed to generate community support for development, independent of regulatory processes. Dissent for the sake of dissent risks reducing the whole enterprise to a large-scale NIMBY-ism ("not in my back yard") that can undermine longstanding structures of political representation necessary for democratic functioning (Gerson 2014). ${ }^{9}$

The protests have generated the shared experience of revolt. They have created senses of resistance, and their experience has certainly been recorded and shared in public space, both real and virtual. However, the jury is out as to whether their protagonists will define demands consonant with political inclusion, transparency, and accountability or only in terms of lifestyle improvement. Krastev's concern is that the current wave of global protest, unhinged from the state yet devoted to the extravagances that define capitalist success, has a decidedly consumerist and libertarian flavor. On the other side of the coin, Naomi Klein $(2014 ; 2008$; 2000 ) has passionately and repeatedly argued that contemporary protest politics, emerging with the alter-globalization protests of the late 1990s and early 2000s, signal the rejection of market-based capitalism and its many failures-from the hollowing out of the middle class to the exploitation of developing world workers and global environmental destruction.

As I see it, history ultimately reminds us that while it is exhilarating to focus on the peaks of dissent-the euphoric moments of mass social mobilization when civil engagement is highest and anything seems possible-the reality is that such

9 In the Canadian context, the term "social license" was coined in 1997 by British Columbia mining executive Jim Cooney: at the time extractive industries in the province were subject to considerable social protest and environmental criticism over practices which were significantly damaging to the province's wilderness, particularly the clearcutting of old-growth forest (Gerson 2014). 
moments are often preceded by many failed efforts, violent repression or various turns to and/or against violent tactics, ideological confusion, social apathy, fear, and disillusion. The story of Solidarity might begin in the Gdańsk shipyards of August, 1980; it has concrete origins. But the organization is nonetheless the successor of so many previous efforts that if you wanted to be fully accurate, you could trace its origins back to the dismemberment of Poland in the late eighteenth century, the failed insurrections of the nineteenth century, the intellectual ferment of the Polish intelligentsia between the wars, the Polish October of 1956, the student protests of 1968, the workers' protests in 1970-71, the formation of KOR following the Radom-Ursus riots of 1976, or the Pope's visit in 1979. All these previous "moments" of social mobilization, peaceful or violent, political or decidedly not, played bit parts in the Polish dress rehearsal to Solidarity. This diversity of origins is instructive.

\section{Dissent and Leadership}

The issue of dissent and leadership is controversial, especially in the aftermath of the global Occupy movement and the more recent protest movements. Krastev's diagnosis is bleak: they are leaderless and ideologically rudderless, embodying a kind of "participation without representation" wherein the protestor wants community and democracy but trusts neither politicians nor elections (Krastev 2014). Back in 2011, the protest narrative suggested they were not as leaderless as the media contended-they were, in fact, leaderful, and all empowered via social media to communicate. Consensus and voice were highly valued, while charismatic leadership was eschewed. The "general assemblies" in Zucotti Park relied on local participation and debate. Still, one of the criticisms levied at Occupy was that its ineffectiveness was linked to its real and perceived lack of leadership. The underlying approach was to not sacrifice the range of issues or lose the radicalizing participatory ethos: fair enough. Nevertheless, my own research tilts towards the importance of leadership in movements with the long-term goal of building sustainable change, especially at critical junctures of mass mobilization and global media attention. Although the debates about leadership with respect to Occupy continue, and are linked with critiques that the movement(s) failed to concretize their grievances with policy-prescriptive demands, Occupy did have lasting results. The catchy sloganeering of the " $99 \%$ " versus the " $1 \%$ " has dramatically changed public discourse. It has put income inequality and tax reform on the agenda for the first time in decades. It has made protest catchy. In any event, Occupy's lingering effects are still not known. The transformation of language has altered the parameters of the discussion in the short run; in the longer run, a genre 
of scholarship is emerging to answer Occupy's critics' claims that the movement required substance or that concrete economic analysis and new policy agendas are needed (Malleson 2014, Piketty 2014).

However, the extent to which protest movements distrust elites to the point of eschewing the necessary social trust for effective representation and leadership, it would seem difficult to navigate a path to lasting results. There is a spirit of anarchistic and libertarian revolt against the very notion of being governed-here is where the Tea Party in the United States meets the disillusioned and cynical anarchist. Krastev decries the comparison of today's wave of protest to 1848 , even suggesting that they are the negation of noble nineteenth century demands for universal suffrage and political representation, because angry crowds are not about the hard work of obtaining a voice and working in or even developing new political institutions, but about regime downfall and defeat as an end in itself.

What is extraordinary about contemporary waves of protest is the scale of participation. Over two million Spaniards took to the streets in 2011, over one million in Brazil in 2013 (Krastev 2014). Over a million Egyptians marched in 2011 to force Hosni Mubarek from power; two years later an equally large number protested against the government of Mohammad Morsi and the Muslim Brotherhood. Global protestors are also globally aware and respond to one another. Yet for all the speed, connectedness, and high numbers, there have been many disappointments. Syria is a disaster; Putin is still in the Kremlin; in Egypt the military is back in power. Still, though Ukraine may be subject to an increasingly troubling civil conflict and Russian-sponsored destabilization, the Euro-Maidan protests effectively toppled a corrupt government, and Tunisia is an impressive success that merits more attention. In Ukraine, there were clear demands, most particularly the signing of a free trade deal and association agreement with the EU. Tunisia, structurally better off than many of its neighbors, with a relatively prosperous and educated middle class, has fared better, including the rise of more competent and creative leaders. Interim president Moncef Marzouki and his advisors are currently championing the creation of an International Constitutional Court, which would be responsible for monitoring and adjudicating access to power, especially during difficult political transitions. Both examples illustrate the importance of ideas, and leaders to carry ideas forward.

One can absolutely sometimes mobilize a population without leaders. No particular individual may be necessary. History has involved many instances of spontaneous popular action (ask the women who marched on Versailles in the October Days of 1789). Inspiration may nonetheless be needed. There needs to be a method to articulate objectives and goals. Leadership concentrates 
that articulation, personalizes inspiration, and allows for interlocutors-the "power" that "truth" is speaking to-and regularized means of establishing trust or recognizing the potential of an adversary. To paraphrase Pierre Bourdieu $(1980,59)$, when you enter a field of action, you have to accept the habitus that comes with the game. As Bourdieu states, "[...] undertakings of collective action cannot succeed without a minimum of concordance between the habitus of the mobilizing agents (prophet, leader, etc.) and the dispositions of all those who recognize themselves in their practices or words..." Moreover, you need to convince others, the "free riders"-those on the edges of burgeoning social movements who see no need to act-because the costs must be willingly borne by others. Leadership helps solve the collective action problem. Leaderless, you can change the conversation (as the various Occupy movements clearly did), but not legislative or institutional structures, as these structures function with elites and leaders at the helm. You need someone to be representative, to in fact represent rather than summarize or paraphrase the whole. Representation can be likened to mutual translation of a mass or movement to an elite and vice versa, an organization of interests so that bargaining and mutual gains are possible, demands can be concretized, and progress, however mundane and protracted, can occur. The battle for meaningful change becomes otherwise too utopian, too Sisyphean, and less likely to succeed.

One example is sadly illustrative: in a country of only 9 million, 450,000 Israelis took to the streets in 2011 demanding social justice and won the support of $80 \%$ of Israelis; but just as quickly as the carnival began, it ended (Shavit 2013, 358-359). Without effective leadership that could translate into political representation, and absent anything except amorphous demands, dissent quickly dissipated. That Israeli moment of hope has now been eclipsed by renewed conflict and retrenchment.

Like it or not, collective memory gravitates toward the hagiography of great leaders. It is often the case that someone is at least inspiring a movement, even if there is not an emerging leader, be she an historical figure or a contemporary actor. Leaders particularly skilled in the art of negotiation, i.e. compromise and mutual recognition, with an ethical and principled sensitivity toward justice in all forms-procedural, substantive, distributive, retributive, reparatory, transitional, and historical-have had the most impact and remain the subject of public adulation and serious scholarship. The examples are legion, and quite often come from the world of resistance and dissent: Mahatma Gandhi, Martin Luther King Jr., and Nelson Mandela, for example. However, there are also lessons from movement and leadership failures. These need to be equally studied and absorbed. Moreover, leadership and movement failure cannot be solely understood with reference to 
the tactical, operational, or strategic decisions or interplay of leaders and movements. Regime commitment to violence, the penetrability of international condemnation or even awareness, the enduring importance of historical legacies, and cultural variation all play a role that cannot be underestimated.

Arguing for the presence of leadership is not the same as suggesting that the current conventions about leadership or the literature on the topic-dominated as it is by sociology and by researchers in business programs-is up to the task. Historically, literature has focused on nebulous immeasurables such as traits, skill, and style as well as modalities that suggest approaches be situation-based, goal, path, achievement or participation-driven, collaborative, or results-oriented with lofty goals such as organizational excellence or transformation (Northouse 2004). Now-popular paradigms focusing on transformational leadership focus precious little on political or social transformation, as case studies are again dominated by the fields of study where leaders are considered to determine urgent material consequences-such as profit or shareholder value in market capitalism, or life-and-death, victory-or-defeat decisions in militaries. It goes without saying that such organizations are not structurally set up to value dissent in any variety. One of the approach's progenitors, James McGregor Burns (1978), does refer to Gandhi as a classic example of transformation leadership, whereby the hopes and dreams of the Indian independence movement were vested in one highly symbolic individual who in turn transformed both himself and the movement he led. One research prescription would be to plumb this literature for relevance to the social movement literature and vice versa. Archie Brown $(2014,148)$ has recently authored a significant tome on political leadership with chapters on transformational leadership, which he defines as playing "a decisive role in introducing systemic change," as well as revolutionary leadership. However, his analysis is one that might be characterized as "thick description" by historical case and example. He does not engage with the larger leadership sociological literature, but does mention that within the disciplines of politics and history, the topic is far too myopically dominated by studies of presidential leadership in the United States, hardly a genre conducive to examining dissent.

A final example of the importance of leadership, which also nicely contrasts regime change from below with state-sponsored regime change from above (military or international intervention), is to examine the effectiveness of singular actors in extraordinary circumstances and how they can touch a global public nerve. Actual armies, or their equivalents in humanitarian and development aid, turned out to be effectively powerful in implementing lasting changes necessary for the actual improvement of the lives of girls and women in states such as Iraq, 
Afghanistan, and Pakistan. But none of those armies have been as effective, I contend, advocating the importance of girls' education and women's rights as the efforts of a single young woman, Malala Yousafzai (Yousafzai 2013; Armstrong 2013). This is a young woman who has been violently attacked, but who has also, with grace, voice, and maturity, accepted the mantle of leadership, one that has now been recognized with a Nobel Peace Prize. Her enduring popularity is not simply a reflection of the symbolic nature of the violence she suffered, but rather about her principled response and stubborn refusal to allow her enemies any level of enduring success in stifling her message.

\section{Conclusion}

Dissent can be thought of as the highest form of political participation. This is a counter-intuitive conclusion, given that we think of dissidents as external to the established structures of power. Dissidents and dissenters are usually political part-timers. However, dissidents and dissenters are the concerned amateurs that take risks beyond the daily ebb and flow of life, regardless of the type of government they support, oppose, or wish to change. Democracies rest upon the consent of the governed, as Locke (1965) reminded us long ago, or even the dissent of the governed, as suggested by Collins and Skover (2013). The rancorous many that can withdraw their consent to the powerful few, or larger constellations of dissent, can eventually impact the many. That is, either inside or external to the institutions and practices of power. Indeed, this is exactly what Havel (1991) had in mind when he spoke of the power of the powerless. That this is the case even in the most authoritarian-indeed totalitarian-regimes is an extraordinary testament to both the importance of dissent, and its lasting impact. Often it is the dissidents and dissenters that are accused of sedition and even terrorism, even when they argue for loyalty to the patria if not the regime.

Regardless of regime type, American legal scholar Cass Sunstein (2003) suggests dissent as an antidote to three contemporary social phenomena: conformity, social cascades, and group polarization. Pressures to conform are amplified by the influence of those who confidently display authority as well as the seemingly unanimous views of others: in such circumstances, dissent can play an outsized role and temper or even change majoritarian views (Sunstein 2003, 14). Cascade effects occur over time when at first a few and then many people engage in similar behavior or action-from consumer purchases to religious conversions-on the basis of the perceived rightness of the action or expected social approval. Deliberative groups-from juries to political parties-often end up taking more extreme positions as a result of deliberation based on ingroup thinking or other partial 
or incorrect modes of information (Sunstein 2003, 10-11). Effectively, Sunstein extends Mill's argument regarding the tyranny of the majority from the context of law and politics into the broader public sphere. In so doing, he demonstrates that promoting and protecting rather than persecuting dissent not only serves public and political interests, but private interests as well.

The above meditations on the purposes, theoretical origins, and past episodes of dissent are but a sketch of dissent's enduring internal and existential contradictions. These include the delicate balance between the social tension dissent necessarily introduces and potentially amplifies and the well-functioning of society that dissent promotes, the effectiveness or anathema of violence, and the necessity of individual leadership for lasting collective action. Thinking of what Timothy Garton Ash (1999) has called the "history of the present" and into the future, we can see, given the impact of the speed and immediacy of social media, the transnationality of action, and the emergence of a truly global civil society, the current and future challenges of dissent. Freedom of association-and in that context, dissent-remains an essential litmus test of health in mature democracies, and a fundamental demand at critical moments of transition to democracy. Lockean consent of the governed is only meaningful if the governed can dissent and the polity still survives. Even when it does not-as dissent can give way to revolution, and has done so in the past-this is no reason to disallow the full range of free expression from discord to rebellion. Dissent will continue to allow us to test the validity of our political and social foundations; it will confront us with new and heretical ideas, challenging us to assume Weber's ethic of responsibility. As Hannah Arendt $(1974,247)$ suggested in her discussion of the vita activa, political action is ontologically rooted in the full range of human existence from natality until death. Only with the possibility for and of dissent can the full experience of our capacity for political action be realized.

\section{References}

Ackerman, Peter A. and Kruegler, Christopher. 1994. Strategic Nonviolent Conflict: The Dynamics of People Power in the Twentieth Century. Westport and London: Praeger.

Arendt Hannah. 1976. The Origins of Totalitarianism. San Diego, New York, and London: Harcourt.

Arendt, Hannah. 1974. The Human Condition. Chicago and London: University of Chicago Press.

Armstrong, Sally. 2013. Ascent of Women. Toronto: Random House. 
Benda, Václav. 1988. "Parallel Polis or An Independent Society in Central and Eastern Europe: An Inquiry.” Social Research 55 (1-2): 214-222.

Bolton, Jonathan. 2012. Worlds of Dissent: The Plastic People of the Universe and Czech Culture under Communism. Cambridge, MA: Harvard University Press.

Bourdieu, Pierre. 1980. The Logic of Practice. Trans. Richard Nice. Stanford: Stanford University Press.

Brown, Archie. 2014. The Myth of the Strong Leader: Political Leadership in Modern Politics. New York: Basic Books.

Brown, Wendy. 2006. Regulating Aversion: Tolerance in the Age of Identity and Empire. Princeton and Oxford: Princeton University Press.

Bruce, Gary. 2010. The Firm: The Inside Story of the Stasi. Oxford and New York: Oxford University Press.

Burns, James MacGregor. 1978. Leadership. New York: Harper \& Row.

Calhoun, Craig, ed. 1994. Habermas and the Public Sphere. Cambridge, MA: M.I.T. Press.

Caute, David. 1979. The Great Fear: The Anti-Communist Purge under Truman and Eisenhower. New York: Touchstone.

Chenoweth, Erica and Stephan, Mara J. 2013. Why Civil Resistance Works: The Strategic Logic of Nonviolent Conflict. New York: Columbia University Press.

Cohen, Jean L. and Arato, Andrew. 1992. Civil Society and Political Theory. Cambridge, MA and London: M.I.T. Press.

Cole, David. 2014. “The Three Leakers and What to Do About Them." New York Review of Books, February 6, 2014.

Collier, Paul. 2007. "Economic Causes of Conflict and their Implications for Policy." Unleashing the Dogs of War, ed. Chester A. Crocker, Fen Osler Hampson and Pamela Aall, 197-218. Washington, DC: United States Institute of Peace.

Collier, Paul. and Hoeffler, Anke. 2004. "Greed and Grievance in Civil Wars." Oxford Economic Papers 56 (4): 563-595.

Collins, Ronald K.L and Skover, David M. 2013. On Dissent: Its Meaning in America. New York: Cambridge.

Day, Barbara. 1999. The Velvet Philosophers. London: Claridge.

Falk, Barbara J. 2013. "Reflections of the Revolutions in Europe: Lessons for the Middle East and the Arab Spring," in Samizdat, Tamizdat and Beyond: Transnational Media During and After Socialism, ed. Friederike Kind-Kovács, Friederike and Jessie Labov, 281-315. New York and Oxford: Berghahn.

Falk, Barbara J. 2003a. The Dilemmas of Dissidence in East-Central Europe: Citizen Intellectuals and Philosopher Kings. New York and Budapest: Central European University Press. 
Falk, Barbara J. 2003b. "Post Communism's First Decade: A Primer for NonSpecialists." Canadian Journal of Political Science 36 (2): 417-437.

Fischer, Benjamin B. 2012. "Solidarity, the CIA, and Western Technology." International Journal of Intelligence and CounterIntelligence 25 (3): 427-469.

Foucault, Michel. 1980. Power/Knowledge: Selected Interviews and Writings, ed. C. Gordon. New York: Pantheon.

Friedrich, Carl and Brzezinski, Zbigniew K. 1965. Totalitarian Dictatorship and Democracy. $2^{\text {nd }}$ ed. Cambridge, MA: Harvard University Press.

Garton Ash. Timothy. 1999. The History of the Present: Essays, Sketches, and Dispatches from Europe in the 1990s. New York: Random House.

Gerson, Jen. 2014. "License to Mobilize: Experts ask Whether Resistant Groups Champion Rights or Undermine Law." National Post, Saturday October 18, A8.

Gray, John. 2007. Enlightenment's Wake: Politics and Culture at the Close of the Modern Age. London and New York: Routledge Classics.

Havel, Václav. 1991. Open Letters: Selected Prose 1965-1990. Trans. P. Wilson and A.G. Brain. London: Faber and Faber.

Habermas, Jürgen. 1994. The Structural Transformation of the Public Sphere. Trans. Thomas Burger. Cambridge: M.I.T. Press.

Hill, Christopher. 1980. The Century of Revolution: 1603-1714. London and New York: Routledge.

Healy, Thomas. 2013. The Great Dissent: How Oliver Wendell Holmes Changed His Mind-and Changed the History of Free Speech in America. New York: Metropolitan.

Hirschman, Albert O. 1970. Exit, Voice, and Loyalty: Responses to Decline in Firms, Organizations and States. Cambridge, MA: Harvard University Press.

Hobsbawm, Eric J. 1962. The Age of Revolution 1789-1848. London: Weidenfeld and Nicolson.

Jahanbegloo, Ramin. 2014. Introduction to Nonviolence. Basingstoke: Palgrave Macmillan.

Kazin, Michael. 2014. "Halfway There: Why the Left Wins on Culture and Loses on Economics." Foreign Affairs 93 (5): 47-56.

Kazin, Michael. 2011. American Dreamers: How the Left Changed a Nation. New York: Alfred A. Knopf.

Keane, John. 1998. Civil Society: Old Images, New Visions. Stanford: Stanford University Press.

Keane, John. 1996. Reflections on Violence. London: Verso. 
Kind-Kovács, Friederike and Labov, Jessie, eds. 2013. Samizdat, Tamizdat and Beyond: Transnational Media During and After Socialism. New York and Oxford: Berghahn.

Klehr, Harvey, Haynes John Earl and Vassiliev, Alexander. 2009. Alexander Vassiliev, Spies: The Rise and Fall of the KGB in America. New Haven and London: Yale University Press.

Klein, Naomi. 2014. This Changes Everything: Capitalism Vs. The Climate. New York: Simon and Schuster.

Klein, Naomi. 2008. The Shock Doctrine: The Rise of Disaster Capitalism. New York: Picador.

Klein, Naomi. 2000. No Logo: Taking Aim at the Brand Bullies. Toronto: Vintage. Konrád, George. 1987. Antipolitics. Trans. R.E. Allen. New York: Henry Holt.

Krastev, Ivan. 2014. Democracy Disrupted: The Politics of Global Protest. Philadelphia: University of Pennsylvania Press.

Kurklansky, Mark. 2006. Nonviolence: Twenty-Five Lessons from the History of a Dangerous Idea. New York: Modern Library.

Kuroń, Jacek. 1981. "Not to Lure the Wolves out of the Woods: An Interview with Jacek Kuroń.” Telos 47: 93-97.

Locke, John. 1965. Two Treatises of Government. Introduction and Notes by Peter Laslett. New York: Mentor.

Malleson, Tom. 2014. After Occupy: Economic Democracy for the Twenty-First Century. New York: Oxford.

Meredith, Martin. 2010. Mandela: A Biography. New York: Public Affairs.

Michnik, Adam. 1985. Letters from Prison and Other Essays. Trans. Maya Litynski. Berkeley: University of California Press.

Mill, John Stuart. 1978. Utilitarianism, On Liberty, Essay on Bentham, ed. Mary Warnock. Glasgow: Fount Paperbacks.

Morozov, Evgeny. 2011. The Net Delusion: The Dark Side of Internet Freedom. New York: Public Affairs.

Nepstad, Sharon Erickson. 2011. Nonviolent Revolutions: Civil Resistance in the Late twentieth Century. Oxford: Oxford University Press.

Northouse, Peter G. 2004. Leadership: Theory and Practice. Third Edition. Thousand Oaks, CA, London, and New Delhi: Sage Publications.

Piketty, Thomas. 2014. Capital in the Twenty-First Century. Trans. Arthur Goldhammer. Cambridge, MA: Harvard University Press.

Rosano, Michael J. 2003. "John Winthrop, John Cotton, and Nathaniel Niles: The Basic Principles of Puritan Political Thought." History of American Political Thought, ed. Bryan-Paul Frost and Jeffrey Sinkkenga 25-43. Lanham: Lexington. 
Roberts, Adam and Garton Ash, Timothy. 2009. Civil Resistance \& Power Politics: The Experience of Non-violent Action from Gandhi to the Present. Oxford and New York: Oxford University Press.

Sampson, Anthony. 2011. Mandela: The Authorised Biography. London: Harper Press.

Scott, James C. 1990. Domination and the Arts of Resistance: Hidden Transcripts. New Haven and London: Yale University Press.

Schell, Jonathan. 2005. Unconquerable World: Why Peaceful Protest is Stronger than War. London: Penguin.

Seligman, Adam. 1992. The Idea of Civil Society. Toronto and New York: The Free Press.

Sharp, Gene. 2010. From Dictatorship to Democracy: A Conceptual Framework for Liberation. Boston: Albert Einstein Institution.

Sharp, Gene. 2003. There are Realistic Alternatives. Boston: Albert Einstein Institution.

Sharp, Gene. 1973. The Politics of Nonviolent Action. Boston: P. Singer.

Shavit, Ari. 2013. My Promised Land: The Triumph and Tragedy of Israel. New York: Speigel \& Grau.

Skilling, H.G. and Wilson, Paul, eds. 1991. Civic Freedom in Central Europe: Voices from Czechoslovakia. London: Macmillan.

Skilling, H.G. 1989. Samizdat and an Independent Society in Central and Eastern Europe. London: Macmillan.

Sorel, Georges. 1910. Réflexions sur la violence. Paris: Rivère. 2e éd.

Stan, Lavinia, ed. 2009. Transitional Justice in Eastern Europe and the Former Soviet Union: Reckoning with the Communist Past. London and New York: Routledge. Strauss, Leo. 1952. Persecution and the Art of Writing. Glencoe: Ill.: The Free Press. Sunstein, Cass R. 2003. Why Societies Need Dissent. London and Cambridge, MA: Harvard University Press.

The Compact Edition of the Oxford English Dictionary. 1987. Three Volumes. Oxford, New York and Toronto, Oxford University Press.

Tucker, Robert C. 1978. The Marx-Engels Reader. Second edition. New York and London: W.W. Norton.

Thompson, E.P. 1980. The Making of the English Working Class. London: Penguin. Weber, Max. 1981. "Politics as a Vocation." In Max Weber: Essays in Sociology. Trans., Eds. and Introduction by H.H. Gerth and C. Wright Mills. New York: Oxford University Press. 
Winthrop, John. 1965. “Christian Charitie: A Modell Hereof." Puritan Politcal Ideas 1558-1994. Indianapolis: Bobbs-Merrill.

Yousafzai, Malala. 2013. I am Malala: The Girl Who Stood Up for Education and Was Shot by the Taliban. With Christina Lamb. New York, Boston, and London: Little Brown. 
Barbara Martin

\title{
History as Dissent: Independent Historians in the Late Soviet Era and Post-Soviet Russia: From "Pamiat" to "Memorial"
}

\begin{abstract}
This paper establishes a line of continuity between the Soviet, Brezhnev-era dissident historical journal Pamiat' and the post-Soviet human rights organization Memorial. It examines the differences and similarities of their histories, contexts of action, and goals.
\end{abstract}

\section{Introduction}

Rulers have often acknowledged the importance of mastering historical writing and quenching dissenting memories in order to reinforce popular allegiance to the regime or to forge a new consciousness of a people's past, present, and future. Nowhere was this better understood than in the Soviet Union, where the Communist leadership sought to exercise an absolute control over the past through a careful overseeing of both academic historiography and historical literature. As the subjection of official history to the regime had reached a peak under Stalin, his death triggered some momentous, if temporary, changes.

The official denunciation by General Secretary Nikita Khrushchev of Stalin's crimes at the Twentieth Party Congress of the Communist Party of the Soviet Union in 1956 constituted a major milestone in the process of de-Stalinization of Soviet society. This did not lead to a depoliticization of historical writing, however. Until Perestroika, history remained a carefully guarded sanctuary over which the State retained a quasi-absolute monopoly. This entailed both a restriction on the range of themes studied and a submission of historical writing to ideological and political imperatives defined by state and party organs.

While Khrushchev initiated a "thaw" which allowed for the publication of a number of articles, monographs, poems, and novels dedicated to hitherto taboo themes-such as the Gulag camps, political repression, and Stalin's wartime failures-his removal in October 1964 heralded a new freeze in official historiography and literature and a tightening of censorship (Markwick 2009). From then on, publications on sensitive issues of the past disappeared from presses, and alternative accounts of the Stalin era had to recede underground.

Still, despite the increasing likelihood of repression, some amateur researchers decided to pursue their exploration of the "blank spots" of Soviet history 
independently. Deprived of access to Soviet publications, these isolated voices circulated their writings in samizdat or published them in the West (tamizdat). ${ }^{1}$ They acted out of the ethical conviction that the truth about the Stalin era had to emerge, whether through the state or by individuals. Sometimes, this discourse was also tainted by political activism, as revelations about the past had consequences for the present and the future of the Soviet state and society.

My argument here is that, from the point of view of the state, such activity could not be considered "private" and constituted an open act of dissent, in and of itself political. As the totalitarian state sought to control all spheres of the lives of its citizens, Western distinctions between private and public spheres disappeared (Killingsworth 2012, 27). Therefore, circumventing censorship and the state monopoly on historical research was no trivial accusation. Regardless of the declared orientation of their writings, dissident amateur historians directly threatened a central attribute of the totalitarian state: its absolute control over the notion of "truth," including the truth about the past (Killingsworth 2012, 43). In this research, the notion of "dissent" or "dissidence" will be used to characterize such activities: these terms are used in a broad sense to name conscious acts in opposition to a regime's norms or rules of social behavior and considered by the regime as threatening or hostile and therefore incurring potential repression. ${ }^{2}$ Still, it should be underlined that the Soviet state's reaction to such behavior varied considerably over time, with frequent ebbs and flows, depending, inter alia, on changes of political personnel and variations in official policy.

This paper aims to demonstrate the specificity of the Soviet state's relation to dissident historical research, in comparison to the post-Soviet era. I will first provide a brief overview of the phenomenon of Soviet dissident historical research in the post-Stalin era, then examine in greater detail the case of the dissident historical journal Pamiat' ("memory"). In order to analyze both the differences and the continuities of the state's relation to independent historical research into the post-Soviet era, I will make a comparison with Memorial, the post-Soviet non-state organization that grew, during Perestroika, from Pamiat's roots, with an

1 The term samizdat designates typed copies of non-authorized texts circulating underground.

2 This definition is inspired by one provided by former Soviet dissidents and members of Pamiat's editorial committee, Aleksandr Daniel' and Larisa Bogoraz (1993, 147): "Any conscious act in opposition to the regime and violating certain (open to some degree of variation, depending on the place, time and circumstances) 'given' limits of social behavior. The criterion here is the possibility of repressive (in the broadest sense of this word) reaction on the part of the authorities." 
overlap of both research themes and personnel. Despite these continuities, I argue that there are substantial differences in the political and ideological contexts in which they appeared and operated. Unlike Pamiat', Memorial was able to adopt organizational forms, and has been acting in a framework, characteristic of civil society activism in democratic or mildly authoritarian societies, encountering, for most of its existence, hostility, but not outright repression, from the state.

\section{"Pamiat"”: A Late Soviet Case of Dissident Historical Research}

\section{Dissident Historians as a Social Phenomenon}

In contrast to the near absolute totalitarian control of Soviet society in the Stalin era, the late 1950s and early 1960s allowed for the emergence of a semblance of a private sphere escaping, or seeking to escape, the control of the state and security organs. This new, relatively narrow breathing space, coupled with Khrushchev's destalinization policy, constituted the necessary preconditions for the emergence of dissident historical research. Enthused by the radical decisions of the TwentySecond Party Congress and the relaxation of censorship that presided over the publication, most prominently, of Aleksandr Solzhenitsyn's Gulag camp novella One Day in the Life of Ivan Denisovich (1961), a small number of individuals took upon themselves the task of writing unofficial histories of the dark pages of the Soviet past. Deprived of any access to state archives, they decided to use those primary sources that were readily available and had remained hitherto unexploited, in particular oral testimonies. However, after Khrushchev's removal, they were faced with an increasing reluctance on the part of the regime to continue and deepen the process of destalinization, and had to turn to alternative channels of publication, whether tamizdat or samizdat. Therefore, the context dictated both the methods of research and the means of publication of these works, but also, more often than not, their content, ideological orientation, and tone, which differed strikingly from those of official Soviet historiography.

This was the time, in particular, when the two most prominent studies of Soviet dissident historiography were conceived and written. Undoubtedly the most notorious of the two was Solzhenitsyn's Gulag Archipelago (1973). This work, which the author dubbed "an experiment in literary investigation," retraced in detail the long history of the Gulag camps, based on hundreds of testimonies of former Gulag inmates and on Solzhenitsyn's personal experience. The ground-breaking nature of this research, which incurred the wrath of Soviet authorities and caused the eviction of Solzhenitsyn from the Soviet Union, could hardly be overstated. Although many have criticized it from a factual as well as an ideological point of 
view, it remains the first study of this kind, and arguably the most potent collective testimony of half a century of history of the Gulag camp system.

The second most well-known work by a dissident historian was Roy Medvedev's monumental study of Stalin and Stalinism Let History Judge (1972). Conceived of as the author's contribution to the democratization of Communism, it tackled the questions of the origins, causes, and consequences of the phenomenon of Stalinism, which Medvedev, in line with Khrushchev, considered as a distortion of the Party's ideological line. Although Medvedev's study was criticized in the West for its avowedly socialist perspective, the Western scholarly community welcomed the publication of this first independent historical study on Stalinist repression written within the Soviet Union and based on hitherto unknown testimonies of old Bolsheviks - veterans of the Revolution who had occupied high positions in the state and party apparatus before being repressed by Stalin.

Both of these cases display a common pattern of relations with the state, characterized first by a search for accommodation and collaboration, encouraged by Khrushchev's "Thaw," then followed in the second half of the 1960s by a turn towards increasing confrontation and repression under Brezhnev. Yet the turn towards illegality was not inevitable. Rather, it resulted from a gradual narrowing of available options over time. Twelve years before being branded as a traitor, Solzhenitsyn had met with national acclaim following the publication of his first short stories in the Soviet journal Novyi Mir. However, starting from 1964-5, Solzhenitsyn faced increasing state hostility and KGB harassment, and his novels Cancer Ward and The First Circle were rejected by Soviet censorship. It was the failure of these attempts that prompted him to turn to samizdat and tamizdat and radicalized his position away from a compromise with the regime. ${ }^{3}$ This spiral of mutual estrangement between Solzhenitsyn and the Soviet state explains the culmination constituted by the publication of The Gulag Archipelago, which the dissident Larisa Bogoraz has described as an "indictment against the Soviet regime" (Bogoraz 2009, 210). As a result of his increasing outspokenness, Solzhenitsyn faced exclusion from the Writers' Union in 1969, before being arrested and forcefully exiled from the country and deprived of his citizenship in 1974.

Similarly, Medvedev voluntarily submitted the manuscript of his book to the Central Committee of the CPSU in 1964 to get, if not official support, then at least tacit approval-but these illusions were dispelled in the following years. After the

3 For these two novels, published in the West in 1967 and 1968 respectively, Solzhenitsyn received the Nobel Prize of Literature in 1970. In his own country, however, only a few of his short stories were published, and he failed to be awarded the Lenin Prize for One Day in the Life of Ivan Denisovich in 1964. 
Soviet intervention to crush the Prague Spring in August 1968, Medvedev's brand of "democratic socialism," reminiscent of Czechoslovak "socialism with a human face," could not but face repression. By August 1969, he had been expelled from the Party-solely for his authorship of an unpublished manuscript. It became clear that the notoriety procured by the publication of Let History Judge in the West, while potentially incurring further repression, could also protect its author. And indeed, while he narrowly escaped arrest by hiding in the months preceding publication, after 1972, Medvedev was able to pursue, virtually unimpeded, a career as an independent historian, regularly publishing political and historical studies abroad (Medvedev 1980, 33).

Although both works may arguably be described as political statements, it was not merely the political content of these works that was deemed threatening by the regime, but, more broadly, the very fact of undertaking independent historical research outside of the framework of state-controlled scientific institutions, as shown by the example of the historical journal Pamiat'.

\section{The Case of Pamiat'}

The dissident historical journal Pamiat' appeared towards the end of the Brezhnev era, partly in continuity with and partly in reaction to the dissident historical works discussed above. It represents a unique case of a Soviet dissident historical periodical publication, authored by non-professional historians. Although it shared with previous dissident historical research a striving to uncover "historical truth," its authors belonged mostly to the post-War generation, who had grown estranged from state ideology.

In 1975, the Soviet dissident Larisa Bogoraz sent an open letter of protest to Iurii Andropov, head of the State Security Committee, demanding the opening of the archives of the KGB and threatening to collect and publish testimonies and materials about the history of political repressions, which had affected so many members of her family, both in the Stalin and post-Stalin eras, as well as herself. ${ }^{4}$ (Tolstoi and Gavrilov 2011). A few months later, her call was unexpectedly answered by the visit

4 This letter was a follow up to the "Moscow Declaration" authored by Andrei Sakharov and other dissidents after Aleksandr Solzhenitsyn's expulsion, in February 1974. Bogoraz had been arrested for her participation to a demonstration on Red Square against the Soviet occupation of Czechoslovakia, in August 1968, and had spent four years in exile in Siberia. In addition to her grandfather and several relatives, who had suffered from Stalin era repression, her first husband Iulii Daniel' and her second spouse Anatolii Marchenko were also imprisoned in the Brezhnev era. 
of Sergei Dediulin, a young man from Leningrad who invited her to take part in a project of underground historical publication, which he and his friends Arsenii Roginskii and Valerii Sazhin were elaborating (Bogoraz 2009, 211).

A common love for forbidden Russian literature and samizdat, as well as a free spirit and the willingness to escape the stifling climate of the Brezhnev era through independent projects of all kinds were probably the main ingredients of the three young men's friendship. Despite an outstanding academic record during his studies with the famous semiotician Iurii Lotman at Tartu University (Estonia), which predisposed him to a brilliant academic career, Roginskii failed to become enrolled as a doctoral student in 1968 and had to move back to Leningrad. Yet he did not renounce his calling and decided to conduct historical research independently. As the son of a victim of political repression - his father had survived a first incarceration under Stalin, only to die after his second arrest, in 1951-Roginskii was born and raised in internal exile. Growing up in the 1950s, he had begun early on to grasp the history of political repressions and resistance to the Soviet state by interrogating neighbors who were Gulag camp returnees. From this interaction with survivors of various oppositions to the regime grew his interest for the history of the nineteenth century revolutionary movement in Tsarist Russia, on which he published several articles (Ferretti 1993a, 82). In 1973, after the scandal surrounding the trial of Petr Iakir and Viktor Krasin, two dissidents who had betrayed their peers, he developed an interest in the conduct of dissenters of all eras in the face of repression:

I obtained the address of an old Menshevik woman. She gave me the address of others. I began to visit them, during the summer holidays I travelled to other cities, visited old people's homes, where some of them lived, I asked them about the 1920s' underground and began, on this basis, to compile a dictionary of Socialist Gulag prisoners. (hro.org 2006)

Roginskii thus belonged to what one of his former teachers would later describe as "the lost generation of scholars" (Gasparov 1981): lacking an official affiliation, he faced countless restrictions and obstacles in his work as an independent historian - a category unforeseen and unwelcome in a totalitarian state. He made a living through various minor jobs, as a tourist guide, librarian, and then as a teacher of Russian literature in an evening school-a position, which left him enough free time to work on his personal research projects on the side. Soon, he recommended this convenient job to his friend Sergei Dediulin, a former chemist and self-taught specialist in Russian literature (Dediulin 2013). Involved in smallscale underground literary publications starting from his student years, Dediulin had also become a passionate amateur bibliographer: among his countless projects was a bio-bibliographical dictionary of Soviet dissidence and an anthology of 
Anna Akhmatova's poetry. In the course of these activities, he had encountered numerous dissident writers and, with his friends' active support, had started to assemble an archive of samizdat (Sabbatini 2004; Dolinin et al. 2003a). He was actively supported by his friend Sazhin, who worked in the manuscripts archive of the Leningrad Public Library-a position that allowed him to explore freely the personal papers of early twentieth century writers, which fascinated him. Sazhin had met Roginskii during a student conference at Tartu University, and looked up to this talented and charismatic peer with respect and admiration (Sazhin 2014).

In 1975, the inventive Dediulin came up with the idea of publishing a literary samizdat journal devoted to non-official Russian literature-an idea Sazhin found promising. When they submitted their proposal to Roginskii, he expressed his support, but suggested a historical orientation. Unpublished primary sources, such as Gulag camp memoirs and other sources of historical interest were readily available from the Public Library's manuscript archives, where Sazhin could safely copy documents during his worktime (Sazhin 2014).

For the three friends, just as for Bogoraz, the recent publication of The Gulag Archipelago constituted a strong impetus for further research on Stalin-era repressions. For Dediulin, the publication of Solzhenitsyn's work was akin to a "Big Bang"; it opened new, unheard of spaces in their imaginations. They understood that beyond the scope of the book lay huge potential sources of historical material to be explored, readily available and yet hitherto unexploited (Dediulin 2013). Roginskii considered the book as "one of the most important points in our life"-although he disagreed with Solzhenitsyn's nostalgic views on an eternal and pure Tsarist Russia destroyed by godless Bolsheviks. Roginskii wished to explore the past in all of its complexity, without polemics, simply by presenting facts with commentaries, from across the whole political spectrum: "we were certain that only in this polyphony could one hear the truth" (hro.org 2006).

In the stifling climate of inertia of the late Brezhnev era, the prospect of undertaking such an exploration represented both a welcome breath of fresh air and a dangerous act of rebellion, which they understood could cost them dearly. Moreover, the sustained effort, energy, perseverance, and personal courage required to create, manage, and maintain undercover a tamizdat and samizdat historical publication were such that no equivalent project had so far come into being in the Soviet Union, although many probably shared similar aspirations (Dediulin 2013). Yet they willingly pursued the project, which they conceived of as rigorously academic in form and ideologically neutral in content (Pamiat' 1978, 1:IX-X).

The collective was completed by the addition of two Leningrad-based friends of Dediulin, the chemist Aleksandr Dobkin and the schoolteacher Feliks Perchenok, 
who researched the history of the Soviet Academy of Sciences in his free time. The initial academic orientation of the journal was altered by the addition of a new Moscow-based nucleus, gravitating around the dissident Larisa Bogoraz and her son Aleksandr Daniel', and joined later by Aleksei Korotaev and Dmitrii Zubarev. The dedication of the journal's first issue to the political prisoners Gabriel' Superfin and Sergei Kovalev (the former a close friend of Roginskii's) testified to this second "dissident" identity. As for professional historians, their participation in the publication was initially limited to the enthusiastic support and enlightened advice of Mikhail Gefter, a retired dissenting historian. Over time, however, the team also benefitted from consultations with other specialists (hro.org 2006).

The first issue, released in samizdat in 1976, contained a foreword laying out the objectives of the publication and calling for contributions. Inspired by the fruitful discussions of Roginskii with Gefter, it was put into words by Daniel': it began by describing the climate of amnesia, which had taken hold of Soviet society and against the background of which Pamiat' ("Memory") emerged:

"Forgetting" is here not just a selectively applied device, no, it is an obligatory rule of any historical research. Deviations from it are punished, and the historian himself, if he acts within the official framework, is a custodian of this unshakeable law. The result is not just the constant rewriting of history according to yesterday's circumstances and today's personification of power, but the perpetual conservation of a zone of silence. (Pamiat' 1978, 1:VI)

Although the access to archival sources was a problem, the state-imposed silence did not amount to ignorance. "Our main historical secrets are of a special kind. Millions of people have been led into these secrets... Millions of witnesses, and many of them are still alive! No historian ever had such abundant material at hand." Personal archives, memoirs and other personal sources represented "huge reserves of historical memory." The authors deemed it their duty to "save from oblivion all historical facts and names doomed today to death, disappearance, first and foremost the names of the deceased, persecuted, slandered ..." (Pamiat' 1978, 1:VII-IX).

They called on readers, in the Soviet Union and abroad, to send them "memoirs, diaries, letters, oral testimonies, official documents... unpublished manuscripts... articles, essays, reviews, bibliographies, any materials about the history of culture, religion, science, politics, social thinking," regardless of the political orientation of their authors. However, the authors noted that, despite their striving to maintain high scientific standards, the lack of access to some archives and restricted library reserves might impede the verification of some of their hypotheses. Still, the format of a periodical publication would permit an in-depth 
exploration of some topics across several issues, including, but not restricted to, the Gulag theme, and allow editors to "enter into dialogue with readers" (Pamiat" 1978, 1:VIII, IX).

Conceived of as a tamizdat publication from the beginning, Pamiat' was represented in the West by Natal'ia Gorbanevskaia, a well-known dissident and founder of the samizdat information bulletin The Chronicle of Current Events, who had recently emigrated to the West. She supervised the publication of the first Pamiat' in 1978 in New York. However, after a conflict with the editor Valerii Chalidze, she turned to another friend of the group, Vladimir Alloi, who took over the edition in Paris, releasing four other issues-each a thick volume of over five hundred pages.

In terms of the journal's content, the five issues covered a very broad range of subjects, with a time frame spanning the years 1900 to 1968 - the date of the first publication of The Chronicle of Current Events, the dissident news bulletin documenting contemporary political repressions. Expanding on its original Gulag orientation, Pamiat' explored the history of a political terror that had affected all spheres of Soviet life, from literature to sciences and religion. By throwing light upon those pages that had been consciously removed from official history, the authors of Pamiat' established their own alternative histories. Yet theirs was not solely a history of victims; it was also one of opposition to the state (Ferretti 1993a, 83-84) - hence their collaboration with the Menshevik Dmitrii Batser and the post-Stalin era political prisoners Revol't Pimenov and Veniamin Iofe, or the dedication of a section of the third issue to the dissident Anatolii Marchenko. Therefore, although the focus was not avowedly political, the Soviet state could hardly close an eye on a publication that gave a voice to its opponents and victims.

Except for Roginskii, who was the author of several historical publications, none of the redactors of Pamiat' could be described as professional historians. Still, they were far from being foreign to the research trade and all belonged in some way to the intelligentsia, whether they were trained in natural, social or human sciences, or self-taught. Moreover, they made up for the lack of access to archives and of professional research skills with enthusiasm and resourcefulness, spending their free time in libraries, from which they had learned to extract every scrap of information available (Zubarev 2013).

Although members of Pamiat' could work individually on tasks assigned or chosen, the publication was fundamentally a collective undertaking; authorship of one piece was never fully individual, as the whole collective participated in turn in writing, commenting on, editing, and introducing each piece. The definition of the format and orientation, as well as the selection of content for the issue, was also the result of common discussion during editorial meetings in Leningrad and 
Moscow. In the editorial team, Roginskii occupied the position of "first among equals." Although he was based in Leningrad, from 1977 to 1981, he spent the three summer months in Moscow, working on Pamiat' with his co-editors, in various apartments lent by sympathizers and friends (Dediulin 2013; Zubarev 2013). Apart from authoring, prefacing, or editing many of the publications himself, he was also the "wise strategist" who knew how to manage the team's "human resources" and ensure the successful publication of the journal, playing his cards astutely in what turned out to be a duel with the KGB (Sazhin 2014).

The conditions of the time dictated conspiracy measures and the use of extreme caution. Some memoirs were anonymized to prevent the identification of their origin or author (Sazhin 2014). Editors and contributors also had to hide behind pseudonyms, except for a few, who rejected anonymity, either because they had a history of repression behind them and had forsaken fear (Revol't Pimenov, Evgenii Gnedin), because they were retired (Mikhail Gefter), or because they were about to emigrate (Mark Popovskii) (Zubarev 2013). Often, to ensure that the author would not be identified, two sets of initials or pseudonyms stood under one piece. Nevertheless, Dediulin affirms in retrospect that many pseudonyms chosen must have been transparent for the KGB, as the young friends were not experienced conspirators (Dediulin 2013). Bogoraz, who was a well-known dissident, took many precautions to avoid betraying her colleagues when visiting them in Leningrad (Bogoraz 2009, 214; Dediulin 2013). Yet even before the first issue came out, the State Security services knew of its existence and had identified at least some of its authors (Sazhin 2014).

Repression began with house searches. The first was at Roginskii's and his mother-in-law's apartments in February, 1977. This was followed by a "prophylactic warning" issued by the KGB organs in June (Wishnevsky 1981). In March 1979 , the State Security organs performed new searches at Roginskii's, Korotaev's mother's, Dediulin's, Sazhin's, and Daniel's places. Roginskii, Dediulin, and Sazhin were called for interrogations in March, while Korotaev was called in April, and Daniel' in July (hro.org 2006). At the KGB's demand, Roginskii was fired from his teaching position for "the commission by a worker, fulfilling the functions of an educator, of an immoral act incompatible with his continuing to perform that work." When he appealed this decision with a tribunal, he lost his case and the verdict confirmed that "the books confiscated from Roginsk[ii] do not meet the standards of literature by the KGB," justifying his dismissal (hro.org 2006). As for Dediulin, he lost a vast quantity of material, seized during the search, including his bio-bibliographical dictionary of Soviet dissidence, and was forced, like Roginskii, to resign from his teaching position. In reaction, Bogoraz circulated a 
declaration of support for the young researcher, giving publicity to his work and denouncing an "attack on our memory [pamiat']" (Ianovskii 2010, 148). Gorbanevskaia launched a campaign of protest in the West, which may have protected Dediulin and extended the life of Pamiat' for two years (Sabbatini 2004, 5-6; Dediulin 2013).

However, the KGB continued to gather information about the editors of the journal and to harass the group. In March 1981, Dediulin was forced to leave the country (Dolinin et al. 2003a). In April, Roginskii also faced an ultimatum to emigrate. He did not hurry to comply with the demand, however. In June, the Public Library in Leningrad deprived him of his reader's card for "use of archival material for 'illegal' publication abroad." Finally, on August 12, 1981, he was arrested at his family dacha at Ust'-Narva, in Estonia (Beshenkovskii 1981; Dolinin et al. 2003b). He stood accused of falsification of letters of accreditation to get access to archives.

From then on, a large-scale campaign began in Roginskii's defense in the West, sustained to a large extent by Sergei Dediulin, by then based in Paris. The latter did not reveal Roginskii's participation in Pamiat', as this was not the count of indictment chosen by the authorities, and such a revelation might have endangered him further. Instead, Dediulin waged a successful campaign around the image of Roginskii as an independent historian, who, despite not being a dissident, "still inspired panic to local authorities simply because of the independence of his intellect" (Dediulin 1982). Among the open supporters of Roginskii were Soviet émigré and Western writers Lev Kopelev (Kopelew 1981), Vladimir Voinovich, and Heinrich Böll ("Solidarität mit Roginskij" 1981). The international community of historians also became mobilized, and the "International Committee of Historians in Defense of Arsenii Roginskii" collected over five hundred signatures of prominent researchers in his support (Dediulin 1982).

On November 25, 1981, Roginskii's trial opened in Leningrad. He was accused under article 196, part 2 of the Criminal code, punishing "forgeries, the fabrication or sale of falsified documents, stamps, seals or forms" by a sentence of up to five years of imprisonment. As much as the count of indictment appeared farfetched, the conduct of the trial could hardly have convinced Western observers. Key witnesses such as Vladimir Pugachev, a Professor of Saratov University, and Samuil Lur'e, editor from the newspaper "Neva," who had initially denied providing Roginskii with letters of accreditation, partly recanted during the trial, and showing support for him, implied that they might have been complicit. Only after a third, additional expert report was commissioned by the tribunal could Roginskii's guilt eventually—and unsatisfactorily—be demonstrated. Nevertheless, the initial 
accusation was reinforced by the testimonies of employees of various archives where Roginskii had done research, who claimed that documents published in Pamiat' came from their archival fonds, to which only Roginskii had been granted access (RFE Research 1981). In the final accusation, the goal of Roginskii's activities in the archives was described as the "publication of archival documents in foreign editions" (Sobranie Dokumentov Samizdata 1981). Thus although Roginskii was not formally accused of being the editor of Pamiat' - which would have constituted a political, rather than a criminal accusation - the essence of his condemnation lay in his "violation of the monopoly of history" (M.H. 1982, 120). For this, Roginskii was condemned, on December 4, 1981, to four years' imprisonment. This was close to the maximum sentence offered by law.

Sazhin recorded, and Dobkin transcribed, Roginskii's last declaration at his trial and then dictated the text over the phone to Dediulin, who made it public in the West (Dediulin 2013; Roginskij 1982). As during the whole trial, Roginskii refused to discuss the matter of his guilt and instead attacked the whole system that forced historians to bend the law in order to work independently. Any serious researcher of the Soviet past needs to work with archival material, he claimed. Yet in the Soviet Union, only historians accredited by Soviet research institutions or press for specific projects could get such authorizations; indeed, even if they did, they could be arbitrarily denied access to specific documents or archival fonds. The result was a narrowing of the themes studied by historians, an alienation of independent researchers, and, ultimately, a distortion of history. Roginskii called for a new system to be instated, according to which interviews would replace letters of accreditation, and restrictions on access to documents would be lifted. Only this would create the conditions ensuring that researchers would not have to "contrive" to get accreditations or humiliate themselves further by resorting to forgeries. Finally, Roginskii set out to prove the absurdity of the distinction made by the prosecution between unauthorized publication of an archival document in a foreign journal and that document's Soviet publication.

A document, if it is reproduced faithfully and commented objectively, remains a document independently of where and by whom it is published-because there is only one Russian culture, there are historical and literary archives, which belong to this culture. And only the free study of these archives and their free publication will help us learn the truth about our past. (Sobranie Dokumentov Samizdata 1981, 12)

Interestingly, the connection to Pamiat' was made even in the Soviet media: on February 12, 1982, an article appeared in the newspaper Vechernii Leningrad: "How 'canards' are born, or the tale about a 'talented researcher, 'famous writer', and so on" (Grigor'ev 1982). After mentioning a "revolting" case of library book theft, the 
article turned to the case of Roginskii, whose evil deeds had caused damage "beyond measure" to Soviet society. The "criminal activity" of the historian was mentioned in a somewhat fantastic account of how a copy of Pamiat' had been discharged by a foreigner before going through customs. Upon examination of the copy by the Public Library staff, it was revealed that the journal contained documents from their archives. "How could they end up in a U.S. publishing house? [The staff] clarified who had received access to them. They found out it was Roginskii” (Grigor'ev 1982). Then followed a detailed account of his reprehensible activities, from his early house searches to his alleged forgeries. The question of the complicity of Pugachev and Lur'e was also raised: the latter displayed astonishing amnesia and the former sought to demonstrate that Roginskii was enrolled as a doctoral student in his institution. However, Roginskii's most vocal supporters were, obviously, "the 'ideologists' from the emigrant scum" who had instigated a campaign that found widespread support with the Western media and public opinion. "How could they let go of such a 'titbit'? How could the West not make Roginskii, an average crook, 'a fighter for human rights in the USSR' (don't laugh!), 'a scientist with a world reputation', 'a worldwide famous Russian historian!'” (Grigor'ev 1982)

Such rhetoric was a familiar denigration device used against dissidents who attracted attention from the Western media. However, the campaign did not go any further: indeed, Roginskii was unknown to the Soviet public, as was often the case with low profile dissidents, any further media attention could only result in raising undue public interest in his activities.

The history of Pamiat' shows quite clearly that independent historical research was not tolerated by the Soviet regime, which still sought to exercise a totalitarian control over society. It was not a question of whether the material published by independent historians was political and threatening to the regime. Rather, the creation of an independent historical journal published in samizdat and tamizdat violated several state "monopolies," most prominently those on historical research and publication. Although these were not official monopolies, Soviet intellectuals had known since the infamous 1966 trial against the writers Iulii Daniel' and Andrei Siniavskii that publishing "anti-Soviet" works abroad could result in a seven-year prison term. Roginskii and his friends were aware they were crossing dangerous boundaries and exposing themselves to repression, but they knowingly circumvented these monopolies. Therefore, I argue, their actions qualify as dissent.

Nonetheless, in contrast with their predecessors, such as Solzhenitsyn and Medvedev, their actions did not amount to a political struggle, nor was it in and of itself a posture of protest in relation to the regime. Undoubtedly, each member of the collective conceived of his/her involvement with Pamiat' in a different way, 
but perhaps what they shared was an idealistic striving to write as they pleased, independently of the regime-a posture traditional of the old Russian intelligentsia (Tolstoi 2012). Dediulin and Sazhin, who were in their late twenties when Pamiat' was created, also shared with the younger generation, born after the war, a feeling of estrangement from official ideology, which went along with a deep interest for their country's culture and history. Sazhin confessed he had long been "anti-Soviet," but had acted out of ethical rather than political motives, in addition to a thirst of knowledge and a strong interest for archival documents (Sazhin 2014). Far from wanting to emigrate, Dediulin wished to escape constraints and bans imposed by the regime, not through open protest or provocation, but instead by avoiding attracting undue attention unto himself. "We needed to work, read books, read forbidden books, read archives, look for private archives, and talk with people," he recalls (Dediulin 2013). And this required remaining out of the KGB's limelight.

Yet this proved impossible in the long run: by publishing abroad, even under pseudonyms, the editors of Pamiat' had chosen to step into the open, in contrast to generations of Soviet intellectuals who had quietly written "for the drawer," and the Soviet state could not ignore this act of resistance. With publicity came repression, and, crucially, Roginskii's "Last Word" took notice of this unwilling change of circumstances, this forced transition from the status of historian to that of dissident. By turning to a position of outright defiance towards the system that condemned independent researchers to break the law or renounce their activity, Roginskii initiated a shift towards open militancy, which would lead in later years to his active involvement with the organization Memorial.

Still, in the long run, and in the face of repression, Pamiat' was broken. While Roginskii was sent to a labor camp, the KGB interrogated other members of Pamiat' who remained in the USSR. Although the repressive organs did not proceed to further arrests, they kept a close watch on the group, and in 1985, the State Security made it clear to Dobkin and his friends that there could be no question of publishing the sixth issue of the journal, which Dobkin had sent to the West and was being prepared for publication. If it came out, Roginskii would be given a new sentence, the KGB warned. The group had no choice but to obey. This material was nonetheless published in the new historical journal Minuvshee, created in Paris by Alloi in 1986, and conceived of as the continuation of Pamiat' (Alloi 1998, 198; Igrunov 2005). As for Roginskii, he was liberated on August 12, 1985 (“Spravka Nº21634, SSSR Ministerstvo Vnutrennykh Del” 1985). By that time, three Soviet General Secretaries had gone to their graves and a fourth one, Mikhail Gorbachev, was about to launch his revolutionary policy of Glasnost. 


\section{"Memorial" and Post-Soviet Independent Historical Research: Anti-Stalinist Activism in Post-Soviet Russia}

\section{The Birth of Memorial}

In contrast to the strict taboos of the totalitarian Brezhnev era, which labeled as anti-Soviet any independent exploration of the past, Russian post-Soviet society has been characterized by a less unequivocal attitude to the memory of past crimes and to independent historians who have sought to perpetuate it. The case of Memorial, a human rights organization born during Perestroika from the seeds sown by Pamiat', reveals these differences of context and attitude. As I will argue, this new context, starting with Perestroika and increasing after 1991, has allowed for the birth of a kind of anti-Stalinist activism that could not have taken place in the Brezhnev era. While the anti-Stalinist impetus for the creation and continued existence of Memorial is similar to that which gave birth to late Soviet dissident historical research, the form taken by Memorial testified to important changes in the political and, by extension, memorial climate.

The history of the birth of the Memorial movement during Perestroika is well-known: the initial impetus was provided by a petition of former political prisoners and their descendants to erect the monument to victims of political repression promised by Khrushchev in 1961 (Smith 2009; Ferretti 1993b). But the construction of this memorial could not be an end in itself, and the members of the newly-created organization understood that Memorial "should transform into an all-Union social organization, whose main task should be the restoration of the historical memory of the people, in autonomy, independent from the state and state institutions" (Mezhdunarodnyi Memorial 2014a).

In the context of Glasnost, social interest in the repressed past reached its peak, and the Memorial movement grew in size. Local branches sprouted up throughout the country. As it sought to build its support-base within society, Memorial faced the difficulty of negotiating a legal status with the authorities, attempting to strike an intermediary course between incurring debilitating repression and risking cooption by the regime. The growing popularity of Memorial presented the Communist Party with a new challenge: not only did the birth of civil society break the Party's totalitarian monopoly over social and political institutions, but the emphasis on the memory of political repression, despite being in line with the new policies of Gorbachev, was still potentially threatening to the legitimacy of the regime. In order to give an official status to the movement, a founding conference was convened in Moscow in January 1989. Yet it took another year before the organization was granted official registration, with Gorbachev's support (Roginskii 2014). 
Former barriers were progressively unravelling under the combined pressure of public opinion and the reforming leadership. What seemed previously utopian was becoming reality. But even as Gorbachev himself encouraged explorations of Soviet history, Memorial insisted on retaining its independence, refusing to entrust the people's memory to "a state which, during its whole history, only lied about the present and falsified the past" (Mezhdunarodnyi Memorial 2014a).

By May 1989, the creation of what would become the "scientific historicaleducational center Memorial" was already on the way. Roginskii presented the future organization in these words:

Progressively, in the course of discussions and numerous debates, another, deeper and broader idea emerged: that it was necessary to create in Moscow [...] a memorial complex in memory of victims of political repressions, which would have to include, not just a monument $[. .$.$] but also a scientific-informational and educational center, which would$ in its turn contain an archive, a museum and a library accessible to all (that is the most important notion here, accessible to all). Only such a center with information, with data about victims could [...] become an effective, a real factor on the long term in the struggle with Stalinism, and I mean Stalinism in the broadest sense of the word. (Alekseeva 1989)

The very definition of the term "Stalinism," and correspondingly of the scope of the phenomenon, was the object of bitter discussion at the Memorial preparatory conference in October 1988. On this definition would depend not only the scope of research, but also the general orientation of Memorial. While moderates were in favor of a restrictive time frame limited to the 1927-1953 period, radicals called for a much broader scope (Ferretti 1993b, 352-353). Roginskii belonged to the latter camp and defined Memorial's goal as "the restoration of historical truth on the crimes of Stalinism, on the illegality of terroristic methods of state government, the study of its causes and consequences, the contribution to the recognition of the crimes of Stalinism, of crimes against humanity" (Alekseeva 1989). These objectives were in line with the general process of democratization and testified to the entanglement of two struggles inherited from the dissidence of the 1960s and 1970s: anti-Stalinism and human rights defense. Indeed, studying totalitarianism in the past went hand in hand with opposing its resurgence in the present (Roginskii 2014). Therefore, Memorial's mission evolved into two broad directions, intrinsically intertwined from the beginning: a historical direction, focused on the study of the history of political repression, which constituted the natural continuation of the work of Pamiat'; and a human rights defense direction inherited from the struggle of past dissidence. Complementary missions were the education of civil society and the material and legal support of victims of political repression and human rights abuse (Mezhdunarodnyi Memorial 2014b). Roginskii recalled that "some proposed that we become a research institute, others, a [political] party, 
but we decidedly turned away from either of these options. Our basic directions, historical-educational and human rights defense, were interrelated, and, what is important, ideologically connected: we consider history through [the prism of] law and law with the help of history" (Roginskii 2014). The heritage of the dissident era, with the prominent ethical values assumed by the struggle for the "restoration of historical truth" and anti-Stalinism, was thus central to the goals and values of Memorial from the very beginning. However, this dual orientation was not unproblematic in Memorial's relations with the state, both before and after the fall of the Soviet Union, and has conditioned the current official hostility towards the organization.

\section{Memorial and Pamiat': Continuities and Differences}

The shift from dissident historical research to civil society activism was prepared and conditioned by the changes of Perestroika, but it did not affect all former members of Pamiat' to an equal degree, although all of them continued, in some way, to be active in the field of independent historical research. For Roginskii, joining Memorial was a natural step:

It was in the Spring of 1988. I had already heard previously that a group had appeared, which collected signatures on the question of a memorial to the victims of Communist repression. However, I found out that they were also collecting information, that they were preparing a questionnaire for former prisoners. And in general, their idea was not only about a monument, but [more broadly] about memory: archives, a museum and a library about repressions. The four of us joined; Larisa [Bogoraz], [Aleksandr Daniel'], Sergei Kovalev and me. (hro.org 2006)

Daniel' and Roginskii became two of the pillars of the "scientific historicaleducational center Memorial": the former, until 2009, as the head of the research program dedicated to the history of dissent in the Soviet Union (Mezhdunarodnyi Memorial 2014c), the latter as the head of the organization since 1996. In the first years of the new regime, Roginskii acted as an expert for both the "Committee of the Supreme Soviet of the Russian Federation for Human Rights" and the "Commission of the Supreme Court of the Russian Federation for the transmission of the archives of the CPSU and KGB into state conservation and for the rehabilitation of victims of political repressions" (Dolinin et al. 2003b, 317). Finally, Korotaev and Zubarev also joined Memorial, one in the field of human rights defense, the other focusing on the history of dissidence.

However, others did not perform a turn towards activism and continued to pursue independent research as they had before. Dediulin remained in the West. Sazhin, estranged from the group, pursued independent research on the 
history of literature. Although Perchenok wrote a project for the creation of the "informational-scientific center Memorial" in 1989 and tried to obtain the opening of archives on his favorite research theme, the history of the Academy of Sciences, he died in 1993, leaving behind but a few published articles (Dolinin et al. 2003c; Dobkin and Sorokina 1995). After Roginskii's arrest, Dobkin redirected his attention towards Minuvshee, Alloi's Paris-based historical journal conceived of as the continuation of Pamiat'. When the publication was transferred to Russia, he became the informal chief editor of the journal until his death in 1998 (Dolinin et al. 2003d).

These two diverging paths taken by former Pamiat' members underline the differences of context between the Brezhnev era and Perestroika and the postSoviet era, but also the differences in their personalities. Larisa Bogoraz and her son Aleksandr Daniel' had been human-rights activists before joining Pamiat', and their renewed activism with Memorial was a logical outcome. So was it for Roginskii, who had willingly faced imprisonment and had stood up at his trial to call for the freedom of historians. With the onset of democratization, the cost of involvement decreased, and the potential benefits in terms of social impact increased considerably. Having conducted research in conditions of clandestinity, under threat of repression, they could now collect historical material virtually unimpeded, reach much broader audiences, and even try to influence political decision-making. Also, given the relative lack of political support for a deepening of the historical enquiry into and public acknowledgment of past crimes, the antiStalinist cause has remained relevant for post-Soviet Russian society, ensuring the continued engagement of Memorial activists. Yet for others who had joined Pamiat' primarily on ethical grounds or out of a passion for historical research and who cherished their independence, civil society activism and involvement with the political game were less attractive.

The evolution in terms of structure also shows a striking contrast between Pamiat' and Memorial. While Pamiat' was a purely volunteer-based project, conducted clandestinely, Memorial has sought, since its inception during Perestroika, to become registered officially and constitute an established, institutionalized movement. This process was coupled with a professionalization of its members: former editors of Pamiat' are now part of Memorial's staff and have turned into a life-long profession what was initially an amateur activity and an ad hoc response to a social need. This evolution from dissident activity to organized activism only became possible with the democratization of the state.

In terms of size, Memorial has grown into a large movement encompassing eighty local branches, extending into many countries of the post-Soviet space as 
well as Western Europe. Two major evolutions explain this successful enlargement. Firstly, Memorial became a multi-issue organization, dealing not just with historical research, or even the perpetuation of the memory of victims of political repression, but also more broadly with human-rights issues and the education of civil society. This was made possible by the liberalization of the regime, which broadened the range of issues that could be safely contested in the public arena and incorporated into the programs of institutionalized organizations; and it made the activities of Memorial more relevant to society than mere historical research, whose targeted audience was bound to remain limited. Secondly, the transparency characteristic of Glasnost and the post-Soviet era ensured increased publicity around the activities of Memorial, which allowed its membership to grow considerably. This was in contrast to the secrecy, conspiracy and anonymity that was required of Pamiat' members, contributors and readers, which kept their numbers low.

\section{Memorial: Achievements and Obstacles}

In a democratic Russia, it would seem that Memorial was well-placed to influence official politics of memorialization of Soviet-era political repression and public opinion on this issue. Yet twenty-five years after its foundation, Roginskii drew pessimistic conclusions regarding the activity of the organization. Although Russian society honors the memory of victims of political repression, it is reluctant to acknowledge, in a political culture that has traditionally regarded state authority as sacred, the responsibility of the Soviet state for the crimes committed. The defeat is both on a political and social level: on the one hand, the post-Soviet regime has failed to pass a legal act that would officially condemn the crimes of the Soviet era and has been little supportive of civil society initiatives in this domain; on the other hand, Russian society remains highly ambivalent about its past (Roginskii 2014). Numerous researchers make similar assessments (Sherlock 2007, 149-185; Adler 2005), deploring the decline of the liberal narrative in the Russian public space and the return of a heroic depiction of the Soviet past—and the "Great Patriotic War" in particular-in which Stalin occupies a prominent place. As Russian leaders sought to reconstruct a post-Soviet Russian identity, the appeal to a "useable past" implied the restoration of key elements of the Czarist and Soviet legacy; but such politics of selective memorialization also resonated with public nostalgia of the heroic legacy of the Soviet era in a period of national economic and political weakness. Therefore, the current climate of selective forgetfulness is a result of a complex mutual interaction between state and society. 
Although the tendency towards a rehabilitation of Stalin is reminiscent of the Brezhnev era, there are also clear differences. The memory of political repression, previously taboo, is no longer restricted solely to the private sphere. Instead, it has come to occupy a legitimate, and yet peripheral place in the public sphere, reflecting the difficulties that Russian society faces in assimilating a painful and divisive past, in which the roles of perpetrators and victims cannot be satisfactorily assigned. While civil society and local authorities have been consistently involved in perpetuating this memory, the Federal administration has remained conspicuously silent, abstaining from any legal or political evaluation (Roginskii 2011, 14-16). To a certain extent, the opposition can be boiled down to a contrast between, on the one hand, a mass public educated by new history textbooks tailored to promote "pride for their fatherland and its history" (Sherlock 2007, 172) and mass media relaying a world vision increasingly painted in black and white (Roginskii 2014), and, on the other hand, professional researchers publishing nuanced accounts of a complex and painful past, whose primary audience and support base is restricted to former victims of the Soviet regime and the liberal intelligentsia. According to Nanci Adler $(2005,1114)$, among the various versions of the past that coexist within Russian society, "the officially sanctioned version suppresses the Stalinist repression and commands the largest constituency," while "the iconoclastic version that emphasizes Stalinist repression commands a small and dwindling constituency within Russia. If the contested histories were to be decided by plebiscite, the minority version would be likely to disappear from Russia's history of itself."

It has been precisely Memorial's mission to prevent such a disappearance and to go beyond oversimplified visions of the past, acknowledging both its glorious and its more painful, shameful aspects. At the basis of the organization's involvement lay both the "aspiration to historical truth and the feeling of civil responsibility": the notion of guilt, following Roginskii's reflection, ought to be transformed not into fruitless repentance, but rather into an active position of civil responsibility meant to prevent future abuses and crimes (Roginskii 2014).

Although Memorial has failed to impose this vision on Russian society, it has nonetheless reached some of its objectives. It has fulfilled its initial goals of erecting a monument to these victims, on Lubianka square in Moscow, and of creating a research center with publicly accessible archives and a library. On a legal level, it has contributed to the passing of the 1991 "Law on the Rehabilitation of Victims of Political Repressions" and the declaration of October $30^{\text {th }}$ as the "Day of Memory of Victims of Political Repressions." It has also contributed to the relative opening of Soviet archives (Mezhdunarodnyi Memorial 2014a). Furthermore, Memorial's 
historians have published countless articles and monographs and created a number of databases on the history of Soviet repression and dissidence; and the organization has initiated and carried out numerous educational and commemorative projects in conformity with its mission.

Such developments, needless to say, would not have been possible in the totalitarian climate of the Brezhnev era. The fact that Memorial was able to carry out its actions relatively unimpeded testified to the silent acquiescence of the regime and to the possibility of a stable modus vivendi in relation to the authorities. Until recently, at least, one could say that Memorial had managed to occupy a certain niche allowing for its continued existence. This is a position that would not have been tenable in the Brezhnev era, when the Soviet regime considered any kind of independent initiative with utmost suspicion.

However, in recent years, Memorial has frequently been the object of administrative and political harassment, the most striking being its categorization as a "foreign agent," a label applied to Russian NGOs that received foreign funding while performing some kind of political activity, according to the November 21, 2012 law (Newsru.com 2012). Another attack was also launched against "Perm36 ," the only former Gulag camp turned into a museum, created by the Perm branch of Memorial. In January 2014, the regional authorities "nationalized" the museum, arguing that it would be financed by the state program for "the commemoration of the memory of victims of political repressions." However, the museum was simply closed to the public, and on June 25, 2014, the state program supposed to finance it was officially discarded. Although the museum might reopen, the ideological line will clearly be considerably altered by the new owners (Racheva and Art'emeva 2014).

Nevertheless, despite these attacks, Roginskii considered that the authorities "are forced to bear with us, to take note of our position and in some cases take us into account-and this is already a result, and not the least, of our work." The main question, he concluded, was not one of mutual hostility, but of the possibility of obtaining something from the state (Roginskii 2014). What remains to be seen is whether the state will attempt to take control of this field of memorialization so as to neutralize alternative discourses on the past, or whether it will allow nonstate organizations to pursue this social mission. In any case, it would seem that the conservation of a niche, albeit peripheral, for anti-Stalinism is necessary for Russia's image as a "democratic" state.

In conclusion, I would like to reflect on the relations between the notions of dissent, activism and repression, which have been central to this study. While activism does not necessarily trigger repression-indeed, in a democratic state, 
it should not-in the totalitarian context of the Brezhnev era, they usually went hand in hand. I have chosen to use the word "dissent" to refer to the case of Pamiat" because the participants in this project deliberately engaged in an activity which they considered socially significant, necessary, and yet knew could expose them to repression. By contrast, Memorial has sought from its inception to abide by the rules of the new political configuration, in a quasi-democratic context, to ensure that its activism would receive the broadest social resonance it could. In this sense, Memorial's activities qualify as activism as opposed to "dissent"-for the time being, at least.

Still, it should be noted that activism and dissent are not mutually exclusive notions. Indeed, the Soviet human-rights defense movement occupied as much a posture of dissent towards the regime as it was a form of activism targeted towards the Soviet people. By pursuing publicity both within and beyond Soviet borders, it actively strove to produce change. This, however, was not the orientation of Pamiat', which sought on the contrary to avoid any form of publicity on its activities in the Soviet Union and preferred clandestine action to provocation. The time was not yet ripe for safe activism, nor did it represent the preferred orientation of Pamiat's members. Memorial, in contrast, represents a project both inherited from Pamiat's fearless thirst for "historical truth" and from the human rights activism of the Soviet dissidence movement.

\section{References}

Adler, Nanci. 2005. "The Future of the Soviet Past Remains Unpredictable: The Resurrection of Stalinist Symbols Amidst the Exhumation of Mass Graves." Europe-Asia Studies 57 (8): 1093-1119.

Alekseeva, Liudmila. 1989. "RS 43/89 Interv'iu s chlenom rabochei kollegi 'Memoriala’ Arseniem Roginskim.” HU-OSA-300-85-13-249 Sam clip Bio Roginskii Arsenii. Radio Free Europe/Radio Liberty Archive, Open Society Archive, Budapest.

Alloi, Vladimir. 1998. "Zapiski autsaidera (Part 3)." Minuvshee (23): 159-203.

Beshenkovskii, Evgenii. 1981. "Rasprava nad uchenym.” Novoe Russkoe Slovo, August.

Bogoraz, Larisa. 2009. Sny pamiaty. Kharkov’: Prava liudyny.

Daniel', Aleksandr, and Larisa Bogoraz. 1993. "V poiskakh nesushchestvuiushchei nauki (Dissidentstvo kak istoricheskaia problema)." Problemy vostochonoi Evropy 37-38: 142-61.

Dediulin, Sergei. 1982. "Slavisty Frantsii - v zashchitu istorika Arseniia Roginskogo." Nasha Strana, May 9. 
Dediulin, Sergei. 2013. Interview with author, December.

Dobkin, Aleksandr, and Marina Sorokina, eds. 1995. In Memoriam. Istoricheskii sbornik pamiati F. F. Perchenka. Moscow: Saint Petersburg: Feniks-Atheneum.

Dolinin, V.E., Boris Ivanov, B.V. Ostanin, and Dmitrii Severiukhin, eds. 2003a. “Dediulin, Sergei Vladimirovich.” In Samizdat Leningrada 1950-e-1980-e: Literaturnaia Entsiklopediia, 170-71. Moscow: Novoe Literaturnoe Obozrenie.

Dolinin, V.E., Boris Ivanov, B.V. Ostanin, and Dmitrii Severiukhin, eds. 2003b. "Roginskii, Arsenii Borisovich." In Samizdat Leningrada 1950-e-1980-e: Literaturnaia Entsiklopediia, 316-18. Moscow: Novoe Literaturnoe Obozrenie.

Dolinin, V.E., Boris Ivanov, B.V. Ostanin, and Dmitrii Severiukhin, eds. 2003c. “Perchenok, Feliks Fedorovich.” In Samizdat Leningrada 1950-e -1980-e: Literaturnaia Entsiklopediia, 301-2. Moscow: Novoe Literaturnoe Obozrenie.

Dolinin, V.E., Boris Ivanov, B.V. Ostanin, and Dmitrii Severiukhin, eds. 2003d. “Dobkin, Aleksandr Iosifovich.” In Samizdat Leningrada 1950-e-1980-e: Literaturnaia Entsiklopediia, 173. Moscow: Novoe Literaturnoe Obozrenie.

Ferretti, Maria. 1993a. “Diventeremo tutti Mankurty?” In La memoria mutilata: La Russia ricorda, 77-111. Collana storica. Milano: Corbaccio.

Ferretti, Maria. 1993b. “Un Passato Che Non Passa. Memorial." In La memoria mutilata: La Russia ricorda, 342-90. Collana storica. Milano: Corbaccio.

Gasparov, Boris. 1981. "Poteriannoe pokolenie uchenykh.” Russkaia Mysl, October 10.

Grigor'ev, P. 1982. "Kak rozhdaiutsia 'utki', ili rasskaz o 'talantlivom issledovatele', 'izvestnom pisatele', i t.d.' Vechernii Leningrad, February 12.

hro.org. 2006. "Arsenii Borisovich Roginskii." Prava Cheloveka v Rossii. http./l www.hro.org/node/5665.

Ianovskii, Mikhail. 2010. "Maloizvestnaia stat'ia Larisy Bogoraz." Drugoi Gid (Prilozhenie: "Dekabr'skii sbor druzei”) (12): 146-51.

Igrunov, Viacheslav, ed. 2005. "Pamiat." Antologiia Samizdata. Nepodtsenzurnaia literatura $v$ SSSR. 1950-e-1980-e gody. Moscow: Mezhdunarodnyi Institut Gumanitarno-Politicheskikh Issledovanii.

Killingsworth, Matt. 2012. Civil Society in Communist Eastern Europe: Opposition and Dissent in Totalitarian Regimes. Colchester: ECPR Press.

Kopelew, Lew. 1981. “Lew Kopelew fordert: 'Helft Arsenij Roginskij!' Hinterlist der Gewalt." Die Welt (October 23).

M.H. 1982. "L'historien soviétique Arsenij Roginskij. Un historien en Union Soviétique." Cahiers Du monde russe et soviétique XXIII (I): 119-21. 
Markwick, Roger D. 2009. “Thaws and Freezes in Soviet Historiography." In The Dilemmas of De-Stalinization. Negotiating Cultural and Social Change in the Khrushchev Era., ed. Polly Jones, 173-92. New York: Routledge.

Medvedev, Roy. 1980. On Soviet Dissent. New York: Columbia University Press.

Mezhdunarodnyi Memorial. 2014a. "O nas." Mezhdunarodnyi Memorial. http:// www.memo.ru/s/62.html.

Mezhdunarodnyi Memorial. 2014b. "Memorial segodnia. Missiia i tseli." Mezhdunarodnyi Memorial. http://www.memo.ru/d/25.html.

Mezhdunarodnyi Memorial. 2014c. "Daniel' Aleksandr Iulievich." Mezhdunarodnyi Memorial. http://www.memo.ru/d/2653.html.

Newsru.com. 2012. "Putin podpisal zakon ob NKO-inostrannykh agentakh." Newsru.com, July 21. http://www.newsru.com/russia/21jul2012/nko.html.

Pamiat': Istoricheskii sbornik. 1978. Vol. 1. New York: Khronika Press.

Racheva, Elena, and Elena Art'emeva. 2014. "Revansh kuma." Novaia Gazeta, July 7.

RFE Research. 1981. "Sud nad Arseniem Roginskim. KL\#22." HU-OSA-300-8513-249 Sam clip Bio Roginskii Arsenii. Open Society Radio Free Europe/Radio Liberty Archive, Budapest.

Roginskii, Arsenii. 2011. "Pamiat' i svoboda, ili kak mnogo proshlogo sushchestvuiet v Rossii. Diskussiia o stalinizme v sovetskom i post-sovetskom rossiiskom obshchestve." Poslednie svideteli. http://www.1917-1991.org/m/veroffentlichungen/erinnerung-und-freiheit/?lang=ru.

Roginskii, Arsenii. 2014. "Chto takoe 'Memorial'? Chto delaet i chto uspela za 25 let znamenitaia obshchestvennaia organizatsiia? Ob"iasniaet Arsenii Roginskii." Colta.ru, January 31. http://www.colta.ru/articles/specials/1872.

Roginskij, Arsenij. 1982. "Ma Dernière Déclaration." Cahiers du monde russe et soviétique XXIII (I): 123-31.

Sabbatini, Marko. 2004. “K istorii sozdaniia 'Severnoi Pochty'. O Viktore Krivuline (Interv'iu s Sergeem Dediulinym.) Bibliograf, Izdanie assosiatsii "Russkii Institut $v$ Parizhe."

Sazhin, Valerii. 2014. Interview with author.

Sherlock, Thomas. 2007. Historical Narratives in the Soviet Union and Post-Soviet Russia: Destroying the Settled Past, Creating an Uncertain Future. New York: Palgrave Macmillan.

Sobranie Dokumentov Samizdata. 1981. "AC n 4524. Arsenii Roginskii, Istorik, $\mathrm{P} / \mathrm{z}$. 'Poslednee Slovo' na protsesse v narsude Oktiabr'skogo raiona g. Leningrada, 4.12.81."

“Solidarität mit Roginskij." 1981. Die Welt (November 25). 
“Spravka Nº 021634, SSSR Ministerstvo Vnutrennykh Del." 1985. Fond 155 A. Roginskii. Arkhiv Istorii Inakomysliia v SSSR, Obshchestvo "Memorial," Moscow.

Tolstoi, Ivan. 2012. "Mify i reputatsii. Uchitelia.” Interview of Marina Sorokina. Radio Svoboda. http://www.svoboda.org/content/transcript/24631326.html.

Tolstoi, Ivan, and Andrei Gavrilov. 2011. "Alfavit inakomysliia. Larisa Bogoraz." Radio Svoboda. http://www.svoboda.org/content/transcript/24342004.html.

Wishnevsky, Julia. 1981. "The Arrest of Arsenii Roginskii: A case of illegal entry into the 'spetskhran' (RL 320/81)." Radio Liberty Research. HU-OSA-300-85-13-249 Sam clip Bio Roginskii Arsenii. Open Society Radio Free Europe/Radio Liberty Archive, Budapest.

Zubarev, Dmitrii. 2013. Interview with author. 



\title{
Dissent as Race War: The Strange Case of Amiri Baraka
}

\begin{abstract}
This paper analyzes the rhetorical, textual, and performance strategies of black U.S. poet Amiri Baraka (1934-2014), categorizing him as an Africanist, (Inter)Nationalist, Marxist, and masculinist dissident, critiquing both majority/hegemonic discourses and most liberal-humanist leftwing positions producing counter-discourses in the USA over the last fifty years.
\end{abstract}

On January 9, 2014, the African-American dissident poet Amiri Baraka died in New York City, aged 79, from complications following an operation. He was, to the last, an unincorporated, angry voice on the poetical and political scene in the U.S. From his earliest days as a poet under the name of Leroi Jones, treading a road of independent magazine editing and publishing (Yugen and Floating Bear, among others [which he shared as a fellow traveler with the Beats]), through his time as a Black Arts Movement activist and his black nationalist incarnation as Amiri Baraka, Baraka always courted controversy by occupying dissident positions vis-à-vis the establishment as well as other liberal-humanist activists of the day. Baraka was something of the archetype of the ever-dissenting dissenter.

To frame Baraka's expressions of dissent, one might turn to definitions of dissent found in legal studies, where the concept has special resonance. ${ }^{1}$ Nan D. Hunter, while writing about the legal implications of practicing dissent as expressive identity, operates with a wider concept of dissent in relation to identity formation. Hunter $(2000,1-2)$ writes:

Social movements founded on identity politics generate claims based on shared identity characteristics in order to gain access to public and private domains. In our political life, identity politics is interwoven with dissent-is understood as dissent. Virtually all of

1 Broadly defined as an opinion crafted by a judge or several judges who are in a minority with regards to a legal decision leading to judgment in a case (usually one of principle and precedent formation). Dissent does not directly lead to precedent in such cases, but can inspire a change of law in subsequent cases if the original minority opinion later prevails to sway a majority of judges. Dissent in this definition thus carries a form of suspended or potential authority, which is a relevant connotation to carry over from the narrow legal definition of dissent into its broader meanings within cultural and social theory. 
the American civil rights movements since World War II have embodied the harmony between identity and dissent that exists in social practice, if not in law. By expressive identity, I mean those situations of particularly strong intersection, where an identity characteristic itself is understood to convey a message.

The movements of the mid-twentieth century seeking equal voting rights and nationwide and local political representation for African-Americans were this kind of social movement. For African-Americans in this period, and for several decades beyond, the "identity characteristic" in question "convey[ing] a message" would of course be black skin itself. One could additionally argue, along with Henri Tajfel (1970), that any civil rights movement or other group or movement "founded on identity politics" (using Hunter's core definition) thrives on an ingroup/outgroup dynamic, allowing its members to form strong internal bonds through emphasizing their essential differences from all outgroups, including, of course, hegemonic groups they might resist (obviously, for the African-American Civil Rights Movement, this was white, ruling class America with its virtual monopoly on political representation). ${ }^{2}$ When an ingroup identity is created and completely circumscribed by such an understanding of itself as dissent from the majority view and the hegemony supporting it, however, it follows that dissent, from an ingroup perspective, can become an orthodoxy excluding dissent from within such movements. Dissent from within automatically violates the group's core identity formulation. Strong formulations of dissent can thus paradoxically become new doctrines from which the group can barely deviate. Heterodoxy thus becomes difficult within groups that endure strong outgroup pressures to conform to hegemonic positions. As we shall see, Baraka is that rare voice constantly seeking space for heterodoxy: even within the ingroups with which he elected to travel intellectually.

Hunter identifies moments in the development of identity politics in the latter half of the twentieth century in America where the dynamics of the interplay between group identity and dissent against hegemony changed. She sees early cases of identity formation following World War I, such as might be found in activist groups pleading for the right to advocate pacifism, as Modernist, anti-authoritarian responses to the restrictions of free speech; such groups often thought it sufficient to plead for First Amendment rights to be upheld. A later second stage of identity politics, however, appears to offer a much wider opportunity for dissent, such that it might assume a more heterodox nature even within an ingroup identity enclosure. Hunter $(2000,2)$ writes the following about the late 1960s/early 1970s:

2 I will be using Taifel's unhyphenated spelling of the words "ingroup" and "outgroup." 
Equality movements that comprise the body of identity politics formed the second stage of this interaction between dissent and equality doctrine. What has come to be called a politics of presence, or recognition, sought space for previously excluded minorities, finding that invocations of universal rights like free speech too often translated into exclusionary blind spots and a failure to see that not everyone benefits equally from humanistic principles. Nonrecognition of subordinated identities within a discourse of freedom and democracy became understood as simply another form of oppression.

When free speech no longer suffices as a group's means to achieve the equal recognition, radicalization or overt politicization can occur. An example of this would be Martin Luther King, Jr.s attempt to take the African-American Civil Rights Movement into internationalist politics via protest against the Vietnam War (initiated with his 1967 speech "Beyond Vietnam: A Time to Break Silence"), as well as into anti-capitalist directions advocating the redistribution of wealth in America. ${ }^{3}$ King's assassination put a stop to both these efforts. As we shall see, similar moves of radicalization can be traced in Baraka's discursive practices in the late ' $60 \mathrm{~s}$ and early '70s. In such cases, one could argue-inspired by Hunter (though she does not take the issue quite this far) - dissent can become dislodged from identity expression as ingroup marker. Baraka was always willing to push the envelope of dissent within a particular ingroup. As a consequence, he often had to leave a particular peer group behind when his expressions became too dissonant with the ingroup identity.

I find Baraka interesting as a figure of continuing relevance to the study of oppositional discourses about race and identity in American history at-large, and within the discourse of left-wing dissent in the African-American community in particular. Baraka's work creates a specific but mobile, or heteroglossic, site of dissent that can be used to reimagine mainstream conceptions of the last five decades of the history of African-American opposition to white hegemony in the U.S. Baraka's identity positions were often so radical (and polemical) that they have been utterly excluded from mainstream debates about civil rights, masculinist gender positions, and African-American nationalism. One has to seek more narrow discourse communities engaged with internationalism in a Marxist setting, or conspiracy theories regarding American foreign policy, to find his work discussed. Even among literary scholars with interests in black poetry and drama, it is difficult to find detailed discussions of Baraka's most inflammatory works. The tendency is rather to group Baraka's works with the American avant-garde.

3 Scholars such as Carson (2005) concur with this assessment. 
This ghettoizes those works, as avant-garde works by definition cannot have the intention of reaching broad audiences or aiming for popular consciousness raising, whereas his $\mathrm{did}^{4}$

I would like to engage several moments in the development of Baraka as a dissident voice. First, I will look at his position on interpersonal violence in the face of racism in his early play Dutchman (1964). I will examine his apparent advocacy of rape as a means of subjugating women, homosexuals, and Jews in an essay from 1965 ("american sexual reference: black male" [the original title eschews capitalization]). I will also look at his proclaimed desire to create "poems that kill," exemplified with the poem, "Black Art," also from 1965. This section of the paper, in other words, deals with the early, radical practice of Baraka as a black masculinist advocate.

The second part of the article will discuss Baraka's journey from electing to be called Imamu Amear (or Ameer) Baraka (from 1967 to 1974) during his days of association with Kawaida philosophy and positions similar to the Nation of Islam (which again occasioned him to write texts directed against Jews) to a less Messianic stance as a Marxist sympathizer with Third World liberation movements under his final name, Amiri Baraka (taken in the mid-1970s) (Lee 2003). This section discusses his musical recordings in a style prefiguring rap, paying particular attention in the 1973 song "Who Will Survive America?". (The answer to that question being decidedly unrhetorical: "Very few negroes, no crackers at all!") This is taken from the album It's Nation Time, released by the Motown subsidiary label, Black Forum.

The last part of the paper will discuss the controversy following Baraka's poem questioning the official narrative behind the events known as 9/11. In the aftermath of the attack on the Twin Towers, Baraka wrote a poem entitled "Somebody Blew Up America?" (2002). Here, he blamed then President George Bush and Israeli intelligence services for not only having foreknowledge of the attacks, but also for instigating them as an excuse to attack "rogue states" in the Arab world. This controversy led to Baraka losing his position as Poet Laureate of New Jersey (the position was simply abolished), and also brought renewed accusations of anti-Semitism.

In conclusion, this article attempts to categorize Baraka as a heterodox dissident, learning from and influencing several positions of dissent against both majority/ hegemonic discourses and most liberal-humanist left-wing positions producing

4 Articles such as Smethurst (2003) and Won-gu Kim (2003) participate in this marginalization of Baraka as literary figure. 
counter-discourses in the U.S. over the last fifty years. It frames Baraka as an Africanist, (Inter)Nationalist, Marxist, and Masculinist advocate who often resorted to the trope of hyperbole to voice his viewpoints against a constitutionalist-racist and deaf establishment as well as a complacent neo-orthodox left-wing form of dissidence in American life.

\section{$* * *$}

The first part of Baraka's life that interests us here is the time immediately following his dishonorable discharge from military service for harboring Communist sympathies and concealing Soviet propaganda among his possessions in $1954 .{ }^{5}$ Baraka moved to Greenwich Village - a neighborhood favored by Bohemians attracted to the low rents and large affordable living spaces available in the area. The Village also housed innumerable coffee houses and music venues, again attracting a mixed crowd of jazz, poetry, and drug fans. Several of the key members of movements such as the Beat Generation, the New York School of Poets and Painters, and various fellow traveler artists (some associated with the experimental, interdisciplinary liberal arts institution, Black Mountain College) frequented the area in the mid- to late 1950s. Baraka's association with the Village is the first of a number of significant relocations in his formative years as a writer and activist (Watts 2001; Matlin 2013). These can be summed up as a slow dance around his birthplace of Newark, New Jersey, to which he eventually relocated for good in the '70s.

Leroi Jones, as he was known then, married a white, Jewish woman (the writer Hettie Jones, née Cohen) in 1958 and collaborated with her on several artistic projects typical of his younger hipster years. ${ }^{6}$ They co-founded a publishing house, Totem Press, and co-edited and published Yugen, a literary magazine that appeared from 1958-62. Jones also contributed to other little magazines of the period, including Kulchur and Floating Bear-the latter of which he co-edited with his lover Diane Di Prima, another white woman and a well-known Beat poet.?

5 Baraka discusses this period of his life in the chapter tellingly titled "Error Farce" in his The Autobiography of Leroi Jones (first published 1984).

6 Baraka's practice of changing his own name to reflect his political and aesthetic agendas is discussed exhaustively in Thompson (2002, 83-101).

7 Di Prima is a crucial innovator in her practice of joining confessional and political poetry together, often in hybrid forms combining journals, memoirs, and lyrical poetry. She was among the few female authors to emerge from the male dominated movements of the 1950s and early 1960s, such as the Beat Generation. Her collected papers are kept at the University of Delaware Library. 
As a result of these associations and collaborators, Jones began to be seen as a Bohemian, experimental writer in the same vein as Michael McClure, Allen Ginsberg, Jack Kerouac, Frank O'Hara, Charles Olson, Gary Snyder, Philip Whalen, Ed Dorn, and Diane Di Prima-all of whom were published or edited by Jones. It is clear from his own assessments of this epoch in his life that Jones was not overly concerned with issues of race, but rather issues of class and international solidarity-a claim further supported by the fact that in this period of his life Jones traveled abroad much more frequently than at any other time in his life. During this period, he visited Cuba (1960) and participated in various initiatives calling for equality and recognition between the First, Second, and Third worlds. His neo-Marxist political outlook made him particularly interested in collaborations with likeminded artists from developing countries and from behind the Iron Curtain, often drawing on networks that had already brought writers from these two locations (conventionally thought of as the enemies of the U.S.) together.

Around 1960, Jones' politics and aesthetics begin to shift. In 1961, again with di Prima, he founded the New York Poets' Theater group in the East Village. This indicated a shift towards a different genre and public, something he fully realized with the success of his own play Dutchman in 1964. The fact that theater is a more interactive medium than poetry may have appealed to Jones for strategic reasons connected with his desire for consciousness-raising. He wrote in his Autobiography that his entry into theater was prompted by his desire to make his poetry feel more active; he wanted his plays to move (Baraka 1997, 278; paraphrased in Als, 2014). In 1962 Jones' reading of Black American literature and literary history influenced him to join forces with other Black Nationalist writers such as Ishmael Reed in the Umbra Poets Workshop on the lower East side, prefiguring a more whole-hearted push in the same direction five years later with the Black Arts Movement. Jones published his first book of poems in 1961 (Preface to a Twenty Volume Suicide Note) and began a stream of social and aesthetic essays that later were collected in a number of volumes (for example, Home: Social Essays [1966]). Jones also composed several collections of writings on jazz and black music in general. ${ }^{8}$ In these writings, Jones began to separate himself from what he perceived as the mediocrity of black writers who let themselves be swallowed up by middle-class concerns and the integration or up-lift of the black race through white patronage. His successful play Dutchman is paradoxically both an example of such an

8 The original outlets for Baraka's jazz writings were varied, ranging from traditional mainstream jazz and general music magazines such as Jazz Review, Metronome, and Down Beat to Baraka's own little magazine Kulchur and race specific magazines such as Negro Review. 
unwelcome embrace by white intellectuals and moneyed patrons of the arts as well as an attempt, thematically, to challenge this practice and terrorize white audiences away from art such as this. This became Baraka's master strategy; one which he frequently resorted to in the later stages of his career.

In Dutchman, the simple action revolves around an encounter in the New York subway between a white woman, Lula, and a black Bohemian, yet intellectual figure (a version of Jones himself) whom the woman first flirts with, then starts mocking for his predictability and malleability (he is conveniently named Clay in the piece). ${ }^{9}$ Clay resists Lula's advances to a certain degree, but is fascinated with her power to predict his actions and guess aspects of his past that he would rather have remain unknown to people in general (specifically pertaining to his incestuous desire and scheming with regards to his own sister). When he can no longer stand Lula's provocative manner, he uses violence against her, de facto living up to the stereotype of the angry young male black predator Lula is trying to cast him as. He regrets his physicality instantly, suggesting that violence as the response to provocation is simply another form of entrapment of the black man-a deliberate part of the strategy for white subjugation of blacks, just as the apparent opportunities whites let blacks have in the field of the arts lure blacks into remaining primitive and unfocused in their goals of economic equality (tempting them with sex and artistic accolades to keep them uneducated and poor). While he is passionately espousing these views in an extended monologue, Lula, in a shocking turn-around, assassinates Clay just as he is beginning to clearly diagnose the plight of blacks like himself. In other words, when he comes close to grasping the truth, the white woman reveals her true predatory self as an agent of the white ruling class and literally kills him off. This play is thus a writing-through of Jones' own dilemma as an incorporated black middle-class artist. In hindsight, it is quite ironic that the play won an Obie Award for best American play of the year. This irony was not lost on Jones, who wasted little time in finding even more radical ways of expressing the twin issues of the play and his own artistic practice: black/ white sexual relations and the function of art in a divided society. As he comments in The Autobiography of Leroi Jones (Baraka 1997, 278):

What "fame" Dutchman brought me and raised up in me was this absolutely authentic and heartfelt desire to speak what should be spoken for all of us. I knew the bullshit of my own life, its twists and flip-outs, yet I felt, now, some heavy responsibility. If these bastards were going to raise me up for any reason, then they would pay for it! I would pay

9 See Piggford (1997) for a nuanced analysis of the plot and character dynamics of Dutchman. 
these motherfuckers back in kind, because even if I wasn't strong enough to act, I would become strong enough to SPEAK what had to be said, for all of us, for black people, yes, particularly for black people, because they were the root and origin of my conviction, but for anyone anywhere who wanted Justice!

In this passage, we can note Baraka's tendency to use organic, growth-related metaphors ("root," "raising up"). This indicates a lingering Black essentialism in Barak's thinking, even at the late date of 1979 when he had supposedly reverted to a Marxist, non-essentialist historical materialist way of thinking. ${ }^{10}$ Such essentialisms are worth noting when it comes to a comprehensive evaluation of Baraka's seemingly constant shifts in political position. He steadfastly clings to ideas of inherent black superiority throughout.

Turning to the collection of essays mentioned above, Home: Social Essays, we find some of Jones' most controversial formulations of the interracial sexual dynamics in the U.S. In the essay "American Sexual Reference: Black Male," Jones expresses his own sexual anxieties of hetero-normativity and racial stereotypes of black masculinity in extremely provocative terms. He accuses the majority of white males of being closeted homosexuals, jealous of black masculine prowess, and simultaneously white women of desiring to be raped by black men, as this is the only "legitimate" avenue white women of the time would have had to having sexual relations with blacks. Rape thus becomes a contested site where white women seek satisfaction through an encounter with black sexuality, and blacks are tempted to commit "the most heinous crime against white society... the rape, the taking forcibly of one of whitie's treasures" (Baraka 1966, 251). Of the available strategies a black person has to choose from, it seems that Jones is advocating the rape option as not the worst solution: "The average ofay thinks of the black man as potentially raping every white lady in sight. Which is true, in the sense that the black man should want to rob the white man of everything he has" (Baraka 1966, 255).

However, the rape here is clearly intended at least partly as a metaphor for property appropriation in general, i.e., as part of a black revolution against white economic domination. ${ }^{11}$ This is further clarified by the essay's contextualization of the black man's plight, which falls in two instantiations: the history of slavery for all African-Americans, and the practice of lynching, often accompanied by castration

10 According to Ben Lee (2003 372), Baraka "wrote his autobiography during forty-eight weekends in 1979, a good five years after he began his turn to Third World Marxism."

11 These essays thus prefigure by a couple years the better-known writings of Eldridge Cleaver (collected in his 1968 book, Soul on Ice) advocating much the same strategy of black on white rape and property acquisition by force. 
of "uppity" black males, long after the abolition of slavery. It is the anger and shame of this past of exploitation, manumission, and sexual humiliation and control that fuels Jones' vitriol against both white males (troped as "fags": "Most American white men are trained to be fags" [Baraka 1966, 255]) and white women (troped as property without independent agency, who sell their sexual favors in exchange for room and board in white nuclear families). This extreme form of dissent from mainstream views can be read as a distancing move away from black middle-class culture and from art-appropriate for a time when jazz was becoming incorporated in mainstream American literature and American poetry was beginning to openly embrace the figure of the homosexual male poet (figures like Ginsberg and Frank O'Hara). Jones moves away in extreme disgust (whether he did so partly to hide his own bisexuality, as some critics [Watts 2001, for instance] have suggested, falls outside the boundaries of my current inquiry) and advocates a deliberately exaggerated radical and violent, dissenting position.

The radicalization of Jones' sexual politics runs parallel to his radicalization concerning the role of poetry and arts in general during this period of the early to mid-1960s. The assassination of Malcolm X in 1965 further contributed to Jones' radicalization, and precipitated another physical move, this time to Harlem-a clear symbolic gesture of both separation from white Bohemia downtown, and unification with the African-American community uptown. This coincides with Jones' abandoning Hettie, his first wife, and their two children, followed in 1966 by his second marriage, this time to a black woman, Sylvia Robinson. In his poetry, the founding of the Black Arts Literary Movement (see Roney 2003 for a good account of Baraka's involvement with the movement) is accompanied by a poem/ manifesto, also titled "Black Art" (first collected in 1969 in the Black Magic volume, later selected for Transbluesency (Baraka, 1995)). One can hear this poem read aloud over free jazz accompaniment by Albert Ayler, Don Cherry, and others on a recording made in 1967 (Sonny Murray: Sonny's Time Now) and released on Jones' own label, Jihad Records. This recording may be the best way to approach the text since the enhancement of the words by the accompanying instruments and Jones' own use of his voice as an instrument helps us comprehend the political thrust of the manifesto (see Baraka 1967). In "Black Art," a multiplicity of voices are represented, performing, as it were, an internal debate in Jones' head, which becomes externalized and shared with the audience through the performance of the poem. The poem raises the question of the value of poetry. Must it be aesthetically pleasing? Must it be accepted critically, read by critics and other gatekeepers in a framework of literary and cultural history? Or must it ultimately only serve one function - that of empowering the black man? Jones leans towards the latter answer. 
The poem contains contentious lines such as "We want 'poems that kill.'/ Assassin poems, Poems that shoot/guns. Poems that wrestle cops into alleys/ and take their weapons leaving them dead." This apparent advocacy of violence in the struggle of black against white is complicated by descriptions of Uncle Tom blacks ("negroleaders," as Jones terms them twice in the text) performing fellatio on white sheriffs ("kneeling between the sheriff's thighs/negotiating coolly for his people" (Baraka 1995, 141-2), the poem sarcastically remarks) and otherwise compromising the purity of their black cultural legacy. Already in Dutchman, Jones represented such a black Uncle Tom collaborator with the white hegemony in the form of the black conductor tipping his hat to Lula after her murder of Clay. Jones' political agenda was now cast in terms of heritage and traditions: "Let Black People understand/that they are the lovers and the sons/of lovers and warriors and sons/of warriors Are poems \& poets \&/all the loveliness here in the world" he writes (142). This lyricism (as witnessed by the startling use of the word "loveliness") clashes strongly with the wish for violent revenge against cops, a "jewlady," and "beasts in green berets" expressed earlier. The poem opens with a long stanza, continues with a short five-line stanza and a punch line, quoted here in full: "We want a black poem. And a/Black World./Let the world be a Black Poem/And Let All Black People Speak This Poem/Silently/or LOUD" (142). The poem conflates black government with global revolution and suggests that poetry will serve as the trigger of said revolution. Jones (on the verge of becoming Baraka) occupies the doubly dissident position of being an internationalist (calling for global solidarity and revolution) and a Black essentialist in that there is no nuanced rationale for the predicted victory of the "Black people" other than their bond through race. As remarked earlier, this hidden essentialism can be traced throughout Jones/ Baraka's '70s writing up to and including the Autobiography of Leroi Jones. His masculinist agenda is still present, but here toned down in comparison with the previously examined texts (although white authority figures are also here lampooned for all being homosexuals, and women ["mulatto bitches" or "jewladies"] are presented throughout as victim figures).

$* * *$

It was around this time that Jones' effected his transition into an Africanized Muslim nationalist (1966-67). Baraka was involved in the race riots in Newark in 1967, where he advocated the unpopular view that not only was rioting in one's own neighborhood stupid from an economic perspective, but also that these particular riots were instigated and led by white "radicals" desiring to see blacks ruin their own property and lives. Baraka nearly spent time in jail for carrying a 
concealed weapon during the riots, and this brush with "white" law enforcement further radicalized him. Baraka sought out Maulana Karenga, who in the wake of the Watts riots in Los Angeles in the summer of 1965 had formulated similar concepts. Baraka was further pushed by Karenga's ideas of constructing not only an Africanist framework of holidays and observances for African-Americans (Karenga was instrumental in establishing Kwanzaa as a holiday), but also an Africanist political philosophy. In the mid-'70s, under the name of Kawaida, this philosophical system became established among Karenga's followers as an alternative to monotheistic guilt- and sin-based religions such as Christianity and Judaism. In place of such concepts, Kawaida sought to establish a rootedness in African Animist traditions without descending into what Karenga $(1977,14)$ termed "spookism"-superstition and repressive practices. An important part of this revival of African tradition was to abandon Christian naming traditions and revert to names and titles of, for instance, Swahili or Yaruba origin. Maulana Karenga's own name translates as "Master Teacher, Keeper of the Tradition," a far cry better than his first name, Ron Everett. Under Karenga's mentorship, Jones now became Imamu Ameer Baraka (the individual Yaruba parts of which correspond to "Spiritual Leader," "Prince," and "Blessing"). Baraka soon dropped the Imam part of his new name, but kept the latter two parts (with minor spelling changes) for the rest of his life, and his wife similarly transformed herself into Amina Baraka.

Textual traces of Karenga's influence on Baraka include a slew of anti-Jewish writings about which Baraka later repented. At the time, however, perhaps these merely seemed extensions of Jones' frequent, casually-dropped anti-Semitic slurs (for which there in fact was a long tradition in black writing, especially among Harlem Renaissance authors such as Langston Hughes [Hughes was as fond of the trope of the Jewish money lender and extortionist landlord as any-see for instance his 1927 poetry volume Fine Clothes to the Jew]). But while Baraka's actual Islamic faith remains curiously unexplored and tends not to push itself forward in his writings, his conversion to Islam may also have contributed to anti-Jewish sentiments coming to the fore. As Baraka again shifted back to a more Marxist and internationalist stance, he actively sought to rephrase his anti-Jewish sentiments as politically motivated anti-Zionist positions and indeed as part of a general anti-imperialist ideology (see Melnick 2001, 1028). This move away from a narrow Nationalism, particular to African-Americans, also meant that Baraka left behind the idea of Black (American) Arts as particularly aesthetically valuable. The rift between Baraka and The Black Arts Movement was quite acrimonious, as Baraka termed some of his movement fellows "capitulationists" (in Martin 1995), indicating that they once again had let 
their art become co-opted by white consumers and liberal activists. By 1974 Baraka openly declared himself as an internationalist Marxist, thus in a sense returning to his stance of twenty years earlier, which had earned him a dishonorable discharge from military service.

In the early 1970s, Baraka also returned to the idea of music and performance as a way to retell history and to raise consciousness. Motown had, under pressure from Black Power groups, decided to reinvest some of their profits from crossover hits over the decade of the 1960s in a venture intended specifically for a black audience, and a spoken-word label titled Black Forum was launched to market and sell motivational speeches and testimonials of, for instance, black Vietnam veterans. ${ }^{12}$ The label also issued a few musical albums, including a groundbreaking recording with Baraka (who had sung with doo-wop groups back in the 50s). The most interesting track on It's Nation Time is the early rap-funk-style number, "Who Will Survive America?". The album advocates Black Nationalism, and several tracks have titles in Swahili. The concept behind the record is to narrate, "How Africans got to be Negroes," as another title goes. The lyrics are in a sense an updated version of "Black Art." Baraka is less concerned with the "Crackers," whom he is convinced will not survive at all, and more with the backsliding or capitulationist blacks, who also face decimation in the coming race war. He uses stereotypes of blacks to categorize these endangered groups: drug addicts ("4-bag Jones"), prostitutes and other women who don't work real jobs, fat people who live to eat, as well as Baptists and members of other Christian denominations. Who will survive? Baraka's answer is depressingly simplistic: "But the black man will survive America/His survival will mean the death of America." We are to imagine a rebirth of a Black nation on the ruins of what was formerly America, one cleansed of religion, vices, corruption and women.

The misogyny of the lyrics is quite remarkable (for a general discussion of misogyny in Black Nationalist literature, see Leonard 2013). Two types of black women are singled out for negative treatment. First, the type of women that we also encountered in the "Black Art" poem, but here even more overtly described as prostitutes: "Will you survive, woman?/Or will your nylon wig/Catch afire at midnight and light up Stirling Street/And your assprints on the pavement." This is positively biblical in its evocation of death by fire next time the apocalypse comes rolling around; and simultaneously reifying in the extreme, reducing the women

12 For the best account of the relationship between Black Power movements and popular music, including a chapter on Baraka's Black Forum release, see Thomas (2012) and its companion $\mathrm{CD}$. 
in question to accessories ("nylon wig") and traces of shame ("assprints"). Second, Baraka turns directly to women of faith: "The stiffbacked chalklady baptist, in blue lace/If she shrinks from blackness in front of the church/Following the wedding of the yellow robots/Will not survive./She is old anyway, and they're moving/Her church in the wind." Here it is worth noting the generational aspect of Baraka's indictment of the church lady as being "old" and therefore irrelevant to the postapocalyptic world of surviving America. The institution of the church is seen as a shallow refuge for race traitors who "shrink from blackness." In sum, this song's lyrics are both the apex and swan song of Baraka's Black Nationalism. They are also clearly one of his most misogynist texts.

$* * *$

In the chronology of Baraka's career, this article elects to now fast-forward nearly thirty years. Baraka's middle years were less riddled with controversy and political position shifting than the first two decades of his intellectual and political development, a fact that coincides with his slow acceptance in the academic world. Baraka spent the 1980s and early 90s holding various university positions, eventually becoming a professor emeritus of African Studies at State University of New York, Stony Brook. He also garnered literary accolades, including winning two American Book Awards for volumes he edited or co-edited (he won a final one in 2010 for a book of musical history). This tranquil middle period of his public career can therefore be seen as the closest Baraka came to being incorporated into the mainstream of American intellectual and artistic life.

In 2002, however, Baraka again became the focus of national controversy when he used the newly instituted office of Poet Laureate of New Jersey to present a poem he had written in the immediate aftermath of the events on September 11, 2001. In the poem "Somebody Blew Up America," Baraka lets a number of voices (all vernacular) ask literally dozens of rhetorical questions, all pertaining to heinous acts of violence, genocide, war, and crime; each line giving voice to a group who has suffered at the hands of the group behind the "who" of their question. The base of the poem is the repeated questioning phrase: Who did something (bad) to somebody? Often the most obvious answer is: "The USA." On other occasions a better answer might be, "Imperialism," and on yet others, "The capitalists." A sample of the poem runs like this:

Who killed the most niggers

Who killed the most Jews

Who killed the most Italians

Who killed the most Irish 
Who killed the most Africans

Who killed the most Japanese

Who killed the most Latinos

Here one would be able to use all three of the answers suggested directly above. In another sequence, the answer points more unambiguously to the U.S., and specifically to its ruling class and the politicians and straw men "owned" (see the lines indicating hidden owners behind apparent owners: "Who own what ain't even known to be owned/Who own the owners that ain't the real owners") by its members:

Who make the credit cards

Who get the biggest tax cut

Who walked out of the Conference

Against Racism

Who killed Malcolm, Kennedy \& his Brother

Who killed Dr King, Who would want such a thing?

Are they linked to the murder of Lincoln?

These lines indicate Baraka's tendency to conflate events across considerable historical distances; a point he deliberately emphasizes to indicate that depressingly little has changed in the corrupt power structure of America and its racially-biased practices from the emancipation of the slaves under Lincoln, via the civil rights struggle in the 1960s, to the new millennium. In a manner familiar from any number of conspiracy theories, Baraka also connects events that in traditional history writing are seen as separate; for instance, the banking system offering credit to relatively poor blacks to entice them to become addicted to consumer goods, thereby entrapping them in debts they can never hope to repay (a modern day form of slavery).

The main controversy attached to the poem had to do with the following lines:

Who knew the World Trade Center was gonna get bombed

Who told 4000 Israeli workers at the Twin Towers

To stay home that day

Why did Sharon stay away?

Other lines suggest that Israelis photographed the event from the Jersey shore and celebrated loudly as the planes hit. These questions hit a bit too close to home for most Americans in the traumatic aftermath of $9 / 11$, and the outcry against Baraka for making this suggestion was considerable, even as all of his other suggestions of American involvement in genocide and far more wide-reaching global atrocities caused not a single eyebrow to be raised. The poem is in fact completely of a piece with Baraka's latter-day international Marxist credo that capitalism, 
rather than national interests, fuels international politics. In the case of 9/11, it is suggested that the alliance with the Saudis to maintain high prices for Saudi oil mandated a war against alternative producers of fossil fuels (such as Iraq) and that the American government was actively involved in the carrying out and subsequent cover-up of the attacks. (In a curious case of strange bedfellows, JewishAmerican graphic novelist Art Spiegelman [2004] made similar suggestions and sparked a similarly hysterical reaction with his In the Shadow of No Towers.) In the heat of the hysteria of the reception of the poem, it seems nobody had the time or inclination to read the poem's ending where Baraka begins to distance himself from some of the claims implicit in the asking of the many questions: "We hear the questions rise/In terrible flame like the whistle of a crazy dog/Like the acid vomit of the fire of Hell." This is the first and only instance of a first person speaker in the poem. We can safely assume that Baraka up to this point has been ventriloquizing on behalf of other groups, posing the burning questions of the criminals the poem indicts. Nowhere does he use the first person singular "I," and only in this one line does he use the first person plural, assuming spokesmanship for a whole group, the collective witnesses of the horror of this the latest crime against America (remember the entity that is named in the poem's title is the nation of America as a whole).

The ending of the poem features intertextual similarities with songs such as the Rolling Stones' "Sympathy for the Devil" (more overtly narrated by the horned one himself); and the whole basic structure of the poem echoes Allen Ginsberg's by now consecrated all-American queer poem "Howl," in which the first part features numerous lines starting with the word "who" (albeit used as a relative rather than an interrogative pronoun). One might ask, rhetorically, why none of the political commentators who thought themselves capable of literary criticism in the case of Baraka consulted anyone with the most basic ability to perform textual analysis.

Who is the ruler of Hell?

Who is the most powerful?

Who you know ever

Seen God?

But everybody seen

The Devil (Baraka 2003, no pagination)

In these questions, posed near the very end of "Somebody Blew Up America," Baraka comes closer than ever to a religiously founded dualism that actually suggests that he had mellowed from his earlier rather monistic simplicities in his 
poetry of the 1960s. The poem is an astute diagnosis, as well as a heteroglossic raw slice of the discourse of post-traumatic stress that dominated the months following 9/11 in both the public and private spheres of the United States.

$$
* * *
$$

I think it appropriate to advance the following hypothesis concerning Baraka's textual and political practices: Baraka had, from the earliest instances of his published work, favored tropes of reversal and hyperbole. Had he only desired to reverse hierarchies such as black and white, or man and woman, he would have been a relatively harmless, easily incorporated writer who might have won instant favor with liberal intellectuals of both genders and races. Having instead chosen not to invert hierarchies like many left-wing populists of his generation (for instance advocates of affirmative action programs), but rather to blast them with exaggerated force, Baraka alienated many of his readers. I do not wish to exonerate him from accusations of reverse racism and misogyny. Rather, I wish to suggest that we include in our reading of his works a cultural context as well as a psychological one, and that when doing so the necessity of the anger expressed against those who were not with his program for the new world order becomes easier to understand. One must not underestimate the importance, either, of black history globally or in the U.S. particularly. A people brought entirely against their will to another continent, held in slavery and near-universal contempt, exposed to genocide and mass rape, exploited as cheap labor, victimized in the prisonindustrial complex-such a people in all likelihood needs voices that express pride in its origins, and unfortunately also needs voices that point to its victims. Our identity projects proceed according to how we discourse about who we are and who we are not. We have few other options.

In Baraka's case, his spokesmanship for shifting groups and identity positions are usually destabilized from within by his preference for dissent over positive identity building. As a result, Baraka naturally estranged several of the groups one would immediately have assumed would claim a poet such as him as a role model. Baraka remained, as his old friend and foe Ishmael Reed pointed out in his memorial words for Baraka, what the media like to call a "polarizing" figure. To Reed, he was much more and much less. He sums it up in these two quotes: "What he said offended the members of what he would call "the ruling class." He used his talent to write scathing indictments of racism and the capitalist system"-and: "Baraka's artistic peers thought enough of his talent to admit him to the exclusive American Academy of Arts and Letters. Maybe they recognized that Amiri Baraka was the kind of writer who comes along once in a generation 
or so. I once said that he did for the English syntax what Monk did with the chord. He was an original" (Reed 2014). In supplement to this political-aesthetic assessment, one could suggest that Baraka took great care to remain a dissident's dissident. By this, I mean Baraka followed no one for very long, he trusted his intellect to moderate his hyperbolic tendencies over time, and he was an indispensable voice even in the so-called post-racial latter days of American history where he tirelessly pointed out that the fact that the current President is black is not synonymous with institutional racism having ended. The race war that Baraka feared and desired is still a potential outcome for America (and recent events in Ferguson, Missouri might be indicative of violent confrontations being easily triggered by factors such as excessive force used in policing). One might then fear a renewed relevance to Baraka's question of "who will then survive?" His answer was and remains: "Very few Americans..."

\section{References}

Als, Hilton. 2014. "Amiri Baraka’s First Family.” The New Yorker (January 11). http://www.newyorker.com/books/page-turner/amiri-barakas-first-family

Baraka, Amiri. 2003. Somebody Blew Up America \& Other Poems. New York: House of Nehesi Publishers.

Baraka, Amiri. 1997. The Autobiography of Leroi Jones. Chicago: Lawrence Hill Books. [Revised ed. of 1984 publication].

Baraka, Amiri. 1995. Transbluesency: The Selected Poems of Amiri Baraka/Leroi Jones (1961-1995). New York: Marsilio Publishers.

Baraka, Amiri. 1973. It's Nation Time. Detroit: Black Forum/Motown. [LP record]. Baraka, Amiri. 1968. Black Music. New York: Akashic Books.

Baraka, Amiri. 1967. "Black Art." https//www youtube com/watch?v=Dh2PtlEH_w [YouTube video; Accessed January 22, 2014].

Baraka, Amiri. 1966. Home: Social Essays. New York: Akashic Books.

Baraka, Amiri. 1964. Dutchman and The Slave: Two Plays. New York: Morrow.

Baraka, Amiri. 1961. Preface to a Twenty Volume Suicide Note. New York: Totem Press/Corinth Books.

Carson, Clayborne. 2005. "King's Path to Antiwar Dissent." Magazine of History 19 (1): 27-28.

Cleaver, Eldridge. 1967. Soul on Ice. New York: McGraw Hill.

Ginsberg, Allen. 1957. Howl and Other Poems. San Francisco: City Lights Books. Hunter, Nan D. 2000. "Expressive Identity: Recuperating Dissent for Equality." Harvard Civil Rights-Civil Liberties Law Review 35: 1-55. 
Karenga, Maulana. 1977. Kwanzaa: Origin, Concepts, Practice. San Diego: Kawaida Publishing.

Lee, Ben. 2003. "LeRoi Jones/Amiri Baraka and the Limits of Open Form." African American Review 37 (2/3): 371-387.

Leonard, Keith D. 2013. "LOVE IN THE BLACK ARTS MOVEMENT: The Other American Exceptionalism.” Callaloo 36 (3): 618-624, 836-837.

Martin, Reginald. 1995. The Oxford Companion to Women's Writing in the United States. New York: Oxford University Press.

Matlin, Daniel. 2013. On the Corner: African American Intellectuals and the Urban Crisis. Cambridge, MA: Harvard University Press.

Melnick, Jeff. 2001. "Imagining Each Other: Blacks and Jews in Contemporary American Literature." Modern Fiction Studies 47 (4): 1027-1029.

Piggford, George. 1997. "Looking into Black Skulls: Amiri Baraka's Dutchman and the Psychology of Race." Modern Drama 40 (1): 74-85.

Reed, Ishmael. 2014. "Ishmael Reed on the Life and Death of Amiri Baraka" The Wall Street Journal, January 12, 2014. Online version http://blogs.wsi.com/ speakeasy/2014/01/12/ishmael-reed-on-the-life-and-death-of-amiri-baraka/ [Accessed September 16, 2014].

Roney, Patrick. 2003. “The Paradox of Experience: Black Art and Black Idiom in the Work of Amiri Baraka." African American Review 37 (2/3): 407-427.

Smethurst, James. 2003. "'Pat your foot and turn the corner': Amiri Baraka, the Black Arts Movement, and the Poetics of a Popular Avant-Garde." African American Review 37 (2/3): 261-270.

Spiegelman, Art. 2004. In The Shadow of No Towers. New York: Viking Adult.

Tajfel, Henri. 1970. “Experiments in Intergroup Discrimination.” Scientific American 223: 96-102.

Thomas, Pat. 2012. Listen Whitey!-The Sounds of Black Power 1965-1975. Seattle: Fantagraphics.

Thompson, Deborah. 2002. "Keeping Up with the Joneses: The Naming of Racial Identities in the Autobiographical Writings of LeRoi Jones/Amiri Baraka, Hettie Jones, and Lisa Jones." College Literature29 (1): 83-101.

Various Artists. 2012. Listen, Whitey! The Sounds of Black Power 1967-1974. Seattle: Light in the Attic Records [Compact Disc].

Watts, Jerry Gafio. 2001. Amiri Baraka: The Politics and Art of a Black Intellectual. New York: New York University Press.

Won-gu Kim, Daniel. 2003. "In the Tradition: Amiri Baraka, Black Liberation, and Avant-Garde Praxis in the U.S." African American Review 37 (2/3): 345-363. 


\title{
Hasmet M. Uluorta ${ }^{1}$ \\ The Tea Party: An Ethical All-American Performance
}

\begin{abstract}
Sustained dissent within the United States has come in the form of the Tea Party Movement. Emerging in 2009, this movement demands more neoliberalism, not less. This chapter seeks to understand the persistence of the movement, and more broadly the lack of transformation within the American political economy, by focusing on the constituting role played by fantasy and ethics in politics. Fantasy and ethics speaks directly to an identification, which I refer to as the ethical All-American, that Tea Party members aspire to be. This identification, I argue, gives shape to the politics of dissent.
\end{abstract}

Ongoing structural transformations within the American disciplinary neoliberal model of development, and the resultant hyper-contradictions, have not resulted in a widespread sustained demand for, nor radical transformation of, the existing model as might have been expected. Neoliberalism, it appears, has been far more robust, and consent remains forthcoming. Ironically sustained dissent, whether through the legislative process or protests, has come in the form of the Tea Party movement (TPM) that continues to shape political discourse and legislative processes. Emerging in 2009, the TPM demands more neoliberalism, not less. Demanding a more ideologically genuine form of nationalist neoliberalism, the TPM does not adhere to the refrain common to the World Social Forum and, more broadly, the alterglobalization movement, "another world is possible" (Hammond, 2003). Rather, they instead express what they believe should be the "limits of the possible" (Braudel, 1979), with limited government intervention and limiting individual choice. How then should this form of dissent be theorized?

I argue that a political economy that combines fantasy and ethics provides the most effective way to understand the persistence of the TPM and the lack of transformation within the American model of development. Still, fantasy and ethics, as constitutive elements of the framing of political economy, remain largely undertheorized. Understanding fantasy and ethics as triggers for political transformation, or lack thereof, highlights the significance of the dissent emanating

1 This research was supported by a Trent University SSHRC Travel Grant. The author wishes to thank the organizers of the Dissent! Conference for the invitation to present on this topic and particularly Ben Dorfman, along with an anonymous reviewer, for the constructive comments that greatly improved this chapter. 
from the TPM. It speaks directly to an identification of what Tea Party activists aspire to be, what they believe every American should become, and how politics and policy should be formulated. Employing a Lacanian and neo-Gramscian framework, I refer to this identification as the ethical All-American.

Identifications are not internal to the individual and instead speak to how an individual finds something to identify with. The term identification introduces an irreducible gap between individuals and the identity they seek to claim as their own. That outside identity is comprised of the dominant ideology; that is, it is structured in this case through nationalist-patriotic, religious-moral, and free market capitalist discourses. Jacques Lacan (2006, 75-81) refers to this structure as the mirror stage. This structure is productive of the politics of dissent (and consent), as the gap, or lack, induces a desire on the part of the individual to overcome it. By asking what is it that the "Other" (that is, the dominant ideology) desires of me (chè vuoi?), the individual attempts to bridge the gap through fantasy: of an image of a complete and ethically ideal individual (Lacan 2006, 690). Dissent (and consent) is shaped by this desire to unify with the identification.

The paper proceeds in four sections. In the first section I provide a background to the TPM. In the second, I establish the manner in which consent, dissent, and ethics are inextricably intertwined in both neo-Gramscian political economy and Lacanian psychoanalysis. This is followed by a discussion of the three discourses that structure the desire of Tea Party activists and animate the movement. The fourth section provides an interpretation of how the three discourses elicit consent and dissent through the structuring of the ideal-type image of the ethical All-American. The paper ends with a brief discussion of the shape the fantasy has taken and how it is an integral means for maintaining neoliberalism within the United States for the foreseeable future.

\section{Background}

Emerging in 2009, the Tea Party Movement (TPM) consists of a diverse constellation of groups and worldviews including libertarians, social conservatives, the Evangelical religious-right, nationalists, populists, and wealthy financiers such as Freedom Works and Americans for Prosperity. While a number of organizations including the Tea Party Patriots, Tea Party Express, Tea Party, and Tea Party Nation have garnered national and international attention, there are a range of organizations, with different scales, forming and re-forming. With no single overarching organization representing the Tea Party, it is better described as a movement. The TPM, however, coalesces around the idea that dissent is not only patriotic but also a necessary part in restoring the United States to what the TPM views as its core 
values of fiscal responsibility, constitutionally limited government, and personal responsibility within free market capitalism (Tea Party Patriots, 2013).

Viral videos and messages sent in direct response to the 2008-2009 financial and housing crises formed the immediate triggers for the emergence of the TPM (Brody, 2012). Arguably the most influential of these came in what is often referred to as "Santelli's Rant," in February of 2009. Santelli, a reporter on the CNBC business program called Squawk Box, accused the Obama administration of promoting "bad behavior" with the announcement of the expansion of bailouts that President Bush had initiated. Santelli (2009) shouted,

This is America! How many of you people want to pay for your neighbour's mortgage that has an extra bathroom and can't pay their bills? Raise their hand. President Obama, are you listening? We're thinking of having a Chicago Tea Party in July. All you capitalists that want to show up to Lake Michigan, I'm gonna start organizing.

Conservative radio host Rush Limbaugh transmitted the rant to a much larger national audience adding, "this is the pulse of the revolution, starting today! When the pulse of the revolution starts, it just takes an action like this to inspire confidence in others who want to show up" (in Meckler and Martin 2012, 8). With Facebook pages, websites, the Twitter hashtag \#TCOT, and growing media coverage, the TPM quickly gained momentum as the primary political force espousing dissent within the United States. These activities culminated in a national day of protests on April 15,2009. Protests were coordinated in major cities with approximately 500,000 people participating (O'Hara and Malkin, 2010, 19).

The TPM's dissent would translate into electoral successes as Tea Party candidates such as Marco Rubio and Allan West in Florida, Rand Paul in Kentucky, and Scott Brown in Massachusetts were elected to the Congress in 2010. The electoral successes, along with the momentum generated by the TPM, led to the creation of the Tea Party Caucus within the US congress. While these attest to the vibrancy of the TPM, there have also been failures. Candidates affiliated with the TPM were unable to take control of the Senate in 2012. TPM presidential candidates, such as Representative Michelle Bachmann and Texas Governor Rick Perry, failed to win the Republican Party nomination in 2011. In 2013, the TPM failed in their attempts to stop the raising of the debt ceiling and they failed to defund the Affordable Care Act. These failures have intensified internal divisions within the Republican Party and have spawned a movement to minimize the impact of the TPM.

Attempts to marginalize the TPM's dissent are not limited to the Republican Party. With strong financial support from groups such as Freedom Works and Americans for Prosperity, the favorable coverage by news organizations such as Fox News have led some to describe the TPM as an AstroTurf rather than arassroots 
movement (Krugman 2009, Arceneaux and Nicholson 2012). Astroturf is a form of synthetic carpeting that mimics real grass. Social movements that arise from hidden interests and not from community based politics are seen as artificial. Power does not stem from the group themselves but instead is oftentimes hidden or more elusive. Describing the TPM as astroturf has meant that the movement lacks authenticity and therefore is not a reflection of widespread political dissent. In short it can be easily dismissed. While the TPM has been the beneficiary of support from powerful agents such as FreedomWorks, it is an overstatement to categorize it in these terms. Geoffrey Kabaservice (2013) notes that what is surprising is how media outlets and conservative political organizations have tended to view TPM dissent as an unprecedented phenomenon. Isaac Martin (2013) reinforces this research arguing that rich peoples movements masquerading as people's movements have a long history within the United States. The TPM is not an exception to this but rather a continuation of the tradition.

What is distinct is the timing of the TPM's emergence in an era intensifying globalization and American crises. The hyper-contradictions, such as financial and environmental crises, geopolitical instability, and intensifying income inequality that are present make the TPM itself a contradictory manifestation. TPM's positioning cannot be reduced to a single domain such as liberal economics nor to a neatly packaged frame of thought such as conservatism. This ambiguity suggests that their positioning is in part a consequence of pre-conscious knowledge, which is now sedimented knowledge emanating through the leadership of three dominant discourses in the U.S.: the nationalist-patriotic, the religious-moral, and the free market capitalist.

These conform to the TPM's three principles of fiscal responsibility as a patriotic duty, constitutionally limited government as a moral obligation, and free market capitalism as the only legitimate form of economic organization. They have not only invested their own identity in these discourses but firmly believe that their "...founding principles are the same as America's. These beliefs are in America's DNA; they are each American's birthright" (Meckler and Martin 2012, 23). Contained within this quotation is the basis for TPM's consent as well as dissent. I would now like to turn to this issue.

\section{Consent, Dissent, and Ethics: Towards a Different Political Economy}

Neo-Gramscian scholars have theorized consent, dissent, and ethics extensively through the Gramscian analytic of hegemony. Hegemony forms the basis for legitimizing a particular mode of development. In the case of the contemporary United 
States, that model is the disciplinary neoliberal model (Gill 1995). Hegemony expands politics from the realm of seizing state power to the wider context of ethics, leadership, and consent within the economy, the state, and civil society. Furthermore, it includes a temporal dimension due to Gramsci's (1999) consideration of the role played by pre-existing institutions (e.g., family, schools) and episteme (e.g., Church, knowledge, law, and philosophy). In other words, history is conceptualized as a political process rather than the unfolding of transcendental laws. Likewise, Gramsci conceives of human nature not as fixed, but rather as amenable to change through political processes.

This complex ensemble has compelled neo-Gramscians to insist that neither consent nor dissent be taken for granted. Gramsci's $(1999,13)$ description of the "organic intellectual," for example, makes it clear that leadership and the establishment of a mode of development is made possible only when it is seen as both drawing on and guiding the ethical commitments and worldviews of those being led.

Within this articulation, consent is both constituted and re-constituted by the enveloping acceptance of the individual and subsequent sedimentation of an assortment of values, worldviews, and ethics that are supportive of established power relations described as an historic bloc. For Gramsci, ethics are central to this formation and cannot be parsed out from the political. Ethics form the basis for consent and by extension dissent. Conceptualized as ethico-political, the role of organic intellectuals is to act as a unifying force through ethical and intellectual leadership. This counters the disunity of interests that is generated at the level of the economy, which requires domination to become a unifying force. Brought together this dialectic produces the possibility of hegemony.

The neo-Gramscian approach has built on the notion of hegemony, extending it to a theorization of disciplinary neoliberal globalization. In particular, and for the purposes of this chapter, the work of Stephen Gill $(1995 ; 2008)$ provides both clarification and alteration to Gramsci's original text. Gill adapts Gramsci's text by positing that the formation of an historical bloc is not automatically synonymous with hegemony. Instead, the disciplinary neoliberal model is more readily identifiable with "supremacy" (Gill 2008, 125).

Disciplinary neoliberalism is a particular model of development that requires the political subordination of the state, society, and labor to the utopian vision of a free capitalist market (Gill 1995). In terms of the state, this has meant cutting of public expenditures, deregulation, and focusing on competitiveness. Economically, it has meant the re-introduction of neo-classical economics that prioritizes the capitalist market economy. Gill posits, however, that this model is not hegemonic but supremacist. Supremacy is defined as "...rule by a non-hegemonic bloc of 
forces that exercises dominance for a period over apparently fragmented populations until a coherent form of opposition emerges" (Gill 2008, 125). Supremacy has emerged through exposing the weak (e.g., precariously employed) to capitalist market forces while maintaining social protections for the strong (e.g., highly skilled workers in the technology sector and unionized manufacturing workers).

This asymmetrical inclusion, for Gill, is productive of both ongoing consent and dissent. The unequal distribution of life chances produces a disciplinary class who consent to the existing order and a class left to dissent from the order in which they are only precariously integrated anyway. Yet, as I argue here (expanding on Gill's work), it also produces dissent with those who seek greater adherence to the dominant ideology such as the TPM. As Vanessa Williamson, Theda Skocpol, and John Coggin $(2011,32)$ observe,

Tea Party activists view themselves in relation to other groups in society...Tea Party activists in Massachusetts, as well as nationally, define themselves as workers in opposition to categories of nonworkers they perceive as undeserving of government assistance.

In this way, the neo-Gramscian framework challenges the binary of consent and dissent, revealing that supremacy can be productive of a messy configuration.

This analysis is significant in that it lays bare the way in which the current disciplinary neoliberal model has failed to become a hegemonic formation. It remains highly susceptible to dissent, which can be authoritarian just as much as it can be democratic. In other words, the demand could be to 'intensify neoliberalism,' or it could be to 'change now.' The two are not mutually exclusive.

The neo-Gramscian approach, however, would be well served to re-examine Gramsci's distinction between common sense and good sense. Gramsci (1999, 325-6) writes, "[p]hilosophy is criticism and the superseding of religion and 'common' sense." In this way philosophy coincides with 'good' sense, a reflexive or conscious form of knowledge. In contrast, insights resulting from common sense are premised upon the sedimentation of an unrevealed knowledge. Oftentimes contradictory, common sense forms the basis for consent and dissent and potentially results in a supremacist or even hegemonic formation.

Supremacist, and would-be hegemonic forces, draw on seemingly transcendental truths that emanate from common sense understandings of the world and the ethical commitments these entail. As Gramsci $(1999,326-327)$ states, “...the co-existence of two conceptions of the world...is not simply a product of selfdeception...it signifies that the social group in question may indeed have its own conception of the world." On one level, the consent for and dissent from disciplinary neoliberal supremacy seen in the United States is a disordered arrangement that cannot be reduced to a single domain such as economics or a theoretical 
"-ism." On another and more radical level, it suggests that consent and dissent is forthcoming in part due to pre-reflexive knowledge. Within the context of the TPM, I argue that this pre-reflexive knowledge forms a sedimented knowledge and emanates from the hails and subsequent interpellation of three supremacist discourses: the nationalist-patriotic, religious-moral and free market capitalist.

Louis Althusser (1971) posits that an individual is hailed and interpellated by ideological structures (e.g., the state, religious institutions) when one recognizes oneself as the subject of the hailing. Althusser $(1971,163)$ uses the example of a police officer who hails a passerby by calling out, 'hey you there!'. By turning and responding one becomes subject to and thus interpellated by the hail. Žižek (2008, 113-114) adds to Althusser's argument by describing these institutions in less material form as the "big Other". It is to these three mirroring discourses I turn next.

\section{Nationalist-Patriot Discourses}

Tea Party activists combine a unique nationalism-patriotism-a hyphenated convergence of both nationalism (i.e., a strong exclusionary identification with a single political entity such as the United States) and patriotism (i.e., devotion to the nation). This is exemplified by their unwavering belief in American exceptionalism. American exceptionalism, as a concept, is well-documented and includes a rationale of American engagement in the world predicated on the unique planetary position articulated in phrases such as "the shining city upon a hill" used during the Reagan presidency, and more recently, "the indispensable nation" employed during the Clinton and Obama presidencies. What combines these is the notion of the United States as the world's moral compass. Nevertheless, American morality has been shaken in the twenty-first century. It is in this context that the TPM seeks to restore American exceptionalism. As Meckler and Martin (2012, 13-14) note,

....and we wanted to take the country back from the political class... We felt helpless as we watched our beloved nation - the greatest nation in world history-slip away... But most of all we felt isolated in our belief that America was special, exceptional, a shining city upon a hill....It was missing from the values of the political class, who had abandoned the principles that allowed America to create more wealth and freedom than any nation the world has ever seen before.

American exceptionalism conveys a sense that the United States is the chosen nation (Schesinger, 1977). Seymour Martin Lipset $(1996,19)$ identified five terms that define the idea of the United States: freedom, equality, individualism, populism, and laissez-faire. These attributes are said to be unique to the United States and understood to be universally valued and sought after. Developing out of this 
is the belief that the U.S. is a redeemer nation with a millennial mission. This has implications for subjectivity, as the individual who looks out at their world sees that they and their nation have been called upon by God to be the lead nation in a world of increasingly stark choices.

The covenant the TPM experiences regarding their mission from God reinforces neoliberal supremacy by producing loyalty as an ethical debt to the nation and God. Changing the world to better suit neoliberal supremacy by making the world more consistent with so-called American ethics is therefore an explicit component of TPM nationalism-patriotism. This belief has serious consequences, in particular, for on-going American military adventurism. It also serves to dampen internal criticism with the simple assertion of being un-American.

While understanding American exceptionalism at an international level is critical to understanding the American identity that is sought after by the TPM, the idea also impacts this identity at the individual level. There is, within the social imaginary, a parallel drawn between the United States as a single autonomous entity and the individual as a single autonomous entity. In other words, there is a conception of the liberal autonomous individual as a desirable universal subjectivity forming the ethical All-American. Parallel to this is the idea of the nation as the embodiment of the ethical All-American as it interacts with other states across the planet.

This understanding of what it means to be American compels Tea Party activists to, for example, posit education as critical to individual and American exceptionalism. Meckler and Martin $(2012,147)$ write,

Our children should be taught not only that our system is the best, but also that other systems-like socialism or communism-are not the best and, in fact, are not even good. American children should be taught that those systems of government are bad at best and evil at worst. And the fact that that sounds even remotely controversial proves how far American education has drifted from the truth.

The path to exceptionalism is strikingly similar to individual success within the capitalist market system. Rewards and punishments are necessitated in order to incentivize education stakeholders to produce these exceptional individuals-to produce ethical All-Americans and to ensure American exceptionalism.

It is important to note that nationalist-patriotic sentiment is not imposed by the state upon an unwitting public. Rather, the sentiment is embedded within the hailed non-subject. An example of this embeddedness is the extent to which Americans in general, and Tea Party activists specifically, participate in the voluntary sector and other informal civic organizations. The voluntary sector and civic volunteerism are significant for two primary reasons. First, they confer 
ethical meaning and a common sense understanding of how to be subject-inthe-world through public work. In this conception, shortcomings, such as poverty for example, should be dealt with at the individual level through the community. The government, they argue, should not be involved-typical neo-conservative perspectives. Second, participation in these spheres elicits a deeply believed and uncoerced sense of patriotism-nationalism. Contrary to liberal views, the TPM characterizes government spending on social programs as at best ineffective and at worst contrary to the U.S. constitution and Biblical teaching. Tea Party activists believe it is the role of religious organizations, nonprofit organizations, corporations, and individuals to provide welfare services. Welfare services are an issue of personal responsibility on the part of the receiver as well as the provider.

This shapes the TPM critique of how the American government and Federal Reserve responded to the 2008 crisis (e.g., quantitative easing, interest rates, deficit financing, infrastructure investments, extension of unemployment benefits). The critique is more than simply economic policy preferences. Instead it is about protecting the border, the constitution, and is meant to send a message for a return to a more stringent and "pure" neoliberal America. As Michelle Malkin (O'Hara and Malkin 2010, XXIII) declares,

There are two Americas. One America is full of moochers, big and small, corporate and individual, trampling over themselves with their hands out demanding endless bailouts. The other America is full of disgusted, hardworking citizens getting sick of being played for chumps and punished for practicing personal responsibility.

The nationalism-patriotism displayed by the TPM is in part reducible to the ideals contained within what Robert Bellah (1967) called the "American civic religion," which comprises constitutionalism, democracy, and liberty. Sufficiently vague, this religious outlook reinforces the commonsensical view that American leadership in the world is a natural outcome and universal in its appeal. Within this narrative, then, the United States is the lone ethical savior who assists helpless communities and yet remains a constant outsider (Jewett and Lawrence 2003). Threats are always manifestations of evil. Liberty can only be saved through the courage and strength of a democracy that is willing to transgress its own laws so that evil can be destroyed-a duty the United States carries out with an aura of benevolence (Fousek 2000).

It is important to note that exceptionalism is not another word for being distinct. As Daniel Bell (1991) argued, American exceptionalism is predicated on nationalist notions of the superiority of Americans and American institutions. Having embraced this understanding, the TPM have turned inwards, arguing that the United States, since the Obama administration took office, suffers from what 
Tea Party strategist Michael Prell (2011) describes as "underdogism." Prell reinforces a view common within the TPM, that President Obama is not only unwilling to wield American power but also suffers from a form of false consciousness. President Obama, and more broadly the Democrats, identify with the powerless over the powerful by assigning virtue to the former. This false consciousness, by extension, has transformed U.S. foreign policy into apologies for the exercising of American power. For the TPM, the Obama presidency embodies the antithesis of American exceptionalism, affirming the fears of American decline and increased precariousness on an individual and global scale.

In contrast, the Bush administration's waging of the "War on Terror" provided the American public with the symptom for what ailed the United States at the beginning of the twenty-first century. The Muslim terrorist came to embody the contradictions and economic difficulties that beset the United States after the technology stock market collapse of 2000 as well as its growing socio-economic inequalities. Social cohesion was made possible by the wide consensus that the terrorist attacks of 2001 were the cause of these difficulties. Once the cause was eliminated, America would be healed.

The 2008 election of an African-American president, the shift away from the "War on Terror," and the deepening of the financial crisis through 2009 quickly transformed the Obama administration into the source of American ailments. Believing that the United States is a coherent, autonomous, and unified national space, any interruption must be the consequence of some un-American agent. It is an interesting scenario; what becomes clear is that nationalism-patriotism is geared not only towards a perceived hostile world (e.g., terrorists), but also inwards towards an administration that is seen as the antithesis of the ethical All-American identification.

Ghassan Hage (1998) makes a significant point that the nationalist-patriotism discussed here cannot be understood without its racial context. There has been substantial public discussion of Barack Obama as the first African-American president and the racist overtures towards his presidency. Hage, however, provides a critical articulation that contextualizes the ethical All-American identification that is sought after by the TPM. It is one of white privilege. Hage $(1998,45)$ argues, "[ $t$ ]he (white) nationalist who believes him or herself to 'belong' to a nation, in the sense of being part of it, means that he or she expects the right to benefit from the nation's resources, to 'fit into it,' or to 'feel at home within it."' Hage goes on to argue that this ability to imagine inhabiting what he refers to as the "state's will" makes it possible for white nationalists to imagine that they themselves enact the will of the state. The TPM exemplifies this as activists who firmly believe that their "...founding 
principles are the same as America's. These beliefs are in America's DNA; they are each American's birthright." They go on to say, "[w]e know who should be running the country: patriots, just like you" (Meckler and Martin 2012, 24).

\section{Religious-Moral Discourses}

The connection between the TPM and Christian conservatives, in particular evangelical Christians, has not gone unnoticed. $75 \%$ of Tea Party activists describe themselves as Christian conservatives. Nearly half (47\%) are actively involved in a religious-right or Christian conservative organization (Public Religion Research Institute, 2011). David Brody (2012), author of the book Teavangelicals, provides a succinct explanation as to why the two social groupings have considerable overlap. As he indicates, one of the primary reasons is the fiscally conservative message of the TPM resonates with evangelical Christians and other Christian denominations as it is based not only on economic argumentation but also on moral ones. What both assume is a permanent connection between religiosity and morality. In other words, one cannot be moral without being religious and vice versa. Binding the two together is the common sense understanding of religious and moral truths as objectively determined. This is truth with a capital " $\mathrm{T}$ " and is beyond the realm of human intervention. Both Tea Party activists and the evangelical Christianright, maintain that their ethical authority stems from their literal interpretation of the "Truth" that is contained within the American constitution and the Bible.

The Bible's truths, it is argued, are so clear that there is no need for interpretation by a religious or educated elite. As Scripture is considered to be accessible to all, it therefore lends itself to be employed in a politics that reinforces the idea of commonsensical truths without deviation. With right and wrong so clearly demarcated, there is no need to create laws but only to (re)discover and apply self-evident truths. For Tea Party activists, the origins of the U.S. constitution are found within the Federalist Papers and Declaration of Independence. Ultimately, however, these are informed by Judeo-Christian principles. It was the hand of God and not simply the rule of law, for example, that resulted in the rights spelled out in the Declaration of Independence. This religious-moral understanding finds its expression in the TPMs call for a return to a constitutionally limited form of government. The TPM favors a constitutionally limited government because it is the ethical choice. Government, it is argued, spends money without knowing what is of value to individuals. Welfare programs provide a succinct example, as they are considered to be promoters of unethical behaviors. The TPM maintains that government spending underwrites and validates unethical behaviors such as unbiblical co-habitation, pre-marital sex, abortions, and single parent families (Pease 2010). 
Within this understanding, unwed single parents lead an unethical life. Government welfare programs contribute to this as they provide a seeming "lifestyle subsidy" to those living their lives beyond the bounds of so-called traditional family values (Carlson, 2005). Governments, through taxation, erroneously compel individuals to pay for government programs that financially support and ethically promote what the TPM sees as nontraditional lifestyles. Restricting this through a reduction in government is considered part of ethical policymaking. Furthermore, the TPM argues that government spending encourages further spending, not less. Pointing to the Bible, Tea Party activist Jim DeMint (in Brody 2012, 24) maintains, "you can't have two masters." Based on this line of thinking, government, as "master," is inversely correlated with belief in God and, subsequently, ethics. In other words, the termination of welfare benefits and a reduction in government is not solely an economic calculus but a religious-moral one as well.

In reference to the U.S. constitution, the TPM point to "cowboy ethics" (Meckler and Martin 2012, 5). The cowboy epitomizes ethical behavior, reducing the world to right and wrong. Appearing around 1867 to 1890, during the Texas cattle drives, the cowboy has become an everlasting feature of American mythology and the subject of many Hollywood movies (Kleinfeld and Kleinfeld, 2004). Much of what is understood of the cowboy is a commonsensical understanding. Missing from the narrative is the historical context of a speculative cattle boom that was triggered by the massive influx of industrial workers in the northern United States. Instead, the narrative is of a self-reliant ethical All-American riding the frontier on horseback with a pistol, taking the law into his own hands to ensure it is observed.

It comes as no surprise that the cowboy, the consummate outsider and individual who transgresses the law in order to enforce it, helps formulate the image of the TPM. For the TPM, ethical absolutes ought to regulate both private and public as well as domestic and foreign conduct. To act otherwise has been to invite tragedy; a tragedy that is evidenced, for the TPM, by the passage of the sixteenth and seventeenth amendments (Meckler and Martin 2012, 82-87). The sixteenth amendment introduced the federal income tax, and the seventeenth amendment ended the election of senators through state legislatures and instead provided for their direct election by citizens. Both amendments, the TPM points out, have resulted in excessive power being allocated to the federal government.

The Founding Fathers, Tea Party activists argue, understood human nature and designed a system of government that took it into account. Citizens would need protection from the unchecked power of the sovereign. Citizens would also require protection from majority rule. The majority form the mainstream culture that the TPM understand to be unethical and consequently un-American. Self-identifying 
as outsiders, the TPM effectively see themselves as cowboys in defense of a religiousmoral worldview that the majority culture has forsaken. The majority culture, they maintain, continues to support an activist welfare state that has not only encroached on political freedoms but also increasingly on economic freedoms.

\section{Free-Market, Capitalist Discourses}

Tea Party activists maintain that wealth should be valued not because it serves to overcome inequalities, but because it provides sufficient proof of the virtuous nature of free market capitalism. This understanding is not only applicable to the United States, but is said to be a global truth. The capitalist free market is assumed to be the preeminent means for the allocation of resources and determining impartial and just outcomes. The basis of this understanding for the TPM is to be found in the U.S. constitution as well as the Bible.

Tea Party activists argue that the US constitution provides individuals with personal liberty. Individuals, as sovereign individuals, are capable of making choices within the economic marketplace for goods and services. That is not to say that Tea Party activists believe everyone will succeed and accumulate wealth. Instead, they believe the free market provides the opportunity to both succeed and to fail (Meckler and Martin 2012, 40). Failure, though, does not imply an end per se, but rather is a signal to try something else. In other words, failure is not considered to be the opposite of success. Instead, it is a necessary part of a capitalist system that functions on the assumption of risk. This belief in risk suggests that the capitalist market becomes the primary means for determining success or failure. Governments, in turn, distort the functioning of the market. The TPM therefore delimits the role of government as one of law enforcement, domestically and globally, in order to facilitate the proper allocation of risks and rewards.

Biblical foundations for TPM faith in free market capitalism are found in direct divine intervention. In this understanding, the invisible hand that Adam Smith (1965) identified in the operation of the capitalist market becomes the hand of God. The TPM assumes this connection as they argue that God places within each individual an ethical sensibility. Free then refers to the removal of corrupting forces such as governments from the capitalist market. It also refers to individuals who are considered to be free to make ethical choices. The outcomes are not predetermined but rather are results of the autonomy granted to individuals within the purview of an ethical God. Former aide to Senator Ron Paul and Biblical economist Gary North (quoted in Brody 2012, 38) summarizes it in this way, "the Bible provides the moral foundation of free-market voluntarism. The moral issue is personal responsibility. The Bible places this squarely on the shoulders of the 
individual decision-maker." The hero of this ethical free market capitalism is the self-interested and self-reliant individual. The self-interested butcher discussed by Adam Smith $(1965,14)$ meets the cowboy and is not simply guided by the invisible hand of the market but by the hand of God.

To restate the argument as I have posed it thus far, I suggest that the ideological commitment of the TPM can be traced, in part, to theorists such as Adam Smith. It is also traceable to the frontier experience and the myth of rugged individualism displayed by the cowboy and settlers making their way westward after the 1803 Louisiana Purchase. Land claimed through military force and other coercive means made way for individuals who sought to assert their property rights. Provided with an opportunity to become property owners, the Louisiana Purchase afforded would be settlers with a second chance (Moen 2003). The abundance was considered to be a consequence of God favoring of the United States and as such part of its manifest destiny. It translated into an ethical imperative to take possession of the territory and through the application of individual labor transform it into private property. The TPM updates this, arguing that what is good for laboring entrepreneurs, who are challenged by a different type of frontier, is also good for the United States and fulfills its ethical commitment to God.

The crisis of 2008 therefore is not thought to be one of free market capitalist failure, but one of excessive government intervention in the economy (O'Hara, 2010). The excesses point to a shift away from the common sense principles of the American experience, the US constitution, and the Bible. As Meckler and Martin $(2012,7,8)$ recount,

On December 16, 2008, Pres. George Bush appeared on CNN and actually said, 'I've abandon free-market principles to save the free-market system.' A Republican president had openly repudiated the free-market capitalism that had been the engine of liberty and freedom in the world. My heart sank for the first time in my life. I thought the end of American prosperity, ultimately democracy, might be at hand. With the election of President Barack Obama, things only seemed to get worse... It seemed that socialism in America was openly and rapidly on the march in our own time.

The discourse of the TPM finds blame for the crisis not in the global capitalist system or in the longer-term trend of the decline of the West and the rise of the rest. Instead, the blame is filtered through the above-discussed lens that found fault with greedy individuals, an un-American liberal elite, and the policies of a president often referred to as "Dear leader." For the TPM, the essential trade-off between risk and reward that they believe forms a universal truism has been abandoned. In its place has come massive government intervention to save large corporations in the so-called "too big to fail" bailouts of 2009. By intervening 
the government, according to the TPM, has effectively created two classes of Americans-small entrepreneurs and large corporations. They understand this divide to be more readily understood as being between those who accept the discipline of God, market, and nation and those who exceed it. When describing the personal impact of the crisis on Jenny Beth Martin's household, Meckler and Martin (2012, 1-3) summarize it as follows:

Lee ran a successful temporary staffing business. I work part-time. We bought the house same way our parents bought theirs: with a big down payment, credit checks at the bank, and monthly payments that were within our means... We didn't think we deserved a bailout. Like most Americans, we believe in taking responsibility for our own situation in life. When Lee's business collapsed, we did not look to the government for a bailout. We looked at each other and to our faith in God for strength.

She goes on to write,

Lee and I had been raised to respect the value of hard work and self-reliance. We grew up in a country where, if you applied yourself and work hard, you could live the American dream. We were living that dream before it turned into a nightmare. But we never lost our faith that America is the land of opportunity: the best place in the world to go broke and start over.

Tea Party activists maintain that the persistence and depth of the crisis was a direct result of the lack of discipline shown by many segments of American society, including large businesses and the federal government. The analogy employed by the TPM to make sense of the persistence and depth of the current downturn is the sports car. Activists argue that the economy is set to accelerate but is inhibited from doing so due to the actions of political elites, from both political parties, in Washington. In the case of the Republican Party, the TPM accuses the Republican leadership of being RHINOs- "Republican in Name Only." The TPM asserts that the Democratic Party, and the Presidency of Barack Obama, is undertaking actions that undermine the very existence of the United States.

It is not difficult to see how Tea Party activists see the government as an enemy of both the individual and the nation. Any form of political compromise falls short of their vision of a capitalist free market system. Compromise is not considered a political necessity. Instead, it is considered to be un-American, as the self-evident truths of the constitution and Bible require strict adherence. It is from within this commonsensical understanding that the TPM consider President Obama to be either inept or a traitor of the United States. President Obama has become the ultimate other, as he signifies one of the primary symptoms of what is wrong within the United States. However, it is also not outside the realm of possibility that Tea Party activists could find other scapegoats as they divide the world into one consisting of ethical All-Americans and their others. 


\section{All Hail the Ethical All-American}

The previous sections discussed the three key discourses shaping the TPM. But how is it that these discourses elicit consent and dissent within this ethical AllAmerican non-subject? Psychoanalyst Jacques Lacan $(1977,1-7)$ defined a moment when individuals recognize themselves as exterior to themselves, as reflected in language and image. In that instance of self-recognition, that is, of epistemological construction in the mirror, the "I" becomes a non-subject. It is instead an entity divided between a physical body and the idealized image (or idealized-I) contained within the mirror. He refers to this moment as the mirror stage. I argue that the process by which the ethical All-American non-subject is hailed by the forces within disciplinary neoliberalism is also a mirror phase. It is a moment when the "I" becomes psychically divided between a physical body and an idealized-I, as depicted in the free market capitalist, religious-moral, and nationalist-patriot mirrors.

Adherence to the free market capitalist mirror, for example, inscribes the individual to one facet of the idealized-I that is the ethical All-American. Choices, including those that bring about personal deprivation, made within the market are seen to be ethical choices, as market discipline forms a higher and more impartial way of dictating outcomes. By giving up on their desire and (instead) adopting the desire of the free market capitalist mirror, Tea Party activists assume their participation in an ethical system. The exteriority of the mirrors, however, introduces both a spatial and temporal indeterminacy that the non-subject is unable to overcome. In other words, the non-subject is unable to truly attain the idealized image reflected in the mirrors. Despite their alienation, the non-subject is fascinated by what they see and acts to shape themselves according to these supremacist discourses. The individual strives to overcome the fissure between the eye that sees and the idealized-I that is seen in the mirrors.

This is the uncanny disciplinary moment when non-subjects see what it means to be a subject-in-the-world and grant their consent. It is also the moment when they recognize the disjunction between the idealized-I and the world they perceive around them. In this moment, dissent may manifest in place of consent. TPM dissent is an attempt to re-affirm identity and to recoup a sense of ontological security that the non-subject feels is threatened by current transformations within the United States and the global political economy. TPM dissent seeks to reaffirm the supremacist discourses that had previously formed the basis of their consent.

In neo-Gramscian terms, the mirrors form the basis for the potential construction of multiple common sense worldviews that enable individuals to believe they are the authors of their own individual lives. Within the dialectical process, the self 
can only make sense of itself in relation to the big Other contained within the mirror. The big Other within a Lacanian framework is not the reflection of the subject contained within the mirror. Nor is it the other discussed within post-colonial theory. Instead, it is associated with language that emanates from the mirrors. The big Other forms the law and structures individual desire. In other words, Lacan defines desire not as stemming from an atomized individual but rather as always of the big Other (Homer 2005, 103). Individuals are then compelled to fill the gap between the self and the idealized-I by asking what is it that the big Other desires of me while assuming that this desire as their own.

Combining Gramsci and Lacan, we can see that, within the rubric of the ethical All-American, the idealized-I, as reflected in the three mirrors, incites the hailed to organize themselves around a desirable ethical center. This provides the individual with a sense of ontological security and a means by which to act in the world. By doing so, the individual is implicitly promised a subject position that is both ethical and complete. Again from Gramscian and Lacanian matrices, this subject position is at best a futile proposition and at worst provides for disastrous personal and political outcomes. For Lacan, there is only one subject position that can effectively structure the non-subject within the contingencies of their history and that is the permanence of the divided subject. The individual can never reduce the gap between themselves and the idealized-I. The significance of this for the TPM is that Lacan informs us that the individual can never be ethical or complete. As desire is the desire of the Other, the divided subject is caught within a structure of endlessly shifting signifiers. The relationship between the hailed and the reflected idealized-I within the mirrors is one of fundamental lack and a basic alienation that condemns the hailed to the constancy of being hailed through a politics of fantasy and resentment.

\section{A Different Political Economy?: The Ethical All-American and the Fantasy-Past America}

Lack is a necessary foundation of identity and it arises not from within the individual but is more profoundly part of the human condition. While the non-subject assumes the big Other, for example, to be without lack even here we find the opposite. As Slavoj Žižek $(1992,58)$ points out,

[o]ne can only wonder at the fact that even some Lacanians reduce psychoanalysis to a kind of heroic assumption of a necessary, constitutive sacrifice...Lacan is as far as possible from such an ethic of heroic sacrifice: the lack to be assumed by the subject is not its own but that of the Other, which is something incomparably more unbearable. 
In this chapter I have defined the big Other as the idealized-I, as depicted within the mirrors that hail Tea Party activists. As a means of compensating for the lack, the non-subject activist strives toward the idealized-I and its promise of subjective completion. In seeking this impossibility, of being the ethical All-American, the non-subject employs fantasy as the means of overcoming the gap between what they are and what they seek to be. In Lacanian theory, fantasy implies "some nonsensical, pre-ideological kernel of enjoyment that must be located and worked through" (Žižek 1989, 124-125). In this instance, the enjoyment is the possibility of ethical All-American subjecthood.

Fantasy, though, is not voluntary. It is a demand, as it constitutes the Other as having the capacity to satisfy the individual's need for subjective completion. Fantasy has a shielding and conservative function. It cloaks the implausibility of attaining subjective wholeness through the elimination of the gap between the hailed nonsubject and the idealized-I emanating from the mirrors. At the same time, fantasy is productive of a political economy of supremacy or hegemony as it unites what is and what ought to be. Within the context of the American disciplinary neoliberal model there are two iterations of fantasy. The first refers to a spatial horizon, the second to a historical utopia. Both constitute what I refer to as fantasy-past-America.

The first interpretation of fantasy-past-America is future-oriented and spatially expansive. It makes use of the word "past" as indicating just beyond; fantasy is just beyond reach both temporally and spatially. This iteration of fantasy-pastAmerica includes the reflections of Alexis de Tocqueville (2000), the frontier people's domestication of the "wild west," the mythical proportions of the immigrant American story, the ascendancy of the entrepreneurial spirit, and the formation of the United States as the manufacturing "workshop of the world."

The three mirrors are historically rooted. Dating back to the observations by Tocqueville, to the opening of the Western frontier, and to the mass immigration of peoples to the United States the mirrors signified the perceived birth of a New Canaan, American institutional superiority, and the triumph of "laissez faire" capitalism. Together these would form a new common sense view that individual fulfillment would arrive in the undiscovered terrain of a wide-open future and nation. In other words, this fantasy would form American exceptionalism and Manifest Destiny in spatial and temporal terms. This specific manifestation of fantasy-past-America can be more appropriately understood as evolving into a hegemonic formation.

I am not arguing that dissent did not occur. It did. Nor am I positing that the mirrors, themselves, were without lack. They were. Instead, I suggest that dissent was incorporated within the very structuring of the nation as a means of resisting big government, hierarchy, and by extension the concentration of power. The 
Puritan emphasis on individual responsibility, for example, was perceived as pleasing God, who in turn provided the new Americans with an abundance of natural resources. By extension, collectivist forms of dissent were actively suppressed, as this future-oriented and spatially expansive fantasy reduced the effectiveness of these sorts of articulations.

Furthermore, this manifestation of fantasy-past-America insisted upon the elimination of alterity through omission, active suppression, or incorporation. In the social imagination, therefore, there existed a vision of a future potential of wealth, of the attainment of property, and more generally of the attainment of the publicly venerated "American Dream" without the intrusion of otherness. This manifestation of fantasy-past-America was ascendant from the early days of the Republic through to the Second World War. Its apex was the Cold War with American cultural, diplomatic, economic, and military global leadership signifying national superiority (Caldwell, 2006).

At the beginning of the new millennium, there is a reworking and re-imagining of the fantasy-past-America. Supremacy, as configured within the rubric of the ethical All-American identification, is indicative of this radical historical break. The shift underway now, in regards to fantasy-past-America, is towards the establishment of a nonexistent former America-a utopian "city upon a hill." It is a demand to reclaim and reinstate a lost America that can provide the possibility of subjecthood to the disciples of disciplinary neoliberal supremacy. The eventual aim is to establish a past utopian hegemony that can activate a United States without otherness. The Tea Party activists claim, the current administration is "...dimming the lights on the shining city upon a hill that had stood as a beacon of freedom, prosperity, and opportunity to the world since its founding" (Meckler and Martin 2012, 14). This analysis may be partially correct. The United States may have signified the qualities identified but it has also signified other less favorable ones as well. This though is a minor point. A more pressing one is the false assumption that prior administrations were without their own compromises and shortcomings. In Lacanian terms the Tea Party activists assume a previously formed big Other without lack. Fantasy then continues to be the basis for consent and dissent within this historical conjuncture. It does so by conjuring up a mythical past that never was and can never be in anything other than fantasy. Yet, this is a critical transition in the collective imaginary.

The current iteration of fantasy-past-America speaks to disharmony, to the massive contradictions evident in the disciplinary neoliberal model. However, it also introduces harmony (past, future, and spatial) through the fantastic social construction of a United States without otherness. The mirrors are crucial in sustaining this drive. They promise to fulfill the fantasy-past-America and to restore America to 
the non-place utopia of a lack of a lack for both the individual and the supremacist social forces reflected in the hailing mirrors.

The TPM demand for a fantasy-past-America is a direct result of the inability of the hailing mirrors to eliminate individual lack and the on-going irruptions of hyper-contradictions into the everyday lives of Americans. This inability, however, as evidenced by the TPM, does not simply point to crisis and dissent that can lead to the potential displacement of the disciplinary neoliberal model. Dissent is not confined to the articulation of and implementation of alternatives in times of crisis. It must be seen that dissent also points to the constitution of the ethical AllAmerican. While inherently unattainable, TPM dissent seeking the achievement of the ethical All-American subjectivity is productive of perpetuating ontological crises yielding a politics of supremacy.

\section{Afterward}

The demand by the TPM activists to see themselves as reflective of the ethical All-American identification necessitates the fantasy-past-America. This is why TPM dissent calls for more disciplinary neoliberalism and not its displacement.

Fantasy-past-America is the central means by which the gap between individuals hailed by the desire emanating from the religious-moral, free market capitalist, and nationalist-patriotic mirrors are seemingly overcome. Enabling the appearance of subjective completion as ethical All-Americans, dissent is enjoyable for TPM activists. Fantasy does the hard work of displacing the hyper-contradictions of disciplinary neoliberalism onto the "other(s)," such as President Obama, liberals, the illegal migrant, foreigners in general, college students, Democrats, gays and lesbians, and climate change activists. By rendering the "other" as the reason for the incursions of contradictions, the ethical All-American, in conjunction with the signifiers presented in the mirrors, reanimates the power of fantasypast-America in an enduring circuit. Put another way, while it is assumed that the existence of contradictions within a model of development is a catalyst for dissenting transformation, the American disciplinary neoliberal model retains its supremacy because of and not despite its contradictions.

\section{References}

Althusser, Louis. 1971. Lenin and Philosophy and Other Essays. Trans. Ben Brewster. New York: Monthly Review Press.

Arceneaux, Kevin and Stephen P. Nicholson. 2012. "Who Wants to Have a Tea Party?: The Who, What, and Why of the Tea Party Movement." Political Science and Politics 45(4): 700-710. 
Bell, Daniel. 1991. “The 'Hegelian Secret': Civil Society and American Exceptionalism." In Is America Different? A New Look at American Exceptionalism, ed. Byron E. Shafer, 46-70. Oxford: Clarendon Press.

Bellah, Robert N. 1967. “Civil Religion in America." Daedalus 96 (1): 1-21.

Braudel, Fernand. 1979. The Structures of Everyday Life: The Limits of the Possible. Trans. Siân Reynolds. New York: Harper and Row Publishers.

Brody, David. 2012. The Teavangelicals. Grand Rapids: Zondervan.

Caldwell, Wilber W. 2006. American Narcissism: The Myth of National Superiority. New York: Algora Publishing.

Carlson, Allan. 2005. "The Natural Family Meets the Moral Hazard at National Health Care Gulch.” Accessed October 08, 2013. http://profam.org/docs/acc/ the acc frc 050126.htm.

de Tocqueville, Alexis. 2000. Democracy in America. Trans. Harvey C. Mansfield and Delba Winthrop. Chicago: Chicago University Press.

Fousek, John. 2000. To Lead the World: American Nationalism and the Cultural Roots of the Cold War. Chapel Hill: University of North Carolina Press.

Gill, Stephen. 1995. "Globalisation, Market Civilisation, and Disciplinary Neoliberalism.” Millennium 23 (3): 399-423.

Gill, Stephen. 2008. Power and Resistance in the New World Order. $2^{\text {nd }}$ ed. New York: Palgrave Macmillan.

Gramsci, Antonio. 1999. Selections from the Prison Notebooks. Trans. Quentin Hoare and Geoffrey Nowell Smith. New York: International Publishers.

Hage, Ghassan. 1998. White Nation: Fantasies of White Supremacy in a Multicultural Society. Sydney: Pluto Press.

Hammond, John L. 2003. "Another World Is Possible: Report from Porto Alegre." Latin American Perspectives 30: 3-11.

Homer, Sean. 2005. Jacques Lacan. New York: Routledge.

Jewett, Robert and John Shelton Lawrence. 2003. Captain America and the Crusade against Evil: The Dilemmas of Zealous Nationalism. Grand Rapids: William B. Eerdmans Publishing Company.

Kabaservice, Geoffrey. 2013. The Downfall of Moderation and the Destruction of the Republican Party, from Eisenhower to the Tea Party. New York: Oxford University Press.

Kleinfeld, Judy and Andrew Kleinfeld. 2004. "Cowboy Nation and American Character." Society 41 (3): 43-50.

Krugman, Paul. 2009. “Tea Parties Forever." The New York Times (April 12). http:// www.nytimes.com/2009/04/13/opinion/13krugman.html?_r=0sec. 
Lacan, Jacques. 2006. Écrits. Trans. Bruce Fink. New York: W.W. Norton \& Company. Lipset, Seymour Martin. 1996. American Exceptionalism: A Double-Edged Sword. New York: W.W. Norton.

Martin, Isaac William. 2013. Rich People's Movements: Grassroots Campaigns to Untax the One Percent. Oxford: Oxford University Press.

Meckler, Mark and Jenny Beth Martin. 2012. Tea Party Patriots: The Second American Revolution. New York: Henry Holt and Company.

Moen, Ole O. 2003. "The Frontier Myth in Modern American Politics." Journal of American Studies of Turkey 17: 79-92.

O'Hara, John and Michelle Malkin. 2010. A New American Tea Party: The Counterrevolution against Bailouts, Handouts, Reckless Spending, and More Taxes. Hoboken: John Wiley \& Sons, Inc.

Pease, Donald E. 2010. "States of Fantasy: Barack Obama versus the Tea Party Movement. Boundary 237: 89-105.

Prell, Michael. 2011. Underdogma: How America's Enemies Use Our Love for the Underdog to Trash American Power. Dallas: BenBella Books Inc.

Public Religion Research Institute. 2011. 2011 Values Voters Summit: The Alignment of Evangelical and Tea Party Values. Washington: Public Religion Research Institute.

Santelli, Rick. 2009. "Rick Santelli and the 'Rant of the Year"' YouTube video, 4:57, posted by "Todd Sullivan," February 19. https://www.youtube.com/ watch? $\mathrm{v}=\mathrm{bEZB} 4 \mathrm{taSE} \mathrm{A}$

Smith, Adam. 1965. Wealth of Nations. New York: Modern Library.

Tea Party Patriots. 2013. Our Vision. Accessed October 17. http://www.teapartypatriots. org/ourvision/

Williamson, Vanessa, Theda Skocpol and John Coggin. 2011. “The Tea Party and the Re-making of Republican Conservatism." Perspectives on Politics 9: 25-43. Žižek, Slavoj. 2008. In Defense of Lost Causes. New York: Verso.

Žižek, Slavoj. 1992. Enjoy your Symptom! Jacques Lacan in Hollywood and Out. New York: Routledge.

Žižek, Slavoj. 1989. The Sublime Object of Ideology. London: Pluto Press. 


\title{
Stephanie Sapiie ${ }^{1}$ \\ Intellectual Identity and Student Dissent in Indonesia in the 1970s
}

\begin{abstract}
This paper examines themes in student dissident activities in Indonesia (West Java) in the 1970s, a period which followed intense student involvement in the anti-communist movement of 1965-1966. The 1970s marked a new phase in student activism, defined by the rise of new leaders in the student-movement and the rise of intellectual criticism and dissent as a valued activist technique strategically suited to the growing authoritarian landscape of Indonesian politics.
\end{abstract}

Student dissent is central to the politics and history of modern Indonesia. During the late colonial period of the early 1920s, students were key figures in the anti-colonial nationalist movement. After independence in 1949, Indonesian state-universities saw a growth in regional student enrolment and a rise in political activity fuelled by political party-recruitment. In the mid-1960s, at a time when student activism was a global force for left-wing critiques of state power and war, Indonesian students were implicated in local campaigns of violence against the left-wing-the Indonesian Communist Party (PKI) - and supported the emergence of military rule. Despite the fact that these students were avid consumers of western popular culture, my paper shows that student dissent in the 1960s engaged with the ideologies of student activism in the West in unusual ways. For example, a recent interpretation of the student activist movement as an archetypal cowboy drama draws on a distinctly un-Indonesian image of the outlaw and reflects students' consumption of Americanmovies like Shane (As Indro Cahyono describes in Budiarso [2002]).

Ironically, as advocates for free-speech, Indonesian students in the 1960s generally advocated against Left-wing speech and were mobilized by what they saw as the irrationality Left-wing politics in the 1960s in Indonesia. Whereas in the United States the student free-speech movement occurred (in part) because students

1 This research was based on access to Indonesian archival sources and analysis of textual materials (student newspapers, journals, biographies, autobiographies) as well as 21 interviews with former activists in the student movement, as well as documents and compiled sources from the student-movement, carried out at the National Archives in Jakarta, the Masters' Library at Gadjah Mada University, and from collections of student newspapers from the 1970s housed at Cornell University's Kroch Library and at Columbia University in New York City. 
opposed the draft and the war in Vietnam, the issues of free speech that students in Indonesia cared about were markedly different. Students wanted neo-classical economics taught, for example. They wanted bans on foreign films and music lifted. Indonesian students expressed profound alienation from the state, and as Indonesian politics grew more authoritarian in the New Order under Suharto in the 1970s, Indonesian students increasingly withdrew from direct action in politics, choosing dissidence and dissident research as their main vehicle for the expression of oppositional thought.

Two dominant narratives shaped student-activism in the 1960s and 1970s. One narrative-that of the symbol of the student as nationalistic, heroic, and self-sacrificing-was central to the army's anti-communist campaign in 1966 and would become the basis for the student movement known as KAMI (United Action Front of Indonesian Students), a student Anti-Communist movement that has been described as a student-army partnership (Paget 1970; Boudreau 2004; Aspinall 2005). The violence against the Indonesian Communist Party (PKI) leadership carried out by vigilantes and armed-groups framed the anti-Communist student movement However, this violence was rooted in a particular intellectual discourse promoted often by figures within and part of the student movement. Universities provided the space and social networks for the recruitment of anticommunist intellectuals.

A second narrative about the student movement was one the New Order regime would actively promote through its early advocacy of intellectual discourse, academic freedom, and social-responsibility: that of a unique student civic-identity. This narrative had its roots in the Indonesian higher education system and was promoted by the state. By 1979, the state promoted a new policy called Campus Normalization that called on students to cease all political-activities. Campus Normalization represented a radical break from the regime's early alliance with the student movement in 1966. It reinforced several components of the New Order ideology of stability and order. First, a normal campus was one where students did not "demonstrate," where students' "engagement in politics" was permitted only at the level of "discourse," and where students' "discourse" did not strengthen or engage in mass action (Anwar 1977). Students' campus activities were limited to sports and culture- and art-based activities. NKK reversed the government's early tolerance for academic freedom, which Suharto, in his 1973 End of Year Address, had maintained "was beneficial to nation-building" (Suharto 1973).

Some of the earliest efforts to write about the student movement in Indonesia were by activists who participated in the KAMI protests (Bachtiar 1969), or by those who were observers of anti-communist mobilization at the University of 
Indonesia in 1966 (Gie 1966). This work describes well the numerous political, cultural, class, and religious divisions of the student movement: the diversity and conflict of campus-life mirrored the larger diversity and cleavages of Indonesian society. Yet the social, culture, and organizational nature of campus life obscured the cultural dynamics of the student movement, which had absorbed the inherited Dutch culture of Indonesian universities (they had started as Dutch schools, after all, to educate the non-Native population in the Indies) and the universities reflected this elite culture (Aminoedin, "Student Organizations in Indonesia," no date)

After the violence of 1965, a period during which most political organizations and mass-organizations confronted restrictions, students were the beneficiaries of the regime's good will. Student activism reciprocated, at first, with positive support for the army in 1966. However, by the early 1970s, dissatisfaction with the military regime became more abundant and students cautiously stepped around restrictions imposed on issues free-speech and individual rights to disagree or dissent with the regime. Student dissent reflected nationalist themes of Indonesian independence. While their nationalist credentials would lend them strong military-backing in the 1966 anti-communist movement, by the 1970s students generally confronted a more restrictive set of circumstances (Boudreau, 2004).

\section{The Political Context of Anti-Communism and the Rise of the New Order, 1965-1966}

Campus-mobilization in the 1960s reflected the general conflict occurring outside of campus-particularly the build-up of communist-concentrations and the public-works projects of groups and leaders affiliated with the PKI (Indonesian Communist Party), which in rural areas undertook massive public projects to improve schools, infrastructure, and local government. Beginning in 1965, after a steady growth of the power of the Indonesian Communist Party led to infiltration of units within the Air Force and in some army-units (Boudreau 2004 and Crouch 1978), the Indonesian military and paramilitary-organizations actively dismembered the Indonesian Communist Party (PKI) and their affiliated cultural associations and members. Campus student organizations affiliated with the PKI, like the Communist-Concentrations (CGMI), were banned.

In the immediate aftermath of the state-sanctioned violence that surged throughout Java and Bali from October to December 1965, anti-Communist student groups were seemingly nurtured by the new military-junta around General Suharto called the New Order. New student newspapers and student radio transmissions began in the capital, Jakarta, starting in January 1966 (described in some detail by Soe Hok-Gie's 1966 diary, Demonstration Notes [reprinted in 2005]). 
A new shift in the culture of student activism was evident. Student newspapers advertised student art exhibits and campus happenings (Steele 2005, 49). Students read poetry over radio stations that had once communicated strategic positions for Army commanders. While facilitated by the army, the student movement became something increasingly less controlled by the army. Whereas campus groups in Jakarta and Bandung in the pre-1965 era had found themselves at the epicenter of campus conflicts between pro-communist and anti-communist organizations, by the time the pro-PKI groups were eliminated in late 1965, student activist campaigns shifted. As early as January 1966, student dissent emerged as markedly academic, with students supporting new economic policies and marching in support of exiled neoliberal economists who spoke of introducing foreign directinvestment, lifting import bans, and enacting a shift away from price-controls (Bresnan 1993 and Soe Hok-Gie, 1966 [2005]).

New student newspapers took sides with the army's seizure of power against the Indonesian president, Sukarno (under house arrest from March 1966). Student editorials in the Army-backed newspaper, Indonesian Student (Raillon 1985) featured strongly worded statements in support of the Army's intent to remove all traces of Sukarno's influence from Indonesian campuses. Amidst this shift to military rule (a shift that has been documented as both brutal and savage, killing an estimated one million Indonesians) was a stranger phenomenon: the rise on-campus of a student-centered culture fashioned around student issues and personal concerns rather than partisan-based conflict. Raillon (1985) has documented this new print-culture of the student movement identifying the discourse and the transmission of anti-communist thought through this newspaper.

While the army's repression across campus included bans on any groups once allied with the PKI or the GMNI, this ban was limited in its reach on campuses. Spaces outside the regulation of state power soon emerged, including departmental study clubs and student-sponsored conferences, suggesting that within narrow parameters academic study was relatively un-infiltrated by the state. In fact, the new military regime promoted academic freedom, a move which legitimized university activities including the student-activism that arose within these academic conferences and student-initiated research and practice groups (some of which led to the early NGO movement by the late 1970s).

\section{Typologies of Student Dissent}

If the student dissent that emerged in the immediate aftermath of the PKIpurge could be characterized as at times spontaneous and exuberant, campus dissent movements in the early 1970s can be characterized as more markedly 
"contentious talk" in the manner described by Hank Johnston $(2005,115)$. These activities took place in private settings that stressed students' elite status "as intellectuals and /or scientists...to strategize ways to challenge regime policies" [and] to proclaim dissent and demonstrate it one way or another to compatriots" (Johnston, 2005, 115).

This shift was not simply one of ideology, it seemed to mark a shift in the practices of the movement itself, in which the movement generated a cultural style that fit or responded to the particular exercise of state-repression. Much of the student dissent in the post-1966 period fits Johnston's category of "informal politicized talk," $(2005,113)$ in which participants engage in speech that is broadly cognizant of what the regime will allow. Through the prism of personal experiences, the politicization of daily life and activist-responses to state repression are evident. This paper examines the activism of two different student dissenters whose activist careers differ significantly. The first student, Soe Hok-Gie, was a literature student at the University of Indonesia in 1966-at the beginning of the New Order. His younger brother, Arief Budiman, is today a prominent Indonesian academic and during the 1970s was an intellectual-critic of the New Order. Budiman was active during the early implementation of New Order-electoral reforms. His critique of the 1971 elections, the GOLPUT, or Golongan Putih (White Group), was Budiman's dissident campaign.

This paper then ends with the activist campaigns waged by student cohorts at the Institute of Technology in Bandung (West Java) in the mid-to-late 1970s. The individuals behind these actions include Student Chairman, Heri Akmadi and the Student-Councils of 1973-1974 and 1977-1978. These case-studies demonstrate different categories of dissent-whether as "informal politicized talk" or more modest forms of direct action - and demonstrate different cultural adaptations by students to differently repressive circumstances. If the army's 1965-1966 purge of Sukarno and Communist-ideology involved the empowerment of anti-communist student groups unaffiliated with political parties, the late 1970s demonstrates the potential impact of student empowerment. The military repression of 1978 ended the brief alliance between students and the modernizing military junta that students found uniquely appealing in 1966. It also marked the end of student-activism narrowly tailored to campus concerns. By the late 1970s, activism would end in campus repression that banned the few groups once allowed to express criticism: the Student-Councils. As activists found themselves contemplating exile from politics once more, new shifts in the student movement facilitated a shift towards greater populism and off-campus activism than had been experienced by the campus-based movement of the 1970s. 


\section{Indonesian Academic Culture: Sources of Dissidence}

Reading Western magazines, consuming Western culture, and generally immersing themselves in a world funded by American and British sponsorship, including lending-libraries established by the British Council, were all recreational activities that most Indonesian university students enjoyed throughout the 1960s. Ease in this cosmopolitan world was part of how Indonesian academics functioned (particularly since many had studied abroad). In contrast, while Sukarno was part of a generational cohort that had been educated at university abroad (often in the Netherlands), he was an exception to this practice, choosing instead a political career rooted in West Java with the newly-formed PNI (Indonesian National Party) in the 1920s (Adams 1960, Legge 1997 [2003]).

Traditionally, university training did not prepare one for a career in the academy but in politics or the civil-service. The purpose of university education throughout the Dutch era (and also, indeed, during the early years after independence) was to create a new administrative elite. The status conferred by a position within the civil service was one that suited the elite backgrounds of many of the university educated. However, while the civil service in the post-independence period continued to grow to 1.7 million, it failed to absorb most university graduates by the late to early 1960s (Smith and Carpenter 1974). University graduates were also increasingly alienated by the effect of Sukarno-era policies on university instruction and doctrine. The result, by 1961, was a student movement supported by many faculty and older academics alienated by a political process that had reduced the traditional status of intellectuals.

The process of constructing an oppositional consciousness in the early 1960s grew out of movement-communities that were based in the social networks of dissident intellectuals in Jakarta and Bandung, and which were rooted in the culturally-cosmopolitan circles that existed in Jakarta between literature-students, the military, writers and journalists. These circles were increasingly defined by individuals who professed the prestige of scientific knowledge and technical expertise. As Sukarno was viewed increasingly as an ideological puppet of the PKI, many dissidents sought refuge in study-circles and underground discussion groups held in and around Jakarta in the mid-1960s. Documented by Janet Steele's 2005 book about Indonesia's first newsweekly, Tempo (modelled on Time magazine), these circles involved a number of overlapping categories: students, journalists, writers, literature-professors, and contacts from the Congress for Cultural Freedom's Asia Program, which sponsored early anti-communist journals like Mochtar Lubis' Obor [Torch] (Steele 2005, 39). These discussion groups functioned less as activedissident groups than as dissident-spaces where disgruntled individuals gathered 
to talk and circulate readings. They functioned to sustain and nurture dissident intellectuals and their writing.

\section{Soe Hok-Gie: Adapting Personal Disgust and Rage into Political-Activism}

Soe Hok-Gie was a dissident figure who emerged in the student movement in the 1965 anti-Communist student movement known as KAMI (United Action Front of Indonesian Students). Soe Hok-Gie described much of the KAMI-activism in his journal, later published as Catatan Demonstran (Demonstration Notes, 1966 [Republished in in 2005]]). Soe Hok-Gie's journal is a primary source which documents events in Jakarta from January 15-January 30, 1966, a period during which KAMI was an active street presence. His journals describe the sometimes anarchic, sometimes joyous participation of students at the prominent University of Indonesia in Jakarta during January 1966.

The University of Indonesia in Jakarta had a history of student activism that dated back to medical-student activism in the late-1930s, during the period of Japanese occupation (Anderson 1972 [2006]). During the 1950s, the university was at the epicenter of Indonesian president Sukarno's political program known as Guided Democracy. The doctrine of higher education, revised continuously in the post-independence era, stressed the social obligations of individuals in the educational system. In 1950, the goal of education was outlined by the official mandate Tri Dharma, or "Three Pillars of Service of Education." The Tri Dharma specified the purpose of higher-education as 1) [to] educate, 2) [to]research, and 3) [to] provide community service...to create decent, capable human beings and democratic citizens who will be responsible for the welfare of society and our nation" (Buchori and Malik 2005, 257).

In an attempt to unify diverse and at times incompatible groups-nationalists, communists, traditionalist and modernist Muslims-the Indonesian president and former revolutionary leader Sukarno tried to promote Indonesian culture and identity throughout the 1950s. Following the 1957 parliamentary elections, which saw major gains by his party's major rival, the PKI (Indonesian Communist Party), Guided Democracy was a massive effort by Sukarno to exercise political control in an increasingly fractious political landscape. In West Java, where Sukarno's party, the PNI (Indonesian Nationalist Party), was based, opposition to the PKI was especially strong and evident among student groups. Increasingly, on campuses in West Java conflict escalated between nationalist and communist students.

Growth of the PKI had occurred outside the urban university milieu (McVey 1990). Almost all of the PKI's efforts from 1961 to 1964 had been in areas of rural 
development, education for training cadres, and organization of civilian 'fronts'. While the PKI's membership grew to 2 million by 1964, its base was not among left-leaning intellectuals, many of whom identified with PSI (Indonesian Socialist Party). University students, especially at ITB (and among somewhat PSI circles), saw themselves as more "western" and "modern". They were

not attracted to the PKI. Moreover, the idealists among them were alienated by the corruption and hypocrisies of Guided Democracy, and they considered the PKI particularly culpable for supporting that system ... as the post-coup student demonstrations would show, class attitudes and anti-establishment ideals combined among them to produce a virulent anti-communism." (McVey 1990, 20).

Students at ITB recounted how Sukarno's revolutionary ideology did not suit their sensibilities: "try telling an engineering student that two plus two equals fiveit doesn't work. That's how [it was]" (Syarief Tando quoted in Hasyrul Mochtar 1997, 493). Students' anti-communist beliefs were founded on hostility to new education reforms introduced in the early 1960s which emphasized goals of highereducation to include social responsibility and social justice. The shift from a goaloriented education to one defined by ideology as socially-oriented was not an easy shift for non-communist students to absorb.

Under the Regulation on Higher Education, No. 22, passed in 1961, schools were directed to "develop pupils' regard for both national and international morality and religious beliefs, intellectual, emotional and artistic lives, manual skills and physical health" (quoted in Murray $[1973,375]$ ). In a move that especially infuriated large segments of Islamic political parties, the re-revised Education Law in 1961 defined education's purpose as "the realization of an Indonesian socialist society... just and prosperous ... materially and spiritually" (Basis and Aim of Education in Free Indonesia, 1962). To Muslim political leaders and social reformers, the 1961 mandate was further evidence of PKI's outsize influence on national-policy. In fact, Sukarno's Minister of Education, Prijono, a professor of literature was appointed in 1957. A member of the left-leaning Murba party, his appointment was regarded as a nod towards the influence of the PKI (Douglas 1970, 6). Prijono's new mandates as Education Secretary further angered Muslim leaders by reducing religious instruction and mandating the instruction of "Social Education"- a curriculum that covered historical topics including "acquaintance with national heroes and holidays, the national language, flag, emblem and motto," (Douglas 1970, 67).

Sukarno's speeches on the Political-Manifesto were required reading at the highschool level and required for graduation from university. The poet Rendra recalled the contradictions in the national education policy, which had once promoted 
"humanistic education stressing a changing world view, developing an appreciation for objective facts...for logic... and appreciation of arts... and a teaching of compassion and charity through literature and poetry," an attitude abandoned in the 1960s for a policy akin to "slapstick comedy" (interview, Cohen 1999, 3). In the 1960s, students' attitudes shifted as they increasingly identified as 'modern' and "democratic" individuals in a society that was culturally "backwards" or "feudal."

By the early 1960s all groups were required to adopt a new official ideology called NASAKOM/Manipol-USDEK, or face an official ban. Manipol-USDEK stood for the Political-Manifesto [a reference to a speech made by Sukarno on August 17, 1959] in which he outlined a new political outline emphasizing nationalism and communism [NASAKOM] (Feith, 1962 [2007] 595). The USDEK was an Indonesian acronym which Sukarno constructed from "five essential points 1) the Indonesian constitution, 2) Indonesian socialism, 3) the ideology of Guided Democracy, 4) Indonesia’s State-Guided Economy, 5) Indonesian identity (Feith, 1962 [2007] 596). Campus events had to meet new ideological standards determined by guidelines outlined in 1961 in the mandate, the Political Manifesto (Manipol-USDEK). These sanctions curtailed students' ability to enjoy Western movies and music at campus carnivals or events. At campuses like ITB and UI students routinely enjoyed screening of foreign films, jazz nights, and art exhibitions. New prohibitions interfered with social and cultural campus life, including the ritual hazing inflicted on all first-year students-all were banned for being representative of foreign cultural influences.

Throughout the 1960s, the military increased its supervision over university affairs. Starting with the 1957 "Crush Malaysia!" campaign, university administrators required students' mandatory participation in drill exercises and daily marches (Douglas 1970, 75-76). Intellectual critiques of Guided Democracy that focused on the ideological requirements of the Political Manifesto were strongest among those who wrote and thought for a living. Journalists and writers regarded the MANIPOL-USDEK campaign as a restriction on free-expression (Steele 2005 35).

As a literature student and journalist, Soe Hok-Gie was part of a small underground circle of dissidents in the Literature department at the University of Indonesia, which included former professors of Economics, like Soejdatmoko, whom Soe Hok-Gie referred to as "Koko" in his diaries. Army historian Nugroho Notosusanto, employed at the University of Indonesia as a lecturer, tried to cultivate close relations with student activists, including Soe Hok-Gie. During periods when bus transportation was generally unavailable, Gie reported getting rides to and from the University of Indonesia to his house in the Kebon Sirih neighborhood of Jakarta from Notosusanto (Maxwell 2001, 132). 
Values emphasized in Gie's journals regarding his daily contact with ABRI generals in the post -coup period suggest that the officers embodied courage, professionalism, and pragmatism. For example, Gie recalled the following incident:

Nugroho is very aware. In 1958 was part of demonstrations in front of the French embassy against the colonial war in Algeria. He became very emotional about it and became very hot-tempered, banging the pencil sharpener on his desk as he recalled shouting 'Vive l'Algerie!"...He told us, 'every time I see that picture in my head at that demonstration I become that person." We spoke for a bit but it seemed we were embarrassing him, so we changed the subject (Maxwell 2001, 132).

Soe Hok-Gie had strong personal sentiments that were clearly opposed to Sukarno's self-aggrandizing style of politics. Sukarno, Soe Hok-Gie wrote, "only builds palaces; things that cannot be enjoyed by the people who are all hungry" (Maxwell 2001,12 ). In his critique of Sukarno's personal behavior Soe Hok-Gie quietly acknowledged the need for a new national culture from one under Sukarno that was corrupt and glorified power to one more individualistic and humanist (Soe Hok-Gie 1966 [2005], 138). Some intellectuals rallied, in anonymous manuscripts, around themes of illness and renewal (pembahruran) for 'reform" (Maxwell 2001, 138). The idea of renewal appealed to many, who like Gie who were both repulsed and fascinated by the president:

I remember meeting Bung Karno [Sukarno] three times at the palace. I looked at the female assistants he had working for him ... but I remember thinking, seeing his secretaries ... I knew just looking around that I didn't care for it. Yes, they were pretty but it seemed dirty and corrupt to me. Whenever I left the palace I felt sick and disappointed. (Demonstration Notes 1966 [2005] 126)

At a time when large, mass-membership organizations prevailed across campuses, Soe Hok-Gie's most lasting contribution in politics was his individual cultural criticism of Sukarno and the political extravagance of his administration. Soe Hok-Gie's own politics were shaped by his background as a Christian ChineseIndonesian who was on the periphery of politics and whose own anti-political politics was no doubt shaped by personal aspects of his identity.

Anderson's 1970 obituary of Soe Hok-Gie ("In Memoriam: Soe Hok-Gie,") suggests a different interpretation for the youth's anti-Sukarno opposition than that proposed by John Maxwell (Soe Hok-Gie's biographer). While Maxwell speculated that Soe Hok-Gie may have admired the armed forces for their heroics and ideals of sacrifice, Anderson instead argued that Soe Hok-Gie's

Fondness for the ideals for a modern democratic society were "encapsulated" by the spirit of modernization that seemed to lurk in both the ideals and values that students and the army shared in the pre-coup days. While Gie would go on to be very critical of the 
Army and the student-leaders in the post-coup period, the idea of 'modernization' did not mean for Gie what it meant for the military... Modernization...for him meant, above all liberation: liberation from hypocritical conventions and the degradation of accepted servitude. Being modern meant being able to stand up to those in power and see them for what they really are" (Anderson 1970, 227).

\section{The 1970s: The Landscape of Student-Dissent and the White-Group (GOLPUT) Campaign}

Compared to the landscape of the 1960s, where political parties aggressively recruited students, the campus in the New Order was a more sterile environment. While groups like GMNI and HMI continued to exist and recruit student members, the emerging leaders on campus were the elected representatives of the student-body on each campus: the Student Councils and Senates. The Student Councils were a product of reforms passed after independence by the Ministry of Education, Culture, and Instruction in 1947.

Medical students had lobbied for a system of student councils 'to discuss the possibility of establishing a general student union for coordinating student activities and for representing the student body (resembling a structure that existed on many "AngloAmerican universities"). The desire to create student councils had taken place in the 1950s out of desire to create 'indigenous' student organizations to combat the culture of "Dutch" social clubs (Augusdin Aminoedin, "Student Organizations in Indonesia," Date unknown).

Student Councils had legitimacy on campus; they had tried to improve student life. In Bandung, the Student Council lobbied for a branch of a local bank to be built on campus for students and for canteens on campus. In Jakarta, the student council undertook surveys of students in Jakarta (Salim 1954). It helped enormously that the Student Councils also had allies in the press. "The student press," Indro Cahyono (a former student-activist) told me, was "behind the promotion of the idea that students could articulate the peoples' aspirations. It was the student journalists who most distrusted the political process" (Interview by author with Indro Cahyono Jakarta, June 2002).

Press coverage aided student mobilization efforts. Each time the press published a petition or was in attendance at a Student Council seminar, the story that followed helped promote the movement's grievances, raised the profile of the student movement, and provided publicity for the movement's activities. The student newspapers would, as Francois Raillon put it, "became the vehicle for students who wanted to forge a new history" $(1985,70)$. In the post-1966 period, the student newspapers began to perform another function: to produce work 
by students, including investigative reporting, as well as to update on activism throughout campuses across the country (Douglas 1970, Steele 2005).

New student groups were increasingly active. One such group was Mahasiswa Menggaguat ("Students Oppose"), formed in Jakarta on January 15, 1970. It intended to pressure the government to speed up an investigation on corruption known as the Commission of Four. Mahasiswa Menggaguat is typical of the efforts of students in the post-KAMI era. Actions were built around social networks of activists, student groups, and pre-existing movement communities. Alongside these, actions also involved new efforts by students in Bandung to "Petition for Justice," a statement signed by students in the KAPI group in Bandung. The petition expressed students' mistrust of government" and called on government to be more socially responsible. This included, as some student groups demanded in Yogyakarta and Jakarta, "calls for a government-imposed ban on massage parlors and gambling dens in support of more 'socially responsible' development" (Reported in Mahasiswa Indonesia, January 21, 1970).

More problematic had been the promised electoral reforms. As Zufluki Lubis, the leader of the group Young Generation, said to about 30 students in November, 1970:

the government, the army, the political parties form a group in politics [who] do not, at all, have a modern orientation. They are not at all democratic. They are totalitarian (totaliter)....[students] are part of a new political force that is outside the political power of the army and political parties and which will only represent our interests and aspirations (Reported in Mahasiswa Indonesia, November 29, 1970).

Suharto had promised in 1967 that "the New Order would not degenerate into a military dictatorship, and that the rule of law, democratic principles and human rights would be upheld" (Bourchier and Hadiz, 2003, 12). The regime promised new elections to be scheduled within two-years when it was first inaugurated in March 1966. However, electoral - reforms were delayed pending new rules implementing changes to political parties and mass organizations. Political parties were re-shaped into three broad party-groups, and a small number of massorganizations were officially sanctioned by the government. If Indonesian politics under Sukarno had been a chaotic and sometimes seething environment, in the early years of the New Order politics was purged of all conflict, except that wielded by the state.

Officially, the 1971 election involved choices between three party groups-blocs two of political parties [one secular bloc and one Muslim bloc] and the Golkar [functional groups] party. Intellectuals feared the growing militarization of politics, concerns the new regime dismissed as "groundless" (Suharto, 1967 [2003], PAGE). The regime attempted to avoid the fragmented electoral composition of the 
Indonesian parliament by implementing new rules governing party organization (Suharto, 1967 “Interim Peoples' Representative Council” Address). The new rules forced existing political parties to consolidate. One new political party-Golongan Karya ("Functional Groups,") recruited from over 90 groups and associations, including the civil service and the military. Secular and Moslem political parties were consolidated into "blocs," supposedly consistent with the 1945 Constitution. (Besar [1968] quoted in Chalmers and Hadiz [2003,43]).

Through examination of two student dissident campaigns in the 1970s-1) the 1971 White-Group (GOLPUT) Campaign and 2) the 1978 student campaigns against national elections - these activities reveal strategic political identities students adopted during a period when expressing political opposition was extremely difficult due to strict restrictions on public groups, gatherings, and anti-government speech. At times, student dissident campaigns reflected a shifting dynamic involving the promotion of public narratives about corruption and virtue. At other times, students organized actions aimed at the new electoral reforms.

A call to boycott the 1971 election was followed by a creative and imaginative campaign called GOLPUT, or White Group (Golongan Putih), a word play on the Golkar (Functional Groups). GOLPUT grew out of a justification for student activism newly identified in the 1970s by Arief Budiman as "moral force power (Budiman 1978). Moral force power meant that "students sought only to speak their minds, to inform policy-makers of problems and injustices, and then, as in the manner of classical Javanese mythology, retreat" (Budiman, 1978, 610). Moral force power permitted a strategic critical role for student-dissent, even while perhaps rendering students essentially powerless to act.

At a meeting of GMNI (Nationalist Indonesian Student Movement) on the $25^{\text {th }}$ of November, 1970, Arief Budiman called the upcoming elections "a theatrical exercise designed to disguise rule by force," "sandiwara penguuasa untuk mempertahakan kekuasaanja." (GMNI Diskusi Kader Nasional [National Recruitment Discussion, Indonesian Nationalist Student Organization], West Java, 21-25 November, 1970). The GOLPUT campaign urged Indonesian citizens to demonstrate opposition to the election by refusing to participate. Opposition did not have to be difficult or expensive, its proponents said: "To show that someone identifies with the White Group, they will wear a white five-sided badge with a black border. They can make these badges themselves using a piece of card and a safety pin" (Golput Manifesto [1971], Bourchier and Hadiz 2003, 73-74).

The White Group called on individuals to critically evaluate the electoral reforms that had made the Indonesian people "spectators" in their own politics. The White Group, themselves, denied political ambitions. Instead, it aimed at carrying 
out "public education for the general public, especially the younger generation ... through holding discussions concerning current political issues, by openly sharing thoughts and so on." (Golput Manifesto [1971], Bourchier and Hadiz 2003, 73). Defining its identity against the values and culture of the New Order, the White Group noted:

It does not aim to make people follow any particular political stream but to encourage them to think critically and creatively in confronting their environment. ... The White Group movement in itself already constitutes political education, by implanting awareness within society that in a general election every citizen has the right not to vote (in Bourchier and Hadiz 2003, 73-4).

GOLPUT denied it was an organization,

The White Group is not an organization. It is an identity, an identity for those who are not satisfied with the present situation because the rules of democracy have been trampled upon, not just by political parties (for example, when they initiated the general election regulations) but also the Golongan Karya [Golkar] who in their endeavor to win this election utilized government agencies as well as undemocratic methods" Bourchier and Hadiz 2003, 73-4).

The adoption of an identity constructed around "a cultural movement" that did not "struggle for ... political power, but a social tradition whereby basic rights are always protected from arbitrary power" reflected the posture of "moral force" power identified by Budiman $(1978,610)$. The group was careful to identify as law-abiding and to not risk using overt tactics that could be labeled disruptive. The "White Group does not act outside the law," its organizers proclaimed, but in fact to "strengthen obedience of the law" (Golput Manifesto [1971], Bourchier and Hadiz 2003 74). As an adaptation to the repression of direct action and large mass-membership organizations, the White Group fit the contours of what was acceptable opposition-speak in the New Order. It exemplified the moral-force power idea of critique without action.

The student movement," Arief Budiman argued $(1978,616)$, was modeled on "the [Javanese concept of the] resi, the hermits and sages [who] reside in isolated caves or on lonely mountainsides, removed or withdrawn from the society. Their typical role is to diagnose decay within the kingdom and to give warning of the impending downfall of the dynasty."

Following the GOLPUT campaign, students increasingly agitated against foreign investment in Indonesia, spurred on by development projects in which Japan played a leading role. In the following parable (called the Water Buffalo parable), the student-movement is depicted in the conversation between two water-buffaloes: 
One day a large, well-fed buffalo was speaking to a thin buffalo, "Believe me when I say we are all well-fed. We are building a new nation, so just stay quiet, everything will be alright." The little one answered, "So, if ordered, I should just stay quiet? Meanwhile, our friends get thinner as the fields of grass get bigger! How can one stay quiet in a world so corrupt?" The large buffalo replied, "It won't come to that, but remember little one, don't grow horns so long that you are no longer polite and become angry." (ITB StudentCouncil Open-Letter, "Dialog between Two Water Buffaloes," 1973).

This parable referenced the regime's own discourse on development. A growing narrative of corruption framed many of the students' concerns. The reference to "long horns" was a sly reference to the criminalizing of 'long-haired' men that had recently occurred in 1973 during a period of much urban unrest in Bandung and Jakarta.

On August 9, 1973, following the worst of the riots in Bandung that resulted in the destruction of 1000 stores and 150 automobiles, one newspaper, Indonesia Raya, noted that "Bandung may have seen some of the worst of the violence because of the 'liberal attitudes' of the city's youth and because of lingering class resentments between groups of rich and poor youth" ("Let this Be a Lesson," August 9, 1973, page unknown). While students had denied any involvement in the riots and violence that swept through Bandung in August 1973, they were nonetheless singled out as instigators for the unrest. Finally, the parable could be read as a description of the interaction between older and younger activists during many student dialogues. The parable captured sentiments of bapakism (paternalism) endemic in national politics.

\section{Indigenous Power, Indigenous capital: Nationalist Themes of Student Activism in the early 1970s}

Whereas Sukarno-era policies generally insulated the Indonesian economy from direct foreign-investment and cooperative ventures, the early New Order regime reversed these policies. The 1967 Foreign Investment Act authorized tax incentives to foreign companies with contracts in three sectors: public-infrastructure, the media, and retail-distribution (Chalmers and Hadiz 2004, 15). In keeping with the regime's emphasis on state-led development, the first Five Year Plan for Development (REPELITA I) was implemented in 1969. REPELITA emphasized "the agricultural sector and the types of industry supporting it (fertilizer, machinery, and equipment)...targets what is most urgently needed by the public at large: food, clothing, improved infrastructure, people's housing, a wider field of employment, and spiritual well-being" (Suharto, 1969). Both policies were part of the general shift towards, on one hand, opening the Indonesian economy to more external influences and, on the other hand, a more rational, state-planned process of intervention in the domestic-economy. As John Bresnan noted, 
The most controversial aspect ... was not any of these general policies ... but rather the specific practices they permitted. The regime was immersed in corrupt practices in the granting of licenses, lending of funds, letting of contract, and every other form of state action that had any economic value ... many observers believed that Indonesian corruption was the most pervasive in the region (Bresnan 1993, 292).

The shift in policies toward greater foreign government investment and greater freedom by foreign investors to operate through joint-ventures was especially criticized by many student activists who were familiar with the lessons of dependent development from Latin America, as Rizal Ramli explained (Interview by author, Jakarta, June 6, 2002). Through discussion groups in the 1970s, students began to read and discuss books that referenced the experiences of newly-industrializing economies. A former student activist from Bandung told me:

We saw that Japan and Korea were the biggest models for Indonesian economic development-there wasn't much in the way of popular participation in the economy other than as labor, as participation in physical terms. Rather, decision-making was made by a small group of technocrats within the state [which] provided the basis for cronyism (Interview by author, Yusman SD, Bandung, April 1 2002).

Protesting against Japanese investment in Indonesia permitted students a new public role. Student-held protests outside the Japanese-owned President Hotel in Jakarta drew attention to an urban consumer culture constructed around the acquisition of imported Japanese goods like Suzuki motorcycles and Sony transistor radios (Bresnan 1993, Aspinall 1999). It would also be the last time that the regime would tolerate student protest. A former Student-Council Activist, Hariman Siregar, told me, "From 1974 to 1976, universities changed, Suharto banned students from organizing. Students never again experienced the university in the same way" (Interview, Jakarta, April 2002).

\section{The White Book: Student Opposition in the Late 1970s}

Student-council activism was a particular form of dissident culture that acknowledged the roles of intellect and prestige and power attached to particular types of knowledge and technical expertise. In the New Order period, students recognized that the values of intellectual inquiry could be used as tools of activism. Part of this component of their identity was shaped by the repressive context of the New Order state, which led students at the Technology Institute (Bandung, West Java) to write their own manifesto that would become known as The White Book (Heri Akmadi, interview by author, Jakarta, June 2, 2002).

The White Book reverberated with themes that had been discussed in study clubs and discussion groups since 1975. Students demanded greater political 
accountability of external actors such as foreign government lenders and banks. Students also began to insist on a greater role for local actors, rather than top-down imposed solutions that tended to emphasize 'experts' and foreign consultants. In 1977 , students began to emphasize political reform as part of their dissident writings and action. They began to openly demand open elections without intimidation and with secret balloting. Rallying around the opposition candidate Governor of Jakarta, Ali Sadikin, they issued a number of reasons why Suharto should not be reelected. These reasons included 1) the failure of the developmental strategy, 2) the corrupt practices of the regime in implementing development, 3) the failure of the government to subsidize domestic rice-producers at the expense of foreign investors and 4) the general failure of the government to improve the economic conditions of most of Indonesia's poor (The White Book, 1978, 153-154).

\section{Heri Akmadi and the ITB Student Council in the late 1970s}

Elected at the end of November 1977 as the Chairman of the ITB Student Council, Heri was Chairman at a time when, he remarked, the student body had been "asleep" (Interview, Rizal Ramli, Jakarta, June 2002). As the newly elected StudentCouncil Chairman in 1977, Heri Akmadi acknowledged the role students had historically played in politics:

"the basis of the students' political stance in their struggle...is [their] natural trait...[to] seek knowledge and strive after truth...Students are trained as a matter of course to be perpetually restless and to doubt everything, so that they can then use their mental capacities to analyze each phenomenon logically, systematically and objectively" (Akmadi 1979, 112).

Heri Akmadi saw students as uniquely positioned to challenge the exercise of power. The failure of intellectuals to actively critique, Akamdi noted, was no surprise, given the New Order:

"The Intellectuals, who are supposed to be better informed about their rights and responsibilities in society, are also affected by this climate of fear. We can detect its influence in their choice of words. Many intellectuals prefer to use veiled and sometimes confusing language to describe certain realities...They see the examples set by the many Indonesian Intellectuals who have been formerly incarcerated in prison because they openly expressed their opinions about some situation which reflected badly on the New Order" (Akmadi 1979, 143).

Student councils were frozen and replaced by new organizations that were no longer headed by students, but by Rectors' Assistants (Akmadi 1979, 71). Existing student associations such as HMI (Islamic Student Association), GMNI (Indonesian Nationalist Student Movement), PMKRI (Indonesian Catholic Student 
Association), GMKI (Indonesian Christian Student Movement), and PMI (Indonesian Muslim Student Movement) were prohibited from conducting activities on university campuses (Hadiwinata 2003, 63). The decision in 1978 to suspend campus activities and to arrest and detain the leaders of student government associations was a bitter end to the regime's initial support for the student movement. Campus Normalization in 1979 would force the student movement out of politics; it emphasized solely scientific activities and analysis for students and membership in scholarly, rather than political, organizations. This policy sought to disempower student-dissidents who had, since the 1930s functioned as public critics and contributed to public discourses. Against the constraints of normalization, students publicly stated their grievances in terms of moral opposition to abuse of power. Despite the network structure of the student movement, individual activists would play key roles in issuing public criticism. Their methods were necessarily creative, reliant on court-testimony, participation in international conferences, academic work, manifestos, and research. As Heri Akmadi summed up the situation in 1979, "there is no role in decision-making for individuals, groups or social groups outside [the state; once again the student's role is only that of an errand boy" (Akmadi, 1979, 51).

\section{Conclusion: Oppositional Politics and Dissent in the 1970s}

The student dissidence described in this work reflected both private and publicfrustrations, grievances, and intellectual concerns about the increasingly authoritarian nature of Indonesian politics. Particular modes of protest and repertoires evolved as a result. Through speeches, manifestos, declarations, and articles, activists would generally express their private and personal disillusionment with, rather than criticism of, the status quo. Student activism is not as simple as the notion of "generational anger" suggests (Feuer 1966). A long history of student participation in Indonesian politics demonstrates that activism was not fueled solely by grievances, but that it's mobilization relied on existing networks of social organizations and sponsored activities. Whether it was football-clubs, discussion groups, dormitories, or study-clubs, these activities promoted communities built on strong solidarities that could be easily converted (in the way Doug McAdam [1993] understood) into a basis for insurgency.

As representative of something broader and more significant, the student leaders in the 1960s absorbed ideals that were shared by activists of the same time outside Indonesia: of a search for meaning and authenticity by youth in a world defined by irrationality and tremendous state violence. The rise of intellectual dissidents in the Indonesian student movement marked a fundamental shift in 
a movement that for most of its early history was defined by groups (political parties, student organizations, and clubs) rather than individuals. The student movement provided an arena of socialization where individuals learnt political skills, developed tactics, and found their political voice-whether as exiles, political dissidents, or emerging leaders.

The military would redefine the Indonesian nation in 1966 as both anticommunist and post-Sukarno. As the first president of Indonesia and the leader of Indonesian independence in 1949, Sukarno had built his own myths of nationalism in the 1950s as a strategy to govern. As I have attempted to show intellectual critiques of the Sukarno years took aim at the ideological components of the policies and the often rote-recitation required to carry out basic functions (in order to graduate from university, for example). In contrast, a decade later, when political -parties and mass-organizations were blunted into mere instruments of state-sanctioned popular will, student-activists came to represent often lone-voices in the expression of individual conscience against authority, conformity, and dictatorship.

New to the 1970s was the adaptation by students to a culture and politics constructed around the myths and symbols of the military regime, the New Order. Despite its relatively small size and official attempts to limit their activism, the 1970s student movement had a large and relatively lasting impact. I regard as one of their most important aspects their ability to serve as the "critical communities" that Thomas Rochon $(1998,50)$ argued are essential to lasting and effective social activism. The student movement's most lasting impact was the way students contributed to ideas and strategies of political reform, which then became part of the Anti-Suharto movement in the 1990s. Many of their ideas did not become fully realized as broader social strategies for action in Indonesia until the 1980s and 1990 s. By then, students who were active in the 1970s were no longer politically active or had left Indonesia to finish professional degrees at universities abroad. Some, like Akmadi and Ramli returned to Indonesia in the 1990s and continued to be involved in political reform. The themes of corruption and nepotism became central to the populist reform movement, Reformasi, that swept Indonesia in the late 1990s and which, in 1998, would result in Suharto's resignation.

\section{References}

Anderson, Benedict and Ruth T. McVey, 1971. A Preliminary Analysis of the October 1, 1965 Coup in Indonesia. Ithaca, NY: Cornell University Modern Indonesia Project. 
Anderson, Benedict. 1972. Java in a Time of Revolution: Occupation and Resistance, 1944-1946. Republished. Jakarta: Equinox Publishing.

Anderson, Benedict. 1970. "In memoriam: Soe Hok-Gie." In Indonesia 9, 225-7. Ithaca, NY: Cornell University: Modern Indonesia Project.

Akmadi, Heri. 1979. Breaking the Chains of Oppression of the Indonesian People. Ithaca, NY: Cornell University: Modern Indonesia Project.

Akmadi, Heri. Interview by author. Jakarta. June 2, 2002.

Aminoedin, Augusdin. No Date. "Student Organizations in Indonesia." President of the PPMI (National Union of Indonesian students).

Anwar, Aldy. 1966. KAMI Column. Mahasiswa Indonesia.

Aspinall, Edward. 2005. Opposing Suharto: Compromise, Resistance and Regime Change in Indonesia. Stanford: Stanford University Press.

Bachtiar, Harsja W. 1967 "Indonesian Students and their Political Activities." Paper presented at the Conference on Students and Politics, San Juan: Puerto Rico. March 27-31.

Besar, Abdulkadir, ([1972] 2003) "The Family State." In Indonesian Politics and Society: A Reader, ed. David Bourchier and Vedi. R. Hadiz, 41-43. London: Routledge.

Boudreau, Vince. 2004. Resisting Dictatorship: Repression and Protest in Southeast Asia. Cambridge: Cambridge University Press.

Bourchier, David and Vedi Hadiz, eds. 2003. Indonesian Politics and Society: A Reader. London: Routledge.

Bresnan, John. 1993. Managing Indonesia. New York: Columbia University Press. Buchori, Mochtar and Abdul Malik. 2004. "The Evolution of Higher Education in Indonesia." In Asian Universities: Historical Perspectives and Contemporary Challenges, ed. Phillip Altbach and Toru Imakoshi, 249-77. Baltimore: Johns Hopkins University Press.

Budiman, Arief. 1978 “The Student Movement in Indonesia: A Study of the Relationship between Culture and Structure." Asian Survey 18 (6): 609-625.

Budiman, Arief. 1970. "Diskusi Kader National." [National Recruitment Discussion.] Gerakan Mahasiswa Nasional Indonesia (GMNI), West Java, 21-25 November 1970. Photocopy of original.

Budiarso, Edy. 2002. Menentang Tirani: Aksi Mahasiswa '77/'78 (Standing up to Tyranny: Student Activism '77/'78). Jakarta: PT Grasindo.

Cahyono, Indro. Interview by author Jakarta. June 2002.

Cahyono Indro. 2002. "Memehami Gerakan Mahasiswa '77/'78” ("Reflections on the 1977/1978 Student Movement") In Menentang Tirani: Aksi Mahasiswa 
'77/'78 (Standing up to Tyranny: Student Activism 1977/1978), xv-xxiv. Jakarta: PT Grasindo.

Chalmers Ian and Vedi Hadiz, eds. 1997. The Politics of Economic Development in Indonesia. New York and London: Routledge.

Cohen, Matthew Isaac. 1999. "Timely Art: An Interview with the Poet Rendra." Inside Indonesia 19 (22): 3.

Crouch, Harold. 1978. The Army and Politics in Indonesia. Jakarta: Equinox Edition.

Douglas, Stephen A. 1970. Political Socialization and Student Activism in Indonesia. Urbana: University of Illinois Press.

Emmerson, Donald. 1987. "Students and the Establishment in Indonesia: The Status-Generation Gap." In Population, Politics and the Future of Southeast Asia, ed. Donald H. Wriggins and James F. Guyot, 259-95. New York: Columbia University Press.

Feith, Herbert. 1962 [2007 reprint]. The Decline of Constitutional Democracy. Originally published by Ithaca, NY: Cornell University Press. Reprint. Jakarta, Indonesia: Equinox.

Feuer, Lewis. 1969. The Conflict of the Generations: The Character and Significance of Student Movements. New York: Basic Books.

Hadawinata, Bob S. 2003. The Politics of NGOs in Indonesia: Developing Democracy and Managing a Movement. London: Routledge Curzon.

Hatta, Mohammad. 1981. Indonesian Patriot: Memoirs. Ed. C.L.M. Penders. Singapore: Gunung Agung.

Golput (The White Group). The GOLPUT Manifesto [1971]. Reprinted in Bourchier, David and Vedi Hadiz, eds. 2003. Indonesian Politics and Society: A Reader. 73-74. London: Routledge.

Indonesia Raya, "Jadikan Bahan Peladjaran," ("Let this be a Lesson”). August 27, 1973. CSIS Library, Jakarta.

ITB Student-Council. 1973 [1974] "Open-Letter: Dialog between Two Water Buffaloes." Reprinted in Marzuki Arifin, Peristiwa 1973-1974 (Events of 19731974). Jakarta: Publishing House Indonesia, Inc.

ITB Student Council. 1978. “White Book of the 1978 Students' Struggle.” Reprinted in Indonesia, Volume 25 (April 1978) 151-182. Ithaca: NY: Cornell University Modern Indonesia Project.

Johnston, Hank. 2005 "Talking the Walk: Speech Acts and Resistance in Authoritarian Regimes." Repression and Mobilization, ed. Christian Davenport, Hank Johnston and Carol Mueller, 108-37. Minneapolis: University of Minnesota Press. 
Klandermans, Bert. 1992. "The Social Construction of Protest and Multiorganizational Fields." In Frontiers in Social Movement Theory, ed. Aldon D. Morris and Carol McClurg Mueller, 77-103. New Haven: Yale University Press.

Legge, J.D. 1997. Sukarno: A Political Biography. Singapore: Archipelago Press.

McVey, Ruth. 1990. “Teaching Modernity: The PKI as an Educational Institution.” Indonesia 50: 5-28.

Maxwell, John. 2001. Soe Hok-Gie. Pergulatan Intelektual Muda Melawan Tirani [Soe Hok-Gie: The Views of a Young Intellectual Opposed to Tyranny] Jakarta: PT Utama Grafiti.

Mochtar, Hasyrul. 1998. Mereka Dari Bandung: Pergerakan Mahasiswa Bandung, 1960-1967 [They From Bandung: Views on the Bandung Student Movement, 1960-1967] Bandung, Indonesia: Penerbit Alum.

Murray, R. Thomas. 1973. A Chronicle of Indonesian Higher Education. Singapore: Chopmen.

Paget, Roger. 1970. Youth and the Wane of Sukarno's Government. Unpublished Dissertation Thesis, Cornell University.

Polletta, Francesca. 2006. It Was like a Fever: Story Telling, Protest and Politics. Chicago: University of Chicago Press.

Raillon, Francois. 1985. Les Etudiantes Indonesiennes et L'ordre Nouveau: Politique et Ideologie de Mahasiswa Indonesia, 1966-1974 [Indonesian Students and the New Order: The Politics and Ideology of the Newspaper Indonesian Students, 1966-1974] Paris: Edition de la Maison des sciences et l'homme.

Ramage, Douglas. 1995. Politics in Indonesia: Democracy, Islam and the Ideology of Tolerance. London: and New York: Routledge.

Ramli, H.M. Yusuf, ed. 1997.50 Tahun HMI Mengabdi Republik. Jakarta: Indonesia PT Putrapanca Hawa.

Ramli, Rizal. Interview by author Jakarta. June 6, 2002.

Ricklefs, M.C. 1993. A History of Modern Indonesia since c. 1300. $2^{\text {nd }}$ ed. Stanford: Stanford University Press.

Regulation on Higher Education, 1961. Ministry of Education, Republic of Indonesia.

Rochon, Thomas. 1988. Culture Moves: Ideas, Activism and Changing Values. Princeton: Princeton University Press.

Salim, Emil. 1954. "Report of the Student Council at the University of Indonesia on the Living Conditions of Students in Jakarta." Hand-written mimeograph.

Siregar, Hariman. Interview by author. Jakarta. May 15, 2002.

Smith, Theodore M. and Harold F. Carpenter, 1974. "Indonesia University Students and their Career Aspirations." Asian Survey September 14 (9): 807-826. 
Soe, Hok-Gie. 1966 [2005] Catatan Seorang Demonstran (Demonstration Writings). $8^{\text {th }}$ ed. Jakarta: LP3ES. Reprint of Soe Hok-Gie's diary originally written in 1966.

Steele, Janet. 2005. Wars Within: The Story of Tempo, an Independent Magazine in Soeharto's Indonesia. Jakarta: Equinox.

Suharto, 1969. REPELITA I speech. Jakarta: Indonesia. Ministry of Information.

Suharto. 1967. Further Policies of the Ampera Cabinet after the Special Session of the Provincial People's Consultative Assembly." August 16. Republic of Indonesia: Ministry of Information.

Suharto, 1973. End of Year Address. Reprinted in Chalmers and Hadiz (1997) eds. The Politics of Economic Development in Indonesia.

Sukarno. 1965. An Autobiography as Told to Cindy Adams. New York: BobbsMerrill Company Inc.

Taylor, Verta and Nancy E. Whittier, 1992. "Collective Identity in Social Movement Communities: Lesbian Feminist Mobilization." In Frontiers in Social Movement Theory, ed. Aldon D. Morris and Carol McClurg Mueller, 104-29. New Haven: Yale University Press.

Taylor, Verta and Nella Van Dyke, 2004. “'Get up, Stand up': Tactical Repertoires of Social Movements." In The Blackwell Companion to Social Movements, ed. David A. Snow, Sarah A. Soule and Hanspeter Kriesi, 262-93. Oxford, UK: Wiley-Blackwell.

Yusman, S.D. Interview by author, Bandung. April 2, 2002. 



\author{
Janina Gosseye \& John Macarthur
}

\title{
Angry Young Architects: Counterculture and the Critique of Modernism in Brisbane, 1967-1972
}

\begin{abstract}
By 1967, Brisbane architecture students had had enough. Disenchantment with their "outdated" architectural education and the rigidity of the Australian architectural establishment opened out onto the wider context of the Moratorium opposing the Vietnam War and the reactionary Queensland Government of Johannes Bjelke-Petersen. This chapter describes how between 1967 and 1972, through a series of organized "events," this generation of Brisbane architects began a critique of architecture's modernist orthodoxy as an intrinsic part of a wider reaction to global events and politics of the State of Queensland.
\end{abstract}

One of the largest protest marches in Queensland's history took place on September $8^{\text {th }}, 1967$, when students marched some five kilometers from the University of Queensland (UQ) to Brisbane's city center, demanding an end to conscription for the Vietnam War and wider civil liberties (Ferrier and Mansell 2004, 266-272). The protest was marshalled alphabetically by faculty, and then by year cohorts. This meant that the Architecture faculty was in front and the first year students at the head of the line. As a result, when protesters met a wall of police in the city center, almost the entire architecture student body was arrested. Paul Memmott, then a first year architecture student at UQ recalls: “... in our first year ... 5000 people ... marched into the city ... and the police watched us the whole way and we all got into Roma Street and the police had paddy wagons on both sides of the road and they attacked everybody and arrested as many people as they could" (Memmott 2013; Ferrier and Mansell 2004, 270). ${ }^{1}$ For many, their radicalization

1 In Radical Brisbane. An Unruly History, Ferrier and Mansell (2004) describe this event as follows: "SDA [Students for Democratic Action] led 4000 students and staff membersapproximately half the campus population-onto the road towards the metropolis. More supporters, les intrepid, marched alongside on the footpath. At the corner of Makerston and Roma streets, they were confronted by 250 police and ordered to disperse. About 1500 to 2000 sat down outside the present police headquarters. Police moved in and began making arrests, 114 in total." 
began on that day. This march was also the first of a series of intersections between architecture student culture and the conservative government of post-war Queensland.

Although an early settlement of the British in Australia, Queensland developed more slowly than other Australian states. Well into the early twentieth century, Queensland was a largely agricultural economy marked by brutal frontier warfare with the Aboriginal nations of the area and spectacular short-lived gold rushes. After a banking crisis in the depression of 1890 Brisbane, the capital of Queensland lost much its financial independence to the southern capitals of Sydney and Melbourne. A dispersed and highly independent workforce of miners and agricultural workers led to the early rise of socialist politics, the world's first Labor party government (for one week) in 1899, and a popular pacifist and anti-conscription movement in 1917. Throughout the twentieth century, progressive and then conservative governments practiced a statist agrarian socialism that did not favor education or culture (Evans 2007). Compulsory education ended at age fourteen until 1964, and the first university, the University of Queensland, was only established in 1909, half a century after Sydney and Melbourne inaugurated theirs (Goad 2012; Queensland Government 2014). As an urban area, Brisbane was relatively underdeveloped and characterized by a local residential type of elevated, timber, detached houses and grand classical government buildings from before the bust of 1890 (Fisher and Crozier 1994). By the mid-twentieth century, Sydney and Melbourne had become cosmopolitan cities with a restaurant and café culture and an interest in modernist art and architecture, and while there were elements of a progressive culture in Brisbane, its image remained that of a large country town living in the shadow of its attempts to become a city in the late nineteenth century. From the 1960s, tourism, mining, and then a sun-belt migration pattern began to propel the State towards its present prosperity. This rapid modernization of the economy, with its demand for natural resources and rapacious and largely unplanned or corrupt development of city buildings and beach resorts, reinforced Queensland's image as a place in which culture was not valued.

In 1957, a center-right coalition took government. Ten years later, in 1968, power within the coalition shifted to the more conservative National Party, led by Johannes Bjelke-Petersen-the highly conservative New Zealand-born son of a Danish Lutheran pastor. Over the next two decades, under Johannes BjelkePetersen's Premiership, Queensland became a police state in which democratic principles were trammeled to privilege the interests of a select and powerful minority; the electorate routinely manipulated; the media co-opted; parliamentary due process severely eroded; freedom of expression sacrificed to oppressive censorship; minority rights branded a risible intrusion; and civil liberties derided 
as the dangerous ploy of extremists (Evans 2007, 219-248). ${ }^{2}$ At the end of the 1960 s, as the tectonic plates of the western socio-political landscape began to shift towards socially progressive causes, Queensland's Government took the opposite direction. Paul Memmott recollects: "We didn't have a right to demonstrate, didn't have a right to carry a placard [and] at one point he [Bjelke-Petersen] brought in a law saying [that] more than three people in a public space talking about politics was illegal" (Memmott 2013). Richard Lambourne, a classmate of Memmott recalls, "after three years of studying architecture and a little bit of political dissent, I woke up one morning at six 'o clock to find sixteen policemen in my house and decided [that] perhaps it was a good time to leave Queensland... It was the days of Joh Bjelke-Petersen and they were being extremely zealous, over-zealous perhaps...I suspect that one of my housemates had been out picking magic mushrooms" (Lambourne 2013).

Social historian Raymond Evans nonetheless maintains that Bjelke-Petersen's oppressive totalitarian rule ultimately had a silver lining. By bitter experience, he writes, the totalitarian experience "taught Queenslanders ... what democratic principles, such as the separation of powers, majority rule, an objective media, an accountable government, a non-politicized public service, an uncorrupted police or judiciary, and respect for freedom of speech, minority justice and basic civil rights really meant" (Evans 2007, 221). The extreme conservatism maintained by Bjelke-Petersen's regime deepened the radical spirit in the state and transformed the University of Queensland into a focal point of socio-political dissent (Schultz 2008). Here, under the watchful eye of student leaders Brian Laver and Dan O'Neill, a New Left emerged, which was characterized by a concern with culture as well as with the staples of the Old Left politics-demonstrations, engagement in the class struggle in economic arenas, and campaigns around political issues. Influenced by the contemporary contest of public spaces in Europe and the United States as well as by groups such as the Situationist International, who strongly believed in the subversive power of the arts, and by Régis Debray's "foco" concept, Brisbane's emerging New Left set up its own cultural revolutionary encampment in the city's Trades Hall. Between March 1968 and February 1969, radical youth would gather there every Sunday night and organize a range of activities-large format discos with live music, poetry readings, folk singing, film and left wing documentary screenings (Evans 2004). This New Left spirit appealed to many (aspiring) young architects who increasingly rejected Queensland's oppressive

2 Bjelke-Petersen's regime fell in 1987 after an inquiry revealed endemic corruption, extending up to the Police Commissioner and cabinet. 
state politics and an architectural training and establishment they viewed as outdated and conformist.

Those who wanted to study architecture in Queensland had two options. The Queensland Institute of Technology (QIT, formerly known as the Central Technical College or CTC) had been offering evening courses in architecture since the early 1920s as an extension of the articled system of training. In 1937, the University of Queensland introduced an academic full-time course in architecture. Robert Cummings became the university's first lecturer in architecture and-along with his partner in practice, Bruce Lucas, the Austrian émigré architect Karl Langer, and Charles Fulton at the CTC-introduced modern architecture to Queensland. Initially UQ offered courses in Building Construction and History of Architecture and in 1939 added Materials and Testing, Freehand Drawing, Advanced Building and Construction, and Specification to the curriculum (Sinnamon \& Keniger 1987, 6). ${ }^{3}$ From the onset, Cummings taught the History of Architecture. According to former student of architecture Rex Addison, who studied under Cummings, "he had ... a penchant for a softer form of modernism...Dudok was his pin up boy" (Addison 2013). Cummings indeed placed the architecture of pre-War Dutch architect Willem Marinus Dudok as the final development of an architectural truth first revealed to the ancient Egyptians. In his lectures he religiously followed Banister Fletcher's A History of Architecture, which he-according to his son Malcolm Cummings who studied architecture at UQ from 1954 to 1960 - treated as "the bible" (Cummings 2012). In the 1960s, Cummings and his colleagues continued to promote a canon of architecture that they held to have been completed by their generation, but by then the architectural landscape had changed. The modernist dogmas of "form follows function" and existenzminima no longer corresponded to the needs of the mid-twentieth century society, and the elusive character of the era instilled a sentiment of anxiety in architects who were more interested in the iconoclastic and avant-garde actions of modernist architects than in their buildings (Williams-Goldhagen and Legault 2000, 13-22). For a generation of students fascinated by Archigram's Plug-in City ${ }^{4}$ and Buckminster Fuller's Geodesic

3 By 1940 the course was being revised, and offerings included: Architectural Drawing and Design, Descriptive Geometry, Specifications, Town Planning and Street Architecture, Surveying, Professional Practice, History of Art, History of Architecture, Architectural Drawing, Freehand Drawing, Building Construction and Materials Testing.

4 Archigram was an avant-garde architectural group, which was formed at the Architectural Association in London in the 1960s. During the 1960s, the group gained prominence thanks to its neo-futuristic, anti-heroic and pro-consumerist hypothetical (largely dystopian or utopian) designs, which expressed the desire to-through 
Domes, ${ }^{5}$ the stereometric masonry forms of Lucas and Cummings' and Langer's buildings looked heavy and out of date (Riddel October 2012). Like cats on hot bricks, post-war architects veered off in different directions, challenging what their predecessors had accepted as given and exploring the limits of the conceivable, their actions drawing on issues and concerns emerging directly out of the social, cultural, economic, and political changes of the post-war years. In Brisbane, these ruptures that were unfolding in architectural ideology met a climate of generalized dissent, which-aggravated by the complacency of the local professional architectural community-encouraged many young architects to express their discontent (Musgrave 2013). ${ }^{6}$ Through theatrical performances, films, art exhibitions, and performance art events, they questioned their architectural education and sought to subvert the tenets of modernism while satirizing their socio-political environment and challenging the authority of their peers and ultimately the State.

\section{Clash of the Conferences}

The first time that the generation gap and the ideological differences that underlay it became starkly apparent was in May 1967, when the Australian Architecture Students Conference and the Royal Australian Institute of Architects (RAIA) conference were both held in Brisbane (Cross-Section 1967). At the Institute conference, Professor Cummings and the principals of Queensland architecture firms hosted their interstate peers in dinner jackets and ceremonial chains of office. The official opening took place in the Legislative Council Chambers of Parliament House on Monday, May $29^{\text {th }}$, and was followed by a Presidential Reception at Lennon's Hotel. The following day, invited speakers Paul Ritter, town planner of

technology-create a new reality. Their projects often included elements of pop-culture and science-fiction. The main members of the group were Peter Cook, Warren Chalk, Ron Herron, Dennis Crompton, Michael Webb, David Greene and Theo Crosby.

5 Buckminster Fuller had been experimenting with Geodesic Domes for some twenty years before he designed the Montréal Biosphère for the World Expo in 1967. In 1966, Fuller was one of the speakers at the Australian Architecture Students Conference in Perth, which was attended by several architecture students from Queensland. At this conference, he emphasized that the measure of a good building was its weight (the lighter the better) and also spoke about the design of geodesic domes.

6 This discontent was not only felt among students, but also among the younger lecturers who joined the older generation at UQ and QIT. Some produced little pamphlets and handed them out to students of architecture at the University of Queensland and the Queensland Institute of Technology. These pamphlets were intended to fuel student activism. 
the city of Perth, and Graham de Gruchy, lecturer at the School of Architecture at $\mathrm{UQ}$, reflected on the architect's role in society. On Wednesday the speakers-all practicing architects and engineers-addressed the theme "Architect and building industry," bringing the conference back "down to earth" as the first speaker, Emery Balint, suggested: "I had the opportunity of listening in to your session yesterday and this made me very conscious of a division in the ranks. There are the theorists... who feel that the profession should have an image perhaps more than an ideal... and then there are the down-to-earth practitioners, the architects who feel very acutely the day to day problems and pressures of the practice of their profession" (Balint 1967, 629). On Wednesday evening, delegates returned to Lennon's Hotel for the award ceremony and the conference ended on Thursday with an "Introspection" session, reflecting on the ethics of the architectural profession. As can be derived from the proceedings, which were published in Architecture in Australia, the event was very formal in nature and aimed predominantly at networking (16 ${ }^{\text {th }}$ Australian Architectural Convention, Brisbane 1967). It was very different from the student conference, which was set up as a seditious response to the Institute conference and was announced with an image of Ron Herron's 1964 design for a "Walking City," a figure stalking across a ruined world in the aftermath of a nuclear war. " Like Archigram, the students intended to "inject noise into the system."

The conference, which preceded the RAIA conference, ran for a week, from May $20^{\text {th }}$ to May $27^{\text {th }}$, and offered not only lectures and discussions, but also work sessions, exhibitions, and site visits. For the event, the students invited (among others) the aging Giò Ponti, editor of the famous Italian architecture- and design

7 The conference was announced in 1966 in the fourth issue of the student magazine ASM. Between May 1965 and May 1966, three issues of Scarab appeared. These three issues were edited by architecture students Haig Beck, Mike Hughes, Bob Martin, Phil McMaster, Barrie Reuter and Robert Riddel. Mid 1966, architecture students Haig Beck, Tom McKerrell and Don Cunnington took over the publication and renamed it $A S M$, which stood for 'Architecture Student Magazine'. Seven issues of ASM appeared between 1967 and 1968. The fourth issue, published in early 1967, announced the National Architecture Student conference, introducing all of the speakers who had been invited, accompanied by a biography for each of them, while the fifth issue-which appeared shortly after the conference-offered a retrospective of the event. By 1970, the magazine changed name once more and became $M K 2$, of which four issues appeared between May 1970 and March 1971. 
magazine Domus, and the young avant-gardist Tony Gwilliam from the Architectural Association School of Architecture (AA School) in London-two essentially antagonistic speakers. ${ }^{8}$ While Ponti pontificated about what constituted good architecture, addressing issues such as form, structure and the profession's relation to art, Gwilliam launched a plea to talk about "building" rather than "architecture," advocating the need for new building materials and new building methods to satisfy the increasing demand for human shelter. "In one generation," he said, "we have to build what it has taken 10 generations in the past to build...We simply cannot let millions of people go without shelter" (Building Ideas with Plastics 1967). In the work-session that followed, he invited students to "create some sort of instant environment with various materials," following which several plastic and cardboard domes were constructed across the UQ campus (Gwilliam 1967). At a micro-scale, Ponti and Gwilliam epitomized the contemporary state of architectural culture: Ponti, the institutionalization of the modernist idiom and Gwilliam an apostle of the phase of experimentation, ringing in the advent of post-modernism. ${ }^{9}$

8 Giò Ponti was born in Milan (Italy) in 1891. When he attended the Australian Architecture Student Convention in Brisbane in 1967, he was 76 years of age, while Tony Gwilliam was in his mid-thirties.

9 Ponti was one of Italy's most renowned modernists. Even though he was not a member of the Congrès International d'Architecture Moderne (CIAM), which was responsible for a series of events and congresses arranged across Europe between the late 1920s and the late 1950s by the most prominent architects of the time, with the objective of spreading the principles of the Modern Movement, Ponti's ideas were in line with those of this organization. He strongly believed that architecture (and design in general) should strive for a harmonious relationship between a form and its function. By the 1960s, however, a new set of values for modern architecture emerged which went beyond looking at biological concerns and became more focused on psychological needs. These ideas were propagated by a group of CIAM's younger members, who became known as Team 10. In the 1950s this group started formulating theoretical positions that questioned the tenets of modernism and undermined the very foundations of the organization, which eventually led to CIAM's dissolution in 1959. Although Team 10 was only a small group of "angry young architects," their critical stance towards modernism was representative of a broader cultural critique of Modernism that gradually developed in post-war society, leading to architectural critic Charles Jencks eventually announcing the death of modernism in the early 1970s. 


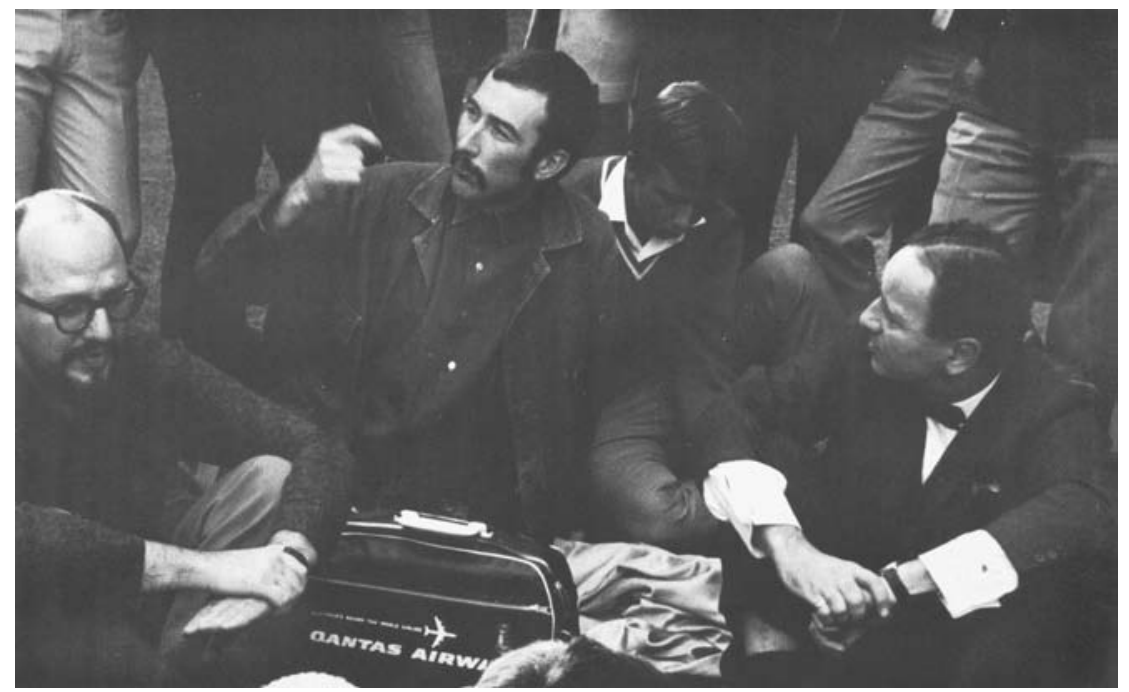

Tony Gwilliam (center) talking to architecture students during the National Architecture Students Conference held in Brisbane in May 1967. Also shown in the photograph are two of the other conference speakers, namely Harry Seidler (right) and Gilbert Herbert (left).

Photograph: Derek Ellis.

Discussions during the conference were held in a very informal manner, with both students and speakers sitting on the ground, while the evenings were enlivened with barbeques and casual parties. On Thursday night, the students organized a "happening" at the Rialto Theatre, entitled Dorcus French-A Naughty Review. Planned as a performance art event, a number of activities took place simultaneously; a rock band was playing in one corner of the room, someone was demolishing a car in another and a striptease was enacted. Proceedings however ended abruptly when-in an attempt to shock the audience-some students jumped up on stage, "armed" with a number of chickens and killed them by swinging the animals around in the air. Many of those present, among them Gio Ponti, left in disgust and the event came to an end (Tyrell and Twidale 2013).

\section{High on a Hot Banana}

The happening at the Rialto Theatre fed a nascent tradition of architecture student revues that had been initiated two years earlier. In 1965, the architecture students at UQ — under the direction of William Yang (then known as Willy Young)—took over the production of the annual revue from the Arts and Law students. These 
"Archi Revues" as they became known, were developed by architecture students of UQ and QIT conjointly and consisted of sketches, music, and experimental theatre satirizing not only architecture and urban planning but also politics and current affairs. ${ }^{10}$ Between 1965 and 1970, six reviews were held in the Avalon Theatre; OWO in 1965, RINTHF'TANG Son of OWO in 1966, High on a Hot Banana in 1967-this was the first revue to receive musical contributions from the newly minted Architecture Revue Band-Young Robert Zimmerman in 1968, Classical Stuff in 1969, and Awopbopaloobopalopbamboom in 1970. That year, Yang graduated and moved to Sydney, leaving his protégés to carry on the productions, which subsequently relocated to the new Schonell Theatre on the UQ Campus.

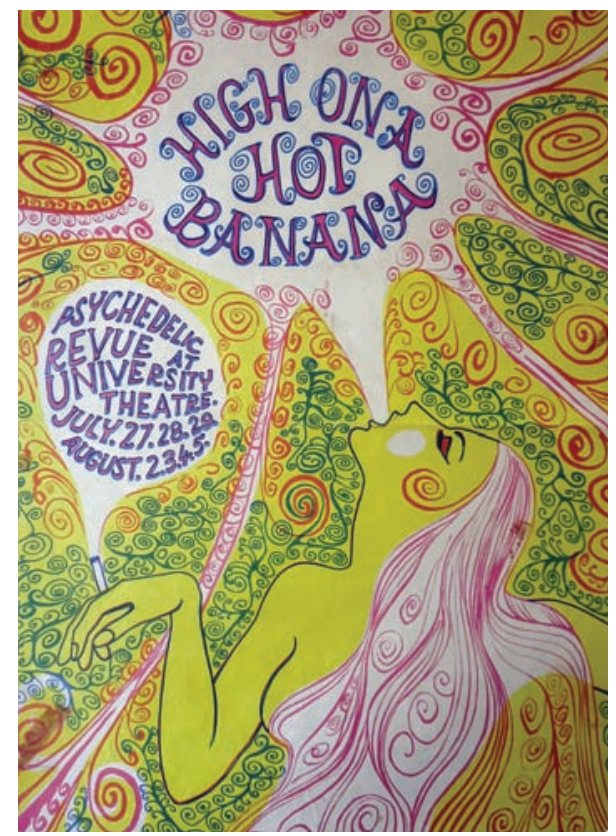

Psychedelic poster announcing the 1967 Archi Revue High on a Hot Banana.

Private collection of Neville Twidale.

According to Jack Kershaw, who was a fifth year architecture student at UQ when the first show took place, there was initially a bit of conservatism about the revues.

10 William Yang is today a well-known writer and visual and performance artist based in Sydney. 
The subtitle "New, not too blue OWO revue," he says, hinted at its more subdued character-"not too blue" meaning "not too risqué" (Kershaw 2013). Ralph Tyrell, who was a first-year student in 1965 and became heavily involved in the organization of the following revues, however claims that the show evolved and became more provocative over the years:

There was a lot of iconoclastic behaviour and there was a lot of raw bawdy stuff. But, it was clever... Nobody would have gone to a bloody review run by the communists, you know, some sort of dialectic, proselytising [event]. The architects managed to get this fine-tuned balance of maybe being irreverent [and] politically relevant (Tyrell and Twidale 2013).

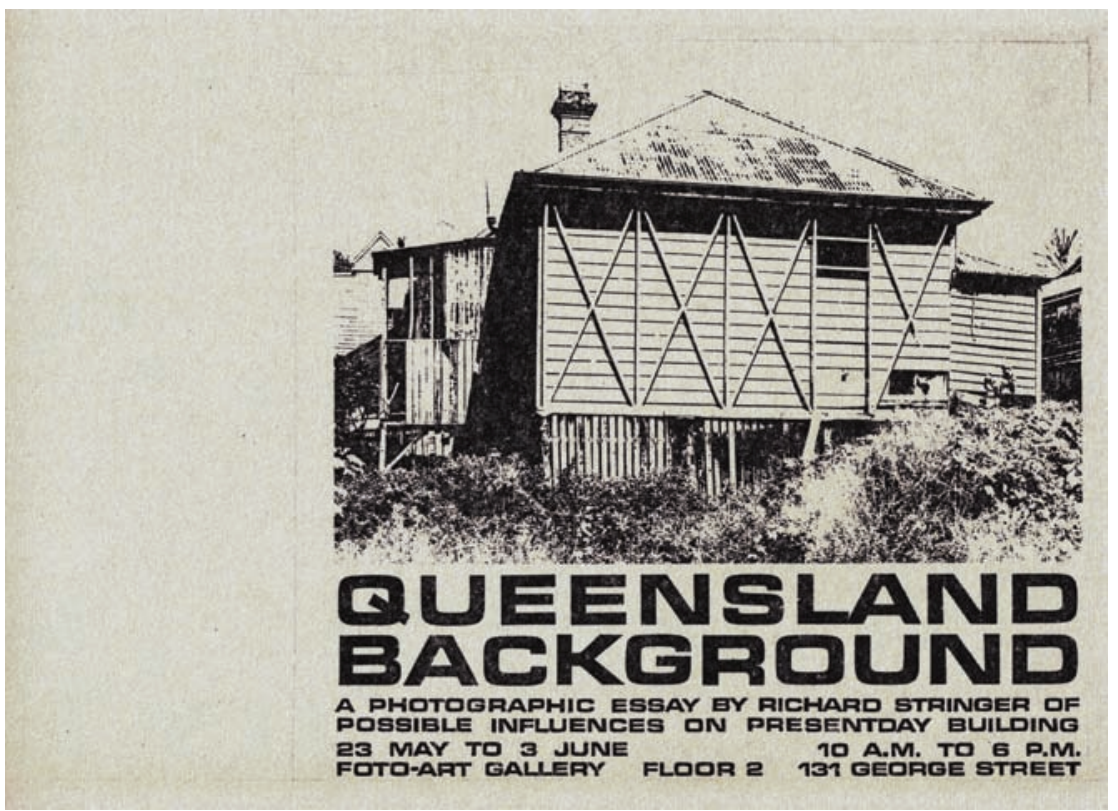

Poster announcing the photographic exhibition Queensland Background, organised by Richard Stinger in 1967.

Reproduced from ASM 5 (1967)

This shift toward the provocative was undoubtedly influenced by a changing atmosphere-globally as well as locally ${ }^{11}$. The 1968 revue, for instance, started with a "Testimony of the March," referring to the September 1967 protest where

11 In March 1966, the Government announced that National Servicemen would be sent to Vietnam. 
many of the cast had been arrested, and comprised an act entitled "The Soldier," subtitled "Thou Shalt Take What Not Belongs To You." 12

The Archi Revues also played a significant role in the development of live theatre in Queensland. In 1969 Bjelke-Petersen extended his censorship campaign from written publication into the theatre, which implied that people could be prosecuted not only for written prose, but also for on-stage utterances. The musical Hair, famous for its nude scenes, was banned in Brisbane after cabinet member Russ Hinze condemned the musical as being appealing to only the "sexually-depraved, or a group of homosexuals, lesbians, wifeswappers and spivs," and in April 1969, Brisbane actor Norman Staines was arrested by police, charged with having used an obscene expression during a performance of the play Norm and Ahmed presented by the Twelfth Night Theatre Company (Fitzgerald 1984). The Archi Revues thus not only offered talented aspiring architects a creative outlet, but also allowed them to-in an entertaining mannerchastise the oppressive socio-political environment in which they found themselves.

\section{Queensland Background}

Taking place in Brisbane in the same year as the RAIA and the Australian Architecture Student conference was a small photography exhibition organized by Richard Stringer, a young architecture graduate from Melbourne who had moved to Brisbane only four years earlier, in 1963. Upon his arrival, he was "struck [by] the silent buildings around from previous generations of architects," which inspired him to start travelling around the state, visiting mining towns, such as Ravenswood and Charters Towers, armed with his five by four inch Linhof camera (Stringer 2012).

12 The program of the Archi Revues was commonly announced on the verso of the posters. The posters are held in the private collection of Neville Twidale. 


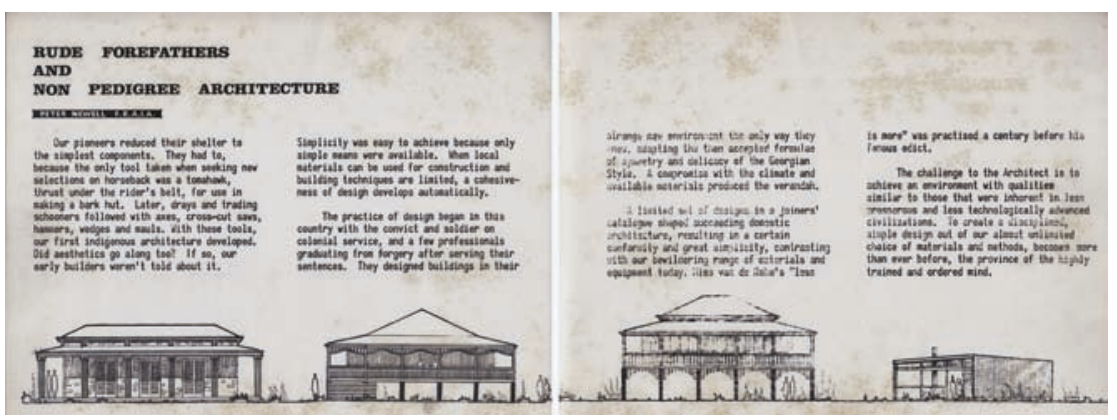

Peter Newell's essay, "Rude Forefathers and Non Pedigree Architecture" in Scarab was accompanied by several small drawings that were meant to show Queensland's architecture's "rude forefathers," which were generally thought of as "non pedigree architecture."

Reproduced from Scarab 1 (1965)

By 1967, Stringer had already developed a substantial collection of photographs of Queensland's "silent buildings," which led him to a belief that current architects were not matching up to the standard the past had set. When the RAIA conference came up, he decided to organize a photographic exhibition, entitled Queensland Background, to make visible "another side of Queensland, besides the side that the Institute [was] presenting" (Stringer 2012). This exhibition was held in Sutton House, a small, private gallery located in George Street, and consisted of sixty black-and-white photographs, each 16 inch ( 40 centimeters) high by 20 inch (50 centimeters) wide. The poster that he designed for the exhibition was indicative of what the show presented. It contained a photograph of a traditional Queensland house, constructed on stumps, with single-skin timber walls (the structure on the outside) and a pitched tin roof. According to Stringer, this is not what most people viewed as an exemplary piece of Queensland architecture. To him, however, it represented the grassroots of Queensland's building tradition. The exhibition, Stringer hoped, would offer local architects "a little eloquent testament to the environment that they were operating in" and potentially (positively) influence their appreciation of Queensland's forgotten built heritage (Stringer 2012).

In a way, Stringer's exhibition was Queensland's architecture salon des refusés. In early post-war years-driven by a desire to keep up with centers such as Sydney and Melbourne-Brisbane architects adopted an international-style modernism and (almost unanimously) discarded the local "timber and tin" building tradition that their predecessors had refined for over a century. Sleek office towers and low-lying, flat-roofed California-modern-inspired dwellings 
grew popular as the house on stilts, wrapped in a spacious veranda, accrued criticism (Taylor 1986, 116-140). A group of Brisbane's architecture students and young lecturers at the UQ School of Architecture were also concerned by these developments. In 1965, two years prior to Stringer's exhibition, the Queensland Architectural Student Association launched a magazine called Scarab, of which three issues appeared between May 1965 and May $1966 .{ }^{13}$ The first two articles of the inaugural issue, "Rude Forefathers and Non-Pedigree Architecture" and "The Influence of the $19^{\text {th }}$ Century Vernacular Tradition on Contemporary Queensland Architecture," both launched a plea for a simple architecture that drew on vernacular building traditions. Bill Carr, author of the latter essay-and then one of the young lecturers at UQ-painted a rather negative picture of architecture practice in post-war Queensland. "On thinking over the subject," he wrote:

I have been forced to conclude that the guts of this [vernacular building] tradition has had no influence on $20^{\text {th }}$ century Queensland architecture...The economy, the structural integrity, the pre-fabrication [and] the lack of pretention of the $19^{\text {th }}$ century Queensland building vernacular have all been overlooked. These very qualities which would seem to be so important to our own picture of the $20^{\text {th }}$ century have evaded us (Carr 1965).

Peter Newell, author of the opening text equally concluded that " $t \mathrm{t}]$ he challenge to the [contemporary] architect is to achieve an environment with qualities similar to those that were inherent in less prosperous and less technologically advanced civilizations" (Newell 1965).

Both essays appear to have been informed by the writings of Bernard Rudofsky and Steen Eiler Rasmussen. In Rudofsky's 1964 publication Architecture without Architects: A Short Introduction to Non-pedigreed Architecture, he introduced the concept of "communal architecture," produced not by specialists but by the spontaneous and continuing activity of a community. Rudofsky pointed to the practical knowledge of the untutored builder as an untapped source of inspiration for the industrial man trapped in chaotic cities (Rudofsky 1964). Five years prior to Rudofsky's publication, Rasmussen proffered a similar suggestion in his book Experiencing Architecture. ${ }^{14}$ Here, he (famously) wrote:

At one time the entire community took part in forming the dwellings and implements they used...[H] ouses were built with a natural feeling for place, materials and use... Today, in our highly civilized society, the houses which ordinary people are doomed to live in and

13 See footnote 7.

14 Rasmussen was a lecturer at the Royal Danish Academy of Fine Art. One of this students was Jørn Utzon, who later designed the Sydney Opera House (1973). 
gaze upon are on the whole without quality. We cannot, however, go back to the old method of personally supervised handicrafts. We must strive to advance by arousing interest in and understanding of the work the architect does (Rasmussen 1959, preface).

Similar ideas also surfaced in the later issues of Scarab. Robert Riddel, one of the editors of the journal and at the time an architecture student at QIT, authored the opening essay of the August 1965 issue. He entitled his contribution, which sharply criticized the local architecture establishment, "Resurrection." Riddel wrote "the architect in Aust [sic.] has with few exceptions become nothing more than a shadow of intellect by being a mere draftsman catering passively to the most absurd whims of an unfortunate clientele." Riddel subsequently derided early twentieth century functionalist housing as "unimaginative" and launched a plea to develop a different type of architecture that is both psychologically pleasing and economically viable. To demonstrate his point, the article is accompanied by a photo of simple timber barn that he described as "the epitome of ingenuity... [that] shows what can be done with second-hand materials and thought" (Riddel 1965).

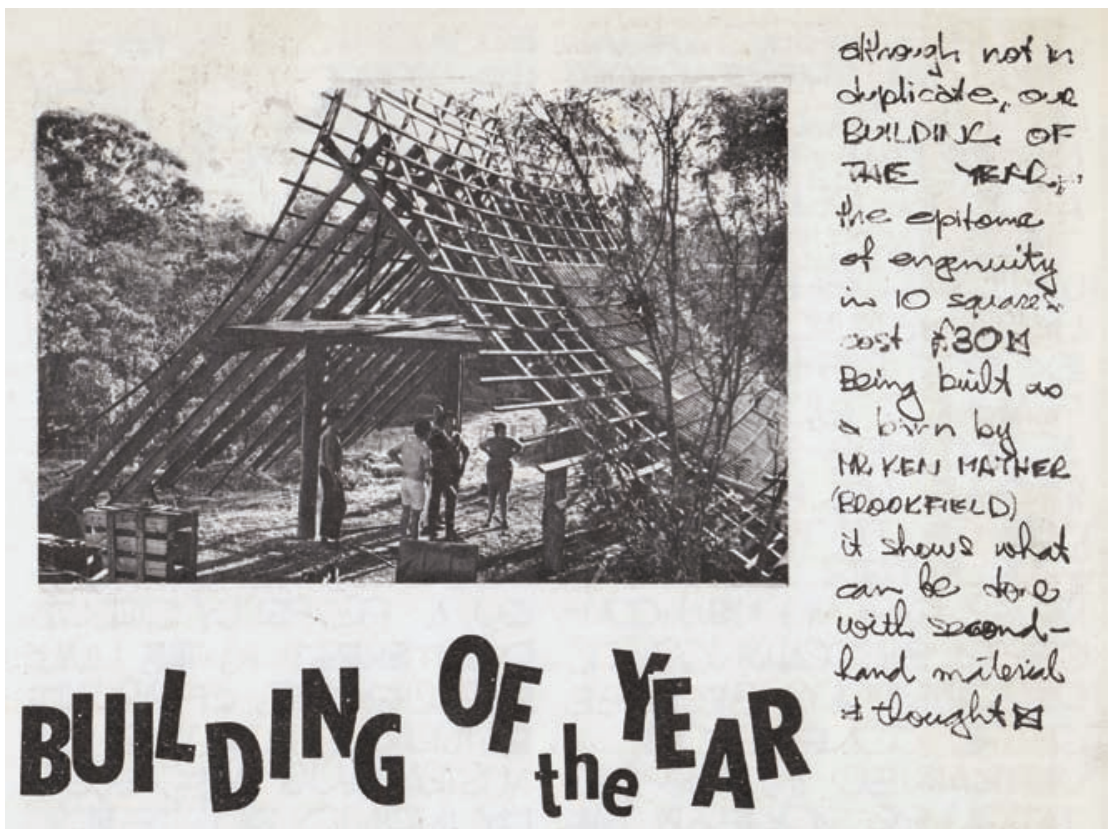

Article "Building of the Year" in the second edition of the Architecture Student Magazine Scarab showing a simple timber barn, which was labelled the "epitome of ingenuity."

Reproduced from Scarab 1 (1965) 
The new generation of post-war architects came to believe that architecture needed to reflect modern life while simultaneously contributing to a deeply needed sense of continuity and identity. This could be achieved through an established contextualism in both time and space. Some architects tried to engender a harmonious relationship to architecture's history, while others attempted to take into consideration the character and constraints of the specific locale in which they were operating-a concern for place (Williams-Goldhagen \& Legault, 20-21). In Queensland, this concern for place and its history_ "genius loci"-became a particularly poignant issue for a group of young architects whose training was taking them toward a professional establishment that was busily profiting from pro-development policies, which at times involved corrupt land rezoning and the destruction of Brisbane's built heritage. For Queensland-premier Bjelke-Petersen the number of cranes on the skyline offered a measure of the state's prosperity. Demolition became associated with economic growth and architectural heritage was-as his right hand man Richard Katter put it in a recent interviewconceived as the concern of a "... self-indulgent, citified sort of people that would be concerned about ridiculous things like that when people were going hungry" (Haughton, Ross \& Smith 2004).

\section{Happiness is a Three-Legged Dog}

Brisbane's angry young architects were certainly prolific. Shortly after organizing the National Student Conference-and while publishing (and writing) multiple editions of the Architecture Student Magazine-a group of architecture students produced a film, entitled Happiness is a Three-legged Dog. Drawing on ideas put forth by the 1964 student revolt in Berkeley, the film melds critique of the university under capitalism - factory education - and the oppressive socio-political climate with a critique of their perceived retrograde architecture training. In one of the first scenes, a group of students, all wearing black trousers, white shirts and black ties are lined up in a classroom and incited to repeat the words "truth, beauty, integrity" ad infinitum. The lecturer addresses the students not by their name but with a number. One of the students, number LX 4152/6, escapes this oppressive classroom environment to join a group of dissidents. Upon his escape he unplugs an electric chord. This results in the lecturer collapsing to the floor, revealing that he is not human but merely a mechanical component of the education "machine." Robert Riddel provided the script for the film. When asked what inspired him to write this story, he responded that at the time he felt that the local architectural education was appalling: not in the least concerned with "how are we going to learn how to live" (Riddel December 2012). 
Throughout the thirty-minute film, voiceovers utter statements that express the desire of the students to be free. After a woman is heard saying: "Everyone is born with a degree of intuition and creativity and this is fostered or suppressed by education and environment," a short twenty-second sequence shows a young girl twirling around and chanting "I'm a bird, I'm a bird," followed by an image of a soldier firing a shot into the air. The twirling girl is then seen falling to the ground. In less than half a minute, this sequence pithily conveys the contemporary state of mind of many young Brisbanites, distraught not only by the looming threat of conscription into a war that they did not condone, but also by the restraints of an oppressive local socio-political environment.
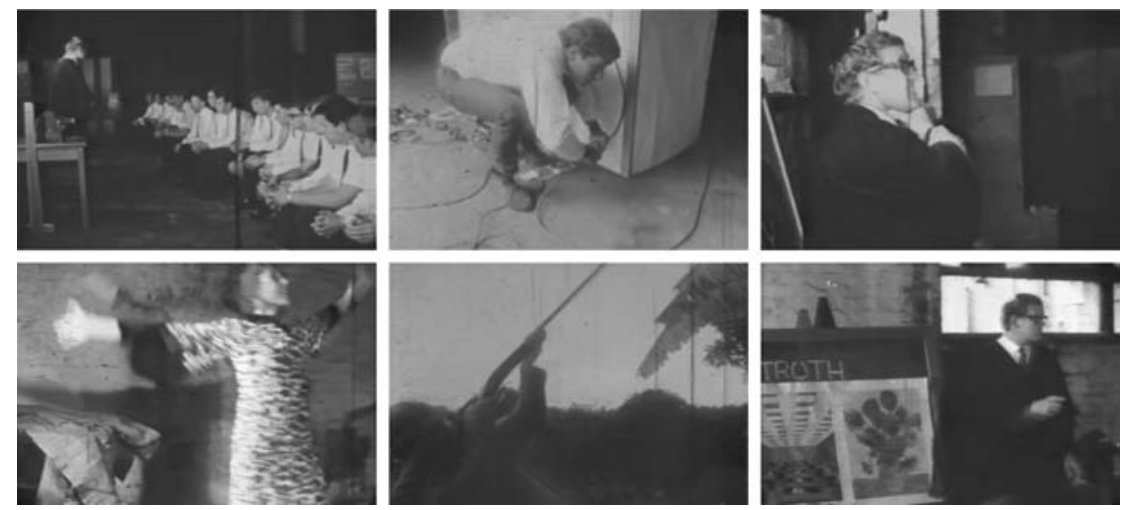

Six stills from the film Happiness is a Three Legged Dog, produced in the late 1960s by a group of architecture students from Brisbane. This film was written and directed by Anthony Airey.

Film: Anthony Airey. Private collection of Robert Riddel.

The film, however, not only criticizes the contemporary socio-political climate and education system, but also targets the architectural training and the discipline of architecture in general. In one scene, the "android" lecturer holds up a large print with two images: one depicting an open, sterile office space with desks organized on a grid, the other a reproduction of van Gogh's sunflowers. When the lecturer asks student LX 4152/6 which of the images he believes is better, he points at the sunflowers causing the other students to erupt in laughter. The film thus takes a stab at the modernist "form follows function" dogma, represented by the well-organized yet barren office area, and aligns itself with the growing criticism that was heard in the circles of the post-war architectural avant-garde, who believed that, in an attempt to develop a formal language based solely on 
physical needs, modernism had come to disregard architecture's ability to respond to people's emotional desires. This conviction also strongly comes to the fore in Riddel's explanation of the film's title: "My memory of it is that happiness was... central to all of our endeavours and good architecture, good spatial experience gave you a feeling of well-being, but it didn't have to be perfect... You could still have three legs and have that well-being... and you know when you are present in a piece of architecture with qualities that it gives you-it affects you in a full way. And, you feel this well-being feeling. It's your response to architecture" (Riddel December 2012).

\section{Art Week: Experiment}

By the early 1970s, change was imminent. In the Federal Election of December 1972, Australians voted for the Labor Party under Gough Whitlam, who immediately began a New Left program of reforms including the withdrawal of Australia from the war in Vietnam, new regulations against racial and gender discrimination, introduction of universal public health care, provision of substantial support for the arts, and abolition of university tuition fees. Queensland was, however, not entirely onboard with this spirit of reform. In 1971, the nationwide anti-apartheid protests against the touring South African rugby team-the racially selected Springboksled to the Queensland government declaring a state of emergency and giving the police license to violently suppress protests. Twenty students were hospitalized, and many others arrested and bundled into vans to the city's watch-house (Schultz 2008, 17). Friction was also felt in the School of Architecture, where the older cohort of lecturers had been complemented by a group of young, energized teachers, such as Bill Carr, Peter O'Gorman, and Ian Sinnamon. These angry (or perhaps rather ambitious and idealistic) young men determinedly wrought the course away from its stale modernist grounding towards a more varied curriculum, which included an assortment of creative experiences. Bruce Wolfe, who started the course in 1971 recalls: "We were introduced to other things like pottery and life drawings classes and things like that in the first year...I think that was perhaps instigated by Peter O'Gorman wanting to get a more touchy feely approach to design" (Wolfe 2013).

In 1972, determined that the UQ architecture students were insufficiently appraised in contemporary art, Bill Carr devised "Art Experience Week." Intended to shock the first, second, and third year students out of their familiar and (what he saw as a) parochial environment, Carr invited several renowned avant-garde artists to Brisbane. These included well-known film-maker Albie Thoms, art editors of the magazine $\mathrm{Oz}$ Gary Shead and Peter Kingston, and Sydney-based artists Franklin Johnson and Tim Johnson, one of the co-founders of the Inhibodress 
artists' atelier in Sydney, which provided a space for experimental performance art (The Art Week Controversy of 1972-Fact Sheet 2006).

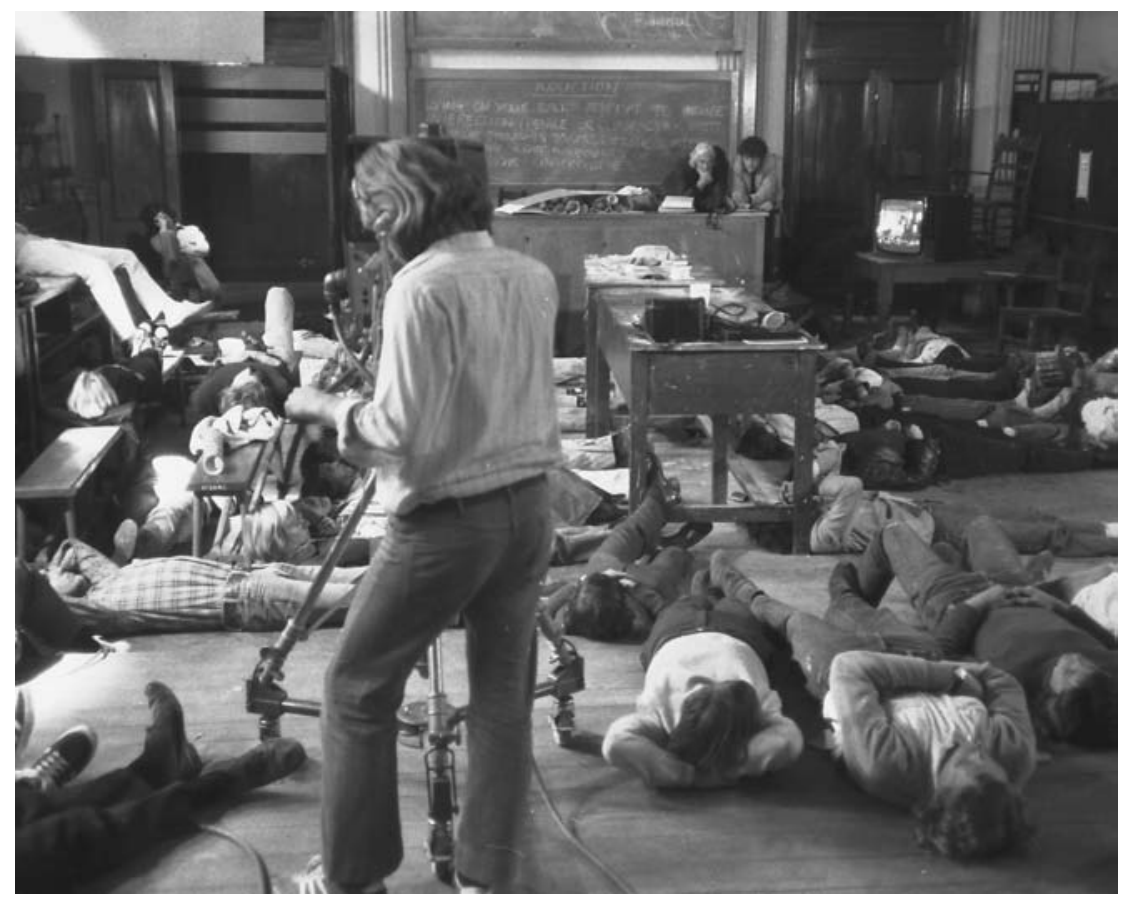

Students from the University of Queensland are shown lying on their back during "Art Experience Week," as they attempt to "produce an erection (penile, clitoral) by directing [their] thoughts towards erotic subjects..." This event was part of Tim Johnson's "Induction."

Photograph: Tim Johnson

Art Week started on Monday, $31^{\text {st }}$ of July, at the Masonic Hall in Alice Street, with Tim Johnson's "Induction." For this event, Johnson had written the following instructions for students on a blackboard: "Lying on your back attempt to produce an erection (penile, clitoral) by directing your thoughts towards erotic subjects and attempting slight movement of your organ inside your under clothes." Although this work was directed at making apparent the unbridgeable divide between body, socialized behavior, and psyche, it was not recognized as such and much less appreciated in conservative Queensland of the time. As soon as Bill Greig, then head of the School of Architecture at UQ, heard about the "incident," he ordered Johnson to "cease the eroticism" and informed the University's Vice-Chancellor. This set in 
motion a chain of events that unfolded over the next few days: Tim Johnson was dismissed, Art Week was cancelled on grounds of immorality, the validity of Johnson's work was questioned in State Parliament, and organizer Bill Carr was brought before the University's Dismissals Advisory Committee (Senate of the University of Queensland 1973). The Art Week controversy also caught the attention of several newspapers, including the The Courier Mail, which in September 1972 reported “... recently some Queensland University academics and students...staged an erotica display before men, women and children. Everything conceivable was performedmasturbation, homosexuality, sodomy, and sex deviation - in full view of everyone there...Only the filthiest and foulest things were performed" (Erotica Display at Uni-MLA Claim 1972).

The press that Art Week received was perceived by many as an attempt by the Bjelke-Petersen government to discredit the University of Queensland (and perhaps university education in general), which was a known bulwark of leftist propaganda and one of the main loci of political dissent. In a recent interview, artist Tim Johnson reflected that he and the other artists had been pawns in the game of the conservative forces: "they wanted to find ways to repress students a bit ... and when this [Art Week] happened, this was a good opportunity to make the students look bad or to make the universities feel that they needed more regulation" (Johnson 2014).

Whether or not Bill Greig's closing of Art Week was a matter of his being morally affronted, his animus for Bill Carr's style of education, or directly served a Government agenda, Johnson's diagnosis is in general correct. The establishment reaction to Art Week and the earlier student "happenings" failed to distinguish performance art from the sexual proclivities of youth, but rightly understood that a radical education, which emphasized a politics of the person and the body, was on a continuum with the violent clashes between the students and the police that continued through the 1970s. The repressive actions taken in the 1970s to clampdown on experiments in architectural education and silence students' critique of the Queensland administration was a fragment of a wider conservative reaction that led to the landslide victory of Bjelke-Petersen in the 1974 state election.

\section{Afterword}

In 1970s Queensland, the conservative backlash encouraged many young architects and students, whether angry or simply aspirational, to leave for Britain, America, or the more progressive southern Australian cities, while others chose to leave the architectural profession and took up jobs in other creative industries. Their ideological convictions, in combination with a strong ambition and 
imaginative power, gave them the courage to unshackle themselves from their oppressive surroundings and work towards an alternative future elsewhere. Even though many of the student leaders left and architecture became less overtly political, it would be a mistake to think of this simply as a return to order. Rather, the distance between university culture and the profession that the Sixties had produced became the state of affairs in the following decades.

In the late 1970s, critical regionalism flourished in the UQ School, and youth culture changed at the same time with the influence of New Wave and punk music, to which the School of Architecture contributed some notable bands (Stafford 2006). ${ }^{15}$ Short hair, tight black jeans, irony, melancholia, and an interest in semiotics and architectural history was felt by a new generation of students to be a complete repudiation of the "hippy shit" and naiveté of the previous decade. Internationally vanguard architectural culture had changed from social and technical utopianism to a new would-be politics at the etiolated level of culture critique. In the late twentieth century, the concept of a 'critical architecture' emerged, suggesting the possibility of a mode of architecture that opposes dominant economic and cultural strands, and proposed an alternative form of practice that does not reproduce prevailing values (Rendell 2006). This 'critical architecture' was a figment of the 'theory moment' in academia, which emerged in the last decades of the twentieth century. It matched the punk rock aesthetic of crudeness and unpleasingness, and made Neil Young and Buckminister Fuller equally risible.

The new punk formalism that appeared at UQ nevertheless relied on the foundations of the by then legendary 1967 conference, the Architecture Revues, and Art Week. Firstly, critical regionalist and post-modernist ideas in architecture provided a theoretical platform and cultural movement built on the foundations of the doubts about orthodox modernism of the earlier period. In a State run partly in the interests

15 Architectural theorists Alexander Tzonis and Liane Lefaivre first used the concept "critical regionalism" in the early 1980s to define a role for buildings and cities in a globalizing world. Coining "critical regionalism," they argued that designers should overcome biases favoring imported or local choices through questioning and reflection, considering the specifics of the actual situation, the region. While welcoming what the open world can offer, they should value the uniqueness of the "region," the quality of social ties as well as the physical and cultural resources. Critical regionalism thus not only strives to counter the placelessness and lack of identity of the International Style architecture, but also rejects the whimsical individualism and ornamentation of Postmodern architecture. Critical regionalism seeks to develop an architecture rooted in the modern tradition, but tied to differing geographical and cultural context. 
of corrupt property developers, attacking the functionalist and technological teleology of architectural modernism in the name of meaning and history was also an attack on the modernization of the Queensland economy that had hidden so many injustices. Secondly, after decades of misrule, it was apparent that oppression was deeply structured in Queensland's gerrymandered electoral system and government cronyism, and these were not susceptible to public pressure no matter how radical. The Bjelke-Petersen government held power until it miss-stepped by allowing an independent inquiry into police corruption in 1987 that lead to a spectacular implosion of its 32-year rule. ${ }^{16}$ By the 1980 s, opposition to the State and authorized forms of culture was not a moment of rebellion but the default condition of an intellectual life expressed in music and dress that would confront the bourgeoisie. The dissent of the Sixties had failed to change the order of society. However, it had appropriated repression as fuel to the next authentic counter-culture. In this way, the story of Brisbane's "angry young architects" reflects generalized tensions of 1960 s and 1970s counter-culture. While their actions failed to dismantle hegemonic mainstreams, they successfully established mores that became critical to later forms of dissent. Primary among those might have been the critical spirit of dissent: that art and politics not be unbound, and that each succeeding generation would bind them in their particular ways.

\section{References}

" $16^{\text {th }}$ Australian Architectural Convention, Brisbane." 1967. Architecture in Australia 56 (4): 620-656.

Addison, Rex. February 15, 2013. Interview by Janina Gosseye and Robert Riddel. http://www.qldarch.net.

Balint, Emery. 1967. “The Professional Builder?” Architecture in Australia 56 (4): 629-631.

"Building Ideas with Plastics." 1967. Courier Mail. May 27, 11.

Carr, Bill. 1965. “The Influence of the $19^{\text {th }}$ Century Vernacular Tradition on Contemporary Queensland Architecture." Scarab 1 (1): no page numbers given.

Untitled. April 1967. Cross-Section 174: no page numbers given.

Cummings, Malcolm. December 20, 2012. Interview by Janina Gosseye, John Macarthur and Andrew Wilson. http://www.qldarch.net.

16 See footnote 2. The inquiry was led by Tony Fitzgerald, QC. 
Evans, Raymond. 2004. “FOCO, Second Trades Hall." In Radical Brisbane. An Unruly History, ed, Raymond Evans \& Carole Ferrier, 273-276. Carlton, Victoria: The Vulgar Press.

Evans, Raymond. 2007. A History of Queensland. Melbourne: Cambridge University Press.

“Erotica Display at Uni._MLA Claim.” 1972. Courier Mail. September 21, 15.

Ferrier, Carole and Mansell, Ken. 2004. "Student Revolt, 1960s and 1970s. The University of Queensland, St. Lucia." In Radical Brisbane. An Unruly History, ed. Raymond Evans and Carole Ferrier. Carlton, Victoria: The Vulgar Press.

Fisher, Rod and Crozier, Brian, eds. 1994. The Queensland House: A Roof over our Heads. Brisbane: Queensland Museum.

Fitzgerald, Ross. 1984. “Censorship in Queensland 1954-83." Australian Journal of Politics and History 30 (3): 348-62.

Goad, Philip. 2012. "Universities." In The Encyclopedia of Australian Architecture, ed. Philip Goad and Julie Willis, 723-24. Port Melbourne: Cambridge University Press.

“Gwilliam.” 1967. ASM 5: no page numbers given.

Haughton, Andrew, Ross, Peter and Smith, Robyn. 2004. "ABC Rewind: Bellevue Hotel." http://www.abc.net.au/tv/rewind/txt/s1218262.htm.

Johnson, Tim. May 26, 2014. Interview by Janina Gosseye and John Macarthur. http://www.qldarch.net.

Kershaw, Jack. July 19, 2013. Interview by Janina Gosseye. http://www.qldarch.net.

Lambourne, Richard. October 4, 2013. Interview by Janina Gosseye and John Macarthur.

Memmott, Paul. February 13, 2013. Interview by Janina Gosseye and Deborah van der Plaat. http://www.qldarch.net.

Musgrave, Elizabeth. 2013. "What's 'out'... what's 'in' Revolution versus Evolution: John Dalton Architect as Pamphleteer." In Proceedings of the Society of Architectural Historians, Australia and New Zealand: 30, Open, ed. Alexandra Brown and Andrew Leach, 461-71. Gold Coast: SAHANZ.

Newell, Peter. 1965. "Rude Forefathers and Non Pedigree Architecture." Scarab 1 (1): no page numbers given.

Queensland Government. 2014. "State Education in Queensland." http://www. education.qld.gov.au/library/edhistory/state/.

Rasmussen, Steen Eiler. 1959. Experiencing Architecture. Cambridge, MA: MIT Press.

Rendell, Jane. 2006, "Critical Architecture: Introduction." The Journal of Architecture 10 (3): 227-228. 
Riddel, Robert. December 5, 2012. Interview by Janina Gosseye, John Macarthur and Elizabeth Musgrave. http://www.qldarch.net.

Riddel, Robert. October 18, 2012. Interview by Janina Gosseye and Deborah van der Plaat. http://wwwqldarch net.

Riddel, Robert. 1965. "Resurrection." Scarab 1 (2): no page numbers given.

Rudofsky, Bernard. 1964. Architecture without Architects: A Short Introduction to Non-pedigreed Architecture. New York: Museum of Modern Art.

Schultz, Julianne. 2008. "Disruptive Influences." Griffith Review 21: Hidden Queensland, ed. Julianne Schultz, 11-41. Australia: Griffith University.

Senate of the University of Queensland. 1973. Report of the Dismissals Advisory Committee. University of Queensland Archives.

Sinnamon, Ian and Keniger, Michael. 1987. Ideas in Practice: Queensland's University Department of Architecture, 1937-1987. Brisbane.

Stafford, Andrew. 2006. Pig City: From the Saints to Savage Garden. Brisbane: University of Queensland Press.

Stringer, Richard. December 10, 2012. Interview by Janina Gosseye, John Macarthur and Deborah van der Plaat. http://www.qldarch.net.

Taylor, Jennifer. 1986. Australian Architecture since 1960. Sydney: The Law Book Company Limited.

“The 'Art Week' Controversy of 1972-FACT SHEET." 2006. Turrbal-Jagera: The University of Queensland Art Projects 2006, exhibition catalogue. Brisbane: University Art Museum, 38-39.

Tyrell, Ralph and Twidale, Neville. January 15, 2013. Interview by Janina Gosseye and Don Watson. http://www.qldarch.net.

Williams-Goldhagen, Sarah and Legault, Réjean, eds. 2000. Anxious Modernisms. Experimentation in Postwar Architectural Culture. Montréal/ Cambridge, MA: Canadian Centre for Architecture/ MIT Press.

Wolfe, Bruce. September 26, 2013. Interview by Janina Gosseye and John Macarthur. http://www.qldarch.net. 



\title{
"But That is Perhaps Why I Can Talk of Where I Want to Be without Always Being Dragged Back to My Starting Point": Rethinking and $\operatorname{Re}(-)$ Membering Czech and Slovak Histories of Violence and Dissidence through the Historical "Infranovel"
}

\begin{abstract}
In $H H h H$, a historical "infranovel" published in French in 2010 and translated into English in 2013, Laurent Binet's conscious “otherness” to Central Europe, particularly Czech and Slovak cultures and histories, sets him "free to dream" of a different place/time and free to imagine as well as introduce ghosts of the obscure and unknown "subaltern" involved, thereby adding critical dimensions to the postmodernist rethinking and re(-) membering of the region's histories of violence and dissidence.
\end{abstract}

From Fritz Lang's 1943 film entitled Hangmen Also Die! to Lidice (2011), and from Jiří Weil's Na střeše je Mendelssohn (Mendelssohn Is on the Roof [1960]) to Alan Burgess's Seven Men at Daybreak (1960) and Gerald Brennan's Resistance (2012), Operation Anthropoid, as well as the merciless Nazi reprisals, one of the darkest chapters of Czech and Slovak histories of oppression and resistance, has been portrayed and recounted in a number of films and literary works. Though these cinematic and literary portrayals and adaptations of the assassination in Prague on 27 May 1942 of Reinhard Heydrich, Reichsprotektor of the Protectorate of Bohemia and Moravia, tend to be regarded as classic indisputable resources and references in their own right, I argue in this paper that the representation of histories of violence and dissent nevertheless remains and should remain problematic. The problem lies in the notion that such representation entails rearranging as well as manipulating narrative elements to tell a (hi)story, an act which is always subjected to the totalitarianism of what Jean-François Lyotard refers to as "grand narrative," or "metanarrative":

One of the fundamental attacks postmodernism subjects modernism to is on the latter's belief in a "grand narrative." It is a rejection of the idea that the ultimate truth associated with a grand narrative is possible and that the world as experienced is as a result of hidden structures. A grand narrative or metanarrative can also be understood as an ideology or paradigm; a system of thought and belief. (Du Toit 2011,86) 
In The Postmodern Condition (1979), where he revises the notion of knowledge and proposes the tenets of the postmodern aesthetic and intellectual movement, Lyotard (1985, xxiv) defines postmodernism as "incredulity toward metanarratives." He thus signals a break with modernism, which despite its subversive and experimental tendencies is nevertheless firmly based on the belief in the grand narrative. He writes,

What, then, is the postmodern? What place does it or does it not occupy in the vertiginous work of the questions hurled at the rules of image and narration? It is undoubtedly a part of the modern. All that has been received, if only yesterday (modo, modo, Petronius used to say), must be suspected. What space does Cézanne challenge? The Impressionists'. What object do Picasso and Braque attack? Cézanne's. What presupposition does Duchamp break with in 1912? That which says one must make a painting, be it cubist. And Buren questions that other presupposition which he believes had survived untouched by the work of Duchamp: the place of presentation of the work. In an amazing acceleration, the generations precipitate themselves. A work can become modern only if it is first postmodern. Postmodernism thus understood is not modernism at its end but in the nascent state, and this state is constant. (Lyotard 1985, 79)

The narrative structure of a story, the order and manner in which a story is presented to readers, tends to reflect and uphold the authority of such "large-scale theories and philosophies of the world which, according to Lyotard, should be viewed with deep scepticism" (Du Toit 2011, 86). Such is "the crisis of narratives" which Lyotard (1985, xxiii) emphasises in his writing and which Fredric Jameson (1985, viii) explicates and expands to include what he refers to as the "crisis of representation" in his foreword to Lyotard's seminal book. For Jameson (1985, viii), the "crisis of representation" stems from one's tendency to uphold the supremacy of universal truth without questioning and one's failure to see how belief in such "essentially realistic epistemology" (Jameson 1985, viii) leads one to think that representation is a faithful reproduction of truth, which lies in its entire essence outside subjectivity:

It is in terms of this crisis that the transition, in the history of form, from a novelistic "realism" of the Lukácsean variety to the various now classical "high" modernisms, has been described: the cognitive vocation of science would however seem even more disastrously impaired by the analogous shift from a representational to a nonrepresentational practice. (Jameson 1985, viii-ix)

Returning to Operation Anthropoid and its filmic and literary representations, the story of a Czech soldier and a Slovak soldier's attempt to assassinate Adolf Hitler's prominent henchman ("the hangman" of Prague) and architect of the Final Solution of the Jewish question, which led to the Holocaust, seems simple enough to be (re)told and (re-)presented in its entirety. However, as Lyotard and 
Jameson point out, universal truth, along with the grand narrative which renders all events in human history representational, is a myth. In this paper, I propose that Laurent Binet's novel entitled, $\mathrm{HHhH}$, published in French in 2010 and translated into English in 2013, exposes the "nonrepresentational" aspects of history and reveals how a writer grapples with his/her authorial urge to impose order and recount the story as a whole to fit the scheme of metanarrative whilst struggling with the knowledge that such an urge can never do justice to the (hi)story. $\mathrm{HHhH}$, as I shall demonstrate, offers alternative means and methods of narrating a (hi) story which Johanna Lindbladh $(2003,5)$ postulates in The Poetics of Memory in Post-Totalitarian Narration: "individual and collective memory is enigmatic, fragmentated, intimately connected to our senses and feelings, and thereby in need of an alternative epistemology, challenging traditional definitions of knowledge and truth." By exposing the process of historical fiction writing, Binet draws attention to two aspects of dissent in his work. The first is dissent on the level of content-the story of Operation Anthropoid and its tragic ending. The second is dissent on the level of narrative form. Binet calls $\mathrm{HHhH}$ an "infranovel," in which combination of journalism and fiction serves as an alternative genre to the traditional historical novel. Binet's experimental tendency tangibly manifests in the novel's structure. $\mathrm{HHhH}$, containing no page numbers, is markedly divided into two hundred and fifty-seven random disproportionate sections. Why are these two levels of dissent important? I propose that, though the underlying causes of dissidence are found foremost in political protests and activism, one cannot deny the significance of the means and methods through which such causes, or political messages, are activated and communicated to the public. The study and analysis of literary works, through which one comes to investigate not only the content but also the stylistics of written words, provides a critical space where the fundamental concepts of political resistance and acts of dissent are questioned and revised.

$* * *$

At the level of content, it is undeniable that Operation Anthropoid was part of the Czechoslovak resistance movement and orchestrated by the Czech government in exile. However, the narrative of such an act of dissent cannot be recounted in one coherent metanarrative, as it is disputable whether the assassination of Heydrich yielded anything more than horrifying consequences, some of which are described on the dust jacket of Jan Wiener's (1969) The Assassination of Heydrich:

The repercussions of Heydrich's death shook the world. To Hitler, Heydrich was an "irreplaceable" SS chief. To the Czech people, he was a symbol of the terror and horror of the Nazi occupation. In reprisal, Hitler ordered a massive slaughter of the Czech "resistors" 
and totally demolished the small town of Lidice demanding that grass be planted where the town stood and that the name be erased from all maps.

Some historians have posited that the post-assassination retribution was far greater than the symbolic nationalist gesture brought about by Heydrich's death. The villages of Lidice and Ležáky, for example, were razed to the ground as a result of false accusations. Their residents were terrorised and murdered:

On the morning of 10 June 1942 the SS shot Lidice's entire male population and burned the village to the ground. Lidice's women and those of its children who failed to meet "racial" criteria were deported to concentration camps... Two weeks later, the SS murdered all twenty-four adults in the village of Ležáky and similarly divided its children. (Frommer 2005, 19-20)

For the loss of Heydrich's life, the Czech citizens paid the high price with the currency of their own lives: "In the wave of terror that followed Heydrich's assassination, the Germans arrested 3,188 Czechs, sentenced 1,357 to death, and executed 679 , most for having 'approved the assassination.' Hitler had initially called for 10,000 Czechs to be summarily shot..." (Frommer 2005, 20). Though Laurent Binet's treatment of the subject of Nazi retribution does not undermine Operation Anthropoid as a symbolic act of resistance, $\mathrm{HHhH}$ nevertheless highlights the gravity of the incident's repercussions:

The most appropriate tribute paid by the Nazis to Heydrich's memory was not Hitler's speech at his zealous servant's funeral, but probably this: in July 1942 the programme to exterminate all Poland's Jews began, with the opening of Belzec, Sobibor, and Treblinka. Between July 1942 and October 1943, more than two million Jews and almost fifty thousand Romany will die as part of this programme. Its code name is Aktion Reinhard. (Binet 2013, Section 252)

Apart from Hitler's horrifying tribute to Heydrich, an important event which followed Heydrich's death renders Binet's novel, as well as history, "unfinishable":

My story is finished and my book should be, too, but I'm discovering that it's impossible to be finished with a story like this. My father calls me to read out something he copied down at the Museum of Man in Paris, where he visited an exhibition on the recently deceased Germaine Tillion, an anthropologist and Resistance fighter who was sent to Ravensbrück. This is what the text said:

The vivisection experiments on 74 young female prisoners constitute one of Ravensbrück's most sinister episodes. The experiments, conducted between August ' 42 and August '43, consisted of mutilating operations aimed at reproducing the injuries that caused the death of Reinhard Heydrich, the gauleiter of Czechoslovakia. Professor Gerhardt, having been unable to save Heydrich from a gaseous gangrene, wished to prove that the use of sulphonamides would have made no difference. So he deliberately infected the young women with viruses, and many of them died. (Binet 2013, Section 256) 
Operation Anthropoid as an act of dissidence resists the authority of the realist grand narrative because the mission, though accomplished at the expense of the death of seven soldiers in an Eastern Orthodox church in Prague (where they were seeking refuge), triggered reprisals on a massive scale:

As far as the resistance strategy is concerned, the assassination of Heydrich was a classic example of an attack against a powerful enemy undertaken with inadequate forces and disastrous consequences. It showed how counterproductive violence can be, when it is employed in the wrong place and at the wrong time. Throughout the entire occupation period, the Czech underground and the exiles in London improvised in a vain search for the right strategy. Their failure makes evident the need for advance planning of underground resistance; such planning should be part of the national defense effort in peacetime. (Mastný 1971, 224)

From the chosen extracts, I propose that it is through literature, such as Binet's $\mathrm{HHhH}$, and through literary analysis, which is this paper's methodology, that one can come to understand the "doubleness" of dissent. Like pharmakon, a Greek word which paradoxically means both "poison" and "antidote," political resistance and acts of dissidence can be an antidote to social injustice but, at the same time, a poison that triggers and aggravates the violence of tyranny.

In the next section, I shall offer an overview of historical fiction and Binet's dissidence towards the totalitarianism of grand narratives/metanarratives, the kind of totalitarianism which underpins not only the genre of historical fiction, but also the concept of history.

In his novel, Binet describes his preparatory work as a writer of historical fiction:

I also read lots of historical novels, to see how others deal with the genre's constraints. Some are keen to demonstrate their extreme accuracy, others don't bother, and a few manage skilfully to skirt around the historical truth without inventing too much. I am struck all the same by the fact that, in every case, fiction wins out over history. It's logical, I suppose, but I have trouble getting my head around it. (Binet 2013, Section 11)

Binet's dismay, caused by witnessing how other writers of historical fiction tend to be defeated by the unattainability of "accuracy" and "historical truth" in recounting and representing history, is also part and parcel of Lyotard's "crisis of narratives" and Jameson's "crisis of representation." To better understand Binet's struggle with such "constraints," it might be useful to evoke Harry E. Shaw's definitions of historical fiction in The Forms of Historical Fiction as a starting point:

The historical novel raises in an acute form a question common to all mimetic works of art-the relationship of the individual to the general, of particulars to universals. Such 
problems tend to remain submerged in most literary works. Several things bring them to the surface in the historical novel. Because historical novelists depict ages significantly different from their own and may aspire to represent the workings of historical process itself, they are faced with the task of creating characters that represent social groups and historical trends. But creating such characters involves certain inherent difficulties. This is a major reason for the problem with historical novels. (Shaw 1983, 30)

The crises of narratives and representation are inherent within the genre of historical fiction. $\mathrm{HHhH}^{\prime}$ 's title might seem to suggest that the novel's main focus is on the life story of Reinhard Heydrich, the Nazi prototype par excellence: " 'HHhH, they say in the SS: Himmlers Hirn heisst Heydrich-Himmler's brain is called Heydrich" (Binet 2013, Section 108). Instead, Binet (2013, Section 88) intentionally puts Jozef Gabčík and Jan Kubiš, the two parachutists assigned to assassinate Heydrich, on centre stage: "Whenever I talk about the book I'm writing, I say, 'My book on Heydrich.' But Heydrich is not supposed to be the main character." Such a conscious choice aggravates the problem. It would have been easier to write a book about Heydrich, the cold-hearted villain, whose life and death have been extensively documented. Instead, the novel begins with a scene in which readers are immediately introduced to Jozef Gabčík, the Slovak parachutist involved in Operation Anthropoid whose Sten gun jammed at the moment of his close encounter with Reinhard Heydrich:

Gabčík - that's his name-really did exist. Lying alone on a little iron bed, did he hear, from outside, beyond the shutters of a darkened apartment, the unmistakable creaking of the Prague tramways? I want to believe so. I know Prague well, so I can imagine the tram's number (but perhaps it's changed?), its route, and the place where Gabčík waits, thinking and listening. We are at the corner of Vyšehradská and Trojická. The number 18 tram (or the number 22) has stopped in front of the Botanical Gardens. We are, most important, in 1942. (Binet 2013, Section 1)

Binet confesses in his novel that imagining how it was like to be Gabčík, the lessknown hero of the two parachutists, is not an easy feat. His affirmation that the character "really did exist" (Binet 2013, Section 1), along with his insertion of the images of Prague in the present day into his depiction of Gabčík's Prague in 1942, puts readers in medias res of the Operation Anthropoid story as well as of historical fiction in the making. Binet's description of Gabčík also draws readers' attention to the less-known anti-Nazi resistance movements and activities established and participated in by the people of Slovakia when their country became Nazi Germany's satellite state under Josef Tiso.

I contend that it is through the stories of less-known heroes, or less-known characters of history, that one can come to imagine the nameless and, in some cases, faceless individuals who, despite their obscurity, can rightfully be regarded 
as movers and shakers of historical events. In the next section, I shall elaborate on my contention through a discussion of the subaltern in Binet's $\mathrm{HHhH}$.

One of the significant effects of Binet's "re(-)presenting" the past, or situating the past in the present, is that readers are not only made consciously aware of the historical fiction genre's devices and limitations, but also invited to question their own concepts and conceptualisation of history:

The problems historical novels have with history and we have with historical novels are potentially instructive. They can help to reveal limits in the esthetic forms we most prizeknowledge that matters for those who employ imaginative forms to make sense of the world. A clearer understanding of the workings of historical fiction can also clarify certain aspects of the nature of history itself, and of our situations as historical beings. (Shaw 1983, 9)

A more complacent writer might see no difficulty or dilemma in recounting the story of two men, a Czech and a Slovak, who parachuted down to assassinate Reinhard Heydrich. A less thoughtful reader might not be moved by the incident, despite the fact that it took place not in the distant past but less than a hundred years ago. As a "historical being" himself, Binet does not make it a secret that he has difficulty conjuring the world of the past. Operation Anthropoid is clearly not a story which can be re(-)membered in and through a simple plot. The simplicity of the story is deceptive. Operation Anthropoid was a success; Heydrich later died of his injuries caused by Jan Kubiš (though only at the expense of subsequent tragic deaths of the parachutists, their colleagues, the people who helped and sheltered them, as well as other innocent people who perished to sate Hitler's violent urges). This historical event involves many other characters, in fact; real people whose lives and the minute details which make up their existence are beyond the knowledge of the writer:

To begin with, this seemed a simple-enough story to tell. Two men have to kill a third man. They succeed, or not, and that's the end or nearly. I thought of all the other people as mere ghosts who would glide elegantly across the tapestry of history. Ghosts have to be looked after, and that requires great care-I knew that. On the other hand, what I didn't know (but should have guessed) is that a ghost desires only one thing: to live again. Personally, I'd like nothing better, but I am constrained by the needs of my story. I can't keep leaving space for this ever-growing army of shadows, these ghosts who-perhaps to avenge themselves for the meager care I show them-are haunting me. (Binet 2013, Section 175)

The "ghosts" of the historical "subaltern" are those to whom Binet dedicates his novel. Here, I refer to Gayatri Chakravorty Spivak's definitions of the subaltern in “Can the Subaltern Speak?” In this essay, Spivak asks whether or not marginalised 
people, who have been silenced by and confined within the oppressive language system of the elite, can truly express themselves (Spivak 2010, 37). The language and history of the subaltern are made up of fragmented heterogeneous voices, which find no precise outlet in the very vocabulary and power system that put them in the margins of society. Spivak argues that the subaltern cannot speak. Binet's novel can be read as an attempt to make the subaltern speak-to resurrect or pay tribute to the obscure, even nameless and faceless, people who existed on the margins of history: "I tremble with guilt at the thought of all those hundreds those thousands, whom I have allowed to die in anonymity. But I want to believe that people exist even if we don't speak of them" (Binet 2013, Section 251). To uncover the partially known is a challenging task, but to uncover the unknown is an impossible task:

I examine a map of Prague, marking the locations of the families who helped and sheltered the parachutists. Almost all of them paid with their lives-men, women, and children. The Svatoš family, a few feet from the Charles Bridge; the Ogoun family, near the castle; the Novak, Moravec, Zelenka, and Fafek families, all farther east. Each member of each of these families would deserve his or her own book-an account of their involvement with the Resistance until the tragic dénouement of Mauthausen. How many forgotten heroes sleep in history's great cemetery? Thousands, millions of Fafeks and Moravecs, of Novaks and Zelenkas...

The dead are dead, and it makes no difference to them whether I pay homage to their deeds. But for us, the living, it does mean something. Memory is of no use to the remembered, only to those who remember. We build ourselves with memory and console ourselves with memory. No reader could possibly retain this list of names, so why write it? For you to remember them, I would have to turn them into characters. Unfair, but there you go. I know already that only the Moravecs, and perhaps the Fafeks, will find a place I my story. The Svatošes, the Novaks, the Zelenkas-not to mention all those whose names or existence I'm unaware of-will return to their oblivion. But in the end a name is just a name. I think of them all. I want to tell them. And if no one hears me, that doesn't matter. Not to them, and not to me. One day, perhaps, someone in need to solace will write the story of the Novaks and the Svatošes, of the Zelenkas and the Fafeks. (Binet 2013, Section 150)

Binet also expresses his frustration as a historical fiction writer who is forced by the genre's rules and constraints to rearrange the elements of history and fit them into the mould of one coherent story while seeking ways to do justice to history's subaltern:

I'm fighting a losing battle. I can't tell this story the way it should be told. This whole hotchpotch of characters, events, dates, and the infinite branching of cause and effectand these people, these real people who actually existed. I'm barely able to mention a tiny fragment of their lives, their actions, their thoughts. I keep banging my head against the wall of history. And I look up and see, growing all over it-even higher and denser, like a creeping ivy - the unmappable pattern of causality. (Binet 2013, Section 150) 
The "unmappable pattern of causality" (Binet 2013, Section 150), when it comes to the depiction of nameless and faceless people involved in and affected by Operation Anthropoid, becomes even more "unmappable" as Binet is consciously aware he is writing a historical novel (set in Prague, from the point of view of a French man living in the twentieth century). Binet, as a non-Czech and non-Slovak writer aspiring to (re-)present a landmark event in the Czechoslovak history of dissidence, feels that he can identify with the subaltern, whose names and heroic deeds are scarcely mentioned in history books let alone remembered by the public. Binet's "outsider" status is further emphasised in his reference to Marjane Satrapi. In an interview, Satrapi highlights the notion that a writer's own birthplace, as well as place of residence, justifies his/her authority and credibility to write about a certain place:

'I adore Kundera, but the novel of his I love the least is the one set in Paris. Because he's not truly in his element. As if he were wearing a very beautiful jacket that was just a little bit too big or a little bit too small for him [laughs]. But when Milos and Pavel are walking through Prague, I believe it totally.'

This is Marjane Satrapi, in an interview given to Les Inrockuptibles magazine to promote the release of her beautiful film, Persepolis. I feel a vague sense of anxiety as I read this. Flicking through the magazine in the apartment of a young woman, I confide my anxiety to her. 'Yes, but you've been to Prague,' she reassures me. 'You've lived there, you love that city.' But the same is true for Kundera and Paris...Will Marjane Satrapi sense that I didn't grow up in Prague? ... But does that mean she'll think my story is happening in Paris, where I was born, and not in Prague, the city my whole being yearns for? Will there be images of Paris in her mind when I drive the Mercedes to Holešovice, near the Troie Bridge? (Binet 2013, Section 179)

According to Satrapi, Kundera is "not truly in his element" (Binet 2013, Section 179) when it comes to his depiction of Paris because he was born and grew up in Prague, not Paris. If the legitimacy and verisimilitude of a story depend solely upon the writer's nationality, then it can be said that Binet (2013, Section 179) is also "not truly in his element" when it comes to his depiction of Prague because he was born and grew up in Paris, not Prague. Binet justifies his stance as a French writer recounting the story of a historical event set in Prague as follows:

Unlike Marjane Satrapi, Milan Kundera, Jan Kubiš, and Jozef Gabčík, I am not a political exile. But that is perhaps why I can talk of where I want to be without always being dragged back to my starting point. I don't owe my homeland anything, and I don't have a score to settle with it. For Paris, I feel neither the heartbreaking nostalgia nor the melancholy disenchantment of the great exiles. That is why I am free to dream of Prague. (Binet 2013, Section 179)

Binet refutes Satrapi's theory by admitting that his visions of Prague are products of his dream, which is devoid of an exile's nostalgic longing for home and political 
agenda. He also challenges Satrapi by declaring that he conjures up his visual and textual images of Prague from those presented by the media: "Prague in 1942 looks like a black-and-white photo. The passing men wear crumpled hats and dark suits, while the women wear those fitted skirts that make them all look like secretaries. I know this-I have the photos on my desk" (Binet 2013, Section 193). I argue that Binet's statement here reflects dissidence not only towards the authority of linear and unifying metanarratives, but towards the authority of a writer's place of birth over his/her writing as well. Binet's conscious "otherness" to Central Europe, particularly Czech and Slovak cultures and histories, sets him "free to dream" of a different place/ time and free to imagine as well as introduce ghosts of the obscure and unknown "subaltern" involved, thereby adding critical dimensions to the postcolonial rethinking and re(-)membering of the region's histories of violence and dissidence.

$* * *$

Dissent on the level of $H H h H$ 's narrative form can be seen manifested in Binet's coinage of the term "infranovel": "I think I'm beginning to understand. What I'm writing is an infranovel" (Binet 2013, Section 205). Though he does not provide readers with a clear definition of what he means by that specific term, Binet leaves clues and hints from which it can be inferred. The Latin prefix "infra" means "below". From the extracts which I have analysed in this paper, as well as the following one, we can see that Binet offers readers the many subnarratives which lie beneath or below the surface not only of his book, but of historical fiction as a genre. Note that the bottom-to-top metaphor which the prefix "infra" connotes subverts the omniscient gaze from top to bottom often imposed on an analysed object. As the attempt to tell a story can never escape the manipulation of the storyteller/writer, who sets out to reorder the sequence of events and weave the many strands of narrative into one coherent grand narrative, the recounting of history through words and texts, likewise, can never be objective. The literary (re-)presentation of historical events is done through a particular point of view in a particular time and place. History should therefore be read in relation to, as well as by taking into account, that particular time and space in which it is (re) told. One must avoid imposing fixity upon history. Instead of looking at history from above and treating it like chess pieces to be manoeuvred at will, one must, as the prefix "infra" in "infranovel" suggests, venture to understand history from below. A historical "infranovel" like Binet's $H H h H$ has the power to transform the god-like chess player into one of the chess pieces of history, imaginatively (re) living the events. A historical "infranovel" also puts into question the concept of language as neutral medium in historiography. 
To this effect, Binet, like Hayden White in Metahistory, blurs the boundaries between history and fiction:

It is sometimes said that the aim of the historian is to explain the past by "finding," "identifying," or "uncovering" the "stories" that lie buried in chronicles; and that the difference between "history" and "fiction" resides in the fact that the historian "finds" his stories, whereas the fiction writer "invents" his. This conception of the historian's task, however, obscures the extent to which "invention" also plays a part in the historian's operations. (White 1975, 6-7)

By outlining and acknowledging the processes and limitations of historical fiction writing, Binet exposes how historical fiction writers, historical film producers, and even historians treat history as a narrative prose discourse that classifies and regulates past events in order to establish and re(-)present them as models or as coherent grand narratives. The following extract is an example of the ways in which Binet's "infranovel" uncovers the process and techniques of historiography and historical fiction writing, as well as the underlying concepts of history "below" the texts one reads. Here, readers encounter a dialogue between young Heydrich and his father:

'Why is there a war, Father?'

'Because France and England are jealous of Germany, my son.'

'Why are they jealous?'

'Because the Germans are stronger than they are.' (Binet 2013, Section 14)

There is nothing more artificial in a historical narrative than this kind of dialoguereconstructed from more or less firsthand accounts with the idea of breathing life into the dead pages of history. In stylistic terms, this process has certain similarities which hypotyposis, which means making a scene so lifelike that it gives the reader the impression he can see it with his own eyes. When a writer tries to bring a conversation back to life in this way, the result is often contrived and the effect the opposite of that desired: you see too clearly the strings controlling the puppets, you hear too distinctly the author's voice in the mouths of these historical figures. (Binet 2013, Section 15)

The invented dialogue is immediately followed by Binet's own commentary, in which he points out the absurdity of a writer's extreme quest for verisimilitude. $\mathrm{HHhH}$ as a historical "infranovel" is a book which critiques itself, dissecting the creative process and reading experience in meticulous detail. In re(-)membering, or commemorating and reinventing in fiction form, this history of dissent, Binet chooses to avoid the authorial pretension found in history textbooks: "But I've said that I don't want to write a historical handbook. This story is personal. That's why my visions sometimes get mixed up with the known facts. It's just how it is" (Binet 2013, Section 91). He also chooses to avoid the extreme "life-like" rhetoric of hypotyposis: "inventing a character in order to understand historical facts is like fabricating evidence. Or rather, in the words of my brother-in-law, with whom 
I've discussed all this: It's like planting false proof at a crime scene where the floor is already strewn with incriminating evidence" (Binet 2013, Section 192). HHhH as a historical infranovel therefore becomes part of the history of dissidence as it seeks to revolutionise the genre of historical writing and mainstream conceptualisation of history. In Lyotard's (1985, xxv) words, "invention is always born of dissension. Postmodern knowledge is not simply a tool of the authorities; it refines our sensitivity to differences and reinforces our ability to tolerate the incommensurable. Its principle is not the expert's homology, but the inventor's paralogy." Binet's invented genre of "infranovel" aggravates his anti-grand narrative stance. In a historical "infranovel," the writer's life becomes closely entwined with the lives of the obscure, or the subaltern, in history as well as the less obscure people, such as the key players involved in Operation Anthropoid. However, Binet is also aware of the dangers of overstylised representation of history, particularly historical figures like Reinhard Heydrich:

It is obviously impossible that I-son of a Jewish mother and a Communist father, brought up on the republican values of the most progressive French petite bourgeoisie and immersed through my literary studies in the humanism of Montaigne and the philosophy of the Enlightenment, the Surrealist revolution and the Existentialist worldview-could ever be tempted to 'sympathize' with anything to do with Nazism, in any shape or form.

But I must, once more, bow down before the limitless and nefarious power of literature. Because this dream proves beyond doubt that, with his larger-than-life, storybook aura, Heydrich impresses me. (Binet 2013, Section 41)

Literary devices can add allure even to one of the vilest villains in history. Though he knows full well that Heydrich as a historical figure should by all means be condemned for the crimes he committed against humanity, Binet is nevertheless impressed by the larger-than-life character into which his writing has transformed Heydrich. What is to be inferred from this? I propose the following: like history, literature should be handled with caution and with a critical mind. As Binet demonstrates in the above passage, the pharmakon that is literature possesses the power to render heroic even one of Hitler's most trusted henchmen, who not only orchestrated the Final Solution, sending around six million Jews to their death, but also gave out orders for the staging of the Gleiwitz incident on 31 August, 1939, a staged attack by Nazi forces posing as Poles against the German radio station in Gleiwitz. ${ }^{1}$

1 According to the caption of a photo of Hitler holding "photographic proof" of the "attack by Polish bandits" on the back cover Edouard Calic's Reinhard Heydrich, this "was used as a pretext for the German invasion of Poland, which triggered World War II" (Calic 1985). 
Though $\mathrm{HHhH}$ as a historical "infranovel" is not a direct treatment of the history of Soviet occupation of Czechoslovakia, it nevertheless suggests that the history of Nazi occupation is far from being the final ending of the region's historical narrative. The history of the Nazi regime and anti-Nazi resistance in Czechoslovakia recounted in $\mathrm{HHhH}$ can be read as the Derridean trace and spectre of Central Europe's uncanny past's future, which was to come after the end of the Second World War, namely the Soviet regime and anti-Soviet resistance in Czechoslovakia. I argue that when one treats history as an open-ended story, or as a foreshadowing of events to come, one can see the traces of future regimes and spectres of political ideologies to rebel against: the Soviet regime and totalitarianism. To wit, Derrida's definition of the "trace":

[I]f the trace refers to an absolute past, it is because it obliges us to think a past that can no longer be understood in the form of a modified presence, as a present-past. Since past has always signified present-past, the absolute past that is retained in the trace no longer rigorously merits the name "past." ... With the same precaution and under the same erasure, it may be said that its passivity is also its relationship with the "future." The concepts of present, past, and future, everything in the concepts of time and history which implies evidence of them-the metaphysical concept of time in general-cannot adequately describe the structure of the trace. (Derrida 1997, 66-67)

There is no hard evidence which accounts for the existence of trace. However, it can be said that trace is a presence of the absence of concrete evidence of the past. By evoking Wilhelm Keitel's statement in one of the Nuremberg trial sessions in 1946, Binet evokes in the readers' minds the near future-of-the-past Soviet regime which would later subject the region of Czechoslovakia under its power:

In 1946, at Nuremberg, the representative for Czechoslovakia will ask Keitel, the German chief of staff: 'Would the Reich have attacked Czechoslovakia in 1938 if the Western powers had supported Prague? To which Keitel will reply: 'Definitely not. Militarily, we weren't strong enough.'

Hitler can curse all he likes. The truth is that France and Britain opened a door to which he did not have the key. And, obviously, by displaying such servility, encouraged him to start again. (Binet 2013, Section 74)

In the totalitarian poker arena, both the Nazi regime and the Soviet regime struggle to win the pot and maintain their authority by means of pure bluffing, or by means of creating illusions and propagandas which will make their opponents fold. Even the Soviet soldiers were subjected to blinding propaganda and came to call the bluff only when they reached Eastern Europe and saw the wealth of the region with their own eyes: 
In part, the Soviet soldiers seemed foreign to East Europeans because they seemed so suspicious of Eastern Europeans, and because they appeared so shocked by the material wealth of Eastern Europe. Since the time of the revolution, Russians had been told of the poverty, unemployment and misery of capitalism, and about the superiority of their own system. But even upon entering eastern Poland, at that time one of the poorest parts of Europe, they found ordinary peasants who owned several chickens, a couple of cows and more than one change of clothes. They found small country towns with stone churches, cobbled streets and people riding bicycles, which were then still unknown in most of Russia. They found farms equipped with solid barns, and crops planted in neat rows. These were scenes of abundance by comparison with the desperate poverty, the muddy roads and the tiny wooden cottages of rural Russia. (Applebaum 2012, 26-27)

The Derridean trace of absolute past always haunts the present. Once again, particularly after the invasion of Czechoslovakia by the Warsaw pact countries in 1968 , the whole world would prove itself to be ignorant of what was happening behind the iron curtain: "Chamberlain declares: 'How horrible, fantastic, incredible it is that we should be digging trenches and trying on gas masks here because of a quarrel in a far-away country between people of whom we know nothing'" (Binet 2013, Section 63). The betrayal of Czechoslovakia by England and France, which led to the Munich Treaty, for example, has left its trace upon the world population whose lives were affected by the Cold War. The victimisation of Czechoslovakia remains an inerasable trace in history.

Returning to the concept of the "spectre," Derrida explains: "As in Hamlet, the Prince of a rotten State, everything begins by the apparition of a spectre. More precisely by the waiting for this apparition. The anticipation is at once impatient, anxious, and fascinated: this, the thing ('this thing') will end up coming" (Derrida 2006, 2). Binet's $H H h H$ foreshadows or "awaits" the apparition of power shifts which would eventually, and most symbolically, take place at the Prague Castle. In the time of the Nazi occupation, the newly crowned king was Heydrich. Likewise, in the time of the Soviet occupation, the castle became the seat of the Communist head of state. Power changes hands, but the spectre of the "trappings of power" remains:

There is no proof that Heydrich really did put the crown on his head. I think people wanted to believe this story because it suggested, retrospectively, an act of hubris that could not go unpunished. But I doubt whether Heydrich suddenly believed himself to be in the middle of a Wagnerian opera. As evidence, I offer the fact that Heydrich handed three of the seven keys back to Hácha: a show of friendship designed to give the illusion that the Germans were prepared to share the government of the country with the Czechs. An empty symbolic gesture, to be sure, but the halfhearted nature of this exchange means that the scene loses its potential outrageousness. 
I don't believe he put the crown on his head, because we're not in a Charlie Chaplin film, but I'm equally sure that he did pick up the sceptre-to weigh it casually in his hand. A less demonstrative gesture, but symbolic all the same. And Heydrich, though pragmatic, also had a pronounced taste for the trappings of power. (Binet 2013, Section 133)

The spectre of historical anticipation can be found in Binet's depiction and representation of Edvard Benešs musings. The Czechoslovak independence movement sought to balance out the power of the Nazi and Soviet regimes, appeasing them equally, to save the fate of a small and powerless country:

With anthropoid, Beneš is attempting a great coup to impress these two European giants. London has given logistical backing and collaborated closely. But Beneš has to be careful not to offend the Russians' pride: that's why he has decided to inform Moscow of the launch of the operation. So the pressure is now at its height: Churchill and Stalin are waiting. The future of Czechoslovakia is in their hands; best not disappoint them. Above all, if it's the Red Army that liberates his country, Beneš wants Stalin to regard him as a credible representative-all the more so given his fears of the Czech Communists' influence. (Binet 2013, Section 140)

In my view, Laurent Binet's "infranovel" might at first blush promise to deliver a story of Operation Anthropoid with Reinhard Heydrich, Jozef Gabčík and Jan Kubiš as main characters. However, as readers are taken to the "infra" level of the text, $\mathrm{HHhH}$ is more a novel about a novel based on history. By revealing the techniques of historical fiction writing, a writer's dilemma and anxiety in preparing for and in writing this book, Binet successfully takes part in the history of dissidence. His work reflects a postmodern resistance against grand narratives or metanarratives as well as against mainstream conceptualisations of history, journalism, and fiction writing:

Everyone finds it normal, fudging reality to make a screenplay more dramatic, or adding coherence to the narrative of a character whose real path probably included too many random ups and downs, insufficiently loaded with significance. It's because of people like that forever messing with historical truth just to sell their stories, that an old friend, familiar with all these fictional genres and therefore fatally accustomed to these processes of glib falsification, can say to me in innocent surprise: 'oh, really, it's not invented?'

No, it's not invented! What would be the point of 'inventing' Nazism? (Binet 2013, Section 40)

The historical "infranovel" that is Laurent Binet's $\mathrm{HHhH}$ can be read as a necessary metafictional "invention," which, through its conscious fictionality based on facts and the writer's life, sheds light not only on the concept of history and 
historical writing, but also on the politics and "doubleness" of dissidence. Dissidence, like literature itself, can be read as Plato's "pharmakon" in Phaedrus-the poison of as well as the antidote to violence. Depending on interpretation and allocation of meaning, an act of dissident can be seen simultaneously as both an act of violence and an act against violence. Though Operation Anthropoid was part of the Czechoslovak government-in-exile's attempt to fight against the Nazi regime, it was nevertheless an assassination operation which poisonously bred many more acts of violence. It is only through re(-)membering, as in recounting (hi)story and assembling the fragments of lives lived and lost, as well as regained in fiction, that an act of dissidence becomes a healing "pharmakon" - an antidote against the violence of collective oblivion. A literary revision and re-evaluation of dissent propels readers to imagine and, through imagining, render justice to the subaltern-who are the silent/silenced movers and shakers of the past, of which consequences are relevant to the present day and even to the future. To rethink history and the history of dissidence in a particular time and place-to engage it critically-leads to the revelation that history, as well as literature, belongs to everyone. Though Laurent Binet struggles with the thought that he is writing from the point of view of the excluded "other," who is not directly related to Czechoslovakia and Operation Anthropoid, his historical "infranovel" nevertheless reveals that he, as well as readers of his book, is inevitably both a spectator of and a participant in the haunting trace and spectre of history. The stone of dissidence, which had been cast into a pond a long time ago, sent out ripples of unexpected consequence across oceans. The intimate bond between the writer, the semi-real-life characters who left their concrete legacies, and those who could only leave small imprints on the mud of constant change establishes and fortifies the hopeful notion that political resistance and acts of dissidence are not only transnational, but also transtemporal. Operation Anthropoid is an incident which still bears resonance in the twenty-first century. This (hi)story of defiance, along with its dire consequence, has transcended the spectre that was Czechoslovakia (a state non-existent in the present day). It has travelled beyond Central Europe to the rest of the world.

This is for everyone to re(-)member.

\section{References}

Applebaum, Anne. 2012. Iron Curtain: The Crushing of Eastern Europe 1944-1956. London: Penguin Books.

Binet, Laurent. 2013. HHhH. London: Vintage. 
Calic, Edouard. 1985. Reinhard Heydrich: The Chilling Story of the Man who Masterminded the Nazi Death Camps. Trans. Lowell Bair. New York: William Morrow \& Company.

Derrida, Jacques. 2006. Specters of Marx: The State of the Debt, the Work of Mourning and the New International. Trans. Peggy Kamuf. London: Routledge Classics.

Derrida, Jacques. 1997. Of Grammatology. Trans. Gayatri Chakravorty Spivak. Baltimore: Johns Hopkins University Press.

du Toit, Angélique. 2011. "Grand Narrative, Metanarrative." In The Lyotard Dictionary, ed. Stuart Sim, 86-89. Edinburgh: Edinburgh University Press.

Frommer, Benjamin. 2005. National Cleansing: Retribution against Nazi Collaborators in Postwar Czechoslovakia. Cambridge: Cambridge University Press.

Jameson, Fredric. 1985. "Foreword." In The Postmodern Condition: A Report on Knowledge, trans. Geoff Bennington and Brian Massumi, vi-xxi. Manchester: Manchester University Press.

Lindbladh, Johanna. 2003. "Introduction." In The Poetics of Memory in PostTotalitarian Narration, ed. Johanna Lindbladh, 5-13. Lund: Centre for European Studies.

Lyotard, Jean-François. 1985. The Postmodern Condition: A Report on Knowledge. Trans. Geoff Bennington and Brian Massumi. Manchester: Manchester University Press.

Mastný, Vojtěch. 1971. The Czechs under Nazi Rule: The Failure of National Resistance, 1939-1942. East Central European Studies of Columbia University. New York; London: Columbia University Press.

Shaw, Harry E. 1983. The Forms of Historical Fiction: Sir Walter Scott and His Successors. Ithaca, NY: Cornell University Press.

Spivak, Gayatri Chakravorty. 2010. “Can the Subaltern Speak?” In Can the Subaltern Speak?: Reflections on the History of an Idea, ed. Rosalind C. Morris, 21-78. New York: Columbia University Press.

White, Hayden. 1973. Metahistory: The Historical Imagination in NineteenthCentury Europe. Baltimore: Johns Hopkins University Press.

Wiener, Jan G. 1969. The Assassination of Heydrich. New York: Grossman Publishers. 



\title{
Ben Dorfman
}

\section{Intellectuals and Dissent: Dennis Rodman, Memory Refractor}

\begin{abstract}
This piece addresses the strange case of Dennis Rodman in North Korea-a case bending and blending memories of Cold War ideologies and conflicts as well as revealing a secret yearning for intellectual figures and ideas we somehow simultaneously eschew. Subtly, we connect the intellectual with dissent; the sharp edges of critique with the sage. That's at the same time we often say sages are the last thing we want. All of it becomes a strange cocktail when mixed with the wanderings of a wayward basketball star to and from the communist kingdom of North Korea.
\end{abstract}

Intellectuals have never had an easy time of it. Of course, there's the angst associated with being one. An intellectual, wrote Albert Camus at a date of which I'm not precisely sure (in Grayling 2004, 84), is “someone whose mind watches itself." It's a torturous process, that-the self-doubt, the inner interrogation, the fact-checking, the questioning of one's what one knows and what one doesn't, the search for new horizons; on and on, one might say, with angst and self-torture. Some years after Camus' death, the philosophers Gilles Deleuze and Félix Guattari (1972) argued that knowledge is in fact schizophrenia. Knowledge is a machine constructed of contrasting parts-parts in conflict with themselves. Perhaps they described the intellectual as well. "Smart" men and women may be machines working against their own purposes. At least, I've been told, some feel that's the case.

Intellectuals haven't only been victims of self-inflicted ennui, however. Lack of social and political acceptance has plagued the intellectual as well. Sometime after the Peloponnesian Wars (431-404 BC), e.g.- - a portentous event in Western history-Socrates was forced to eat hemlock. That was for "corrupting" the youth of Athens. Ah; thinking for oneself. Not worshiping the gods. Questioning accepted truth - that kind of thing. It's ironic-Socrates, via his student Plato, would father much of the Western tradition. It's perhaps the ultimate example of being misunderstood in one's own time. That's as the test of one's "own times" might be "all times"-larger acceptances of sets of ideas whose power isn't comprehended in the era from which they come, yet return to define that era at any rate.

Still, we do celebrate intellectuals. Regularly. At least today. Every Nobel Prize is a fête of a "great minds." MacArthur Genius Grants, Man Booker Prizes, grants from the National Endowment for the Humanities and Arts are all celebrations of educated elites (Zuckerman 1996). Every proclamation that scientists have 
provided a "breakthrough" or social thought has achieved "new paradigms" is an ode to rarified thought (I derive my vocabulary of "new paradigms" from Thomas Kuhn $[1962,19]$ - a paradigm shift is when "one conceptual worldview is replaced by another"). In seminal work in the 1970 s and 1980s, sociologist Pierre Bourdieu (1986; 1993) claimed we work on the field of "cultural production." We create legitimacy. We look for currency. We build social and economic systems to get it (i.e., wealth can concern cachet as much as money). It seems, anyway, Bourdieu might well have been right. ${ }^{1}$

Still, recent years haven't always been kind to intellectuals. The 1970s, e.g., featured attacks on "master thinkers." "Master thinkers," claimed the philosopher André Glucksmann (1980, 189), wanted to be "everything." "Master thinkers" sought a "bird's-eye" view of the world - unique insight into truth. "Master thinkers" (a code word for intellectuals) were "metaphysicians"-alchemists of the mind. The "intelligentsia" thought "destinies" for "humankind;" they made proclamations about how humanity has been and where it should go ("salvational expectation" and "millennial prediction" is how one scholar [Koselleck 2004, 21] has phrased it). We've heard this before. Strongmen like Hitler and Stalin often spoke that way-that humanity had a single "place" where it was supposed to "arrive." One needn't be a 1970s philosophical radical, as Glucksmann was, to imagine we didn't need that kind of thinking anymore.

Still, intellectuals, or at least "intellectualism" (the act of being an intellectual), may not be easily dismissed. In the face of globalization and broad trends towards democracy, the desire to question "experts" has clearly emerged-the dehierachicalization of society, more than one commentator has noted, has opened cultures of "I count too" and "why should we listen to them?" (often associated with the decline of the "public" intellectual [Jacoby 1999; Posner 2003]). Still, but if in secret, we can harbor desires for intellectuals. Like fatty foods or a Henry Miller novels in the '50s, we can want them, consume them and look at them but not want to admit to others that we do. Of course, some eat cheeseburgers and read Tropic of Cancer in public. The president of the European Commission, e.g., Manuel Barroso, recently called on intellectuals to come together to form a new "European Narrative" (see Deventer et. al. 2013). It was time to re-embrace the high culture and the Enlightenment heritages for which Europe is well-known. Again, we're flooded with information about book awards, Nobel Prizes, Kennedy Center Honors and new members of the Ordre des Arts et des Lettres (the French

1 Again, the idea, in essence, was that prestige is a kind of social currency as well; one needn't always have money to get far. See Schwarz (2012). 
order of culture) designed to tell us who the "smart" among us are. That's while such attitudes can also be received as humbug. Intellectuals are "eggheads," a journalist once proclaimed (see Halliwell 2007, 21). The "educated" among us simply talk against common sense.

I'd like to show that we love fat and light porn novels. I.e., despite the antiintellectual tenor of many modern societies, we crave intellectualism anyway. My case in point is Dennis Rodman in North Korea. The American basketball star visited the isolated communist monarchy in 2013 together with the exhibition basketball team the Harlem Globetrotters-for non-sports fans, a legendary group of trick basketball players with a history extending back to the 1920s. Rodman, for better or worse, was reviled for the act. A lot of fingers were pointed his way in a few days of furor. Why, though? Why the anger at a sports star (also famous for his colored hair, dating of Madonna and cross-dressing [he wore make-up and a boa at the release of his autobiography Bad as I Wanna Be (1996)]) for doing something off the beaten path; a well-timed publicity stunt, as such? The answer, I think, is that we wanted more. We wanted an "intellectual." For better or worse, that was to tell us where we're supposed to "go."

Now, I'd cringe if I I'm forced to say where intellectuals come from. Again, Socrates was one, wherein the onus seems to fall on ancient Greece. "My good Crito," Plato $(1981,47)$ wrote Socrates as having said in of one of the dialogues around the time of his trial, "why should we care so much for what the majority think?" "The good life" and the "just" were just so much more important. The seeds of independent thought were planted early. "Love of wisdom," as the translation of "philosophy" goes, had a lot to do with critical investigation. A pattern of critical thought emerged at a time when democracy was developing as a state form and the Acropolis' Parthenon was a relatively new building. There should be an edge and introspection to the intellectual way.

Voltaire $(1977,162)$ wrote about intellectuals as well- "men of letters," he called them in his Philosophical Dictionary (1768), a centerpiece of the Enlightenment period in which he argued that intellectuals were "isolated writers." Solitary scholarship was the way to go; pensiveness should trump passion, and the loudmouths of public debate. The irony, of course, was that Voltaire was such a loudmouth. At least one might construe him to be. The French king Louis XV banned Voltaire from the French capital of Paris, e.g. for seditious writings; the Swiss kicked him out of Geneva for speaking against Calvinism. When he died in 1778, the Church didn't want Voltaire on consecrated ground for his anti-Catholic attitudes. 
Whether speaking against religions or monarchs, Voltaire was hardly the picture of quietude he himself seemed to advocate. In the end, Voltaire may have been the ultimate gadfly (see Žižek 2008; Davidson 2010)_a Mercutio whose wit had a razor sharp edge.

The big wind-up for the term "intellectual," however, may have come with the 1894-1906 Dreyfus Affair. L'Affaire, as the French simply call it, was a turning point in European history. It brought up issues of anti-Semitism, nationalism and interstate competition between Europe's major powers (Begley 2009). It interrogated the traditions of "enlightenment," asking how, in fact, enlightened they were. In 1894, the French army captain Alfred Dreyfus, of Jewish descent, was accused of pilfering military secrets for the Germans. It was clear the evidence against him was trumped up. It was found that Ferdinand Esterhazy was the real perpetrator of the espionage-Esterhazy being a descendent of a prominent military family and supported by the establishment (it was easier to have a Jew, qua European outsider, as the fall guy). The government remained entrenched. They refused to release Dreyfus. Esterhazy should be tried. He was-yet acquitted. Scandal reigned. Dreyfus was imprisoned and forced into retirement. After four years of confinement off the French Guianese coast on Devil's Island, supporters were optimistic Dreyfus would be acquitted too. He wasn't. Dreyfusards (Dreyfus supporters) demonstrated in the streets. Anti-Dreyfusards (often anti-Semites) did as well. The "intellectuals" sided with Dreyfus. Those wondering about intellectuals did not. "The Manifesto of the Intellectuals" - a document calling to reopen Dreyfus' case-was signed by a range of famous French minds (Émil Zola, Marcel Proust, Claude Monet and Émil Durkheim among them). Just a day or two before, Zola wrote J'accuse! - one of the great invectives against injustice and government corruption in modern times. The trial against Dreyfus, wrote the French author (Zola 1998, 45), was a "nightmare" for those who "knew its details." It was plain as day for those with critical minds that injustice had been done. There should be a "movement of opinion" against malfeasance, one critic wrote (in Winock 1997, 26). Zola got his movement-the mobilization of "the mind" in the service of larger humanity (on the Affair generally, see Derfler 2002). Those who opposed Zola saw the rise of intellectuals as a political force.

Now, Dreyfus was vindicated. By 1906, he was, in fact, reinstated to his captaincy in the French Army-a victory, it seemed, for the forces of inquiry and right. The after effects were precisely to bind those ideas, however- "inquiry" and "right." The Dreyfus Affair put intellectuals-the "educated" and "insightful"firmly on the side of politics. The intellectual's job was to "enlighten" in the name of "humble people" (Zola 1998, 42). It was a deeply moral charge for specialized 
class-a historical one, if one will. The "emancipation" of "humankind," in Zola's phrasing $(1998,43)$, was the point. It was a goal to be achieved if not exactly through any means necessary - it's hard to say what kind of protest Zola wantedthan at least through the senses of moral outrage one had at one's disposal.

Some agreed. The Marxist Antonio Gramsci $(1971,5,9)$ - one of the founders of the Italian Communist Party-wasn't wild about intellectuals only as artists, scientists and university professors. Intellectuals like Zola's were to be appreciated; encouraged. However, only coming from the educated classes, intellectuals were a bit bourgeois; they bordered to close to the "traditional intellectual" that served landed interests (Gramsci 1971, 452). Gramsci did, however, like the notion of the intellectual's activism. "Organic intellectuals" were what Gramsci soughtintellectuals as an "elaboration" of the "political field." The "political field" meant class conflict-workers against capital. "All men are intellectuals," wrote Gramsci. We needed to realize that. The problem was that we hadn't ascribed all men the "function" of intellectuals. Gramsci took Zola's paradigm one step further and made it yet more revolutionary.

Writer Julian Benda was unsure about this. Benda was an early twentieth century critic-little remembered, for better or worse, except for a book entitled Les Trahison des Clercs (1927; The Treason of the Intellectuals). The basis for Benda's reputation, however, came through indicting if not precisely the politicism of Zola and Gramsci-he was personally on the political left (Müller 2006) — than at least through questioning the worth of "politicized" intellectualism. "If we mention Mommsen, Treitschke, Ostwald, Brunetière, Barrès, Lemaître, Péguy, Maurras, d'Annunzio [or] Kipling [important figures in early twentieth century intellectual culture]" Benda wrote, "we have to admit the 'clerks' [Benda's term for 'intellectual'] now exercise political passions with all the characteristics of passion-the tendency to action, the thirst for immediate results, the exclusive preoccupation with the desired end, the scorn for argument, the excess, the hatred, the fixed idea" (Benda 2007, 46). Benda took a Voltaire-esque approach—truth, not politics, was the intellectual's domain (though, again, there's irony there given Voltaire's own anti-establishmentarian bent [Ozouf 1989]). The intellectual, Benda $(2007,42)$ wrote, is "all those whose activity...is not the pursuit of practical aims." Intellectualism sought truth for its own sake. Social change and political upheaval was for another time and place.

Now, the later twentieth century-with its global conflicts, conceptualization of political systems, mass media and competition between economic views-made such issues complex. Perhaps the two greatest intellectual stars of the post-War era, Jean-Paul Sartre and Simon de Beauvoir (I'm picking and choosing here 
for the sake of brevity [though see Judt 2011]) were of the Zola-Gramsci mold: political, "engaged" (a popular Sartrean term [see Martin 2000; also Pihlainen's article in this volume]) and concerned with "humanity." "Why does one write," Sartre (1993a, 331) asked in 1947? Were we looking for "abject passivity?" Did we seek "art for art's sake"-saying to say, and but mold statements we wanted to make? Should we just "reflect?" In a war, Sartre (1993a, 65) wrote, "there are no innocent victims." Humanity was in decided struggle - a struggle for its own future. Humankind could maintain the status quo. That was largely oppression and fear-the "anguish" of "nothingness," as Sartre (1993b, 12) phrased it. Or, was it an anguish that could be transformed? For many of the time-Sartre, de Beauvoir, Albert Camus, the philosopher Maurice Merleau-Ponty (though there were disagreements about how) - change was the point. It was to "act upon things," as Sartre (1993b, 67) phrased it; to "change" the world, as Marx and Engels $(1993,62)$ once phrased it. Intellectualism-thought and introspection-was an activity through which one sought to liberate oneself as well as the lives of others. That was by way of turning principle in to action.

Still, "principle into action" had its pitfalls. Again, I'm being brief. However, it was a noticeable affair when Sartre and de Beauvoir-more than a few European intellectuals, in fact-failed to denounce Stalin (the French Communist Party at-large managed to avoid this as well). ${ }^{2}$ In the name of social change, many intellectuals and the political organs to which they attached themselves, even as fellow travelers, failed to distance themselves from dubious systemstotalitarian ideologies whose potentially benign principles had nonetheless deleterious results (Tony Judt $[2011,156]$ notes that the fact that many intellectuocommunists seemed to deny the existence of Soviet crimes was sometimes even held forward as a redeeming naiveté of the communist; the better nature of

2 Sartre was never a member of the French Communist Party-an organization deeply criticized for the period of its pro-Stalinist stance. This is important detail. What I'm pointing to, however, à la Judt, is that the left often had complex positions to negotiate. How much could and did one step back from the project of "really existing socialism," as it was often phrased (socialism or communism in practice), before one abandoned the entire idea? Even by relative apologists for Sartre-those pointing out that he maintained a highly nuanced and often critical relation with the Stalin-lead Soviet regime (e.g., Birchall 2004)-it's noted that the distancing was hardly complete. Indeed, there were more than a few strange attempt to provide a particular logic for Stalinism (including in writing) and for a short time in the early ' 50 s, there was a clear rapprochement with the pro-Stalinist French Communist Party. Between the USSR's invasions of Hungary and Czechoslovakia, though (1956 and 1968), this would eventually change. 
his or her intellectual reflection). Politics became the "opium" of intellectuals, Raymond Aron $(1962,155)$ argued. Now, the problem wasn't just Marxism. It was the belief in any predetermined end (setting up a Glucksmann-esque critique). History became an "abstract ideal"-a "must." Imperative overcame possibility. Determined insistences on liberty, argued Aron and others (Karl Popper [1957] offered a similar critique), weren't necessarily wrong. Overweening combinations of intellectualism and political messianism could nonetheless diminish our possibilities as much as open them. It could tell us what was right rather than allowing us to find out for ourselves-or even investigating thoroughly, or letting history show, whether or not it in fact was.

Now, some (many, perhaps) embraced intellectualism from the left. Positions of Marxism, socialism and liberal democracy were often de rigueur. Zola freespeechism, Marxist-Gramscist intellectual "organicism" and other attempts, no matter how consistent or confused, to speak of liberational historical processes formed a continuum many expected to go together-that "educated minds" had predilections for cosmopolitan emancipation and egalitarian universalisms that but found expression in different ways. Some did, however, approach intellectualism from the right. The German philosopher Martin Heidegger, e.g. at least for a time, embraced National Socialism. For at least a year as Rector of Germany's Freiburg University, Heidegger sought the favor of Nazis. After the War, justifications for his views were vague and unapologetic; he wore the regalia and spoke of the "self-assertion" of German knowledge. He sought a "new era," claimed Heidegger $(2010,48)$ in a 1966 interview with German magazine Der Spiegel, in which a new sense of knowledge's "use" by the nation was necessary to overcome the "technical organization" of Western society-a "technical organization" Heidegger claimed to be "inauthentic" (it manifested itself in what he called "planetary technology," or global over-rationalization). The real non-conformist intellectual accepted no cosmopolitan shibboleth as but "right." He or she had the right to deconstruct knowledge in other ways and towards other conclusions-e.g., the value of the parochial, the national, peoples and more "organic" levels of experience that were part of Nazi ideology. ${ }^{3}$ Again, complexities abound. Heidegger didn't personally promote death camps. He didn't persecute Jews himself (it's at least not clear he did). He resigned as Rector of Freiburg in 1934-early in the

3 Social Darwinism and "biological nationalism"-some sense of the evolution of naturally and archaically distinct peoples-C.M. Vasey (2006) has noted, are the roots of National Socialist ideology (over and above anti-Semitism). These, as such, were linked via blends of theories of tradition and supposedly "indisputable" facts of the natural world and historical cycles. 
Nazis' dominance in Germany. He didn’t say "no," however. He didn't speak out. ${ }^{4}$ Neither did intellectuals such as the conductors Herbert von Karajan or Wilhelm Furtwängler. Small protests such as speaking against the firing of Jewish colleagues (something Furtwängler did do in his time as conductor of the Berlin Philharmonic) did not change the larger course of events (Shirakawa 1992). Mealy-mouthed protest in the face of a sea of death and despair was but a small drop of opposition in an ocean of overt tragedy.

It was here figures like Glucksmann $(1980,199)$ intervened. Intellectualism left or right was, somehow, "theory" against reality. It was forcing "predicates" behind all things-that one sensed one was analytically right, and that meant driving principle home as the raison dêtre behind all things. This deserved to be questioned. Perhaps, in fact, what one found was that "master thinking" wasn't master thinking at all. Perhaps (a touch like Bourdieu, but not exactly) it was just bare toadying. I'll shift to Glucksmann's contemporary, Michel Foucault, for a moment. The intellectual, Foucault $(1980,132)$ wrote, may not be the "bearer of universal values." The intellectual may not operate outside power, decided interests or one's own urge to position oneself in particular ways. Intellectuals may not have insights into "truth" - "genius" realizations emerging from "rarified minds" knowing better than others. Rather, intellectuals may "occupy...specific position[s]." They may do things in relation to social norms larger than themselves, sometimes even by opposing them, that contribute to the "general functioning of the apparatus of truth"

4 Heidegger's relationship with Nazism has been a highly significant point of debatelargely due to Heidegger's almost universally agreed upon status as one of the handful of most important philosophers of the twentieth century (his emphasis on being, as opposed to knowledge, as well as his particular mode of describing being, represented major innovations). Figures such as Victor Farías (1989) have laid out an active role for Heidegger. Again, it was largely from the locale of the university-not, perhaps, the center of the wheel of national politics Some care needs to be taken, however. After his resignation as Rector at Freiburg, Heidegger did not come out in obvious support of the movement as in the single year of his rectorate and, in fact, he wasn't always viewed positively by the oft-lesser philosophers clearly ingratiating themselves with the Nazis (that leaving all issues of the precise way in which his philosophy may or may not have related to Nazism aside). Ultimately, I'd side with Tom Rockmore here: Heidegger's insensitivity and intransigence on the issue of relating to Nazism, both during and after the Nazi period, is astounding given what was known as to what was going on, and what happened. As Rockmore $(1992,241)$ writes, "Heidegger, who is sensitive to being, is startlingly insensitive to human being." His philosophical observations may have been genius. They were nonetheless connected to and sometimes used to support, perhaps the most beastly set of ideas in the modern age. 
embodied in those norms. Intellectuals may serve if not agendas and interests, then "orders" of knowledge (Foucault 1994). Intellectuals are burdened with the same blinders as all of us - the same tools to formulate their ideas. Not unlike Gramsci, what may be different is the role.- an intellectual is a matter of who we ascribe as such more than anything anyone "is." It's not that some-important people-don't occupy the role. But again, at work is a sense of who's important and who's not. In part-though it's hardly all of Foucault's thesis-it's us who do the ascription. ${ }^{5}$

In general, I'm on board with this idea. Intellectuals have historically come in many shapes and sizes. They appear as writers, artists, journalists and politicians. They are activists and professors, conductors, painters and occasionally self-made men and women breaking into the world of "ideas." Intellectuals might be "unattached" (Mannheim 1968, 140), posing themselves Benda-esque among society's "mutually conflicting forces," offering insight but not decided political ends. They can be committed-Dreyfusards, activists, free speech advocates and raisers of consciousness. They can form revolutionary "vanguards," winning the day for "progress." They can do the opposite as well: opposing revolutions, or supporting those we don't like (National Socialism, for example). Two things seem to be salient, however. Quoting one recent book (Falk 2003, xx), when it comes to the intellectual, "ideas matter." We conceive, somehow, that intellectuals are involved with ideas: that theory, insight and learnedness are the intellectual's terrain. We imagine that they look for futures by studying the past, and because of their erudition, they might be able to tell us what those futures might be. We see them, somehow, as involved with "salvational expectation" and "millenial prediction" (again, Koselleck 2004, 21). That, however, is another point: that that's something that we do; that "philosopher kings" (Falk 2003a, 1) is something we look for; that we elevate the "rumpled-looking" (rumpled because of all the thinking) to "leadership" roles. Now, as far as kingship is concerned, people have a diversity of places to which they wish to be led. Destiny is not a single place; many groups have different leaders and many intellectuals take the head. Many have different concepts about what the idea of leadership means (see Falk in this volume). It is darn interesting that it

5 Largely, Foucault suggests our ascriptions of the social world are made before we get there; they exist, in his view, in "orders of discourse," or "codes" of knowledge (Foucault 1994, xx). Still, we participate the in the functioning of those orders. Power structures are reproduced via the participation of the actors involved. Again, that isn't by "will" in a traditional sense. It's not a deliberate and "thought through" choice. Those orders and the subjects within them-and the value of their actions in that context-are nonetheless deeply intertwined. Social ascriptions wouldn't exist if we didn't participate in their historical life. 
happens, though; it's darn interesting that the ideas, even of the "solitary writer," should concern where we should go. I'll turn to Noam Chomsky (in Samuels 2012) for a moment. As he notes from his own intellectual position, it'd be a stretch to say intellectuals are "beautiful." They're obtuse and do many strange, and sometimes regrettable, things. From time to time, however, we deem, or at least it seems we have deemed, them necessary. That's for their ideas. Again, somehow, that's because those ideas are supposed to tell us where to "go."

$$
* * *
$$

\section{How to discuss l'Affaire Rodman?}

We perhaps might go back in time. The Democratic People's Republic of North Korea was founded in 1948. It was, like so many things in the late 1940s, a result of the Second World War. The Korean peninsula, occupied by Japan since 1895, was divided between the Americans and the Soviets after its 1945 liberation. A pro-American regime was installed in the South (Syngman Rhee's) declaring statehood in May 1948. The North, headed by the Soviet trained Kim Il-Sung, declared statehood in September that year. It was an adversarial act. There were controversies about elections throughout the peninsula, neither regime qualified as anything near "democratic" and it's hard to say if any of the powers behind the two Koreas were interested in democracy as opposed to power in the first place. In any case, war broke out between the two states in 1950. It was a bloody war-back and forth, costing thousands and thousands and thousands of lives (it was also the first UN based international action [Haruki 2014]). After a few years of here and there-involving everyone from the Koreans to the Americans to the Chinese-the republics ended essentially back where they started: with an armistice declared along the $38^{\text {th }}$ parallel. As many know, the two countries are officially at war to this day. Tensions flare up from time to time as peace has never been declared between the two states.

As the country is often singled out as bizarre, many have a sense that North Korea became something of a hereditary socialist monarchy. One author has called it a "paranoid state" (French 2007) and it's a description that fits. The state maintains its own stripe of communist ideology called Juché (self-reliance, more or less [Suh 2013]), and it maintains an unparalleled cult of personality around its rulers: Kim Il-Sung, Kim Jong-Il and the current Kim Jong-Un (the "Great Leader," "Dear Leader" and "Outstanding Leader," respectively). Its rulers are hereditarybizarre, as communism is supposed to be anything but (the Soviets executed the Russian royal family in 1918 in the name of plebian de-hierarchicalization, e.g.). 
North Korea isolates itself almost as fully as anyone can in today's world. It allows little journalistic access; there are documentaries, but the construction of virtually all journalism addressing the country surrounds how hard information is to get. ${ }^{6}$ The "Peoples' Republic," as it monikers itself, allows virtually no Internet access and maintains an Orwellian state media in which it's rumored that radios in Pyongyang apartments can be turned down but not off. The state surveilles its citizens (extensively) and few consumer goods from the West are allowed to come in. The deaths of the "Great Leader" (Il-Sung) and the "Dear Leader" (Jong-Il) provided the modern world with some of its greatest examples of internationallybroadcast mass hysteria. I'm not sure what North Korean television news said when Jong-Il died. I haven't been able to find it. When Il-Sung died, however, it was announced that "thousands of cranes descended to fetch him" (Tetteroo and Feddema 2001). Tens if not hundreds of thousands of Pyongyang residents wept, threw themselves on the ground and went into near conniption as they thought about the birds removing from the earth their departed leader's soul.

Now, it's after Jong-Il's death (2011 [which also included popular near conniption; I'm just not sure how much]) that the Rodman case takes off. There was secession intrigue at the end of that year-that when it was clear that Jong-Il was on his death bed. It seemed more than one dauphin was on hand. One potential inheritor was Kim Jong-Nam-Jong-Il's eldest son. Via the usual rules of inheritance, it would seem he would be the automatic choice-the right hand son taking the reins from the father. Authorities caught Jong-Nam using a false passport to visit Disneyland in Tokyo, however (see BBC 2001), bringing that plan to an end. Kim Jong-Chul, also older than the Jong-Un who would eventually accede, was another possibility. For reasons that aren't totally clear, however, he was passed over too. The family's former Japanese chef claims less than convivial relations between father and son as the reason (Sang-Hun and Fackler 2009). That left Jong-Un. He is, it seems, an enigma. Little is known about him personally. Policy-wise, where we can know something, little has changed. North Korea's economy has opened but the smallest amounts. There are propaganda films of him gesturing slightly towards Western consumerism patterns, but movement on the economic front has been slow, to say the least (French 2015). The extensive gulag system instituted by both the father and grandfather remains intact. Travel to the country remains as difficult as ever. The country's nuclear program remains in full swing (though it sometimes has difficulty getting test missiles off the ground [BBC 2012]). Jong-Un continues the

6 For some of the documentary work done on North Korea, see Tetteroo and Feddema (2001); Vice (2008); Vice (2013); Frontline (2014). 
"military first" politics that hallmarked his father's regime. The country declared in 2013 that it didn't see itself as bound by the terms of the 1953 armistice treaty. This was a frightening prospect for people aware of the tensions along what is generally recognized as the world's most heavily militarized border (see New York Times 2013; Park and Snyder 2013).

What does appear to be the case, however, is that the man is a basketball fan. It seems few pictures exist of the Jong-Un previous to his ascension. It's speculated that he went to boarding school in Switzerland. Perhaps he did. If he did, it was under a false name. Again, if he did, he might have also been photographed. One of the photographs that appears to be Jong-Un (though there's controversy over whether or not it's actually him) features a young Korean man on a soccer pitch wearing a Chicago Bulls number 91 jersey - the number Dennis Rodman wore during his professional career (CBS 2013a). The stage was set for some fabulously strange doings.

Now, Rodman himself-an American basketball Hall of Famer-was a star but still second tier player on the Bulls championship teams of the 1990s. The star on those teams-perhaps the biggest star in all basketball history-was Michael Jordan. Jong-Un is reputed to have first invited Jordan to come to North Korea. The invitation was declined (Gladstone 2013). Rodman, together with the risqué documentary outfit Vice and the exhibition basketball team the Harlem Globetrotters, said yes. It was a unique, if again extremely bizarre moment, in both basketball and political history.

In a way, that there was precedent for this. In 1971, American table tennis players were the first Americans other than members of the Black Panther Party to visit communist China. It was an opening volley in a range of negotiations eventually culminating in Richard Nixon's 1972 visit to the country-a visit whose effects we still feel today (that through having opened China more internationally). 2013 was different, however. American diplomats-notably members of the Clinton administration - had already visited North Korea. Jimmy Carter visited the country in 1994. China was a force bridging North Korea and the West via its move to a more central place in world markets and politics. In the post-Cold War era, sports were hardly needed as an overture if countries wanted to change their systems. It also has to be said, his fame aside, that Rodman was a distinctly odd choice. Pierced from head to toe and often sporting multi-colored hair, he was the diametric opposite of the staid citizen promoted by the Juché regime. The UK's Daily Mail reports that North Korean men are allowed to choose among one of ten official hairstyles. None of them, it appears, include color (Brady 2013).

Uncanniness aside, on February 26, 2013, Rodman, the Globetrotters and Vice (with backing from the media company HBO) landed in Pyongyang. They were 
greeted by officials. There was much handshaking and back slapping and there were photo ops galore. The entourage-Rodman, Globetrotters and everyone else-took the standard tour of the important monuments of the country's show capital: massive statues of the two previous leaders, captured American warships (one, actually), monumental communist building projects, collectivist farms and other sites testifying to socialist derring do. They stayed in the one hotel open to international tourists and were followed closely in their every move. ${ }^{7}$

Basketball-wise, Rodman and company trained a youth team. They taught them the American tricks of the trade and the free-style form making the American game so popular. They then, of course, watched a game - a fixed affair between North Korean athletes and American players. It resulted in a perhaps predictable tie. During the game, Jong-Un made a "surprise" appearance. He was applauded deafeningly so. Rodman made a short speech. He was applauded (maybe even more deafeningly so-near treason in North Korea). The players-with Rodman at the center of it all-had dinner with the enigmatic leader. They had drinks. They partied. There were more photos. It was a short visit. On March 1, Rodman left the Kims' fiefdom. He returned to the U.S. via China (the only way out for tourists). On his way out, Rodman termed the North Korean leader his "friend;" it had been, he proclaimed, a brotherly hoop fest. It breaks the narrative. However, when he had gone in, Rodman, referring to a hit song from 2012, tweeted that perhaps while on the trip, he'd meet the "Gangnam style dude" (a singer named Psy). Psy had tweeted back "I'm from the SOUTH, man!" (Brzeski 2013). It seems, in fact, that he was.

Now, the reaction unfolded, in fact, both during and after the visit. During the visit-on February $28^{\text {th }}$, to be exact-the U.S. State Department offered passiveaggressive commentary. Asked what he thought about the visit, State Department spokesman Patrick Ventrell offered that the American foreign ministry was not a "clearing house" for private individuals seeking to travel to North Korea. "There are some Americans who go there," the official offered. However, the branch of government concerned with foreign affairs had no further comment (Dewey 2013). It was a hard stare across the Pacific Ocean at the bepierced Rodman as he was chaperoned around Pyongyang. The White House-the home of an intellectuallybedecked Nobel Prize winner-also didn't mention Rodman, but pulled a few less punches. No reference was made to Rodman himself. Jay Carney was terse, however: "Instead of spending money on celebrity sporting events to entertain the elites of that country, the North Korean regime should focus on the well-being

7 All of this can be seen in the Vice (2013) documentary on the Rodman visit. 
of its own people, who have been starved, imprisoned and denied their human rights" (Nakamura 2013). Rodman was within his rights to go. No one but no one in the halls of American government was pleased, however. Then the damn broke. Ranges of talk shows took up the issue; sports commentators all of a sudden became international affairs experts. Experts on international affairs wanted to weigh in on the comings and goings of a sports figure. "I fear he might go over there and start another world war," sports commentator Skip Bayless (ESPN 2013) offered on the popular ESPN network. It was a wrongheaded move that didn't represent the best of the game (whatever that was). CBS' This Morning program offered Rodman's visit as "ridiculous." Anyone with things "in perspective" the show's hosts noted-including former public television profundus Charlie Rose (CBS 2013b) - could see the ludicrosity of what was afoot (Rose guffawed at but the thought of trying to justify Rodman's visit). Rodman wasn't only an American cause célèbre, however. Why, one writer from Germany's Frankfurter Allgemeime Zeitschrift (2013) wondered-one of Germanys leading newspapers-was Rodman in front the international press referring to Jong-Un as a "cool guy?" Why was he violating not only American sensibilities, but those, at least potentially, of a wider liberal world as well? Commentary from Israeli (Bob 2013) to Indian (Spelatnick and Hosenball 2013) to French newspapers (Mesmer 2013) echoed these sentiments. If one stopped and asked, what was the former coéquipier of Michael Jordan doing in the neo-Stalinist state, inquired Le Monde (Mesmer 2013)? Was it a joke, or was it some kind of attempt to engage international affairs? No doubt: the curiosity was largely U.S.-based. International intrigue was also peaked, however, as it was unclear what the basketball player had intended to do.

The pièce de résistance, however, came on the American talk show This Weeka magazine show covering political events. In discussion with Rodman but days after his return stateside, host Georges Stephanopoulos-a Bill Clinton advisor and holder of degrees from Oxford and Columbia - asked Rodman if, in making his trip and referring to Jong-Un as a "friend," he (Rodman) had been aware of "[Jong-Un's] threats to destroy the United States and his regime's horrendous record on human rights." Did Rodman know, Stephanopoulos wondered, about the history of the Kims' dictatorial regime and their totalitarian control of the lives of millions? Did the author of Bad as I Wanna Be know about the gulags, missile tests, anti-American threats and anti-democratic tone? Did Rodman have any awareness of the context in which he operated? Did he have a modicum of social or historical knowledge he might bring to the situation? Was there a logic to what he had done-a principle from which he was working? Could he use any modicum of ideas, rational set of concepts, political worldview or philosophy to explain to us his actions? 
Very simply, he couldn't respond. Rodman fished. Rodman hit upon interpersonal themes. He'd heard about problems, yes. He knew something was wrong in the isolated state so frequently in the news and so distinctly set off from the world around it. He had some awareness of what North Korea was. Not more than anyone else, though. For Rodman, it was a personal trip-a, "sure, why not?" situation. He tried to talk apolitically: maybe Jong-Un and U.S. President Obama could get together-they were, after all, both sports fans. Hoops and baggy shorts might transcend all. Stephanopoulos pressed. He looked annoyed. He raised his eyebrows; he smirked. Rodman tried to say issues had more to do with Jong-Un's father and grandfather than Jong-Un himself. Jong-Un had inherited his dictatorial characteristics. The genes were to blame; it was all a mistake. Stephanopoulos was distinctly unimpressed. One of the well-coiffed and well-spoken members of the Clinton administration served Rodman with a report from Human Rights Watch. He told Rodman about North Korean history-death camps and murders. He regaled the be-Gucci'd ballplayer with tales of abuse and malfeasance. Stephanopoulos suggested that were Rodman to read the report, he would "learn a lot more" were he to return to the country. He then turned to the trip's documentary maker (Vice's Shane Smith) for some "intelligent" discussion.

Stephanopoulos' line echoed over the next several days. "Reckless behavior is not diplomatic," wrote Kori Schake (2013) for The New York Times. The basketball star had been used by a regime that would have jailed him were he one of their own citizens (Rodman's hair, after all, hardly fit the appropriate paradigm). Though some (Cooper 2013) argued that there was a level of legitimacy in celebrity diplomacy, any possible breakthrough that might come in North Korea would be despite Rodman's "naiveté" and "clumsiness." It was the wrong guy to send and we shouldn't think different (of course, he hadn't been sent). Rodman, right in line with title of his autobiography, had been as "bad" as he wanted to be. He was doing what felt right. He hadn't thought, though; he hadn't reasoned. Rodman hadn't moralized or philosophized. Indeed, he had gone even while the North Koreans held an American citizen in custody (Kenneth Bae, for supposed illegal entry into the country to spread propaganda). Rodman, apparently feeling guilty, tweeted that Jong-Un should do him a "solid" and release Bae (Fisher 2013). He nonetheless went back. Since starting to compose this article, that, in fact, was twice.

$* * *$

Clearly, problems depend on how one looks at them. Without a doubt, actions can be problematic in and of themselves. In 1963, e.g., philosopher Hannah Arendt reported on the trial of SS colonel Adolf Eichmann in Jerusalem. Eichmann, 
like many former Nazis, fled to Argentina. He was caught in 1960. In front of an Israeli court, Eichmann attempted to defend his genocidal past by citing both then-current law and the then-present cultural and administrative momentum in Germany. "He did his duty," Arendt $(1963,153)$ noted. He obeyed the norms and expectations provided him. Eichmann wasn't smart; he hadn't particularly good reflective tools. He was "banal" - the everyman. Still, he was culpable. Regardless of intellectual capacity or cultural currents, Arendt suggested (Arendt, ironically enough, being Heidegger's one-time lover), one can think for oneself. One can use one's own judgment. History, argued Arendt, is littered with examples of people choosing to do different (she notably invoked the evacuation of the Jews from Denmark in the latter days of that country's German occupation; an example of decided reflection and courage). That evil might be everyday-that it might be "banal"-was no excuse for engaging in it.

The historian Daniel Goldhagen made not dissimilar arguments in 1997. Attempting to identify Hitler's "willing executioners," Goldhagen argued it was important to not abscond general members of society from responsibility for nihilistic acts manifesting themselves in the worst human violence. "Obfuscating labels like 'Nazis' and 'SS men,'” Goldhagen $(1997,6)$ argued, took responsibility for the Holocaust away from where it lay. Germans perpetrated the killing-ordinary people like one meets every day. He very simply argued that it would be wrong to think otherwise.

Maybe Rodman was a Goldhagen German or an Arendt Eichmann. Perhaps, by legitimizing, recognizing and palling around with the North Korean leader and his regime, he might have supported their crimes. One can't, and never should, downplay how extensive those are. Reports identify tens if not hundreds of thousands in North Korea's prison camps (Human Rights Watch 2014). Free speech has no role in North Korean life; it's the party line or no line at all. According to most measures (e.g., Economist Intelligence Unit 2012), no state maintains a worse record on civil rights. Freedom of thought is an alien concept. There is no right to assemble except in state sanctioned forums. Long story short, the country verges on a total rights travesty. Indeed, an Israeli organization even argued that Rodman has legal culpability. North Korea supported a Japanese terrorist group (the Japanese Red Army) in the 1972 massacre of Israeli citizens at the Lod Airport in Tel Aviv (twenty-six were killed). Rodman supported North Korea. Perhaps Rodman had retroactively sanctioned the massacre of Israelis (Bob 2013).

Now, there are points here. Goldhagen and Arendt may be correct. Society, the "every day," "all of us" - normal people-allow things to happen. Those are sometimes unthinkable. As Foucault $(1979,308)$ once asserted, we often allow "petty 
cruelt[ies]" as we move through space and time. We engage subtle forms of harm that can expand when given the right conditions. No one is excusable from the evil one knows surrounds one or, if one doesn't know evil is there, at least senses that it might be present. One's moral compass may have no right to be turned off.

Culpability is a different matter than reactions, however. Culpability is a different problem than why we reacted-or at least some in the media and public offices reacted-to Rodman in the way that they did. Again: did anyone truly find Rodman culpable in the North Korean regime's rights abuses? Did anyone really think a basketball player-a notoriously flamboyant one at that-was going to provide a morality lesson: that he would be a philosopher of world affairs or historical change? Did we really expect to find Zola- or Sartre-esque protests against injustice-outraged statements about the inviolability of humankind or the nature of universal law? Did we even imagine we'd get a Heideggarian justification of regimes we find repugnant yet perhaps, in some strange way, as part of a rant against capitalism or modernity or some other such concept, one might defend? Did we really expect Voltaire's "isolated writer" - the solitary seeker of truth working quietly by candlelight to discover the secrets of society, politics and humankind; the intrepid pursuer of verisimilitude reflecting on the human essence and its means and ways?

Indeed, it seems, that's exactly what we expected. We looked for Voltaire, Sartre, Heidegger, Furtwängler, Gramsci-someone; someone with a plan. We looked for thoughtful repose and the power of "ideas." Now, I admit: "we" is a tough configuration. The public mind is hard to detect. Especially in the age of globalization, "we" largely functions in the space of what one anthropologist (Appadurai 1990, 299) has termed "mediascapes" and "ideoscapes" - "concatenations" of images, ideas, bits and pieces of commentary and politics swirling through public space. How much of that is us and how much that is the sports networks and George Stephanopouloses of the world is hard to tell. "We" are often "imagined"-societies are driven by intuitive ideals as much as any "reality" (see Anderson 1983). Still, one finds atmospheres. Rhetoric and discourse unfolds. Communications emerge. One "thinks." One "reacts."

The problem lays there. It lays with what's happened to intellectuals not among themselves, but among us. In 1963, the American historian Richard Hofstadter investigated anti-intellectualism in American life. He argued that it had many sources - the fundamentalisms of American religion, business culture, intellectuals' transformation into technocrats (including the retreat into the university [see also Jacoby 1987]); democracy itself. It was once understood, Hofstadter (1963, 145) argued, that leaders “were...intellectuals." Leaders didn't necessarily promote 
themselves as "elite" - "more than" or "superior to" others. They were not necessarily "above" anyone else. That they might have ideas, however-concepts and philosophies-was accepted. That one might think studiously was understood. Indeed, it was sought. Ideas were the "very fabric of the nation," Hofstadter writes. In something nearing an overture to archaic democracy, one shouldn't govern in the absence of ideas. If we weren't all philosopher kings, we needed those who were. We needed those who might communicate and tell us what politics should be and how to transform philosophical truth into justice and principles for social action that would take society where it wanted to go. It was said out loud in the social body that our desire for such things was real.

Again, what changed is hard to say. I don't want to turn this in to an American issue because it's not exclusively. Hofstadter's comments concern the nature of democracy regardless of where it's to be found. As Hofstadter poses it, however, democracy eats itself. It undoes "aristocrats" (Hofstadter 1963, 133). It demands that one think for oneself. Democracy is based precisely on a critical voice towards those above you. It demands an egalitarian spirit; the equality of all. Once that spirit is invoked however, ideas are under threat. That's because ideas are everyone's property-they don't belong to just "some." "Rights," "freedom," "representation," "democracy" and "civic life" were once the property of an elite. They were once discussed in Paris salons and Boston coffee shops-fodder for the visionaries who would form new nations ("philosopher kings"). Transferred from the "kings" to plebeians, however, the concepts of kings were no longer that: the concepts of kings. It's my vocabulary, not Hofstadter's. However, when everyone's a philosopher king, who needs philosophy anymore? So came the levelling of the Western, and perhaps international, political demos.

Still, ideas never left. Concepts had to be there somewhere. The formulations and arguments on which new societies were founded couldn't just disappear because everyone "owned" them. Someone had to stoke the coals and tend the fires as the system was based on critique and probing into the world around one. It was based on the idea that one might not always do as others do, go with what the "majority thinks" (Socrates again) or that one might at least say what one thinks (wherein one has a thought). We were thus left in a dual position. Pray to the intellectuals and one wasn't democratic. One suggested one might know more than others, wherein knowledge might not be the property of all when, by right, it was (i.e., no one "owned" democracy's ideals). To never engage intellectualism, however, meant to risk letting democratic dreams go. It meant perhaps relinquishing the heart of democracy itself: ideas-ideas_-such as equality, the replaceability of officials, the notion that all of us had power (none more than 
others) and the ability to build and critique systems that would capture and reflect these diverse realities. It meant not always saying a complex concept was humbug, and it was only "eggheads" who sought such things. That's again while one had to be very careful with such things. Letting out that desire too much - the desire for intellectualism - could signal that equality was a complex concept; that it wasn't always "come on; they can't know better than you! We're all the same!" If one had to consume a cheeseburger it was best done late at night. That's so that when the family came down in the morning, they'd never know.

To that extent, the issue was us. What we want; our appetites; our desires. Indeed, at least on the part of some commentators-Stephanopoulos was the most obvious though not only example-this issue seems to have been precisely that. Rodman didn't do what we say we don't want, yet really, we do. Rodman didn't torture himself. Rodman didn't reflect on the morality and direction of history. He didn't look to the future or interpret the past. He invoked no academic or cultural lexicon; no specialized knowledge or deep thought. Rodman had no perspective-he was absent intonations on what politics, life or society meant. Indeed, we weren't sure what Rodman was thinking. That's if he was thinking at all. That was our standpoint-that thinking was important, and that at least at the right moment (when we'd like), thought should be turned into political or historical principle. That was, in fact, our standpoint, though: that intellectuals mean something. That's often at the same time that we say that they don't. Somebody hand me Tropic of Capricorn. I'll pretend I'm reading only the "clean" parts.

It feels appropriate to leave off with the issue of dissent and historical memory. A few points emerge. Firstly, intellectualism as it's been characterized here doesn't always involve dissent. Zola, Sartre, de Beauvoir, Voltaire all spoke against the societies around them. They defied authority and lived dangerously in their own times. It was meaningful. Without Zola, Dreyfus might never have been exonerated. Sartre and de Beauvoir contributed to pressures on mid-twentieth social conformities inspiring a generation of counter-culture. Voltaire was a hero of the French Revolution. All contributed to change-driving societies towards new frontiers and challenging systems many saw as wrong.

I want to be careful with Heidegger, von Karajan and Furtwängler. These were not Adolf Eichmanns. They did not actively support the Holocaust (though Heidegger's newly published diaries include some stunning anti-Semitism [Rothman 2014]). Though they offered tacit support to the regime by either speaking at least momentarily on its behalf or remaining within its physical 
spaces when so many fled, they nonetheless did so largely from the insulated domains their prestige-intellectual prestige-allowed them to maintain. One could claim, anyway-claim - this kept them at arm's length from the crimes being perpetrated around them. Furtwängler, of whom one can find films in which he conducts the Berlin Philharmonic in front of Joseph Goebbels and Heinrich Himmler on Hitler's birthday, claimed he remained in Germany to save German music. "It was my intention," Furtwängler argued in front of a de-Nazification court, "prove that art meant more than politics" (Shirakawa 1992). The goal was to save the legacy of Mozart and Beethoven, Brahms and Mahler. I don't doubt that's true. As with Heidegger's philosophy, there's near universal agreement on the aesthetic power of Furtwängler's conducting and the originality of his interpretations. Von Karajan is also near-universally admired for his musical acumen and aesthetic intellect. These were figures serious about their art (see Kater 1999). Still, how far is one from evil when one does live its political, social and geographic space? Is one ever fully isolated from the world around one no matter how august one's position might be? Furtwängler was present while Nazism perpetrated the worst crimes possible. Should he not be held responsible for that? Certainly one wonders the same when one sees photos of Heidegger dressed as a Brown Shirt, and, though he eventually fell from the Nazi party's favor, one can only imagine what von Karajan had to do to climb to the top of German music in the early 1940s.

Still, we look for intellectuals to articulate. We look for them to say. We look for them to explain. We look for intellectuals, as one sociologist (Coser 1965) put it, to be men or women of "ideas": to express the modes of thought we maintain through which we discern right and wrong, past and future, destiny and the wrong way or false step. Even if it was in terms of weak-kneed defenses of why they didn't dissent, figures like Heidegger, von Karajan and Furtwängler were at least able to do that. They could at least say something about why they went with the status quo, evil though it was. Rodman couldn't even muster that. He had no words. He had no framework or lexicon. He had no philosophy to appeal to nor worldview to illustrate. It was problematic. Again, though, I'd pose it as less Rodman's problem than ours. It's our appetite for thought's hidden pleasures, the taste of "ideas" and feeling for senses of the "unique" we had at stake. "Eggheads!" we proclaim, as we watch the work of the sage who would lay out the destiny of humankind. That's while we crack an egg open, butter some toast and prepare ourselves for the breakfast we really want to eat. That's as opposed to the one we're supposed to have when the kids come downstairs. "Intellectuals" indeed... 


\section{References}

Anderson, Benedict. 1983. Imagined Communities: Reflections on the Origins and Spread of Nationalism. London: Verso.

Appadurai, Arjun. 1990. "Disjuncture and Difference in the Global Cultural Economy." Theory, Culture \& Society 7: 295-310.

Arendt, Hannah. 1963. Eichmann in Jerusalem: The Banality of Evil. New York: Penguin.

Aron, Raymond. 1962. The Opium of the Intellectuals. Trans. Terence Kilmartin. New York: Norton.

BBC. 2012. "North Korea Rocket Launch Fails" (April 12). http://www.bbc.com/ news/world-asia-17698438.

BBC. 2001. “Japan Expels N. Korean Leader's Son," May 4. http://news.bbc. co.uk/2/hi/asia-pacific/1310374.stm.

Birchall, Ian H. 2004. Sartre against Stalinism. New York: Berghahn.

Bob, Yonah Jeremy. 2013. "Shurat HaDin vs. Former NBA Star Dennis Rodman?" The Jerusalem Post, July 3. Available at http://www.jpost.com/International/ Shurat-HaDin-vs-former-NBA-star-Dennis-Rodman

Brzeski, Patrick. 2013. "Psy Sets Rodman Straight: 'I'm from the South, Man!” The Hollywood Reporter, February 27. http://www.hollywoodreporter.com/news/ dennis-rodman-korea-psy-sets-424829

Begley, Louis. 2009. Why the Dreyfus Affair Matters. New Haven: Yale University Press.

Benda, Julien. 2007. The Treason of the Intellectuals. Trans. Richard Aldington. New Brunswisk: Transaction.

Brady, Tara. 2013. "In True North Korean Fashion, Women are 'Encouraged' to Choose from 18 Official Sanctioned Hairstyles (and Men Only Get 10!)." Mail Online, February 21. http://www.dailymail.co.uk/news/article-2282134/ North-Korean-fashion-women-encouraged-choose-18-officially-sanctionedhairstyles.html

Bourdieu, Pierre. 1993. The Field of Cultural Production: Essays on Art and Literature. Trans. Randall Johnson. New York: Columbia University Press.

Bourdieu, Pierre. 1986. “The Forms of Capital." In Handbook for the Theory and Research for the Sociology of Education, ed. J. Richardson, 241-58. Westport: Greenwood.

CBS. 2013a. "Photo: Kim Jong Un Wearing a Dennis Rodman Jersey," February 27. http://chicago.cbslocal.com/2013/02/27/photo-kim-jong-un-wearing-adennis-rodman-jersey/ 
CBS. 2013b. This Morning (March 6). https://www.youtube.com/watch?v= WtfFHUbJZsc

Coser, Lewis A. 1965. Men of Ideas: A Sociologist's View. New York: Simon and Schuster.

Cooper, Andrew S. 2013. "Where Diplomats Fear to Tread." The New York Times, March 17. http://www.nytimes.com/roomfordebate/2013/03/17/do-celebrityambassadors-like-dennis-rodman-make-a-difference/dennis-rodman-wherediplomats-fear-to-tread

Cotkin, George. 1997. "The Tragic Predicament: Post-War American Intellectuals, Acceptance, and Mass Culture." In Intellectuals in Politics: From the Dreyfus Affair to Salman Rushdie, ed. Jeremy Jennings and Tony Kemp-Welch, 248-70. London: Routledge.

Davidson, Ian. Voltaire: A Life. London: Profile.

Deleuze, Gilles and Félix Guattari. 1972. L'Anti-Oedipe. Paris: Editions de Minuit. Derfler, Leslie. 2002. The Dreyfus Affair. Westport: Greenwood.

Deventer, Kathrine, et. al. 2013. "New Narrative for Europe: The Body and Mind of Europe." http.//ec europaen/debate-future-europe/new-narrative/pdf/declaration_en pdf

Dewey, Caitlin. 2013. "State Department: No Position on Dennis Rodman's North Korea Trip." The Washington Post, March 1. http://www.washingtonpost.com/ blogs/worldviews/wp/2013/03/01/state-department-no-position-on-dennisrodmans-north-korea-trip/

Economist Intelligence United. 2012. Democracy Index 2012: Democracy at a Standstill. https://portoncvgovcv/dhub/porton por_globalopen_file?p_doc_id=1034

ESPN. 2013. First Take (May 29).https.//www youtube com/watch? $\mathrm{v}=\mathrm{Q} / \mathrm{iKOachKM}$

Falk, Barbara. 2003. The Dilemmas of Dissidence in the Eastern-Central Europe: Citizen Intellectuals and Philosopher Kings. Budapest: Central European University Press.

Fisher, Max. 2013. "Dennis Rodman Returning to N. Korea to Free Kenneth Bae: Could it Actually Work?" The Washington Post, May 10. http//wwwwwashingtonpost.com/blogs/worldviews/wp/2013/05/10/dennis-rodman-returning-ton-korea-to-free-kenneth-bae-could-it-actually-work $/$

Foucault, Michel. 1994. The Order of Things. New York: Vintage.

Foucault, Michel. 1980. “Truth and Power." In Power/Knowledge: Selected Interview \& Other Writings 1972-1977, ed. Colin Gordon, 109-33. New York: Pantheon.

Foucault, Michel. 1979. Discipline and Punish. The Birth of the Prison. Trans. Alan Sheridan. New York: Vintage. 
French, Paul. 2015. "North Korea's Kim Jong-Un Consolidates Power with Execution of Key Official." Reuters, August 13. http://blogs.reuters.com/greatdebate/2015/08/13/what-one-more-execution-means-in-north-korea/

French, Paul. 2007. North Korea: The Paranoid Peninsula: A Modern History. London: Zed.

Frankfurter Allgemeime Zeitschrift. 2013. "Kim Jong-Un? 'Toller Typ,” March 1. http:/www faznet/aktuell/gesellschaft/ex-hasketballstar-rodman-in-nordkorea-kim-jong-un-toller-typ-12099901 html

Frontline. 2014. "Secret State of North Korea." Available at http://www.pbs.org/ wgbh/pages/frontline/secret-state-of-north-korea/

Gladstone, Rick. 2013. "Rodman not First Choice for North Korea Trip." The New York Times, May 29. http://www.nytimes.com/2013/05/30/world/asia/rodmanmade-north-korean-trip-after-jordan-said-no-hbo-show-says.html? smid= tw-nytsports\&seid=auto\& $r=2 \&$

Glucksmann, André. 1980. The Master Thinkers. Trans. Brian Pearce. New York: Harvester.

Goldhagen, Daniel. 1997. Hitler's Willing Executioners: Ordinary Germans and the Holocaust. New York: Vintage.

Gramsci, Antonio. 1971. Selections from the Prison Notebooks. Trans. Quentin Hoare. New York: International.

Grayling, A.C. 2004. Life, Sex, and Ideas: The Good Life without God. Oxford: Oxford University Press.

Halliwell, Martin. 2007. American Culture in the 1950s. Edinburgh: Edinburgh University Press.

Haruki, Wada. 2014. The Korean War: An International History. Lanham: Rowman \& Littlefield.

Heidegger, Martin. 2010. “'Only God Can Save Us': The Spiegel Interview (1966).” In Heidegger: The Man and Thinker, ed. Tom Sheehan, 45-68. New Brunswick: Transaction.

Hofstadter, Richard. 1963. Anti-Intellectualism in American Life. New York: Vintage.

Human Rights Watch. 2014. "World Report 2014: North Korea." http://www.hrw. org/world-report/2014/country-chapters/north-korea

Jacoby, Russell. 1999. The End of Utopia: Politics and Culture in an Age of Apathy. New York: Basic.

Jacoby, Russell. 1987. The Last Intellectuals: American Culture in the Age of Academe. New York: Basic. 
Judt, Tony. 2011. Past Imperfect: French Intellectuals 1944-1956. New York: New York University Press.

Kater, Michael H. 1999. The Twisted Muse: Musicians and their Music in the Third Reich. Oxford: Oxford University Press.

Kim, Jinwung. 2012. A History of Korea: From "Land of the Morning Calm" to States in Conflict. Bloomington: Indiana University Press.

Kosselleck, Reinhart. 2004. Futures Past: The Semantics of Historical Time. Trans. Keith Tribe. New York: Columbia University Press.

Kuhn, Thomas. 1962. The Structure of Scientific Revolutions. Chicago: University of Chicago Press.

Mannheim, Karl. 1968. Ideology and Utopia: An Introduction to the Sociology of Knowledge. Trans. Louis Wirth. London: Routledge and Kegan Paul.

Martin, Bill. 2000. The Radical Project: Sartrean Investigations. Lanham: Rowman \& Littlefield.

Marx, Karl and Friedrich Engels. 1993. The German Ideology: Part One with Selections from Parts Two and Three and Supplementary Texts. Ed. C.J. Arthur. New York: International.

Mazower, Mark. 2002. "Violence and the State in the Twentieth Century." The American Historical Review 107 (2): 1158-78.

Mesmer, Philippe. 2013. "Un Ex-Star de la NBA sur les parquets nord-coréens." Le Monde, February 28. http://www.lemonde.fr/cgi-bin/ACHATS/acheter. cgi?offre $=A R C H I V E S \&$ type_item $=A R T \_A R C H \_30 J \&$ \& 2 bjet_id $=1225083$ \&xtmc $=$ rodman $\& x+c r=18$

Müller, Jan-Werner. 2006. “Julian Benda’s Anti-Passionate Europe.” European Journal of Political Theory 5 (2): 125-37.

New York Times. 2013. “Timeline on North Korea's Nuclear Program,” August 6. http./www nytimes com/interactive/2013/02/05/world/asia/northkorea-timeline.html\#/\#time238 7085

Ozouf, Mona. 1989. "Voltaire." In A Critical Dictionary of the French Revolution, ed. François Furet and Mona Ozouf, 869-80. Cambridge, MA: Harvard University Press.

Park, Kung-Ae and Scott Snyder. 2013. North Korea in Transition: Politics, Economy, and Society. Lanham: Rowman \& Littlefield.

Plato. 1981. Five Dialogues: Euthyphro, Apology, Crito, Meno, Phaedo. Trans. G.M.A. Grube. Indianapolis: Hackett.

Popper, Karl. 1957. The Poverty of Historicism. London: Routledge and Kegan Paul.

Posner, Richard. 2001. Public Intellectuals: A Study of Decline. Cambridge, MA: Harvard University Press. 
Rockmore, Tom. 1992. On Heidegger's Philosophy and Nazism. Berkeley: University of California Press.

Rodman, Dennis. 1996. Bad as I Wanna Be. New York: Dell.

Rothman, Joshua. 2014. "Is Heidegger Contaminated by Nazism?" The New Yorker, April 28. at http://www.newyorker.com/books/page-turner/is-heideggercontaminated-by-nazism

Samuels, David. 2010. "Q\&A with Noam Chomsky." Tablet Magazine, November 12. http://www.tabletmag.com/jewish-news-and-politics/50260/qa-noam-chomsky

Sang-Hung, Choe and Martin Fackler. 2009. "North Korea’s Heir Apparent Remains a Mystery." The New York Times, June 14. http://www.nytimes. com/2009/06/15/world/asia/15kim html? ref=global-home\&_r=0.

Sartre, Jean-Paul. 1993a. "What is Writing?" In Essays in Existentialism, ed. Wade Baskin, 301-32. New York: Citadel.

Sartre, Jean-Paul. 1994b. “The Humanism of Existentialism." In Essays in Existentialism, ed. Wade Baskin, 31-62. New York: Citadel.

Schake, Kori. 2013. "Reckless Behavior is Not Diplomatic Behavior." The New York Times (March 17). http://www.nytimes.com/roomfordebate/2013/03/17/ do-celebrity-ambassadors-like-dennis-rodman-make-a-difference/dennisrodman-reckless-behavior-is-not-diplomatic

Schwarz, David. 2012. Culture and Power: The Sociology of Pierre Bourdieu. Chicago: The University of Chicago Press.

Shirakawa, Sam H. 1992. The Devil's Music Master: The Controversial Life and Career of Wilhelm Furtwängler. Oxford: Oxford University Press.

Spetalnick, Matt and Mark Hosenball. 2013. "Analysis: Meet North Korea’s New Kim: Same as the Old Kims?" The Times of India, April, 3 http://timesofindia. indiatimes.com/toierrorfound.cms?url=http://timesofindia.indiatimes.com/ world/rest-of-world/Meet-North-Koreas-new-Kim-same-as-the-old-Kims/ articleshow/19366093.cms

Suh, Jae-Jung, ed. 2013. Origins of North Korea's Juche: Colonialism, War, and Development. Lanham: Lexington.

Tetteroo, Peter and Raymond Feddema. 2001. "Welcome to North Korea." The Netherlands: KRO Dutch Television.

Vasey, C.M. 2006. Nazi Ideology. Lanham: Hamilton.

Vice. 2013. "The Hermit Kingdom." https:/wwwwyoutube.com/watch?v= $\mathrm{IrCOh}$ usdzE

Vice. 2008. "The Vice Guide to North Korea." http://www.vice.com/video/viceguide-to-north-korea-1-of-3 
Voltaire. 1977. "Philosophical Dictionary." In The Portable Voltaire, ed. Ben Ray Redmond, 53-228. New York: Penguin.

Winock, Michel. 1997. Siècle des Intellectuels. Paris: Seuil.

Žižek, Slavoj. 2008. "Intellectuals, not Gadflies." Critical Inquiry 34 (s2): s21-s35.

Zola, Émil. 1998. The Dreyfus Affair: "J'Accuse" and Other Writings. Ed. Alain Pagès. New Haven: Yale University Press.

Zuckerman, Hariette. 1996. Scientific Elite: Nobel Laureates in the United States.

New Brunswick: Transaction. 


\title{
Jean-Paul Sartre and the Post-1968 Ethic of Anti-Representationalism
}

\begin{abstract}
In this article, I examine Jean-Paul Sartre's later thought in relation to the advent of post-structuralism, and, in particular, the avowed refusal of representational practices by its proponents. I argue that this refusal, most persuasively presented as the principle or ethic of anti-representationalism by Todd May, is, in fact, reflected in Sartre's move from committed writing and active social engagement to manifestly apolitical concerns. Reading Sartre's later work in light of this principle permits seeing these apparently purely intellectual concerns as part of an effort to come to terms with the ethical problematics of representation.
\end{abstract}

Around the time of the publication of his autobiography The Words in 1963, Jean-Paul Sartre began to withdraw from his well-known doctrine of committed literature as an effective means to social change and, more broadly, to view intellectual activity as politically irrelevant. His growing disillusionment regarding the effect of his own writing has been seen by many commentators, as well as by his own admission, as having led him temporarily to a more direct (and insistently practical as opposed to "intellectual") engagement in political activity. My interest here is to examine Sartre's struggles with the impact and significance of intellectual work-and writing specifically - in light of the advent of post-structuralism and post-structuralist politics. Although the abandonment of the idea of committed literature as a medium joining "man to man" in favour of the opposing extreme of viewing intellectual activity as an impediment to the realization of change has been criticized as part of his retreat to purely personal and private considerations, it also echoes some arguments central to post-structuralism. The core question I seek to ask here is why Sartre after 1968 increasingly took the stand of denying the intellectual the position of a (re)presenter and (re)describer addressing social and political controversies. The answer to this question is, in my opinion, to be found by linking Sartre's focus on his unfinished study of Gustave Flaubert to reassessments of the implications of a post-structuralist ethic of anti-representationalism. From this point of view, it is possible to conceive of Sartre's various turns as part of an overall attempt to harmonize practices of social responsibility with the problematics of understanding and meaning. Following this reading, Sartre's views of representation arguably anticipate many of the ideas defending the claim that, far from leading to a pluralism of values, post-structuralism allows for an ethics (and perhaps more importantly, also the practice) of intervention and dissent. 
In this context, the notion of "dissent" operates on a number of levels. First, I rehearse what I argue is both a post-structuralist and an existentialist theory of dissent: a breaking with the ideology of representation and representational violence combined with a formulation of an oppositional politics based on undecidability and choice. I see this as a "politics of dissent." After clarifying this, I will attempt to provide brief accounts of the core philosophical obstacles to social action faced by both existentialism and post-structuralism. I will also look at some of the different routes to intellectual and political dissent that Sartre attempted in order to resolve his personal desire for social engagement. Finally, I attempt to offer a dissenting reinterpretation of Sartre's intellectual trajectory and the role in it of his biography of Flaubert, The Family Idiot (1971-72). Here, I would like to argue that this text is Sartre's attempt to answer the problem of how representational violence could be overcome in writing.

\section{Identifying an Ethics of Anti-Representationalism}

Assuming a general acquaintance with the thought of Sartre, I will begin by explaining the less familiar and perhaps even rather cryptic "ethic of anti-representationalism" that defines the title. This is particularly important since I have been persuaded into taking on a somewhat specific definition of these terms by what I see as a most convincing and useful reading of post-structuralism, that presented by the American political philosopher Todd May in his books The Political Philosophy of Poststructuralist Anarchism (1994) and The Moral Theory of Poststructuralism (1995). As the titles of May's books already reveal, his interest is in providing an (at least somewhat) overarching reading of post-structuralism as a philosophy, or as a cohesive moral, ethical and political attitude. Granted, definitions of post-structuralism are difficult-even with respect to agreeing on its central figures. However, from the point of view of an intellectual history or a political philosophy, this attempt is necessary. Here, I will not qualify the label of post-structuralism excessively, but will mostly follow the lead of May, who sees it as exemplified especially in the thinking of Michel Foucault, Jean-François Lyotard, and Gilles Deleuze; I will additionally, however, make some reference to Jacques Derrida, whose views to me better explain the motivation for resisting both reductive representation and prescriptive rules.

In attempting to show an ethical foundation for post-structuralism, May is understandably hesitant. He cautions that his interpretation is an imposition in that post-structuralist thinkers themselves often shy away from explicit moral reflection. At the same time, as he says, "the lack of a moral grounding for poststructuralist claims [has been seen] to be one of the most problematic areas of its 
thought" (May 1995, 6). As numerous critics have pointed out, the post-structuralist emphasis on radical difference, what has sometimes also been described as a "universalization of difference" (see e.g. Haber 1994), can be interpreted as leading to the inability to justify political critique since, in its affirmation of the equal value of all and any opinions, it consists of a rejection of established and abiding moral principles. According to this critique, and " $[\mathrm{b}] \mathrm{y}$ precluding all binding universal values, Foucault and Lyotard also preclude assessment of any discourse or practice as oppressive or dominating" (May 1995, 9).

Even though such dismissals on the grounds of the notorious "anything goes" thesis are common among critics of post-structuralism, post-structuralists themselves are generally reluctant to offer any corrective. According to the most vociferous critics, they in fact categorically fail to provide useful responses and simply reiterate that their stand places them beyond traditional forms of argument. In a more favourable reading, one could reject this characterization of the post-structuralist position as facile and instead direct such critics to reconsider Derrida's critique of the metaphysics of presence and his existential emphasis on undecidability and choice as a route to responsibility: to act "ethically," one has to first recognize that there are no rules that can ensure this and no entailments to be found in the way things are, and then, in the awareness of this fundamental undecidability, choose to act in a particular way for considered reasons (or in Sartrean lexicon: in situation). For my purposes here, as much as for the purpose of defining a dynamics of dissent, this overall view is taken as the more philosophically convincing. ${ }^{1}$ As Derrida explains the issue of responsibility:

A decision can only come into being in a space that exceeds the calculable program that would destroy all responsibility by transforming it into a programmable effect of determinate causes. There can be no moral or political responsibility without this trial and this passage by way of the undecidable. Even if a decision seems to take only a second and not to be preceded by any deliberation, it is structured by this experience and experiment of the undecidable. (Derrida 1988, 116)

May's particular affirmation of the presence of morality in post-structuralist thinking is undoubtedly related to these ideas of undecidability and choice, but his prime interest is to provide some principles for action, and in this fundamental

1 For an example of how the two sides fail to engage each other as well as for a good overview of some of the core issues, see the exchange between John Searle (1977) and Derrida (e.g., 1988, especially the "Afterword"). For elaborations of how a Derridean viewpoint can be developed into a more practical politics of dissent, see, e.g., Mouffe (2013) and Rancière (2010). 
respect his view conflicts with a forcefully Derridean reading. (Hence, I assume, his focus on Foucault, Lyotard, and Deleuze.) His approach offers, however, a strong defence of post-structuralism against the kinds of dismissive arguments that it has from time to time provoked-especially in North American debatestrying, as it were, to meet them on their chosen grounds of argumentation. Further, although one could read a philosophical conflict into existence here, his historical contextualization of the motivations for the post-structuralist ethic is illuminating. May's view of the presence of an ethic or a moral principle is founded on what he calls the "central lesson" of the events of May 1968. His thesis is that the 1968 uprisings brought about the realization that "people needed to speak publicly in the name of their own ... inevitably diverse ... interests." He further argues that this realization "became a cornerstone of French poststructuralist theory," presenting it in the form of what he calls the principle of anti-representationalism: namely, that "representing others to themselves-either in who they are or in what they want-ought, as much as possible, to be avoided" (May 1995, 13; see also May 1994). Now, while he also makes a point of distinguishing his position from Richard Rorty's-quite correctly noting that his employment of the term "anti-representationalism" is distinct from Rorty's epistemologically focused use of the word-May's argument for the avoidance of representation here certainly parallels Rorty's ethical (and arguably post-structuralist) position, according to which redescribing others to themselves constitutes the ultimate form of cruelty. ${ }^{2}$

Born in the context of 1968, post-structuralism is in May's reading historically committed to this kind of anti-representationalism, the refusal to represent others (as much as possible). Yet, importantly for his account, this "principle of antirepresentationalism, although informing the work of these thinkers, was, because of their rejection of moral discourse, never set forth and defended as such." This contributed to a confusion that has "subverted a moral defence of their position" (May 1995, 13). Put bluntly, May sees the move made by post-structuralists from the principle of anti-representationalism to a wholesale rejection of moral discourse as a mistake

2 As May emphasizes: "The antirepresentationalism in question is moral and has nothing to do with issues of semantic antirepresentationalism associated with philosophers such as Richard Rorty" (May 1995, 48). It needs to be noted, however, that Rorty's "postmodern pragmatism" or "neopragmatism" is not as far from post-structuralism as is sometimes claimed in these debates; for a discussion of the affinities between these positions, see, e.g., Mouffe (1996). Sartre's position on anti-representationalism of a semantic kind, the problem of truthful representation, as it were, is an equally interesting issue, but goes well beyond the scope of my discussion here. For an excellent and accessible introduction to Rorty's thinking, see the selected essays in Rorty (1999). 
based on conflating morals founded in social practice with transcendent values. Stated differently, the "slippage" from the refusal to misuse power in telling people "who they are" to a more sweeping refusal of "practices of prescription" caused this rejection of moral discourse (May 1995, 14). If one were to follow Derrida's view more closely, this refusal could not, of course, be presented simply as a mistake or a slippage, since representation and moral prescription are part-and-parcel of the kind of violence that Derrida thinks should be resisted. ${ }^{3}$ Instead of seeing the post-structuralist universalization of difference as preventing the judgement of some particular position as "oppressive and dominating," as May has it, one could, from this perspective, simply judge all of them to be so.

Still, the central point of May's argument is to demonstrate that although post-structuralism is often viewed as a nihilistic defence of extreme relativism, especially by many Anglo-American critics, it also involves a moral dimension through its commitment to anti-representationalism. If we were to decide to accept the principle as well as the distinctions it makes between the spheres of doing and being, we could then legitimately discuss what people should $d o$, but would still not attempt to offer limiting definitions of who they are. Clearly, distinguishing in this way between "what others ought to [do] and what we would like them to be" (May 1995, 17) is important in the justification of the possibility of any prospective politics-perhaps especially those of dissent. Without it, we would be unable to say anything about people's actions without also stepping on the toes of their self-identifications. Then, without the right to judge something as being either "good" or "bad," we would have no means of privileging those behaviours and social practices that attempt to reduce oppression.

Some potential problems have to be admitted here. Importantly, the central distinction between holding moral principles and making practical judgements is easy to miss in this domestication of post-structuralist politics. Strictly speaking, there is never justification for making general pronouncements or valuations that extend beyond some particular practical situation. This is something that May (like many others in the Anglo-American debates) seems quite readily to ignore and underplay. Furthermore, the distinction between representing others in what they do and who they are is never clear-cut. Of course, May himself also notes some of these difficulties and acknowledges that moral values cannot be formulated without to an extent violating the principle of anti-representationalism. Yet,

3 For an excellent summary of the overall representational problematic in relation to Derrida's explication of violence, see Jenkins (2009), “'Nobody does it better," $255 \mathrm{ff}$.; cf. Derrida (1988). 
even where May's argument necessarily simplifies the philosophical problematics, this kind of shorthand for post-structuralism as a movement appears to be expedient for setting out its political drive and core strategy. In an approximation of a coherent post-structuralist political position, May argues that: "Roughly, the claim is that the consequences of what we might call representationalist practices are morally suspect, and thus that those practices ought to be abandoned" (May 1995,57 ). He further brings to this the (quite pragmatic) caveat that there may be good reasons for engaging in representation. For example, post-structuralist analyses of power relations (like Foucault's) intend to reveal oppressive practices. Thus the representations of victims in these cases are important and justified "as tools to be used ... in overcoming that oppression" (May 1994, 96). ${ }^{4}$

On this fundamental level, the post-structuralist effort decidedly resembles the Sartrean one: its main intention is to base ethical thinking in daily life-or, to reiterate the Sartrean terminology, in the individual's situation-rather than to construct it through appeals to transcendent values (cf. May 1995, 10). Suffice it to say that what thus in fact makes anti-representationalism an ethic is its recognition that even while we should, theoretically, be free to think of ourselves as we will, we do, in practice and as situated beings, have interactions with and even obligations to other people that can - and indeed must-be subject to some form of evaluation. ${ }^{5}$ This realization marks, in my view, a crucial break between theory and practice in both post-structuralism and existentialism. It boils down to the issue of choice. With reference to Derrida, again, but also to Sartre's definitions of existentialism: we can only ever make choices and decisions responsibly after first acknowledging the reality of undecidability. Theories (or values, rules, standards or principles) cannot justify ignoring that moment of aporia. In that spirit, and even when we agree that in theory representation is problematic and should be avoided, there are situations in which sitting back, resorting to silence or focusing on difference and dissensus alone is not enough and in which engaging in representation becomes the only (responsible) choice.

4 In conversation with Foucault, Deleuze has famously remarked that Foucault was "the first ... to teach us something absolutely fundamental: the indignity of speaking for others" (Deleuze 1977, 209; see also May 1994, 97).

5 This sentiment is echoed in Richard Rorty's firm separation of private and public spheres. For more on this question in both Rorty and Sartre, see Pihlainen 2001. 


\section{Obstacles to Playing Well with Others}

At the heart of the post-structuralist dilemma concerning representation as well as (an at least somehow unified and principled) oppositional politics and action is the relation of language to reality-particularly the post-structuralists' rejection of the old problematic of deriving values and guidance from "objective" reality. For Shadia B. Drury $(1994,204)$, the political alternatives provided by post-structuralism (or, for her, "postmodernism") consist of either a project of "reinvesting the meaningless world with meaning" or "a playful resignation" through which all actions become meaningless. As I understand this, the former encompasses efforts towards political commitment of the sort exemplified, for instance, by Rorty's pragmatic liberalism or even Foucault's questioning of power, whereas the latter lines up with a decidedly American, "Yale School" or "deconstructivist" reading of post-structuralism as a free play of meaning. ${ }^{6}$ In Drury's $(1994,205)$ interpretation, this suggests that "we can regard postmodern politics as a dispute between the right- and left-wing disciples of Nietzsche. The Right Nietzscheans are eager to construct the imaginary edifices that account for order and dominion, while the Left Nietzscheans are eager to defy, transgress, and unmask these fictitious edifices of power."

That division seems too easy, however. To me, it is based on an unjustified assumption that theory and practice or action should necessarily go hand-in-hand. Thinking, instead, in terms of a "resignation" regarding the capacity of theory to prescribe and the simultaneous practical decision to construct and impose meaning regardless would, I think, leave us better equipped to pursue an oppositional politics. Indeed, this appears to be something that Drury also partly settles on, albeit less explicitly. For her "Right Nietzscheans" at least,

the fact that political reality is an arbitrary construction of power is no reason to embark on a deconstructive project of genealogical unmasking. This could only lead to rabblerousing, mayhem, and barbarism. Instead, philosophy must use all the rhetorical powers at its disposal in order to restore the fragile fabric of myths and illusions on which political order depends. (Drury 1994, 207)

Rorty's often-criticized efforts to separate the private creativity of his so-called strong poets from the public morality of the liberal utopia he envisions would thus seem to be the perfect example of this "Right Nietzschean" attitude. And it might go some way toward defining what the situations are in which the principle of

6 Cf. Derrida’s criticism of this latter attitude in Derrida (1988, $115 \mathrm{ff}$.$) .$ 
anti-representationalism can justifiably be transgressed; if, that is, one subscribes to his professed liberal politics. But the dynamics offered by Drury here do not convincingly cover the thinking of those that she posits as "Left Nietzscheans." Rather, attempts to construct political order "from above" in this way run counter to the idea of any universal subjective assumption of responsibility and undermine the importance of choosing, on which any properly oppositional politics would inevitably need to rest. In this, there seems to be a deep-seated fear of a democratic or universal scepticism (a scepticism or recognition of undecidability for everyone, as it were) on the "Right," in distinction to the kind of advocacy of it that one might attribute to those on the "Left."

This same overall problem of the uncertainty of language and interpretations vis-à-vis reality is present in Sartre's thought, albeit at first on a much more immediate and personal level. In his Critique of Dialectical Reason (orig. 1960), Sartre presents the idea that " $[\mathrm{w}]$ ords are matter... They carry the projects of the Other into me and they carry my own projects into the Other" (Sartre 1991, 98). In other words, the processes of oppression and colonization that take place in the representation of others as historical or oppositional political groups, for example, also appear on this immediate intersubjective level. Sartre views the alienation produced by the relation of this "worked matter" to the human beings who work it as pervading all human actions to the extent that, as he revealingly says, "the meanings of the very words in my mouth are changed by others" (Sartre 1991, 98).?

While this view of language is much more involved than many of Sartre's earlier positions (and particularly so in relation to the idea of engagement in What is Literature?), it is continuous with his negative view of intersubjective relations. At its most basic, Sartre's thinking is that identity-or what he presents in its extreme form as a (self-)totalization realized through becoming "in-itself-for-itself"-is, for human beings, always an unattainable goal. The other's capacity to envision ends independent of my existence is what constitutes him or her as a subject, and that free subjectivity presents a threat to my freedom. To summarize this general existential plight: we are aware that we cannot achieve any permanent self-representation while also being afraid that others will be the ones to define us. On this view, human existence is based on the need to find recognition of

7 As Cary Wolfe $(1991,79)$ notes, language is, for Sartre at this later stage of his thinking, "the supreme example of those institutions, norms, and conventions which are the 'congealed' praxis of others and which mitigate against the subject's own freedom and praxis." Wolfe also offers a useful discussion of the contradictions in Sartre's conceptualization of language here. 
one's no-thingness, or, in Sartrean terms, of oneself as a for-itself (roughly, as a free subject) rather than an in-itself (a thing). ${ }^{8}$

Following up on the formulations in Sartre's Being and Nothingness (orig. 1943), Drury argues that, in accordance with this vision, the only way to achieve some experience of freedom is "to reduce the other to a thing before one is reduced to a thing by the other." In this spirit: "To live as a thing, to live for another and as the other expects is to live unauthentically [sic] or in bad faith" (Drury 1994, 26). In such a basic Kojèvean formulation of the Sartrean "look" or "gaze", the other becomes merely a means for gaining recognition and power. 9 This mutual hostility that Sartre seems to perceive as a necessary element of human interaction need not, however, be seen as defining all of his political or even representational commitments; the idea of objectifying others in order to satisfy one's desire for recognition certainly conflicts with Sartre's practical attempts to formulate a revolutionary politics for the oppressed. As is commonly argued, that specific political content was, however, to appear in Sartre's thinking and actions only after the Second World War.

8 This fundamental dynamic is an interesting correlative to Foucault's example of prisons that May (1995, 6-7) uses in his argument. The penal system has, according to Foucault, the effect of transforming a "doer of wrong" into a "criminal personality." Following Sartre's argument, this type of objectification can be seen as both unavoidable and detrimental to the freedom and authenticity of the subject. There is also a parallel limit to any "freeplay" in post-structuralism, even if it is sometimes ignored. As Honi Fern Haber explains with respect to Rorty: "The poststructural description of language along with its insistence on the play of signification informs Rorty's perspectivism. He sees the self as always being open to redescription and so as being a work of art. With this in mind he describes the best functioning human being as one who constructs her or his life out of her or his own narratives. But here Rorty has ignored a fundamental tenet of post-structuralism, i.e., that the tools of self-construction are always culturally inscribed-vocabularies are mirrors as well as tools-and that therefore, the self is never its own construction if by such a construction one has in mind the Romantic notion of the idiosyncratic genius whose creation is freed from the exigencies of the everyday. Such a view of artworks overlooks a fundamental political fact, a fact consistent with the demands of post-structuralism: insofar as it is a carrier of cultural signification (and is itself a cultural signifier) artworks [sic] always have a political component, though the political signification of an artwork may be more or less immediate and important" (Haber 1994, 74).

9 The Kojèvean "desire for recognition" that Drury elaborates on here also leads to attempts to dominate others whose conceptions one becomes dependent on. In desiring to become a "true" subject, one again, in effect, simply becomes an object for the valuation of the other. 
Although the view of conflict between individuals is perhaps at its most extreme in Being and Nothingness, it is present in some form in most of Sartre's writing - as indeed in the example from the Critique of Dialectical Reason already given - and is often the point of view that is assumed in examinations of all aspects of his thought. Later on in life, however, Sartre also attempted to give different interpretations of the problem. Thus, in the Critique, for example, his emphasis is on how "[w]e are united by the fact that we all live in a world which is determined by scarcity." (Sartre 1991, 136) And, crucially, this scarcity can lead to collective efforts at overcoming it. Indeed, Sartre even goes so far as to argue that, through collective (political) action, a world where the intersubjective struggle is no longer necessary could in fact be achievable. Where transcending scarcity is, here, then, "man's fundamental project" - and, important to note, a project that Sartre at times suggests may even lead to the formulation of a more generally sustainable ethics, an ontological ethics-there still remains, for Sartre as for so many of his contemporaries, an innate conflict between an individual's aspiration to transcendent freedom and his or her having a tolerant attitude toward the other. ${ }^{10}$

\section{Sartre's Conversion to Politics: Literature as a Means to Liberation}

As David Detmer has argued in his Freedom as a Value (1988), the centrality of ontological freedom in Sartre's philosophical worldview ultimately suggests the question of political liberation as relevant too. For Sartre, ontological freedom is a result of engagement with the world. And, as he argues, the subject becomes conscious of his or her subjectivity only through negating the in-itself. (In order to bring this closer to the post-structuralist terms discussed above, this can also be presented as the inevitable need for people to impose meanings onto a meaningless world.) In this sense consciousness can, in Sartre's words (1976, 90; cf. also

10 To give some background to the operation of scarcity: still in the context of Sartre's argument for freedom, the use of the Hegelian master-slave dialectic is quite understandable since, for a human being to become "truly" human, he or she must meet the given conditions and, through an active negation, win or produce his or her freedom. In the Critique, Sartre introduces the fact of scarcity as an explanation for the historical development of this conflict. As long as scarcity exists, not everyone has the possibility of realizing their freedom. Put crudely, those who become "slaves" are those who are totally immersed in the struggle for making a living and cannot afford the luxury of fashioning a life. If the condition itself could be overcome, then and only then, could the conflict be left behind-and this possibility is what introduces the need for politics. 
Aronson 1980, 73), "exist only as engaged in this being which surrounds it on all sides and which paralyses it with its phantom presence." Because this "being" otherwise paralyses consciousness, its negation is the only route to self-creation and freedom. Extending this same dynamic to the level of the intersubjective, it is easy to see where the political impulse comes in: since all humans are intrinsically free, they should have the opportunities for realizing that freedom in practice.

Sartre's indifference to social and political questions, as displayed by the almost exclusive focus on the ontological in his early work, has commonly been read as marking a broad disinterest in public issues in the period before the Second World War (e.g. Dobson 1993, 17). In contrast to this early apolitical and purely philosophical stance, biographical accounts often posit that a change took place during the war. According to this view, after 1941, and arguably influenced by his experiences of collectivity as a prisoner of war, Sartre's quest became one of integrating the socio-political to his earlier obsession with the experience of the individual. As a result, for Andrew Dobson, Sartre-the "apolitical litterateur"now became, for the first time, properly involved in a political project. Or, similarly, in the words of Sartre's biographer Annie Cohen-Solal, he finally "started looking at the world as though he were an actor in it." (Cohen-Solal 1987, 125; cf. Dobson 1993, 18) Looking back on his life in 1977, Sartre also himself admitted to having been overly saturated by "bourgeois individualism" before the war. In his own words: "I was completely wrong ... not to have become more closely involved in political matters, I mean involved on a practical level, but it was difficult." (Dobson 1993, 18)

Ronald Aronson $(1980,111)$ compellingly describes this newfound attitude in terms of action and engagement; from his view, "Sartre was determined to act." Against this overall background, Sartre's turn to questions of "history, 'reciprocity', and emancipation" (Dobson 1993, 20) can quite confidently be read as politically motivated. In this move to become more politically involved, Sartre first formulated his well-known (if highly contested) conceptions of committed literature and engagement in What is Literature? (originally published in 1948). It can quite usefully, I think, be said that the idea of commitment here represents a move from an interest in "mere" consciousness to conscience, insofar as in this political formulation the "authenticity" of the writer can exist only through an engagement with a world that he or she feels needs to be transformed. ${ }^{11}$

11 This notion of cōnscientia is interesting here since it brings together various aspects of "truth" and knowledge-indeed implying the quite common idea that there is some kind of continuum or entailment from factual knowing (and proceeding though feeling and consciousness) to an ethical awareness of right and wrong. 
Sartre's core idea in employing literature in this political move rests on his conception of the relationship of the writer to the reader. The relationship between them is, in his argument, ideal in that it cannot sustain objectification. As a given, the reader must approach a literary work with an attitude of "free, selfdetermining creativity" (Aronson 1980, 149; for more on this, see also Pihlainen 2015). At the same time, there must be a generic commitment from the author to respect this freedom since the work cannot be re-created in the mind of the reader except in an atmosphere of mutual respect and equality. Recall here Sartre's observation that the words that a subject utters are beyond his or her control once they are heard by another. For them to have significance, the other must be free to attribute this significance to them. In this sense writing is, as he puts it, "by its very nature an act of confidence in the freedom of men" (Sartre 1949, 67). Hence, in committing themselves to the printed word, writers inevitably acknowledge the freedom of their readers.

\section{A Second Conversion: The Ineffectual Intellectual}

Sartre is often portrayed as having gradually become disillusioned by his political project of committed writing. Accordingly, he no longer in the 1960s viewed literature as a medium "that joins man to man," but instead saw it as an impediment to the practical realization of change. Indeed, by the time of his Japanese lectures in 1966, he is seen to have completely given up on the earlier "conception of prose as a practical instrument" (Aronson 1980, 310-311). Aronson, in fact, claims that these lectures indicate conclusively that now "[p]olitics and writing were becoming separate activities for Sartre" (Aronson 1980, 310). According to this interpretation, Sartre (again: "finally") gives up on the idea that literature can effect change. Consequently, he dismisses literature and finds commitment and any attempts to promote change to be viable only through direct political involvement. In light of the ties of his views as set out in What is Literature? to the long-term literary theory and representationalist aspects of his thinking, it would seem, however, that much of Sartre's life-work is unnecessarily undermined by conceiving of these changes in so simplistic a way.

Indeed, it seems to me that the post-structuralist insistence, as Eve Tavor Bannet $(1993,4)$ phrases it, that "'writerly texts' can be used to change the discursive and social texts we are reproducing and to fashion a 'new politics of truth"' is based on reasoning quite similar to that employed by Sartre. On this point, the crucial difference between Sartre's view and that of the post-structuralists would seem to be mostly in the extent to which they allow for political commitment in literary texts. Sartre's committed literature is, after all, easily seen as tending toward 
propaganda-despite his explicit refusal of that position. In this quite idealistic view, there would at least be no room for the wrong kind of propaganda: "It would be inconceivable that this unleashing of generosity provoked by the writer could be used to authorize an injustice, and that the reader could enjoy his freedom while reading a work which approves or accepts or simply abstains from condemning the subjection of man by man" (Sartre 1949, 67).

Although this is something that needs to be examined further, I would venture to claim that overt political commitments as demanded by Sartre at this stage of engagement would preclude the "writerliness" of texts for many post-structuralists at least, especially so since their defence or "universalization" of difference is often seen as leading to an incapacity to defend particular political positions over others. In this understanding, the core of a "writerly" or "worklike" text can arguably be seen to rest in its refusal to offer up meaning, instead leaving room for the reader to impose it as part of an experiential reading process. ${ }^{12}$ In this scenario, overt political intentions (indeed all authorial intentions) are left out of the textual equation.

\section{Sartre's Flaubert as a Retreat from Political Involvement}

The interpretation of Sartre's move from the intellectual's stance of committed writing to direct political activity is most forcefully presented by Aronson, who sees Sartre as advocating an anti-intellectualism of intellectuals, in which the only benefit of being an intellectual is to be found in the political "clout" that such a social position affords. Indeed, Aronson $(1980,321)$ portrays Sartre as arguing that "[o]ur ideas are irrelevant to political action; we must seek to create situations in which the masses can experience their own ideas." If this isn't the principle of anti-representationalism translated into practice, then what is?

Alongside this effort to avoid describing the masses on their behalf, which seems to align so well with the general political demands emerging at the time, Sartre's work on the enormous study of Gustave Flaubert (The Family Idiot, or more familiarly, "The Flaubert," which was published in 1971 and 1972) has often been explained as, at least to an extent, a counter-tendency, a withdrawal once again to the private deliberations of the intellectual. Indeed, in later interviews, Sartre gives support to this interpretation. Commenting on the Flaubert, Aronson

12 For an especially illuminating examination of this kind of text as envisioned by Foucault in the early part of his career, see Timothy O'Leary's Foucault and Fiction (2009). 
(1980, 303; also see de Beauvoir 1985, 5-7) further notes that it was in fact "a significant departure from the main line of Sartre's life's work. In it, he no longer took his pen for a sword. He sought not to move or to change his audience, but only to understand a single human being, Gustave Flaubert." Flaubert being-it should be noted-like Sartre, a petit bourgeois intellectual.

This portrayal of a new anti-intellectual Sartre, who, after May 1968, "plunges" into a "serve-the-people" activism" (Aronson 1980, 323-324) but simultaneously continued to pursue a private, apolitical autobiographical project (which incidentally came to represent a full quarter of his collected works) has been questioned by, among others, Dobson, who claims that the Flaubert was a necessary, and a very significant, continuation of Sartre's developing theory of history (Dobson 1993; cf. Flynn 1997). While that may be so, my interest here is not in revealing such a theory of history, but in arguing instead for an evolving theory of representation in tune with the anti-representationalist ethic. Dobson, to me quite correctly, argues that the Flaubert represents an extension of Sartre's attempts at discovering a method for writing history, and, at the same time, a more detailed investigation of the dialectical workings in the relationship between individuals and their situation-one obvious concern also being to illustrate the "encounter" between individual traits and "given" conditions. What I think he does not emphasize enough, however, is the importance of the Flaubert as an attempt to understand another human being (albeit a dead one) as somehow an authentic subject, without, in other words, submitting them to the usual violence of representation.

In terms of both a theory of history (or more properly a philosophy of history, a view of history as movement) and the problematics of representation, it is useful to note that Sartre follows Hegel in attempting to reconcile the universal with the individual through the movement of the dialectic. For Sartre, however, this unfolding of the dialectic is not conceived of in terms of any Spirit but of human agency. Thus he sees all individual and creative efforts as necessarily pitted against the already "worked matter" of social, cultural, and material conditions, being integrated into them, and ultimately also becoming similarly resistant to an individual's agency or desires. The totalization of history that Sartre proposes is thus the effect of human actions, free actions carried out in the confines of the practico-inert: in other words, within the conditions for history itself. While he does not manage to demonstrate how this totalization can result in a single history or history as some kind of movement, as he seems to propose in the Critique, the emphasis on actions in situation can be understood in relation to his take on the idea of "the end of history." According to Drury $(1994,76)$, Sartre's conception of the dialectic 
crucially differs from the Hegelianism of Kojéve in that it refuses to admit that history is capable of ending; Sartre instead sees the struggle as unwinnable and the satisfaction of need as a never-ending quest.

This difference regarding the significance of the historical dimension marks the change in Sartre's thinking that many commentators attribute to his taking up the Marxist cause (see e.g., Dobson 1993). Drury (1994, 76), however, explains this in another way. She goes on to say that "Sartre chose to become a Marxist for the sake of the revolutionary struggle itself. He had absolutely no hope that the revolution would succeed in attaining its goals." Her argument aims at making the more general point that "it is the fight or the struggle itself that makes us human." Thus: "Every human encounter is an attempt by one party to reduce the other to an object or thing and the one who is so reduced must struggle to be other than what he is defined to be." Hers is, however, a very Kojèvean reading of Sartre to the extent that it focuses on the conflict as such and neglects the reality of scarcity that Sartre sees at its origin. If we were to agree to this reading of the master-slave dialectic as a defining constant of the human condition and, as such, a dynamic of history writ large, it might be difficult to see Sartre as primarily focused on an ethics of anti-representationalism. If, however, we keep in mind his interest in writing and his emphasis on situated actions, the issue of representation seems to remain his core problematic.

\section{Or, the Flaubert as an Attempt to Overcome Objectification in Representation}

In light of both the epistemological and ethical issues that the principle of antirepresentationalism and, indeed, the overall critique of representation in contemporary continental philosophy seek to address, it would seem safe to say that an individual's life cannot be depicted "authentically" (and I intend this "authenticity" in two senses: that is, with regard to both truthfulness and subjectness).

Epistemologically, such an attempt is always destined to fail. The narrative practice of the filling in of blanks not covered by the evidence, the questions of beginning and end points, the use of explanatory modes, tropes or emplotments, and indeed, in general, the questions raised by the attempt to transform documentary evidence into a coherent and motivated narrative are hurdles that no "objective" view of representation can clear. Yet, and despite the fundamental nature of this problematic, Simone de Beauvoir tells us that Sartre wrote his biography of Flaubert with the express intention of proving "that any man is perfectly knowable so long as one uses the right method and possesses the necessary documents" (de Beauvoir 1985, 6; cf. Golomb 1995, 157). To grant this claim any credibility, the meaning of "knowability" needs to be extended to include the issue of the subject's 
subjectivity or "authenticity" somehow, but the problematic is almost the same: reducing a person, and hence an intentional life, to a description appears to entail objectification and (representational) violence in the extreme.

Jacob Golomb $(1005,18)$ formulates the mixed problematic for representations that might be expected to encourage and promote particular values and actions in the following way:

Arguing for authenticity is self-defeating in that it presupposes the authority of rationality and objectivity, which is called into question by this ideal. Since one cannot argue rationally for adopting authentic life, one must be satisfied with the subtle enticement of the reader. But how can someone be enticed into authenticity? Through descriptions of authentic lives? But how can an authentic subject or self be depicted?

What then are Sartre's strategies in the Flaubert? Looking at the 2800 close-printed pages of the uncompleted Flaubert, one is tempted to say that the key is that Sartre certainly did not aim at any reduction of his subject. Instead, his approach of historical, "psychological" or biographical investigation can indeed be read as an attempt to cover all aspects relevant to the subject in the fullness of the particular situation. In this way, the impact of reductive violence at least might conceivably be softened. But he also claimed that he was involved in "showing a method," and, according to de Beauvoir, it seems that this "method" was firmly based in the empirical: "His basic idea was that at no matter what point in history and whatever the social and political context, it was still essential to understand people and that his study of Flaubert might be of use to that end" (de Beauvoir 1985, 7).

At the same time, along with this process of detailed description, it is evident to a reader of The Family Idiot that Sartre examines Flaubert in a way quite similar to that utilized by a writer of fiction who has the advantage of being permitted to describe the hidden workings of the character's mind. ${ }^{13}$ The adoption of this strategy makes sense: such a vantage point would seem to be the only available one in the attempt to represent an authentic subject as subject. Some idea of inner workings is needed for a presentation of subjectivity. However, with reference to the fictionalization that such liberal use of the imagination necessarily introduces, it should be noted that what is in question is thus, strictly speaking, no longer a representation or re-construction but simply a construction-perhaps useful in relating to the historical past in various ways, but in no way definitive.

Before concluding, I want to tentatively raise the question of whether the consideration of truthfulness should be introduced into the representation of

13 For more on fictionality and other representational strategies utilized in The Family Idiot, see Aronson (1980, 337 ff.) and Pihlainen (2005). 
"authenticity" at all. Perhaps such representation should rather be assessed purely in the realm of the aesthetic. Much like Rorty, May, for instance, speaks of an "aesthetics of living" that can be separated from issues of public accountability. According to this view, there are endless aspects of living and choices of lifestyle that do not require or even admit definition or moral assessments. Certainly, the question of a subject's authenticity in the sense of his or her being "for-itself" or holding to some "fundamental project" is not a matter to be evaluated by reference to abstract moral criteria. What is more, since such authenticity is always in situation, it should, if we are to read Sartre as consequent on this, perhaps ultimately not be represented as something merely existing but rather as a continuous becoming. That is to say that, since the subject affirms his or her authenticity in each action, the representation of an authentic subject cannot be undertaken as a whole but should instead unfold in the presentation of each action in and reaction to the world. The strategies by which this can be done in writing are limited, however, because the imposition of some comprehensive "meaning" is so commonly expected by readers. Complex and confusing texts that take "writerliness" to such extremes are the exception - even if their complexity is realized primarily through detail and volume, as in the Flaubert.

While Sartre does attempt to describe the fragmentary elements making up the life of Flaubert as constituting-or rather, being brought together by-a single "life project," his effort to understand Flaubert is also based on the attempt to find the sense of Flaubert's self-understanding. The subject should thus (hypothetically in this particular case) be able to identify with a successful representation. Here, the question of "writerly" or experiential texts certainly comes into its own, whether with respect to the "subject" of the representation or to readers more generally: the kind of imaginative identification and engagement of subjective processes of meaning-construction that experiential texts can facilitate is crucial to keeping representations from overstepping their boundaries with regard to objectification and presumptuous appropriations.

\section{Conclusion}

Comparisons between Sartre and the post-structuralists have been attempted before. Yet Dobson for one has firmly denied any similarities and instead argues that Sartre "stands firmly opposed to the post-structuralist tendencies that were emerging as he entered the final phases of his productive life" (Dobson 1993, 184-185; for other readings of the relation between Sartre and post-structuralism, see e.g., Howells 1988 and Fox 2003). Despite this popular view, I hope to have demonstrated that-like the post-structuralists-Sartre at the very least had "learned 
the lesson" of representation, what May characterizes as the lesson of $1968 .{ }^{14}$ The effects of this lesson seem to be clearly visible in Sartre's political trajectory, and particularly in his disappointment with and opposition to representational practices already during the second half of the 1960s. In seeing these practices as oppressive, or at least in many situations redundant, he too denied himself-and intellectuals in general - the right to speak for others.

By examining the various strategies that Sartre adopted in his work to tackle the problems of social responsibility and representation, it can readily be seen that an avowed refusal to represent others does not always effectively lead to change; a cynic might even say that such a refusal can be viewed more as a private choice made to soothe one's conscience. Interpreted more positively, however, even Sartre's long-time "bourgeois" preoccupation with Flaubert, or at least the textual and interpretive strategies of The Family Idiot, can be viewed in terms of the overall challenge presented by representation: dissatisfied with simply casting off the role of the committed intellectual and immersing himself in political action, Sartre may be interpreted as having continued to search for an alternative means for tackling problems of oppressive and inadequate (textual) representation. Admittedly going further than many post-structuralist thinkers in meeting the problem, he attempted, on this view, to transcend the difficulty of representation in his Flaubert-Sartre's final effort to demonstrate that humans can, even in terms of their intentional lives, be responsibly knowable and communicable to and by others.

\section{References}

Aronson, Ronald. 1980. Jean-Paul Sartre: Philosophy in the World. London: Verso. Bannet, Eve Tavor. 1993. Postcultural Theory: Critical Theory after the Marxist Paradigm. London: Macmillan.

Cohen-Solal, Annie. 1987. Sartre: A Life. Translated by Anna Cancogni. New York: Pantheon Books.

De Beauvoir, Simone. 1985. Adieux: A Farewell to Sartre. Translated by Patrick O'Brian. London: Penguin Books.

Derrida, Jacques. 1988. Limited Inc. Evanston, IL: Northwestern University Press.

14 It also seems to me that-in popular readings-attention to structures and relations is too readily opposed to Sartre's existentialist emphasis on freedom (Sartre's focus on the importance of the "practico-inert" later on is largely ignored) and, similarly, that the post-structuralists' self-made claims to radically differ from their predecessors on views of subjectivity is taken on faith. 
Deleuze, Gilles. 1977. "Intellectuals and Power: A Conversation with Michel Foucault and Gilles Deleuze." In Language, Counter-Memory, Practice: Selected Essays and Interviews, ed. D.F. Bouchard, 205-217. Ithaca: Cornell University Press.

Detmer, David. 1988. Freedom as a Value: A Critique of the Ethical Theory of JeanPaul Sartre. La Salle, IL: Open Court.

Dobson, Andrew. 1993. Jean-Paul Sartre and the Politics of Reason: A Theory of History. Cambridge: Cambridge University Press.

Drury, Shadia B. 1994. Alexandre Kojève: The Roots of Postmodern Politics. New York: St. Martin's Press.

Flynn, Thomas R. 1997 Sartre, Foucault, and Historical Reason: Toward an Existentialist Theory of History, Volume 1. Chicago: University of Chicago Press.

Fox, Nik Farrell. 2003. The New Sartre: Explorations in Postmodernism. London: Continuum.

Golomb, Jacob. 1995. In Search of Authenticity: From Kierkegaard to Camus. London \& New York: Routledge.

Haber, Honi Fern. 1994. Beyond Postmodern Politics: Lyotard, Rorty, Foucault. London \& New York: Routledge.

Howells, Christina. 1988. Sartre: The Necessity of Freedom. Cambridge: Cambridge University Press.

Jenkins, Keith. 2009. At the Limits of History: Essays on Theory and Practice. London \& New York: Routledge.

May, Todd. 1994. The Political Philosophy of Poststructuralist Anarchism. University Park, PA: Pennsylvania State University Press.

May, Todd. 1995. The Moral Theory of Poststructuralism. University Park: Pennsylvania State University Press.

Mouffe, Chantal (ed.). 1996. Deconstruction and Pragmatism. London \& New York: Routledge.

Mouffe, Chantal. 2013. Agonistics: Thinking the World Politically. London \& New York: Verso.

O'Leary, Timothy. 2009. Foucault and Fiction: The Experience Book. London \& New York: Continuum.

Pihlainen, Kalle. 2001. "Crossing the Public-Private Divide: Jean-Paul Sartre and Richard Rorty on the Function of Literature." In The New Europe at the Crossroads: Europe's Classical Heritage in the Twenty-First Century, ed. Ursula E. Beitter, 281-299. New York: Peter Lang.

Pihlainen, Kalle. 2005. "Understanding and commitment: Narrative representation in Sartre's L'Idiot de la Famille." Clio 34(1-2): 59-82. 
Pihlainen, Kalle. Forthcoming, 2016. "Committed Writing: History and Narrative Communication Revisited." In Historians as Engaged Intellectuals, ed. Stefan Berger, pagination forthcoming. New York: Berghahn Books.

Rancière, Jacques. 2010. Dissensus: On Politics and Aesthetics. Ed. Steven Corcoran. London: Bloomsbury.

Rorty, Richard. 1999. Philosophy and Social Hope. London: Penguin Books.

Sartre, Jean-Paul. 1976 [1943]. Being and Nothingness: An Essay on Phenomenological Ontology. Trans. Hazel E. Barnes. London: Methuen \& Co.

Sartre, Jean-Paul. 1949 [1948]. What is Literature? Trans. Bernard Frechtman. New York: Philosophical Library.

Sartre, Jean-Paul. 1991 [1960/1985]. Critique of Dialectical Reason, Volume I, Theory of Practical Ensembles. Trans. Alan Sheridan-Smith, ed. Jonathan Rée. London \& New York: Verso.

Searle, John R. 1977. "Reiterating the Differences: A Reply to Derrida." Glyph 1: 198-208.

Wolfe, Cary. 1991. "Rethinking Commitment: Ontology, Genre, and Sartre's Mallarmé." Diacritics 21(4): 69-85. 


\section{Contributors}

Ben Dorfman (ed.) is associate professor of intellectual and cultural history at Aalborg University (Denmark). Ben writes and teaches on a range of issues in political and cultural history and theory and human rights. His forthcoming book is Opinions and Interventions: 13 Acts of Academic Journalism and Historical Commentary on Human Rights (Peter Lang).

Barbara J. Falk is associate professor in the Department of Defence Studies at the Canadian Forces College/Royal Military College of Canada, and is the author of The Dilemmas of Dissidences: Citizen Intellectuals and Philosopher Kings (Central European University Press, 2003). Her work broadly examines the persecution and prosecution of dissent, especially as a result of international conflict. She is currently writing a book on the 1949 trial of the CPUSA leaders in New York and the other Smith Act trials.

Janina Gosseye is a research fellow of the Methods and Analysis Research Group at TUDelft (The Netherlands) and of the Architecture Theory Criticism History Research Centre (ATCH) at the University of Queensland (Australia). Her research focuses the notion of collectivity in post-war architecture and is situated at the nexus of architectural theory and social and political history.

John Macarthur is a professor in and directs the ATCH (architecture, theory, criticism, history) Research Centre at the University of Queensland. He writes on intellectual history and his current project is on the aesthetics of architecture.

Barbara Martin is finishing a PhD on Soviet dissident historians of the Brezhnev era at the Graduate Institute of International and Development Studies in Geneva (Switzerland). She received an SNSF Doc.mobility scholarship for the research contributing to the paper in the current volume.

Kalle Pihlainen is adjunct professor of philosophy of history at the Department of Political Science and Contemporary History, University of Turku (Finland). His work focuses on the ethics and politics of historical representation, cultural theory, embodiment and existential phenomenology. He has published articles in numerous anthologies and journals including Rethinking History, New Literary History, Historein, Storia della Storiografia and Clio. His book The Work of History: Constructivism and a Politics of the Past is forthcoming from Routledge in 2015. 
Stephanie Sapiie is associate professor of political science at SUNY Nassau Community College (USA). She earned her doctorate in 2012 at the CUNY Graduate Center in New York City.

Verita Sriratana is a former recipient of the Anandamahidol Foundation Scholarship and the Slovak National Scholarship, is currently a lecturer in the Department of English at Chulalongkorn University (Thailand). Her first book Particular Modernity/Modernism: Locating Modernist Moments in Czech and Slovak Literature has been published by Comenius University in Bratislava (2015).

Bent Sørensen is associate professor of English at Aalborg University (Denmark). He teaches creative writing, American literature and cultural studies. He is President of the Foundation for the Psychological Study of the Arts. Recent work ranges from analyses of the Beats to aspects of American song lyrics.

Hasmet M. Uluorta is assistant professor of world politics and international development at Trent University in Peterborough, Canada, where he teaches courses in globalization, American politics and international relations. His research is concerned with global order and transformation. He is the author of The Social Economy: Working Alternatives in a Globalizing Era (Routledge, 2009). 